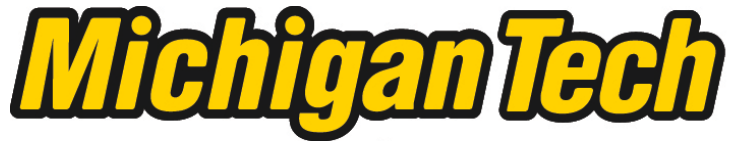 \\ Michigan Technological University Create the Future Digital Commons @ Michigan Tech
}

\section{Evolution of the Southern Kenya Rift from Miocene to present with a focus on the Magadi area}

Alexandria L. Guth

Michigan Technological University

Follow this and additional works at: https://digitalcommons.mtu.edu/etds

Part of the Geology Commons

Copyright 2007 Alexandria L. Guth

\section{Recommended Citation}

Guth, Alexandria L., "Evolution of the Southern Kenya Rift from Miocene to present with a focus on the Magadi area", Master's Thesis, Michigan Technological University, 2007.

https://doi.org/10.37099/mtu.dc.etds/321

Follow this and additional works at: https://digitalcommons.mtu.edu/etds

Part of the Geology Commons 


\title{
Evolution of the Southern Kenya Rift from Miocene to Present with a Focus on the Magadi Area
}

\author{
By \\ Alexandria L. Guth \\ A THESIS \\ submitted in partial fulfillment of the requirements \\ for the degree of \\ MASTER OF SCIENCE \\ Geology
}

MICHIGAN TECHNOLOGICAL UNIVERSITY

2007

Keywords: Geology, Geochronology, Remote Sensing, Mapping, Lake Magadi, Soda Lakes, Chert, Kenya Rift

Copyright (C) Alexandria L. Guth 
This thesis, "Evolution of the Southern Kenya Rift from Miocene to Present with a Focus on the Magadi Area" is hereby approved in partial fulfillment of the requirements for the degree of MASTER OF SCIENCE in the field of GEOLOGY

Department of Geological and Mining Engineering and Sciences

Thesis Advisor: James R. Wood

Department Chair: Wayne D. Pennington

Committee Members: William I. Rose, Ph.D.

William J. Gregg, Ph.D.

Susan T. Bagley, Ph.D.

Date: August 9, 2007 


\section{Abstract}

The Kenya (a.k.a., Gregory) Rift is a geologically active area located within the eastern branch of the larger East African Rift System (EARS). The study area is located in the southern Kenya Rift between $1^{\circ}$ South and the Kenya-Tanzania border (covering approximately 1.5 square degrees, semi-centered on Lake Magadi) and is predominantly filled with extrusive igneous rocks (mostly basalts, phonolites and trachytes) of Miocene age or younger. Sediments are thin, less than 1.5Ma, and are confined to small grabens. The EARS can serve both as an analogue for ancient continental rifting and as a modern laboratory to observe the geologic processes responsible for rifting.

This study demonstrates that vintage (as in older, quality maps published by the Kenya Geological Survey, that may be outdated based on newer findings) quarter-degree maps can be successfully combined with recently published data, and used to interpret satellite (mainly Landsat 7) images to produce versatile, updated digital maps. The study area has been remapped using this procedure and although it covers a large area, the mapping retains a quadrangle level of detail. Additionally, all geologic mapping elements (formations, faults, etc.) have been correlated across older map boundaries so that geologic units don't end artificially at degree boundaries within the study area. These elements have also been saved as individual digital files to facilitate future analysis. A series of maps showing the evolution of the southern Kenya rift from the Miocene to the present was created by combining the updated geologic map with age dates for geologic formations and fault displacements. Over 200 age dates covering the entire length of the Kenya Rift have been compiled for this study, and 6 paleo-maps were constructed to 
demonstrate the evolution of the area, starting with the eruption of the Kishalduga and Lisudwa melanephelinites onto the metamorphic basement around 15Ma. These eruptions occurred before the initial rift faulting and were followed by a massive eruption of phonolites between 13-10 Ma that covered most of the Kenya dome. This was followed by a period of relative quiescence, until the initial faulting defined the western boundary of the rift around 7Ma. The resulting graben was asymmetrical until corresponding faults to the east developed around 3Ma. The rift valley was flooded by basalts and trachytes between 3Ma and 700ka, after which the volcanic activity slowed to a near halt. Since 700ka most of the deposition has been comprised of sediments, mainly from lakes occupying the various basins in the area.

The main results of this study are, in addition to a detailed interpretation of the rift development, a new geologic map that correlates dozens of formations across old map boundaries and a compilation of over 300 age dates. Specific products include paleomaps, tables of fault timing and displacement, and volume estimates of volcanic formations. The study concludes with a generalization of the present environment at Magadi including discussions of lagoon chemistry, mantle gases in relation to the trona deposit, and biology of the hot springs.

Several biologic samples were collected during the 2006 field season in an attempt to characterize the organisms that are commonly seen in the present Lake Magadi environment. Samples were selected to represent the different, distinctive forms that are found in the hotsprings. Each sample had it own distinctive growth habit, and analysis showed that each was formed by a different cyanobacterial. Actual algae was rare in the collected samples, and represented by a few scattered diatoms. 


\section{Acknowledgements}

This project was made possible through various awards granted to Dr. Wood by the United States Department of Energy and the ACS Petroleum Research Fund.

I would like to thank my advisor Dr. Wood for providing me with this amazing research opportunity and for agreeing to hold our morning meetings at a nearby coffee shop. L. Kiema at the Magadi Soda Company deserves thanks for letting us borrow his copy of Baker's 1958 “Geology of the Magadi Area” map when we were unable to attain it otherwise, and for providing us with company core data from the lake. Anthony Mbuthia, another employee of the Magadi Soda Company, also deserves recognition for his help in the field as a guide around Magadi. The list of in-field help would not be complete without gratefully mentioning Billy Wanzala who was our driver every year in Kenya, showed amazing skill in navigating Nairobi traffic, and, most importantly, kept us safe and out of trouble.

As for local help, I wish to recognize my committee members, Bill Rose, Bill Gregg and Susan Bagley who provided numerous helpful comments and ideas in our meetings, in addition to Bill Everham who provided very useful feedback on my figure captions for this thesis. Thanks also go to Abass S. A., for his help in providing tips on biologic sample collection and preservation.

Lastly, I would like to thank my family, friends and Fraggle for supporting me in a myriad of ways, not the least of being their ability to put up with me in kind and tolerant ways when I was sleep-deprived and a little crazy. 


\section{Table of Contents}

Abstract _table of Contents _ _
List of Figures
List of Files
List of abbreviations and acronyms
Introduction
Purpose
Regional Setting
Literature Review
Geologic Introduction
Methods

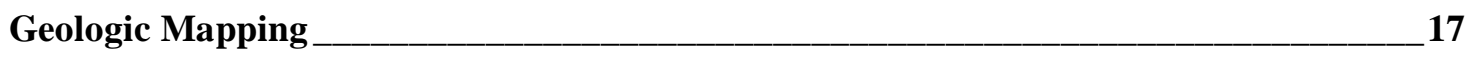

Part B: ______ 21

Time Series _____ 21

Volume and Petrographic Analysis ____ 22

Results and Discussion __ 24

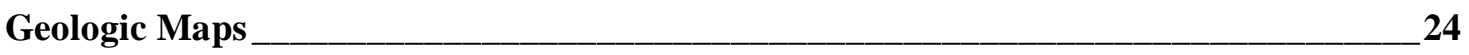

Rift Evolution and Time Series Images ___

Events prior to $10 \mathrm{Ma}$

10 to $6 \mathrm{Ma}$

$6 \mathrm{Ma}$ to $3 \mathrm{Ma}$

$3 \mathrm{Ma}$ to $2 \mathrm{Ma}$

$2 \mathrm{Ma}$ to $1.5 \mathrm{Ma}$

$1.5 \mathrm{Ma}$ to $100 \mathrm{ka}$

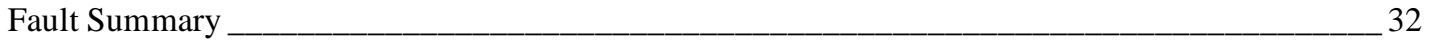

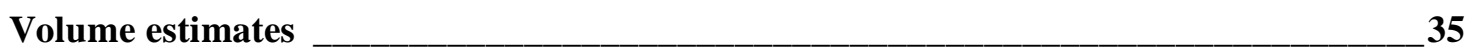

Magadi-area Sediments ___ 39

Part II: A Characterization of the Lake Magadi Area __ 46

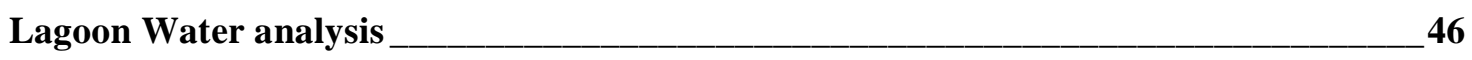

Volcanic gas estimates ________________________________

Lake Magadi Biology __________

Characterization of Lake Magadi Biology _______ 58

Conclusions___ 63

Evolution of the Southern Kenya Rift: 
Digital mapping_______ 65

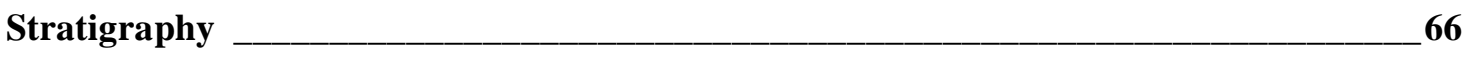

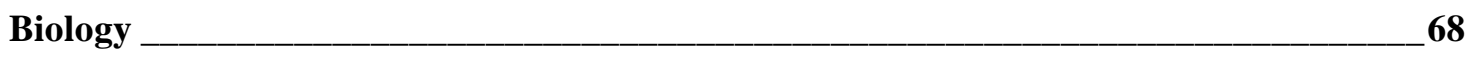

Future Work _ 68

Reference Library ___ 71

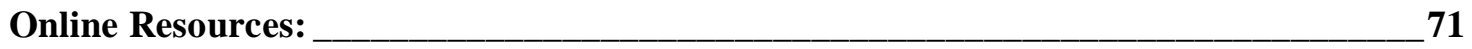

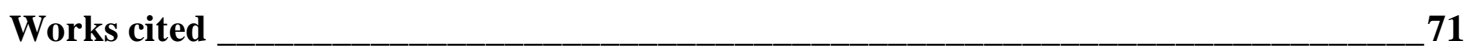

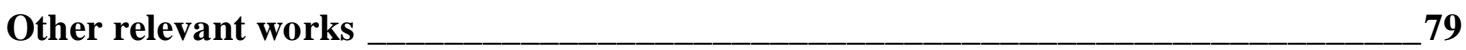

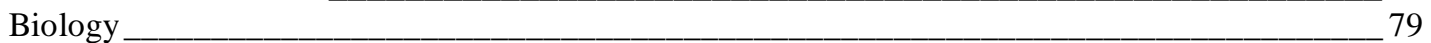

Climate Change and Geochronology ___ 80

Geochemistry

Plumes and Structure _______ 82

Sedimentation______ 83 


\section{List of Figures}

Figure 1: Shaded Digital Elevation Model (DEM) of Eastern Africa showing the rift system. To the north, the typical three-arm rift is apparent with two of the arms already having been flooded to form the Red Sea and the Gulf of Aden and with the third arm going to the south as the Main Ethiopian Rift. This branch splits around the Lake Victoria region to form the Eastern and Western branches, with the study area being a part of the Eastern Branch.

Figure 2: Assemblage of Kenya Geological Survey (1958-1991) maps on the right covering the study area. Note the changes in detail and color across map boundaries. Enlargements are shown to highlight such changes. A) shows the intersection of the northern four maps (clockwise from upper left: Suswa, Nairobi, Magadi and Kajiado maps) B) is the intersection of the southern four (clockwise from upper left: Magadi, Kajiado, South Magadi and Namanga maps).

Figure 3: A false-color Landsat image of the study area obtained from the NASA GeoCover web site showing roads (yellow), the Kenya-Tanzania border (white) and selected towns and features.

Figure 4: False color Landsat image draped over a DEM to emphasize the fault scarps and their relation to the lagoons (labeled after Baker 1958) surrounding Lake Magadi.

Figure 5: Map of the Southern Kenya Rift showing the major, named, rift bounding faults. Also shown are the outlines of Suswa, a shield volcano in the northern part of the study area, and Lakes Magadi and Natron. The grey line running diagonally through the image between the two lakes is the Kenya-Tanzania border. Nairobi is also shown for reference.

Figure 6: Plan view diagram showing location and source of geologic maps used as keys to interpreting the satellite images. Note that the larger (roughly quarter degree) maps were done by the Kenya Geologic Survey and the smaller maps which overlap them were from papers published later and provide much of the new detail seen in the maps produced for this study. Also note that while the publication year for Randel and Johnson and Saggerson is 1991, the mapping was done in the 1960's, therefore the overlapping maps from 1976 and 1981 reflect more recent geologic information.

Figure 7: Geologic map of Magadi Area (Baker 1958) overlaid onto a Landsat image. The geologic map has been georeferenced using the stated corner coordinates. This unedited mosaic shows a distinct offset between the coordinates of the geologic map and the Landsat image.

Figure 8: Mosaic of central portion of Lake Magadi using geologic map (Baker 1958), which has been simplified to a line drawing, and Landsat image (bands 1,2,3). Coordinate offset between the geologic map (black lines) and the Landsat image is 
clearly evident. Offsets range from 590-800 $\mathrm{m}$ and displacement azimuths vary between $70-122^{\circ}$.

Figure 9: Geologic map (from Baker 1958, left) and Principal Components (PC) image (right) of the Lake Magadi area. The PC image was created from a 2005 ASTER satellite image using the thermal bands. The Chert Series (Green Beds) are shown in red on the geologic map and matching areas can be seen as dark magenta in the PC image.

Figure 10: Diagram illustrating the evolution of the northwest section of the Magadi map area, based on events outlined in Crossley, 1979. Images from top to bottom, left to right, show the progression from $16 \mathrm{Ma}$ to $1 \mathrm{Ma}$. The final image shows a complex relationship between a variety of volcanic formations, but this can be arrived at through a series of relatively simple steps. For example, a fault cuts basement rocks and lava is erupted into the graben and overtops the escarpment (b). Renewed faulting breaks up the volcanic flow (c) with the down dropped part buried by more recent volcanism (d). These simple processes lead to the situation where one unit is seen at various elevations and is only covered by younger flows in certain locations.

Figure 11: Completed geologic map of the Southern Kenya Rift. This map extends from $1.5^{\circ} \mathrm{S}$ to the Tanzania border with the exception of a small area (southwest corner of map) that extends into Tanzania. Map covers the following KGS map areas: Suswa, Nairobi, Magadi, Kajiado, South Magadi and Namanga.

Figure 12: Comparison between Baker's 1958 Geological map (left) and Landsat image (right). The Oloronga lake beds are shown in yellow near the bottom of the geologic map (see arrow). In the Landsat image the Oloronga beds are easily distinguished from the Quaternary sediments by their light purple color (see arrow). For the geologic map produced in this study, the boundaries seen in the Landsat image were given preference over the 1958 map, which is confirmed by mapping done by Crossley (1979), and reports by Potts et al. (1988) and Shipman et al. (1983) that place the Lainyamok hominid site (represented by the star) within the Oloronga Beds.

Figure 13: Comparison of exposed trona in the southern end of Little Magadi. Image on the right is a December 2005 ASTER image with the yellow box showing the area of interest as seen during different years on the left. A: Baker's 1958 Geologic Map B: December 2005, a known dry year. Note the large exposure of trona (bright white), which is probably exposed due to lower water levels. C, D: 2003 was a more normal year in terms of precipitation and the exposed trona is significantly less than in B. This clearly shows that the amount of trona exposed is the result of a dynamic system and will vary year to year.

Figure 14: Lake Magadi through the seasons, with the upper left image from 2005. The light blue/white color is trona while black areas are water. During the rainy season 1$3 \mathrm{~m}$ of water submerges the trona surface which is then exposed again as the water evaporates. 
Figure 15: Landsat image of the northern Olorgesailie area showing three different road traces that are meant to represent the same road. The red line is from Digital Chart of the World (DCW), the green line is GPS data collected during the 2006 field season, and the yellow line represents the road as seen on the Landsat data. The offsets were measured at four locations within the zoomed area, perpendicularly to the three traces, and the averages are as follows:

$\begin{array}{ll}\text { DCW-Landsat: } & 287 \mathrm{~m} \\ \text { DCW-GPS: } & 235 \mathrm{~m} \\ \text { GPS-Landsat: } & 54 \mathrm{~m}\end{array}$

Figure 16: 10 Ma Paleomap. The first volcanism in this area was likely the Kishalduga and Lisudwa melanephelinites (light blue) which were erupted as early as $15.2 \mathrm{Ma}$ near what would become the western rift boundary. By $10 \mathrm{Ma}$ the area of the Southern Kenya rift was flooded by Plateau Phonolites (green), of which only the southern-most limit enters the study area. Graphs on the right show composition of volcanics (upper right) and volume (lower right). Composition plot shows total alkali versus silica with units erupted by $10 \mathrm{Ma}$ shown in color. The volume plot shows volume based on measured area (taken from the geologic map shown in Figure 10), volume based on estimated area (area of total estimated extent, or area shown in paleomap) and cumulative volume. The cumulative volume excludes the Plateau Phonolites shown on this paleomap as the 3 different shades of green.

Figure 17: 6 Ma paleomap. The initial fault movements to define the western rift boundary occurred before $7 \mathrm{Ma}$. These movements downthrew much of the Kishalduga formation and the Lengitoto trachytes were erupted into the newly formed half graben. Some rocks from the Ol Esayeti complex to the east have also been dated to this time period suggesting that it may have begun building during this time.

Figure 18: 3 Ma paleomap. More than 3 million years after the initial movements that defined the western rift boundary, corresponding movements occur to the east. There are additional fault movements along the western boundary during this time as well. Phonolites and Phonolitic-nephelinites seen on the east rift should are thought to be related to Olorgesailie, so the volcano was likely building at this time. The Ngong hills are also thought to have developed in this period. The Kirikiti basalts erupted against the western boundary faults and extend to the present location of Sambu in the South. The Nairobi trachytes in the north were probably erupted within the rift and overflowed onto the rift shoulders.

Figure 19: 2 Ma paleomap. A number of volcanoes developed between 3 and $2 \mathrm{Ma}$ including Sambu, Shombole, Lenderut, and Gelai in addition to further eruptions from Olorgesailie. Some small trachyte eruptions occurred on the eastern shoulder as well as the eruption of the Kerichwa Tuffs. Within the rift the Singaraini basalts were erupted along the eastern side and the Kordjya basalts were erupted in the area northwest of present-day Lake Magadi. The Mosiro and Ewaso Ngiro trachytes were also erupted onto the rift floor at this time. 
Figure 20: 1.5 Ma paleomap. Between the eruption of the Mosiro trachytes around 2.3 Ma and the Limuru trachytes at $1.9 \mathrm{Ma}$, much of the northern study area was likely covered by trachyte flows. The Limuru trachytes also overflowed the eastern fault scarps and flowed onto the rift shoulders. There were some smaller, more localized eruptions of Pantellerites and Benmoreites during this period. The oldest lake beds in the study area are in the Lake Natron basin and are about 1.5 Ma indicating the presence of a paleolake at this time.

Figure 21: 100 ka paleomap. The center of the rift floor was flooded by the Magadi (a.k.a. Plateau) trachytes which were probably erupted from fissures. The oldest flows in this eruptive series are $1.4 \mathrm{Ma}$ with activity continuing until around 780ka. A number of small cones (both trachytic and basaltic) were formed around 600ka and the Mau ashes in the northwest were erupted around the same time. The rift floor was broken by a number of small faults that have been dated to around 400ka. Suswa, a shield volcano in the north of the study area, began erupting around $240 \mathrm{ka}$. There was likely a large lake occupying the Magadi and Natron basins at this time, and a massive flood caused by the catastrophic draining of a lake in the Suswa area is thought to have occurred at this time.

Figure 22: Graph showing estimated fault displacement over time. Blue bars represent vertical displacements in meters along the faults that define the western boundary of the rift. Red bars are the same except for eastern boundary faults and green bars represent fault displacements in the rift floor. See Table 1 in text for references for displacement estimates.

Figure 23: Volume versus time plot for the Southern Kenya Rift volcanics. The blue bars represent the volume calculated from exposed (mapped) surface area. The red bars show volume based on estimated probable extent and the Orange line represents the cumulative volume based on estimated volumes without input from the Plateau Phonolites.

Figure 24: This plot is the estimated volume versus time as in Figure 23, except that the bars have been subdivided to show the contribution of the different types of volcanic rocks. It is clearly shown that volume of the different major volcanic rock types has not been constant over time.

Figure 25: Graph of fault displacement and erupted volcanic volume versus time. Yellow diamonds represent erupted volume in cubic kilometers and bars represent fault displacement in meters. Bars indicate fault displacement in meters on the western boundary faults (blue), eastern boundary faults (red), and in the rift floor (green).

Figure 26: ASTER image of Lake Magadi (December 2005) on the right with the area of focus enclosed by the yellow box. Images on the left show the active mining area in 2000 (A) which was relocated sometime between 2000 and 2003.

Figures 27-33: Images showing hotspring biologic samples A1-A7 in the field and under the microscope along with their proposed identifications. 


\section{List of Tables}

Table 1: Major fault movements in the southern Kenya Rift

Table 2: estimated volumes in $\mathrm{km}^{3}$, for various units and total volcanics from different authors including data from this study. Note that the Totals may not equal the sum of the boxes above, as a number of basalt and trachyte flows were not directly comparable to calculations done by previous authors, but are tallied into the totals to represent activity in the study area.

Table 3: Sedimentary and Volcanic formations of the Lake Magadi basin and their ages

Table 4: Comparison of $\left[\mathrm{Na}^{+}\right]$and $\left[\mathrm{Cl}^{-}\right]$in Spring Waters at Lake Magadi Kenya. Values are expressed in mmol/L. Stevens (1932) did not provide totals for the sodium and chlorine ions, so values presented here are summations from measured species containing these ions.

Table 5: Pixel calibration measurements for digital microscope images taken with a MTI 3CCD camera on a Zeiss Axioplan2 microscope.

Table 6: Basic water conditions for the different cyanobacteria samples in addition to infield sample description and proposed identification. Refer to Figures 27-33 for images of each of the samples and their proposed identifications. 


\section{List of Files}

\begin{tabular}{|c|c|c|c|}
\hline File Name & File Type & File Size & Description \\
\hline Ages & XLS & $160 \mathrm{~KB}$ & Compilation of Age Dates \\
\hline Comp & XLS & $72 \mathrm{~KB}$ & Chemical Compositions \\
\hline KenyaMap & PDF & $178 \mathrm{MB}$ & Map of Southern Rift \\
\hline KenyaShp & ZIP & $3.7 \mathrm{MB}$ & All .shp and associated files \\
\hline Magadi & PDF & $47 \mathrm{MB}$ & Magadi Field Guide \\
\hline
\end{tabular}

Note: Clicking on the above links will open the files described 


\section{List of abbreviations and acronyms}

ASTER: Advanced Spaceborne Thermal Emission and Reflection Radiometer

DEM: Digital elevation model

DCW: Digital chart of the world

DO: dissolved oxygen

EARS: East African Rift System

ETM+: Enhanced Thematic Mapper Plus, sensor on Landsat 7 that detects visible, infrared and thermal data, in addition to a higher resolution panchromatic band that can be used to sharpen the other images collected by the sensor

GPS: Global Positioning System

ka: kilo-annum, one thousand years

KGS: Kenya Geological Survey

KRISP: Kenya Rift International Seismic Project

Ma: Mega-annum, one million years

Moho: Mohorovicic Discontinuity, the boundary between the crust and mantle

MrSid: Multiresolution Seamless Image Database, a file type commonly used for very large image files used in GIS. Files from NASA's GeoCover page are of this type.

m.y.a.: million years ago

NASA: National Aeronautics and Space Administration

NIR: near infra-red

SEM: Scanning electron microscope

SRTM: Shuttle Radar Topography Mission 
A. Guth, MS Thesis, 2007

\section{Introduction}

\section{Purpose}

The East African Rift System (EARS, Figure 1, Appendix A) has been the subject of a number scientific studies in a variety of fields; geology, paleontology, biology and anthropology, among others. Human history is intimately linked with the rift, and recent papers (Potts et al., 2004; McBrearthy and Jablonski, 2005; White et al., 2006; Wynn et al., 2006; etc...) have been published regarding new finds from the human family tree in the rift system. These different studies all rely in one way or another on the unique geological setting of the rift valley. However, except for some small-scale detailed maps for scattered locations, most of the geological maps for the Kenya Rift are vintage 19501960’s Kenya Geological Survey (KGS) reconnaissance maps. The term 'vintage' is used here and throughout this thesis to refer to the fact that these maps were produced several decades ago, and, though they are of high quality, they are, in many instances, outdated based on newer data and mapping efforts.

Modern satellite imagery now provides large volumes of versatile and geographically accurate data world-wide that can be adapted for a variety of uses including geologic mapping. It is an indispensable tool for mapping remote and/or hostile (environmentally and/or politically) areas that would require many man-hours at great expense to map in the field. In addition, satellites like Landsat 7 and ASTER (Advanced Spaceborne Thermal Emission and Reflection Radiometer) collect data from the infrared and thermal bands, in addition to the visible wavelengths, which can aide in the mapping of geologic units. The older, mostly grayscale, aerial photography that many of the early 
A. Guth, MS Thesis, 2007

maps were based on lacked this added dimension. Accurate, detailed, cohesive and adaptable geologic maps are essential to many studies but are not, generally, available for many parts of the EARS.

The primary aims of this study are to:

- Remap the geology of the southern Kenya Rift in a digital format using satellite images and modern software

- Compile published age dates and combine with the digital map to create a time series of images that show the evolution of the rift

- Extract volumetric data from the digital mapping effort and combine with the age dates to analyze volume versus time

Many of the previous geologic maps were mainly reconnaissance in nature, some are based on incorrect base maps and do not align correctly with georeferenced satellite images or adjacent maps, and unit detail and naming can change abruptly at map boundaries (Fig. 2). The newly produced maps are seamless over several square degrees and can be applied to a variety of scientific problems relating to the EARS, such as the origin of the salt deposits at Lake Magadi and the volcanic evolution of the area. Also, the digital format will facilitate the distribution of these maps and digital files would be easily adaptable to suit various needs.

A description of the study area is provided below and is followed by a review of the literature regarding the Southern Kenya Rift and Magadi areas, with a focus on those studies that dealt with the evolution and mapping of this area. The methods used for mapping, constructing rift evolution time series images and determining volume estimates follow the literature review. Results and discussion of the mapping, evolution 
A. Guth, MS Thesis, 2007

and volume estimations are then presented and are followed by Part II, which contains ancillary information as described in the two paragraphs below. The main conclusions and recommendations for future work may be found following the ancillary data. In addition to the standard list of references, a library of pertinent works will also be included as there are many papers devoted to the Kenya Rift and EARS, and while all were read during the course of this study, not all were cited. Accumulating all of these papers took considerable time, and some were found by chance or referenced only rarely by others. This library is provided for completeness and to acknowledge the many researchers who have studied this area before.

While the main focus of this thesis will be mapping the evolution of the Southern Kenya Rift, other unique problems of the Magadi area will be briefly discussed such as water analyses, volcanic gas estimates in relation to the source of carbonate in the spring waters and the biology of Lake Magadi. This will be done to characterize the present lake system in an effort to define the current state of rift evolution in this area. The present environment is a product of the geological evolution of the Southern Kenya Rift, and is interesting in its own right. Discussion and results regarding these studies can be found in Part II of this thesis.

Additionally, an electronic field guide was developed from the 2005 and 2006 field excursions to Lake Magadi in order to present images, descriptions and geographic coordinates for points of interest (both general and geologic) in a readily accessible form. The reasoning behind this effort was that such a guide could help new investigators better visually interpret their surroundings and hopefully expedite research and interest in this area. This field guide is included in Appendix I on the CD included with this thesis. 
A. Guth, MS Thesis, 2007

\section{Regional Setting}

Lake Magadi is a sodium-carbonate alkaline lake (with minor $\mathrm{NaCl}$ and $\mathrm{NaF}$ ) occupying 89 sq. km in a closed basin within the East African Rift near the KenyaTanzania border (Fig. 3). Of that lake area, 77.7 square kilometers is trona $\left(\mathrm{Na}_{3}\left(\mathrm{CO}_{3}\right)\left(\mathrm{HCO}_{3}\right) \cdot 2\left(\mathrm{H}_{2} \mathrm{O}\right)\right.$ most of the year rather than open water, which is generally constrained to the shallow lagoons fed by hot springs located at the base of fault scarps. This trona deposit is the reason why there is a town here. The Magadi Soda Company is located on a small peninsula on the eastern shore of the lake, and produces soda ash by washing and calcining trona. The soda has many manufacturing uses and is a major part of Kenya's mineral exports with over 337,000 metric tons of Magadi soda ash being exported in 2004 (Yager, 2004).

A digital elevation model (DEM) created from the version 2 Shuttle Radar Topography Mission (SRTM) data shows Lake Magadi sitting at an elevation of $605 \mathrm{~m}$, and Little Magadi to the north at $613 \mathrm{~m}$ (published elevations for Magadi range from 580m (Behr-Röhricht, 2000) to 650m (Eugster 1969)). Magadi is flooded seasonally by rainwater, and a thin layer (1-3 m) of water covers the trona surface during part of the year. This water evaporates during the dry season and exposes the trona surface, with the only open water being found around the springs and in the lagoons (Fig. 4). These springs vary in temperature, from around $40^{\circ} \mathrm{C}$ to above $80^{\circ} \mathrm{C}$, mineral concentration, size, and output, with some springs being only seeps and others being relatively vigorous. Lake Magadi is supplied with water from these springs and by monsoonal rains (there are two rainy seasons, the 'long rains' from March to May, and the 'short rains' from November to December); no perennial rivers or streams flow into this basin. It is about $110 \mathrm{~km}$ from 
A. Guth, MS Thesis, 2007

Nairobi, and once there, the road network is mostly a series of 4-wheel drive tracks. The terrain is broken by numerous faults, easily seen in Figure 4, and the scarps and poor roads combined with the hot climate makes for difficult field work.

Sediments are confined to the grabens produced by the faulting of the volcanic units that comprise most of the rift fill. Around Magadi the flat graben floors are the deposits of old lakes and the horsts are trachytes that range in age from 1.4 to 0.7 Ma. The largest displacements occurred along the bounding faults of the rift (Fig. 5) which create a significant elevation difference between the rift shoulders and floor. Nairobi, which sits on the rift shoulder, has an elevation about 1060m higher than Magadi which is in the rift.

\section{Literature Review}

With geological interest in the area dating back to the late 1800's, there are numerous papers and reports regarding the Lake Magadi area. A review of some of the earliest investigations of the Lake Magadi region is covered by Baker (1958), with some of the early work described briefly here per Baker's report. The first extensive report on the geology was published by Parkinson in 1913 and described the faults, lake sediments and the silicification in lake beds and along fault lines. He also proposed that the salts in the hot springs were derived from the leaching of alkaline lavas. J.A. Stevens wrote a report for the Magadi Soda company in 1932 (unpublished, but much of the data are reported in Baker 1958) regarding the chemical composition of the hot spring waters surrounding Magadi.

Copyright $\mathbb{C}$ Alexandria L. Guth 
A. Guth, MS Thesis, 2007

Baker's "Geology of the Magadi Area", published for the KGS (1958), details the geology between $1.5-2^{\circ} \mathrm{S}$ and $36-36.5^{\circ} \mathrm{E}$, and includes information on the geologic units of the area and hot springs, along with chemical analyses of spring waters and some sketch maps. A large format map accompanied this report and is the only large scale map known to cover this entire quadrangle. However, the map is currently out of print from the KGS. By the time Baker published his report "Geology of the Area South of Magadi (1963), it was determined that the base map used for the Magadi area was in error and thus the map cannot be registered to correctly overlie the recent satellite data. In addition, the map is over 50 years old and the geology of the area has been further defined by other investigators over the years. Quantitative age dates for the geologic units are also lacking in this report, and it was not until the 1970's that age dates based on modern geochronological studies began to appear. After these two reports Baker continued to be a major publisher on the geology of this area until his death in 1986.

In addition to age dates, a number of papers from the 1970's added further definition to Baker's original map by recognizing new units or by renaming or regrouping older units, with key mapping resources shown in Figure 6. Williams (1967) renamed the bulk of the Ol Keju Nero basalts described by Matheson in the Kajiado KGS report (1966) as the Singaraini basalts. A number of age dates from volcanic units were compiled and published in 1971 (Baker et al.) along with discussions about both the plateau volcanics, and the deposits of central volcanoes. Fairhead et al. (1972) also presented a number of K-Ar age dates, however, the age dates presented for the Kirikiti and Singaraini flows cannot be reconciled with newer age dates, which in turn affects Fairhead et al.'s presented timing for the faults and overall geochronology. One age date 
A. Guth, MS Thesis, 2007

presented in their paper for an obsidian flow within the Oloronga lake beds has been instrumental in setting the upper age limit of this sedimentary unit and has not been contested by any of the more recent studies of the area. The Singaraini basalts were themselves subdivided in a 1976 paper by Baker and Mitchell into the Singaraini, Ol Tepesi and the Ol Keju Nero basalts based on differing ages in the northern and southern exposures. Baker and Mitchell (1976) was also a key paper in that they mapped the Kordjya basalts as a distinct unit (previously mapped as Plateau Trachytes by Baker, 1958) and divided the Orthophyre Trachyte (Baker 1958) into the Ol Tepesi basalts and benmoreites. This same paper however, only mentions examining the eastern occurrences, but the western exposure of Orthophyre Trachyte is also mapped according to the new unit name. This is despite being outside of the area being considered in detail for the paper and not being represented in their sampling and age dating. This paper by Baker and Mitchell (1976) is mainly focused on the geology and ages of units centered in the Olorgesailie-Kedong region to the northeast of Magadi, and contains a nicely detailed map from approximately $1^{\circ} 7^{\prime} 30^{\prime \prime}-1^{\circ} 37^{\prime} 30^{\prime \prime} \mathrm{S}$ and semi-centered on the $36.5^{\circ} \mathrm{E}$ longitudinal line (Fig 6). This detailed map covers the four-corner intersection of the old KGS report maps and is very useful for correlating across the boundaries of the older maps. Baker and Mitchell also introduce in this paper the idea of a massive flood caused by the sudden draining of a lake to the north. Termed the Kedong Flood, the authors list a variety of evidence to support the mass movement of sediment-laden water. Deposits relating to this flood can be seen to the northeast of Olorgesailie in the Ol Tepesi Basin. These deposits are mapped on the detailed map they present, and are prominent, easily recognizable features on the satellite imagery. 
A. Guth, MS Thesis, 2007

Crossley (1979) conducted mapping of the western boundary of the Southern Kenya Rift and also presented new age dates for the area. This paper revealed that the western exposure of 'orthophyre trachyte' from Baker's 1958 report, (later renamed by Baker and Mitchell (1976) as the Ol Tepesi Basalts) was really two different units; the Ewaso Ngiro Trachyte and N. Kordjya Trachyte. Crossley also extended the mapped area of the Oloronga lake bed deposits to the northwest, and mapped a new lake deposit; the Orkaramatian beds.

While mainly concerned with the paleomagnetics of the area, Patel and Raja (1979) also published several small geologic maps in their paper, and, while lacking details seen in Crossley's (1979) map and the new units presented by Baker and Mitchell (1976), their work is of particular interest as their map shows several small outcrops of Kordjya basalts along the Kordjya escarpment and to the northwest of Little Magadi.

The region to the north (Kedong-Naivasha-Kinangop region) was covered in a 1988 paper by Baker et al. This, Baker's last paper, has some small maps covering the central and southern Kenya Rift which show major and minor fault patterns, and the simplified geology northeast of Magadi, in addition to a number of age dates.

Although there has been a number of mapping efforts for the South Kenya Rift since Baker's original KGS map (1958), these smaller maps have not been previously synthesized into a whole, comprehensive map.

Finally, with regards to geologic mapping, in researching the biology of the lake, one map cropped up in several papers (Wilson et al. 2000; Wilson et al. 2004) that was adapted from Maina et al. (1996). This map shows Lake Magadi and the main roads, and while it is not concerned with the geology of the area, it has an inaccurate lake outline, 
A. Guth, MS Thesis, 2007

uses different names for the lagoons surrounding the lake than found in the geological papers, and maps trona as being where there are only lake silts and chert. By having different names for the lagoons, comparing water analyses between these papers and those written by geological researchers can be confusing, and this author believes that this underscores the need for an easily accessible, accurate, map which can be flexible enough for suiting the needs of different scientific fields.

In addition to works focused on general geologic mapping and geochronology, certain units have received more attention than others. In particular, the cherts that are common in the Magadi area have been studied by a variety of authors, and their origin has been under debate for nearly 50 years. They were originally named the 'Chert Series' by Baker (1958) and placed between the Oloronga and High Magadi Beds in age. It was then determined that they were older than the Oloronga beds based on exposures to the south of Magadi (Baker, 1963). Hans Eugster became the foremost researcher on the Magadi cherts and wrote a number of papers over several decades regarding their formation. One of his earliest papers discusses the link between $\mathrm{pH}$ and chert deposition in the paper, "Silica in Alkaline Brines" (Jones et al., 1967). Silica enrichment in the waters of Magadi is believed to be due to evaporative enrichment and, due to the high $\mathrm{pH}$ of the brines, the silica can remain in solution. Eugster (1967) proposed that magadiite $\left(\mathrm{NaSi}_{7} \mathrm{O}_{13}(\mathrm{OH})_{3} \cdot 4(\mathrm{H} 2 \mathrm{O})\right)$, a soft, white layer that Baker (1958) had noticed in the High Magadi Bed exposures, was a chemical precipitate from the alkaline brines, and that kenyaite $\left(\mathrm{Na}_{2} \mathrm{Si}_{22} \mathrm{O}_{41}(\mathrm{OH})_{8} \cdot 6(\mathrm{H} 2 \mathrm{O})\right)$, was formed by the leaching of sodium from the magadiite by percolating water. It was believed that with further leaching of sodium, chert could be formed. In a 1968 paper Eugster and Jones discuss gels found near the hot 
A. Guth, MS Thesis, 2007

springs that feed the northeastern lagoon. These gels seemed to have been derived from the in situ decomposition of the trachyte lava debris, and the gels were probably reformed annually leading to a probably significant accumulation of silica gels in the lake. Eugster claimed that that the Chert Series originated from areas similar to those where the gels are found in the present, unlike the magadiite which was thought to be a lake-wide deposit. The Chert Series was noted to be aligned along faults, showed evidence of soft sediment deformation and seemed to show evidence of algal mat growth, all of which seemed to point to a soft, gelatinous, precursor. It was speculated that sodium leaching of the gels would convert them to the normal porcellaneaous chert seen in the field.

In 1969, Eugster tried to show that the Chert Series was stratigraphically equivalent to the magadiite beds in the High Magadi sediments based on digging trenches near the chert ridges and seeing that they seemed to be laterally contiguous with magadiite. He believed that the cherts were formed inorganically by the leaching of sodium from magadiite as discussed above. Having a putty-like precursor made it easy to explain the numerous soft-sediment type deformation seen in the chert, and in this paper he proposes that magadiite is the soft chert predecessor rather than the gels he discussed in 1968. Using aerial photography Eugster (1969) stated that the prominent chert ridges of the area formed closed polygons which were explained as being desiccation polygons. He proposed that the magadiite formed in a stratified lake where brines and freshwater came into contact and formed a chemocline where the $\mathrm{pH}$ would be lower but there would be an ample supply of silica. Magadiite could then precipitate at this boundary layer. After this paper, Eugster no longer refers to the Chert Series and instead places those rocks within the High Magadi Beds. 
A. Guth, MS Thesis, 2007

Schubel and Simonson (1990) continued the line of reasoning started by Eugster that the bulk of the cherts were formed inorganically from magadiite and conducted a more in-depth study on the cherts around Magadi. Behr and Röhricht (2000) however, believed that inorganic cherts formed from magadiite were actually rare in this area, and that they comprised less than $10 \%$ of the Magadi area cherts. They concluded that most of the cherts are older than the High Magadi Beds, and thus were older than the magadiite layers, and were formed from bioherms growing on silica gels (similar to those mentioned by Eugster and Jones in 1968) and thus contained numerous biologic remains. Seismotectonic activity then caused the collapse, liquefaction and extrusion of the plastic siliceous material resulting in the soft sediment type deformation. Instead of inorganic, putty-like magadiite, a mush of silica, calcite, and cyanobacterial remains was formed which remained deformable for long periods. Tectonic activity led to cracks in overlying bedded cherts, and the cyanobacterial mash could then rise to form diapirs and dikes. This is similar to Eugster and Jones’ 1968 theory regarding the gels seen at the northeastern lagoon and how they, rather than the magadiite, were the precursors for the Chert Series. Age dating indicates two generations of chert with about $90 \%$ of the chert in the Magadi Area being part of what Behr and Röhricht refer to as the Green Beds. This formation was placed between the Oloronga and High Magadi beds in age, which is where Baker had originally placed his Chert Series. It is the cherts in the High Magadi Beds, which overlie the Green Beds, that contain the magadiite and kenyaite horizons. Behr and Röhricht also present in this paper images of some of the biologic remains found in the chert and two very detailed maps showing the aerial distribution of the Green Bed chert exposures. However, it was noticed that one of the scale bars used for 
A. Guth, MS Thesis, 2007

these detailed maps is inaccurate and is inconsistent with the scale provided on the location map in the same image. The inaccurate scale bar makes the mapped area appear about three times larger than it really is.

Behr (2002) continued the study of cherts in the Magadi area and found that the chert ridges follow a $90^{\circ}$ grid pattern, which can be correlated with faults, and no desiccation features as postulated by Eugster were found. Behr presents a nice stratigraphic record of the sedimentary units of the Magadi Basin and shows the names used by Baker and Eugster, fossil distribution, and lake level development. He also goes into more detail about the biologic remains found in the cherts and includes a number of thin section and Scanning Electron Microscope (SEM) images of the remains found. 
A. Guth, MS Thesis, 2007

\section{Geologic Introduction}

It is generally believed that the incursion or one of more plumes occurred before the initiation of rifting (Burke and Wilson, 1976; Thiessen et al., 1978; Latin et al., 1993; Hofmann et al., 1997; Davies, 1998; Ebinger and Sleep, 1998; George et al., 1998; Nyblade and Langston, 2002; Nyblade, 2003; Weeraratne et al, 2003; Nyblade et al., 2004; Rogers, 2004). The exact number, timing, and migration of plumes is under debate. The oldest volcanism occurred in the Turkana region around 35-30 Ma (George et al., 1998; Macdonald, 2003; McDougall and Watkins, 2006) and initiation of magmatism has been noted by a number of authors to decrease in age to the south (Khan et al., 1999; Nyblade and Brazier 2002; Macdonald et al., 2003; Chorowicz, 2005 etc.). The East African Rift System as a whole, propagated to the south at a rate of $2.5-5 \mathrm{~cm} / \mathrm{yr}$ and avoided cratons. Instead, the rift system propagated along the old mobile belts from the Neoproterozoic Pan-African events (Chorowicz, 2005).

Downwarping in the Kenya Dome occurred where the rift would eventually develop and large amounts of volcanics (basalts, phonolites and melanephelinites) were erupted into this proto-rift during the Miocene (Crossley, 1979; Williams and Truckle, 1980; Smith, 1994; Macdonald, 2003). From the Miocene to present, volcanic flows and ashes dominate the Southern Kenya Rift in terms of both duration of activity and volume of deposits. Sedimentary units are generally limited in area and confined to grabens within the rift valley. While deeper sedimentary basins exist to the north of the study area and in the western rift branch, in the Southern Kenya Rift such basins are recent and lack significant sedimentary fill. 
A. Guth, MS Thesis, 2007

An obvious feature of the rift is the large number of fault scarps that cut the landscape and form sediment-trapping grabens. Very few of the faults are actually exposed, but two normal faults were measured by Baker $(1958,1963)$ and found to have dips around $60^{\circ}$. The tilted fault blocks that are common in this area are suggested to indicate the presence of curved faults that get shallower with depth; combining this with the observed vertical displacements (which is a minimum estimate of total displacement) on the faults, a minimum horizontal extension was estimated at $15 \mathrm{~km}$ by Baker et al. (1977a) and revised to $20 \mathrm{~km}$ by Baker et al. (1988). These estimates were made assuming that all the faults dip at $60^{\circ}$ and gives an estimated extension rate of $3 \mathrm{~mm}$ per year, however, it is noted by these authors that extension rates were probably variable over time due to periods of discrete faulting.

In regards to the calculations presented by Baker et al. (1977a, 1988), it was noted by Crossley (1980) that fractures in the rift floor were nearly vertical and dips on the Sambu fault vary from $65^{\circ}$ to $45^{\circ}$, making the assumption that all faults dip at $60^{\circ}$ overly simplistic. Additionally, the assumption that the boundary faults become listric with depth seems to be contradicted by the results of Ibs-von Seht et al. (2001), where plotted earthquake foci seem to indicate that the western boundary faults of the Magadi area dip at $65^{\circ}$ to at least $25 \mathrm{~km}$ depth.

Recent stretching factor ( $\beta$-factor) estimates for the southern Kenya Rift, which are based on the thickness ratio of crystalline crust outside the rift to the thickness inside the rift, yield values always less than 1.4 for this area (Khan et al., 1999). Despite the various difficulties in pinpointing the exact amount of extension for the area, it is 
A. Guth, MS Thesis, 2007

generally reported (Khan et al., 1999; Macdonald, 2003; Prodehl et al. 1997, etc...) that the extension is between 5 and $10 \mathrm{~km}$ for the Southern Kenya Rift (which would be equivalent to a $\beta$-factor of 1.1 to 1.2 ). A full $10 \mathrm{~km}$ of extension over 7 million years would lead to an average of $1.4 \mathrm{~mm} / \mathrm{yr}$ extension. For comparison, present extension in the Main Ethiopian Rift (MER) has been measured to be $4 \mathrm{~mm} / \mathrm{yr}$ based on GPS measurements (reported in Keranen et al., 2004), however, it is unknown if similar GPS measurements have been made for the Kenyan Rift.

Also, the studies by Keranen et al. (2004) have shown that extension in MER can be attributed to a combination of fault movements and injection of magma into the crust, which has also been discussed by authors for the Kenya Rift. In fact, it was recently reported that $60 \mathrm{~km}$ of fracturing in the Afar region was caused by the lateral flow of magma from chambers below local volcanoes into dikes $2-9 \mathrm{~km}$ below the surface (Sigmundsson, 2006). This created fissures up to $8 \mathrm{~m}$ wide in the rift floor and it is postulated that this method of extension can happen well before lithospheric thinning progresses to the point of allowing normal faulting. For the section of the MER studied by Keranen et al., (2004) a maximum of $6 \mathrm{~km}$ extension could be accounted for by dike injection while fault displacements accommodate more than twice that.

Recent seismic surveys have been conducted for sections of the EARS and have allowed for the visualization of the rift structure. Of these studies, the KRISP (Kenya Rift International Seismic Project) surveys have provided large volumes of data, and. Importantly for this study, had shot points at Magadi (Green et al., 1991; Ibs-von Seht et al., 2001; Khan et al., 1999; Prodehl et al., 1997; Simiyu and Keller 1998, 2001). These studies show that the severe crustal thinning that had been earlier assumed to exist under 
A. Guth, MS Thesis, 2007

Magadi was not present, and in fact crustal thinning at Magadi is less than the thinning seen at Lake Baringo. Only a minor upwarping of the mantle was seen (Prodehl et al., 1997), however, it was later argued however, that lack of observed thinning could be explained by underplating of the crust by magmatic materials related to rifting (Simiyu and Keller, 2001). 
A. Guth, MS Thesis, 2007

\section{Methods}

\section{Geologic Mapping}

Baker's 1958 Magadi map (but not the report that is meant to go along with it) is out of print and difficult to obtain. In the "Geology of the Area South of Magadi" report, Baker (1963) reported that the base map used for the Magadi Area had been in error. This can easily be seen when the map is georeferenced using the stated corner coordinates from the map and overlaid on a satellite image (Figures $7 \& 8)$. These errors would be difficult to correct, as the offset is not a simple shift in one direction, but rather a complex warping.

Landsat 7 satellite images (false color images using bands 7, 4 and 2) were used as the new base map (obtained as compressed MrSid files from NASA's GeoCover webpage) and geologic boundaries were traced from the satellite images using previously published maps (Baker 1958; Baker and Mitchell, 1976; Baker et al., 1988; Behr, 2002; Crossley, 1979; Crossley and Knight, 1981; Joubert, 1957; Matheson, 1958; Patel and Raja, 1979; Randel and Johnson, 1991; Saggerson, 1991; see Figure 6) as geologic keys. Where possible, nomenclature and shown geologic boundaries from the originally published maps were used, but there were occurrences where the satellite imagery and the published maps were in disagreement (such instances are noted in the Results section of this report). The smaller scale, more recent maps (not published by the KGS) included new units and added detail which were incorporated into the newly produced map presented with this thesis. For this study, six quadrangle maps covering the lower part of the Kenya Rift, from $1^{\circ}$ South to the Tanzania border, were remapped in detail in this 
A. Guth, MS Thesis, 2007

manner. It should be noted that using satellite images to aide in the mapping and analysis of the Southern Kenya Rift is not novel. Mboya (1986), Gaciri (1992) and Atmaoui and Hollnack (2003) all used satellite images to map lineaments and help analyze the structure of the region. Newer techniques using the synthetic-aperture radar method (satellites such as RADARSAT-1 and the European Space Agency's Envisat) allow for the calculation of cm-scale changes in elevation that is useful in tracking deformation caused by movement of magma and has been applied to areas north of the current study area (Poland, 2006; Sigmundsson, 2006).

As noted previously, the formation names and detail can change when crossing a map boundary. An effort was made to preserve the most detail when crossing a boundary. To facilitate this, a unit correlation table was constructed showing the units and their equivalents in each of the KGS maps (Appendix B). A similar chart was constructed by Baker (1965) but age dates and newer studies have helped improve the correlation efforts. Units that are considered correlative (based on either description, correlation made by previous papers, or by matching unit boundaries across maps) are placed in the same row and units that are similar but do not have exact equivalents are placed under the correlating units and are alone in the row. Some formations present in older maps have since been subdivided based on newer age dates or petrological studies. In such cases, the old name is in the table for completeness, with the newer name, which takes precedence, highlighted.

ASTER (Advanced Spaceborne Thermal Emission and Reflection Radiometer) imagery was also used to augment the mapping of some units around Magadi. ASTER images have the advantage of being obtainable as time series data and have increased 
A. Guth, MS Thesis, 2007

spatial resolution for the visual and near infrared (NIR) bands compared to the Landsat 7 data. ASTER visible and NIR bands are collected at $15 \mathrm{~m}$ spatial resolution, while the similar Landsat 7 bands are collected at $30 \mathrm{~m}$ and then sharpened to $15 \mathrm{~m}$ using the panchromatic band; however, this sharpening process cannot produce an image as clear as one simply taken at $15 \mathrm{~m}$ resolution. Also, ASTER images contain information from 14 spectral bands, and some of the thermal bands proved useful for mapping cherts of the Green Bed series. Areas known to be the Green Beds (Chert Series) could be seen to standout in the thermal bands $(8.125-11.65 \mu \mathrm{m})$ and this was enhanced by performing a Principal Components transformation on the thermal bands (Figure 9). It is unknown why these beds stand out in the thermal images, and time did not allow for an in-depth investigation of this phenomena.

The bulk of the digital mapping was done in Global Mapper by using the geologic maps and satellite imagery as discussed above. Each formation was traced on the satellite data and then saved individually as vector shapefiles (an ESRI file format that saves attribute tables and projection information along with each file). It was attempted to map each formation out in its entirety rather than stopping at artificial boundaries (political boundaries or certain lat/long coordinates), which is one reason mapping was continued across the Kenya-Tanzania border into the Lake Natron region. Once the shapefiles had been created for each geologic formation, the map was then assembled in ESRI's ArcMap due to its enhanced layout, legend and symbol tools.

In addition to act of mapping the geology, some changes had to be made when constructing a printable map. Many of the abbreviations used on the old KGS maps utilized numbers to indicate the order of formations during a certain time period. Since 
A. Guth, MS Thesis, 2007

six maps were combined for this study, and each KGS map had its own abbreviation system, it was decided to devise a new scheme that could be expanded as needed to accommodate new maps into the process. The general system produced abbreviations such as Pkp, where 'P' stood for Pliocene, ' $\mathrm{k}$ ' was from the formation name (in this case for Kapiti), and ' $p$ ' indicates the unit is a phonolite. Epoch time divisions are based on those published by the International Commission on Stratigraphy (ICS) and the lower time boundaries are as follows: Miocene, 5.33 Ma; Pliocene, 1.806 Ma; Pleistocene, 11.5 ka.

There are also standard colors suggested by the ICS and the United States Geological Survey for geologic map making, however these could not be used satisfactorily due to the limited age range of the exposed rocks in the study area. Due to this, a color scheme was developed such that color families were related to the petrology/origin of the formations rather than the age. Ashes and tuffs are colored based on petrology, when known, in accordance with the proposed scheme. However, in some cases the composition of the ash is not given, in which case the ash formations are grouped based on texture (in that they are ashes) and represented by browns on the presented map.

Constructing cross sections through areas where previous cross-sections are absent or outdated requires a good understanding of how the area evolved. In order to visualize the succession of events and construct a cross section through the map area, a series of block diagrams were constructed to diagrammatically represent the major events west of Lake Magadi. These can be seen in Figure 10 and were constructed mainly using the ages and events outlined in Crossley 1979 while attempting to understand how his 
A. Guth, MS Thesis, 2007

cross sections fit with his order of events. While Crossley presents a cross section of the area and describes the events that occurred to create the present situation, it was difficult to conceptualize without a visual aide. Figure 10 represents the events described by Crossley (1979) and demonstrates quite succinctly that a very complex situation can result from a series of simple steps. This exercise led further to the construction of similar maps for the entire study area to represent the geologic evolution from the Miocene to the present, as discussed below.

\section{Part B:}

Several products were derived from the initial mapping efforts, and are described here. They have been separated from the mapping methods to emphasize the fact that they were dependant upon the initial mapping and cross section processes as described above.

\section{Time Series}

To construct a visual time series of events, the first step was to compile age dates from the literature for as many formations as possible. This list of age dates can be seen in Appendix C. Since an age can be associated with almost every mapped formation, the shapefiles produced for digital mapping to represent the different formations can be grouped by age and then displayed to represent the activity during different stages of the rift evolution. 
A. Guth, MS Thesis, 2007

\section{Volume and Petrographic Analysis}

Having digital shapefiles also allows for quick determinations of the exposed surface area and, when combined with thicknesses estimates from the literature, can provide minimum volume estimates (areas and thickness used for volume calculations can be seen in Appendix D). Volumes obtained in this manner are considered to be minimum estimates because the exposed area does not account for the subsurface extent of the formations. Each formation probably had an area significantly larger than the mapped area, but after deposition the formations were eroded, faulted and/or partially buried by subsequent eruptions.

In some instances, a larger volume can be obtained to approximate original volume by estimating the total extent of the flow. This was already done, in part, for the volcanic units of the Nairobi region, by Saggerson (1991) who provided a map of probable maximum extents for some of the formations. For units that had patchy surface extents, larger volume estimates were obtained by assuming the original flow must at least had a perimeter that contained all visible outcrops. Some maximum extents were based on verbal descriptions in the literature, for example, Crossley (1979) mentions that the Kordjya basalts can be traced as far east as the western margin of the Magadi trough.

For the pre-rift units such as the Plateau Phonolites (which include the Kapiti, Kandizi, Nairobi, Mau, Kericho and Rumuruti (among other) flows, of which the Kapiti, Kandizi and Nairobi outcrop in the study area) it was assumed that they covered the entire area between their eastern and westernmost outcrops, which includes the area currently occupied by the rift. Smith (1994) also provides a map with the probable extent of the Plateau Phonolites which agrees with this assumption. Since they occurred before 
A. Guth, MS Thesis, 2007

the initial faulting and extension, the area currently occupied by the rift zone was contracted by $20 \%$, based on estimated $\beta$-factors (or stated extension in $\mathrm{km}$ ) mentioned by Khan et al., (1999) Macdonald, (2003) Prodehl et al. (1997) and others, for volume calculations.

In all cases a simplistic calculation was done assuming the flow was a sheet of even thickness and central volcano volumes were calculated as if they were cones. The calculated volumes, both those using mapped area and estimated extent, along with a cumulative volume, were then plotted versus time. These are also presented along the time series images with the time period corresponding with the image highlighted to facilitate discussion.

In addition to accumulation of age and volume information for various flows, chemical analyses were also gathered from a variety of sources (Baker, 1958; Baker, 1975; Baker et al., 1977b; Crossley and Knight, 1981; Gittins and Jago, 1998;

Macdonald, 2001; Le Roex et al. 2001; Otando, 2004; in addition to a number of analyses compiled by GEOROC) and plotted on silica versus total alkali plots. The full list of chemical analyses can be found in Appendix E. Individual plots for eruptions during discrete time periods are shown and discussed with their corresponding time series images in Results.

Copyright $($ ) Alexandria L. Guth 
A. Guth, MS Thesis, 2007

\section{Results and Discussion}

\section{Geologic Maps}

A small version of the map produced for this study is presented here as Figure 11. The full size electronic copy of the produced geologic map from $1^{\circ}$ South to the KenyaTanzania border, along with associated cross-sections, can be found in Appendix F. The associated shapefiles for all the geologic formations may be found on the accompanying CD in Appendix II.

As mapping was done from the Landsat images, and not simply by tracing the boundaries from the old maps, numerous small differences exist between the new digital map and the sources used to interpret the satellite data. Such minor changes will not be detailed here, but there were some significant changes and unit reassignments from Baker's 1958 map that were not made by previously published reports. These changes were made in the following areas:

- The northern border of the Oloronga Beds west of Magadi was mapped by Baker as being cut off at a near $90^{\circ}$ angle where Quaternary sediments were shown to cut across the lake beds. Such a boundary is not seen in the satellite images; however, there is a fairly distinct boundary on the western edge of the Oloronga beds which continues until it meets the Magadi Trachytes, which can be seen in Figure 12. The Oloronga beds are easily discernable from the Quaternary sediments in the satellite images. Using the same visual clues, the Oloronga beds also seem to occur in a basin to 
A. Guth, MS Thesis, 2007

the northwest of Magadi, which again is not shown by older geologic maps. This choice in mapping seems validated however, by the recent hominid research in Lainyamok, the basin northwest of Lake Magadi, where the sediments have been identified as belonging to the Oloronga beds (Shipman et al., 1983; Potts et al., 1988; Potts and Deino,1995).

- The area covering the lower third of Little Magadi was originally mapped by Baker as trona, whereas only small sections of the southern end show the distinctive trona response in the circa 2000 Landsat image. Comparing ASTER images from January, March and September 2003 and December 2005 showed that the extent of the trona in the southern corner of Little Magadi changes significantly between years and even a little between seasons (Fig. 13). The large amount of exposed trona in December 2005 in Little Magadi was most likely due to the drought that occurred during that year, while 2003 was considered to be a more normal year for precipitation (Earth Observatory, Kenya Red Cross). In addition to yearly variations, the amount of exposed trona in Lake Magadi is seasonal and it is assumed that during the rainy seasons the trona spectral response is masked by overlaying water (Fig. 14). For mapping, the minimum extent seen at Little Magadi was used, as this seems like the average extent during normal years, and the maximum extent of the exposed trona was used for Lake Magadi, as it more accurately reflects the area occupied by the trona deposit, distinctly defines the lagoon areas, and the lake basin exhibits this exposure every year during the dry season. It should be kept 
A. Guth, MS Thesis, 2007

in mind however, that the appearance of these two water bodies will vary during the seasons and between years.

A variety of vector data can be obtained online from Digital Chart of the World (DCW) including country borders, roads, rivers and population points. While these can be useful for identifying roads that might be otherwise hard to follow on sections of satellite images, there are a number disadvantages with these data: digitizing was done from maps at 1:1,000,000 scale so the resolution is not as fine as can be traced from the satellite data and features have a stated positional accuracy of $2 \mathrm{~km}$. This can be distinctly seen in Figure 15 which shows the DCW road file, a GPS track and the road as seen in the Landsat image. The GPS track is thought to be the most accurate, however, since only a small percentage of roads were driven and thus had a GPS track, and since geology was mapped using the Landsat imagery, it was determined that all roads would be mapped from the Landsat as well.

\section{Rift Evolution and Time Series Images}

\section{Events prior to $10 \mathrm{Ma}$}

Figure 16. In the highlands west of Lake Magadi there are several melanephelinitic units which exist as the old volcanic center Lisudwa, located between the Kirikiti and Sambu faults, and the Kishalduga Formation which is farther to the north above the Naitiami Fault. The Kishalduga rocks gave ages between 12-15.2 Ma, and all of these melanephalinitic rocks were erupted onto the metamorphic basement from fissures or volcanic centers within the downwarped area where the rift later developed 
A. Guth, MS Thesis, 2007

(Crossley 1979). These are the oldest known rift-related volcanics in the southern Kenya Rift.

One of the other early volcanic events is likely the Simbara basalts, which only outcrop in stream valleys north of Nairobi; this is assuming Smith (1994) was correct in his conclusion that these basalts are correlative with the Samburu basalts which have an age range of 14.2-23 Ma (Chapman and Brook, 1978; and Baker et al., 1971). This is despite a published age for the Simbara basalts in Baker et al. (1971) of 5.5 Ma, which Smith argues is really for a sample of the Sirrima Basalts, which are included within the Thomson's Falls Phonolites (that do not exist within this paper's study area). The Samburu basalts have an assumed fissure origin due to their sheet-like morphology and association with dike swarms and intrusive plugs (Smith, 1994).

The largest volcanic series to erupt in association with the doming and eventual rifting also occurred during this time and are termed the Plateau, or Flood, Phonolites. These eruptions give ages between 10-16.4 Ma (Logatchev et al., 1972; Chapman and Brook, 1978; Smith, 1994; Behrensmeyer, 2002) with the majority being erupted between 13 and 11 Ma (MacDonald, 2003). These phonolites represent the largest eruptive event within the central and southern Kenya Rift area (note that these were all erupted before the rift initiated) and represent over $40,000 \mathrm{~km}^{3}$ of extruded material. Within the study area however, which only represents the southernmost limit of this activity (Macdonald, 2003; Smith, 1994), the volume is estimated to be closer to $4,000 \mathrm{~km}^{3}$. These phonolites show sheet-like morphologies, but a definitive source for these flows has not been identified (Smith 1994). Based of the flow extent presented by Smith (1994) it is reasonable to assume that these phonolites exist within the present rift valley but are 
A. Guth, MS Thesis, 2007

buried by other flows. The only units that outcrop within the present study area that are considered part of the Plateau Phonolites are the Kapiti, Kandizi and Nairobi Phonolites, which are all preserved on the eastern rift shoulder near Nairobi.

\section{0 to $6 \mathrm{Ma}$}

Figure 17. After the early to mid-Miocene events, the volcanic activity, at least that we have evidence of, was relatively quiet until around $7 \mathrm{Ma}$ when there was another period of volcanism following the initial rift faulting that defined the western boundary. In the southern Kenya rift, the first major fault displacement was on the Naitiami fault with a movement of at least $250 \mathrm{~m}$, which was subsequently followed by $200 \mathrm{~m}$ displacements on the Sonjo and Northern Sambu faults (Crossley, 1979). The Lengitoto Trachyte and Endosapia Formation were erupted into this early rift from 5.0 to 6.9 m.y.a. Based on preserved morphology of the Lengitoto flow, it appears that these flows are elongated in a north-south direction either due to eruption from similarly oriented fissures and/or confinement by the fault scarp. The flows that erupted outside, or before, the rift seem to have a more puddle-like morphology as they were not confined and probably erupted onto gentle or flat topology.

Age dates for rocks associated with the Ol Esayeti complex indicate that this volcanic center may have started erupting around 6.7 m.y.a. (Baker et al. 1971).

\section{$6 \mathrm{Ma}$ to $3 \mathrm{Ma}$}

Figure 18. There was a second period of faulting on the Naitiami, northern Sambu, Sonjo, Lengitoto and Kirikiti faults, after which the rift was at least $450 \mathrm{~m}$ deep (Crossley 1979). There are two formations that exist on the present eastern shoulder that 
A. Guth, MS Thesis, 2007

were correlated with the Olorgesailie complex based on petrologic similarities to lavas found on the volcano (Matheson, 1966). These phonolites and nephelinitic-phonolites suggest that Olorgesailie may have started erupting around 5.8 m.y.a. (Baker et al., 1971). Additional rocks from Ol Esayeti indicate periods of eruption from 5.85 and 5.64 Ma (Baker et al. 1971) and around 3.6Ma (Baker and Mitchell, 1976). Assuming all of these age dates are accurate, then this volcanic center had around 3 million years of activity.

The Nairbobi trachytes can be seen on the eastern shoulder of the rift, probably originated from north of the study area, and are dated between 3.17-3.45 Ma (Baker et al., 1971). Within the rift up to 550m of the Kirikiti basalts were erupted, (Baker et al., 1977a), probably from fissures, between 2.5 and 3.1 Ma (Crossley, 1979).

\section{Ma to $2 \mathrm{Ma}$}

Figure 19. The first faulting to define the eastern side of the rift occurred sometime around 3Ma (Baker et al. 1977a). A trachyte from Olorgesailie was dated at 2.7Ma (Baker et al. 1971) and another Olorgesailie volcanic gave an age of 2.2 Ma (Fairhead et al., 1972). Given that the oldest flow associated with this vent is dated to 5.8Ma, this eruptive center was also active for over 3 million years like Ol Esayeti. The Singaraini basalts were the first volcanics to erupt into the newly down dropped eastern section of the rift and the lowest exposed flow examined by Baker and Mitchell (1976) was dated to 2.33 Ma. These basalts also exhibit flow elongation similar to the Lengitoto trachytes and Kirikiti basalts, and based on this similar morphology, the Singaraini basalts were probably also erupted from fissures. They were as much as 550m thick and confined by the newly formed eastern boundary fault (Baker et al. 1977a). Also around 2.3 m.y.a. (Crossley and Knight, 1981), the Mosiro trachytes were erupted in the north 
A. Guth, MS Thesis, 2007

section of the study area, were around 300m thick, and probably covered at least half of the northern rift floor (Baker et al., 1977a)..

To the west, the Kordjya basalts (2.17 Ma, Baker and Mitchell, 1976) and Ewaso Ngiro trachytes (2.1 Ma, Crossley, 1979) started erupting onto the rift floor. Ol Doinyo Sambu, a volcanic center to the west of Lake Natron in northern Tanzania and centered on the Sambu fault, erupted further basalts that overlapped onto the Kirikiti basalts around 2 m.y.a (Crossley and Knight, 1981). In addition to the continued activity of Olorgesailie, ages of 2.62 and 2.0 Ma (Fairhead et al., 1972) for Lenderut and Shombole respectively, indicate that these two volcanoes were also initiated during this time.

\section{Ma to $1.5 \mathrm{Ma}$}

Figure 20. The Limuru trachytes were at least 300m thick and flooded the northern section of the study area starting around 1.96 m.y.a. (Baker and Mitchell, 1976) and locally overflowed the eastern fault scarp and spread onto the rift shoulder (Baker et al. 1977a). Combined with the Mosiro trachytes these two trachyte flows probably

covered the entire rift floor in the northern study area (Baker et al., 1977a). The Ol Tepesi Benmoreites and Ol Keju Nero Basalts were both erupted around 1.65 Ma (Baker and Mitchell 1976) in the eastern rift floor near Olorgesailie.

To the south near Lake Natron, the Humbu sedimentary formation has been dated between 1.35 and 2Ma (Mora et al. 2003; Thouveny and Taieb, 1986) and represents the oldest dated lacustrine unit in the study area. This formation is in the Lake Natron basin and suggests that a paleolake existed during this time, although, would have been confined to the north by the larger sizes of Sambu and Shombole (Dominguez-Rodrigo et 
A. Guth, MS Thesis, 2007

al., 2001). Also, unlike the present Lake Natron, the Humbu Formation represents a freshwater deposit (Thouveny and Taieb, 1986).

\section{$1.5 \mathrm{Ma}$ to $100 \mathrm{ka}$}

Figure 21. The $\mathrm{Ol}$ Tepesi basalts were erupted between 1.6 and 1.4 Ma in the Olorgesailie area (Baker 1988). One of the most prominent volcanic formations in the present rift landscape, the Magadi Trachytes, flooded the center of the rift between Suswa in the north and Gelai in northern Tanzania (note that Suswa did not exist at this time) to a depth of at least $190 \mathrm{~m}$ starting 1.4 million years ago. These flows thicken towards the center of the rift (Baker et al. 1977a) and were probably erupted from fissures rather than any of the large central volcanoes in the area (Fairhead et al., 1972; Crossley, 1979). This was the last major eruption in the study area, and the youngest flow, which is located in the Lake Magadi area, has been dated to 780ka (Fairhead et al., 1972). This young flow intercalates with the Oloronga beds, so a large paleolake occupying the present location of Lake Magadi, must have existed at this time. It should also be noted that Bye et al., (1987) remark that this obsidian in the Oloronga beds is nearly identical to the obsidians of Ol Doinyo Nyokie. Based on this chemical similarity it is possible this obsidian flow may be from Ol Doinyo Nyokie, or rather, that Ol Doinyo Nyokie is a manifestation of the Magadi Trachyte eruptions and thus an obsidian from the main Magadi trachyte eruption would chemically resemble the obsidians from Nyokie. Other young flows from the Magadi trachytes have been dated between 0.9 and 0.7 (Baker et al., 1971) which coincides with an age of $0.66 \mathrm{Ma}$ for Nyokie (Fairhead et al., 1972).

Another large lake existed near Olorgesailie between 1 and 0.5 m.y.a. (reported in Behrensmeyer et al., 2002b) and deposited a large amount of diatomite. Hominid artifacts 
A. Guth, MS Thesis, 2007

are also associated with these lake deposits and include numerous handaxes and a partial hominid skull (Potts et al., 2004). There was a flurry of minor volcanic events around 600ka, with Ol Doinyo Nyokie, Ol Doinyo Alasho (both small trachytic centers in the rift), and the Mosiro basalts all erupting at this time. The Mau ashes, which currently blanket the rift shoulder to the west of Suswa, were also erupted during this time. A number of closely spaced grid-faults broke up the rift floor by 400ka (Baker et al., 1977a). The Suswa volcanic center started building around 240ka and eruptions continued until 100ka (Baker et al., 1988). There is evidence of some eruptive activity from Suswa being less than 100 years old, as there are some flows in the crater floor that are unvegitated, and thus must be relatively fresh (GVP website).

Details regarding the sedimentary units may be found below in the Magadi-area

\section{Sediments section.}

\section{Fault Summary}

The faulting history is an important aspect of the evolution of the rift and a summary of the reported fault movements can be seen in Table 1 below and has been plotted as displacement in meters versus time in Figure 22. In the plot, displacement on western faults are represented by the blue bars, eastern faults by the red bars, and displacements in the rift floor are represented by yellow bars. For Figure 22 the movements are binned in half million year increments, so what may be listed as several events in Table 1 below, may be represented by only one bar in Figure 22.

Understanding the timing of the faults is important as they define the rift boundaries, confine volcanic flows, create sedimentary basins, and complicate the stratigraphy and correlation efforts for the rift related geology. By narrowing the age 
A. Guth, MS Thesis, 2007

range in which the fault displacements took place in different areas, the evolution of the rift can been looked at as a series of simple steps that create a complicated final picture as in Figure 10.

Table 1: Major fault movements in the southern Kenya Rift

\begin{tabular}{|c|c|c|c|c|c|}
\hline West Fault & $\begin{array}{l}\text { Rift } \\
\text { Floor }\end{array}$ & $\begin{array}{c}\text { Eastern } \\
\text { Fault }\end{array}$ & $\begin{array}{l}\text { Age of } \\
\text { movement } \\
\text { (Ma) }\end{array}$ & $\begin{array}{l}\text { Displacement } \\
\text { (m) }\end{array}$ & Source \\
\hline Kirikiti & & & & 20 & \\
\hline \multirow{6}{*}{$\begin{array}{l}\text { Kirikiti- } \\
\text { Lengitoto- } \\
\text { Sambu }\end{array}$} & & & 0.6 & 700 & Crossley 1979 \\
\hline & $\begin{array}{l}\text { Grid } \\
\text { faults }\end{array}$ & & $0.9-0.4$ & 45 & $\begin{array}{l}\text { Baker et al. } \\
1977 \mathrm{a}\end{array}$ \\
\hline & $\begin{array}{l}\text { West of } \\
\text { Emerit }\end{array}$ & & $1.42-1.2$ & & $\begin{array}{l}\text { Baker and } \\
\text { Mitchell } 1976\end{array}$ \\
\hline & & $\begin{array}{l}\text { Kedong } \\
\text { and Kiriri }\end{array}$ & $1.65-1.91$ & & $\begin{array}{l}\text { Baker and } \\
\text { Mitchell } 1976\end{array}$ \\
\hline & & $\begin{array}{l}\text { Esayeti- } \\
\text { Kedong }\end{array}$ & $2-1.7$ & & $\begin{array}{l}\text { Baker et al. } \\
1977 \mathrm{a}\end{array}$ \\
\hline & & $\begin{array}{l}\text { Turoka- } \\
\text { Ngong }\end{array}$ & 3 & 500 & $\begin{array}{l}\text { Baker et al. } \\
1977 \mathrm{a}\end{array}$ \\
\hline $\begin{array}{l}\text { Kirikiti- } \\
\text { Enkorika }\end{array}$ & & & $5-3$ & 820 & $\begin{array}{l}\text { Baker et al. } \\
1977 \mathrm{a}\end{array}$ \\
\hline Sonjo-Sambu & & & Before $6.9 \mathrm{Ma}$ & 200 & Crossley 1979 \\
\hline Naitiami & & & Before $6.9 \mathrm{Ma}$ & 250 & Crossley 1979 \\
\hline
\end{tabular}

One of the more interesting aspects of the fault timing is that the rift did not start as simply a narrower version of the present rift geometry. There were at least 3 million years between the displacements that formed the western rift boundary and those that defined the eastern boundary. So for 3Ma, all evidence indicates that the rift existed as a half-graben. Simiyu and Keller (2001) claim that the southern and central Kenya Rift (in their paper taken to be south $1^{\circ}$ North) is dominated by asymmetric grabens that have western master faults (the western sides of the basins are deeper than the eastern sides). The development of rift segments farther to the north of the present study area may have 
A. Guth, MS Thesis, 2007

a similar evolutionary course as seen here, where the western faults move first and accommodate most of the displacement. It may be possible that the time gap between the faulting of the western and eastern boundaries of the rift may be related to the crustal thickness on the two sides of the rift, as seismic experiments indicate that the crust to the east of Lake Magadi is significantly thicker than the crust to the west $(35 \mathrm{vs} .40 \mathrm{~km}$, Prodhel et al., 1994; Khan et al., 1999). The nature of the faults on the opposing sides is also different. The major western boundary faults all experienced at least two periods of reactivation (Crossley, 1979) while some of the large boundary faults on the east only moved once. There is at least 1400m displacement on the western Sambu and Kirikiti faults, meaning that the basement rocks cannot be any higher than sea level. However, metamorphic rocks are much higher to the east, as the Singaraini Basalts are thought to have been erupted directly onto the metamorphic rocks and may be as thin as $60 \mathrm{~m}$ near their eastern boundary (Baker, 1963). In fact, Baker (1963) mapped an outcrop of metamorphic rock at 1150-1200m elevation within the rift floor (Lebor, plane-table survey station) that is surrounded by exposures of Singaraini Basalt.

Baker et al. (1977a) provide discussion on how stress fields affect whether magma intrusion or faulting occurs. They note that fields of stability for intrusion and faulting are generally separate and there is "no condition under which magma can ascend and normal faulting can occur simultaneously" which explains the general observation that episodes of faulting and eruption alternate. This is discussed again in the Volume Estimates section below.

While the study area seams seismically and volcanically quiet at the present, a study done by Ibs-von Seht et al., (2001) recorded an average of 10 micro-earthquakes a 
A. Guth, MS Thesis, 2007

day over a period of 8 months. All originated from depths greater than $10 \mathrm{~km}$, with a significant amount of activity occurring down to $22 \mathrm{~km}$. An earthquake swarm was also recorded by this team between May and June 1998 where over 300 events were recorded per day and mapped epicenters traced a linear feature that is in the same strike direction as the grid faults. One of the events associated with the swarm produced and a surface crack to the northeast of Magadi that was several kilometers long and had vertical and horizontal displacements up to $30 \mathrm{~cm}$. In addition to seismic activity along the grid faults, some micro-quakes could also be associated with the Nguruman escarpment faults.

\section{Volume estimates}

A plot of erupted volcanic volume versus time can be seen in Figure 23 (the same plot can be seen in the paleomap images, Figures 16-21, with the data for the different time spans highlighted). Three different plots were made, one using areas measured directly from the digital geologic map (i.e., the exposed surface area), one using estimated areas of probable extent and the third showing cumulative volume. The Plateau Phonolites dominate in volume and were left out of the cumulative volume measure. It is interesting to note that it was not until recently that volcanic volume exceeded that extruded during the massive pre-rift phonolite eruptions. Additionally, no other flow of nearly that magnitude occurred in this area. In comparison, the other events were small and localized and it took around 10 million years before these small events surpassed the Plateau Phonolites in volume.

To facilitate analysis of the contribution of different volcanic rock types towards the overall erupted volume, Figure 24 was created. It is essentially the same as Figure 23, in that the bars represent volume versus time, except that the bars have been subdivided 
A. Guth, MS Thesis, 2007

to show the contributions of the different petrologic groups. As can be clearly seen from this figure, after the initial eruption of the Plateau Phonolites, phonolitic eruptions were an insignificant portion of the material erupted over the next 13 million years. It also demonstrates quite well the shifts in erupted material over time (with a seeming trend here of phonolites giving way to basalts, which then get surpassed by trachytes).

A number of authors have provided volume estimates for different units, total volume for sections of the rift, and even estimates of the required source material to create all the flows. A comparison of values given by different authors can be seen in Table 2 below. It should be noted that these different papers look at areas of differing sizes for their calculations. Baker et al. (1988) use the area from the equator to $200 \mathrm{~km}$ south (to just south of Olorgesailie), Baker and Mitchell (1976) examine the area from $1^{\circ}$ South to approximately $2.25^{\circ}$ South for their volume estimations, and the volumes reported Macdonald (2003) are for the entire Kenya Rift.

The main area of study in this report is from $1^{\circ}$ South to the Kenya-Tanzania border and thus corresponds most closely with the area considered by Baker and Mitchell (1976). However, units that were easily identifiable that extended out of the defined study area for this study were mapped in their entirety, and an effort was made to get a total estimate of the plateau phonolites despite their existence well outside of the study area in order to be comparable to estimates presented by Macdonald 2003.

It can be seen that there is a large discrepancy between the volume estimates obtained by Baker and Mitchell (1976) and this author for the Limuru trachytes. Based on Baker et al. (1988), it appears that the Mosiro trachytes, Gesumeti trachytes, and the lavas 
A. Guth, MS Thesis, 2007

of Saggerson's (1971) Middle-trachyte division (the Kabete, Karura and Tigoni

trachytes) were all correlated with the Limuru trachytes.

Table 2: estimated volumes in $\mathrm{km}^{3}$, for various units and total volcanics from different authors including data from this study. Note that the Totals may not equal the sum of the boxes above, as a number of basalt and trachyte flows were not directly comparable to calculations done by previous authors, but are tallied into the totals to represent activity in the study area.

\begin{tabular}{|c|c|c|c|c|}
\hline & $\begin{array}{c}\text { Baker et al. } \\
1988 \text { (max } \\
\text { estimate) }\end{array}$ & $\begin{array}{c}\text { Baker and } \\
\text { Mitchell } \\
1976\end{array}$ & $\begin{array}{c}\text { Reported in } \\
\text { Macdonald } \\
2003\end{array}$ & $\begin{array}{c}\text { Guth } 2007 \text { (max } \\
\text { estimate) }\end{array}$ \\
\hline Limuru Trachyte & 1230 & 1230 & & 560 \\
\hline Plateau Trachyte & 540 & 540 & & 475 \\
\hline $\begin{array}{l}\text { Kordjya, Ol Tepesi \& } \\
\text { Ol Keju Nero Basalts }\end{array}$ & & 340 & & 220 \\
\hline Singaraini Basalt & & 330 & & 685 \\
\hline Plateau Phonolites & & & $\begin{array}{c}25,000- \\
50,000\end{array}$ & 40,000 \\
\hline Total basalt & 700 & 670 & & 2360 \\
\hline Total trachyte & 6500 & 1770 & & 1860 \\
\hline $\begin{array}{l}\text { Total basalts }+ \\
\text { trachytes }\end{array}$ & 7200 & 2440 & & 4220 \\
\hline
\end{tabular}

Adding those units to the volume calculation for the Limuru trachytes would bring the total volume to $1060 \mathrm{~km}^{3}$ which is closer to the estimate provided by Baker and Mitchell (1976). These authors provide a breakdown of the values used in their volume calculations, and while their approximate outcrop area of $1,200 \mathrm{~km}^{2}$ is close to the mapped area of about $930 \mathrm{~km}^{2}$ (for the Limuru trachytes alone) in this study, they estimated the total extent to be $4,100 \mathrm{~km}^{2}$. Baker and Mitchell claim that their estimated volume is based on the assumption that the flood lavas spread across the entire width of 
A. Guth, MS Thesis, 2007

the inner graben of the rift valley. Taking the other units Baker and Mitchell (1976)

correlated with the Limuru trachytes for their volume calculations into account, the maximum total extent obtained here is about $3800 \mathrm{~km}^{2}$, which is in close agreement with the value they used.

It can also be seen that the volume estimates made by Baker and Mitchell (1976) for the $\mathrm{Ol}$ Tepesi, Kordjya and $\mathrm{Ol} \mathrm{Keju} \mathrm{Nero} \mathrm{basalts} \mathrm{combined} \mathrm{is} \mathrm{larger} \mathrm{than} \mathrm{the} \mathrm{total} \mathrm{of}$ the values obtained in this study. However, by examining their geologic map for the southern Kenya Rift, it can be seen that units later identified by Crossley (1979) as the Ewaso Ngiro and North Kordjya trachyte, and by Crossley and Knight (1981) as the Mosiro trachytes, are all included as part of the volume calculation made by Baker and Mitchell for the combined basalts.

In addition to estimating volumes of outcropped or erupted volcanics, several authors have attempted to estimate the amount of parental magma needed to produce the volumes seen at the surface. Baker and Mitchell (1976) state that 19 parts of basaltic parental magma are needed to make one part trachyte flood lava via fractionation. So, $34,000 \mathrm{~km}^{3}$ of basaltic magma would be needed to account for the $1800 \mathrm{~km}^{3}$ of trachyte they estimated exists in the Southern Kenya Rift. A positive gravity anomaly and high Pwave velocities along the axis of the rift seemed to agree with a body of basaltic rocks under the rift. Baker et al. (1977b) suggested that the parental magma would likely exist as a body $15 \mathrm{~km}$ wide, $20 \mathrm{~km}$ deep and $100 \mathrm{~km}$ long under the axis of the rift, and that eruptions from this magma body would result in gravity faulting of the reservoir's roof. Baker et al. (1988) suggest that an order of magnitude more basaltic parental magma is needed assuming fractionation, and, knowing that, the source would equate to a body 
A. Guth, MS Thesis, 2007

70km wide, $86 \mathrm{~km}$ deep and $200 \mathrm{~km}$ long. Please see the discussion in the Volcanic gas estimates section for a further discussion of this supposed axial magma body.

According to Baker et al. (1977b) geophysical and geochemical evidence support the idea that magma intrusion into the crust accompanied rift formation, but, as noted above in the Fault Summary section, it was shown that, based on stress calculations, that magma ascension and normal faulting cannot occur simultaneously. Figure 25 shows the volume calculations and fault displacements on the same plot. However, the alternation of volcanism and periods of faulting mentioned by Baker et al., (1977a) cannot be seen as it is suspected that the bin size of $0.5 \mathrm{Ma}$ used to create the plot is too large to resolve a pattern.

\section{Magadi-area Sediments}

Sedimentary units comprise only a minor part of the rift fill, both in terms of age, with the oldest lacustrine units of the area dating back to $1.35 \mathrm{Ma}$ in the Natron basin, (Thouveny and Taieb, 1986; Mora et al., 2003) and $780 \mathrm{ka}$ in the Magadi basin, and volume. The Kenya rift is dominated by an extensive series of volcanics, with the oldest being around $15 \mathrm{Ma}$, that are related to the doming, and eventual rifting event that lead to the modern landscape. The sedimentary units are comparatively thin and recent, are mainly confined to grabens, and overlie these volcanic rocks. Due to grid faulting and sometimes patchy preservation, determining the chronology of these sediments is difficult and the chronological order of some of these units has been shuffled several times since Baker's original attempt in 1958.

Copyright (C) Alexandria L. Guth 
A. Guth, MS Thesis, 2007

Sedimentary formations around Lake Magadi include the Evaporite Series, High Magadi Beds, Green Beds, and Oloronga Beds, listed from youngest to oldest. The ages

for each of these units, and how they were determined, can be seen in Table 3 on page 43.

The oldest lake deposits that occur in the Magadi basin are the Oloronga beds.

These contain tuffs, carbonates and cherts and overlie the Magadi Trachytes (Baker, 1958). There is an area to the northeast of Lake Magadi where a trachyte flow was noted to overlie some Oloronga deposits (Eugster, 1980) and the contact between the flow and the lake beds was chilled to produce a 1m layer of glass which was dated by Fairhead et al. (1972). The obtained date of 780ka serves as a key date for placing the end of the Magadi Trachyte activity and the initiation of lake sedimentation in the basin. A young date on these lake beds of 300ka is presented by Behr and Röhricht (2000) from U/Th dating of a Hippopotamus tooth. These lake beds feature two carbonate boxwork layers (Potts et al. 1988) which Baker (1958) described as "honeycomb rock". While the lake deposits around Olorgesailie to the northeast have been known for years for the hominid artifacts found there, hominid artifacts have too been found in the Oloronga beds (Shipman et al., 1983; Potts et al., 1988; Potts and Deino, 1995) within the locality known as Lainyamok that is northwest of Lake Magadi (Figure 12, denoted by the star). At this site hominid teeth, a femur and Acheulian tools have been found along with a number of animal remains. Potts et al. (1988) provide a fairly detailed description of the Oloronga Beds associated with the Lainyamok site, including a stratigraphic section, and lists of the fauna found at this locality are provided by Potts et al. (1988) and Shipman et al. (1983). 
A. Guth, MS Thesis, 2007

The Green Beds are confined to the Magadi trough and the cherts they contain have been the subject of numerous studies (Eugster, 1967, 1969, 1980; Schubel and Simonson, 1990; Behr and Röhricht 2000; Behr, 2002). This formation was originally named the "Chert Series" by Baker (1958) but was then abandoned as a formal formation by Eugster (1969, 1980), who divided the cherts between the High Magadi and Oloronga beds. Recent papers (Behr and Röhricht, 2000; Behr, 2002) have again established the Chert Series as its own formation based on age dates intermediate to the Oloronga and High Magadi beds, and have renamed them as the Green Beds due to the greenish color of the silts and tuffs in this formation (Behr and Röhricht, 2000). This definition and naming has been retained in this report.

The most recent high lake level is represented by layers of brown silts and clays which belong to the High Magadi beds. Baker (1958) suggests that these deposits probably covered the entire basin, most of which have since been removed by erosion. These beds also include reworked sediments from the underlying Oloronga beds, and thus distinguishing between the two can be difficult. The High Magadi beds also contain the magadiite layers studied extensively by Eugster (1967, 1969, 1980), several layers containing tilapia remains (which are significantly larger than the stunted fish that live in today's lake) and, as noted by Baker (1958), some instances of hollow kunkar tubes which most likely formed around stems and branches of plants. Similar tubes were noticed during the 2006 field season on the track west of the North-West Lagoons. The High Magadi beds also host later stone age artifacts at a site termed Olkena located on the, mainly trachyte, peninsula that divides Lake Magadi (Barthelme et al., 2003). Blades, scrapers, micro-drills, grindstones, eggshell beads and burnt land-snail shells were found 
A. Guth, MS Thesis, 2007

associated with a sand and gravel unit located between the Oloronga and High Magadi beds. The layer containing the artifacts was interpreted by Barthelme et al. (2003) as being from a fluvial environment during a cooler, drier period with lower lake levels (compared to Lakes Oloronga and High Magadi). Also found by these authors was a burial cairn in the same area made of lava blocks, but unfortunately an age date could not be obtained to link it with the artifacts.

The Evaporite Series is currently being deposited, and is represented by a large trona deposit (hydrated sodium bicarbonate carbonate, $\mathrm{Na}_{3} \mathrm{HCO}_{3} \mathrm{CO}_{3} \cdot 2 \mathrm{H}_{2} \mathrm{O}$ ) that occupies the center of the Lake Magadi basin. This deposit is up to 40m thick and has been mined by the Magadi Soda Company since 1911 (Magadi Soda website). Present practice is to mine one area of the deposit for a number of years and then to move the mining area. The previously mined area will recrystallize due to the continued input of solutes from the hot springs, and over time, the pit created by mineral extraction can be observed to close (Figure 26). This area is then again mineable, and is of even higher quality then before due having more consistent crystal size and lack of interbedded muds found in the original deposits.

Outside of the Magadi area, there are two notable sedimentary deposits located in the present study area. In the Legemunge basin there are deposits associated with the previous Lake Olorgesailie (Gregory 1921, attributed these beds to a 'Lake Kamasia'; Reported in Owen and Renault, 2000) that existed to the north of the extinct Olorgesailie volcano. These lake beds are dated between approximately $1-0.5 \mathrm{Ma}$ (reported in Behrensmeyer et al., 2002) and contain numerous Acheulian aged hominid handaxes, and a large deposit of diatomite. 
A. Guth, MS Thesis, 2007

Table 3: Sedimentary and Volcanic formations of the Lake Magadi basin and their ages

\begin{tabular}{|c|c|c|c|c|}
\hline Unit & What was dated & $\begin{array}{l}\text { Dating } \\
\text { method }\end{array}$ & Age & Source \\
\hline \multirow{5}{*}{ 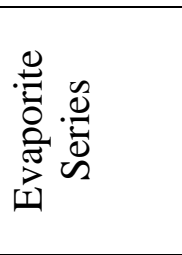 } & Tilapia & $14 \mathrm{C}$ & $4650+/-400$ & 1 \\
\hline & Oncoids & & 5000 & $2^{\wedge}$ \\
\hline & Trona & & 7100 & $3^{\wedge}$ \\
\hline & Trona & & 9120 & 2 \\
\hline & Trona & & 10,010 & $2^{\wedge}$ \\
\hline \multirow{8}{*}{ 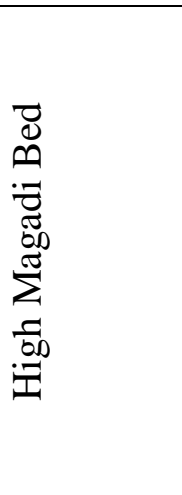 } & Na-silicate & U/Th & $6000+/-3000$ & 4 \\
\hline & & & 9310 & $2^{\wedge}$ \\
\hline & Ostrich eggshell & ${ }^{14} \mathrm{C}^{*}$ & $9940+/-60$ & 5 \\
\hline & Ostrich eggshell & ${ }^{14} \mathrm{C}^{*}$ & $10,300+/-100$ & 5 \\
\hline & $\begin{array}{l}\text { Total Organic Matter } \\
\text { (TOM) }\end{array}$ & ${ }^{14} \mathrm{C}$ AMS & $10,800+/-120$ & 6 \\
\hline & TOM & ${ }^{14} \mathrm{C}$ AMS & $12,090+/-120$ & 6 \\
\hline & & & 14,515 & 2 \\
\hline & $\begin{array}{l}\text { TOM + authigeneous } \\
\text { zeolites }\end{array}$ & $\mathrm{U} / \mathrm{Th}$ & $\begin{array}{l}23,700+/- \\
6000\end{array}$ & $6^{\wedge}$ \\
\hline \multirow{2}{*}{ Dृ } & $\begin{array}{l}\text { TOM + authigeneous } \\
\text { zeolites }\end{array}$ & $\mathrm{U} / \mathrm{Th}$ & $\begin{array}{l}40,000+/- \\
6500\end{array}$ & $6^{\wedge}$ \\
\hline & Lower chert & $\mathrm{U} / \mathrm{Th}$ & $\begin{array}{l}98,500+/- \\
20,000\end{array}$ & 4 \\
\hline \multirow{3}{*}{ 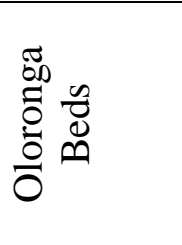 } & Hippopotamus tooth & U/Th & 300,000 & $3^{\wedge}$ \\
\hline & $\begin{array}{l}\text { Lainyamok Khaki } \\
\text { layer } 1, \text { An-feldspar }\end{array}$ & $\begin{array}{l}40 \mathrm{Ar} / 39 \mathrm{Ar} \\
\text { isochron }\end{array}$ & $\begin{array}{l}330,000+/- \\
6000\end{array}$ & 7 \\
\hline & $\begin{array}{l}\text { Lainyamok Khaki } \\
\text { layer } 2, \text { An-feldspar }\end{array}$ & $\begin{array}{l}40 \mathrm{Ar} / 39 \mathrm{Ar} \\
\text { isochron }\end{array}$ & $\begin{array}{l}392,000+/- \\
4000\end{array}$ & 7 \\
\hline Nyokie & Obsidian & $\mathrm{K} / \mathrm{Ar}$ & $0.66+/-0.04$ & 8 \\
\hline \multirow{2}{*}{$\begin{array}{l}\text { Magadi } \\
\text { Trachyte }\end{array}$} & Obsidian & $\mathrm{K} / \mathrm{Ar}$ & $0.78+/-0.04$ & 8 \\
\hline & anorthoclase & $\mathrm{K} / \mathrm{Ar}$ & $0.92+/-0.01$ & 7 \\
\hline \multirow{3}{*}{$\begin{array}{c}\text { Kordjya } \\
\text { Basalt }\end{array}$} & & $\mathrm{K} / \mathrm{Ar}$ & $1.66+/-0.05$ & 9 \\
\hline & & $\mathrm{K} / \mathrm{Ar}$ & $1.76+/-0.06$ & 9 \\
\hline & & $\mathrm{K} / \mathrm{Ar}$ & $2.17+/-0.10$ & 9 \\
\hline \multirow{2}{*}{$\begin{array}{l}\text { Singaraini } \\
\text { Basalt }\end{array}$} & & $\mathrm{K} / \mathrm{Ar}$ & $2.31+/-0.10$ & 9 \\
\hline & & $\mathrm{K} / \mathrm{Ar}$ & $2.33+/-0.09$ & 9 \\
\hline \multirow{4}{*}{$\begin{array}{l}\text { Kirikiti } \\
\text { Basalt }\end{array}$} & & $\mathrm{K} / \mathrm{Ar}$ & $2.5+/-0.2$ & 10 \\
\hline & & $\mathrm{K} / \mathrm{Ar}$ & $2.68+/-0.16$ & 9 \\
\hline & & $\mathrm{K} / \mathrm{Ar}$ & $2.7+/-0.2$ & 10 \\
\hline & & $\mathrm{K} / \mathrm{Ar}$ & $3.1+/-0.2$ & 9 \\
\hline
\end{tabular}

* uncalibrated, $\wedge$ reported in

1- Hillaire-Marcel et al., 1986, 2- Behr, 2002, 3- Behr and Rohricht, 2000, 4- Goetz and Hillaire-Marcel, 1992, 5- Barthelme et al., 2003, 6- Williamson et al., 1993, 7- Potts and Deino, 1995, 8- Fairhead et al., 1972, 9- Baker and Mitchell, 1976, 10- Crossley, 1979 
A. Guth, MS Thesis, 2007

In addition to the handaxes, which have been known for decades, a partial skull (possibly a small Homo erectus that lived between 0.97 and $0.90 \mathrm{Ma}$ ) was recently reported by Potts et al. (2004) and found in association with the handaxes. Due to the hominid artifacts and remains, these lake deposits have been the subject of a number of papers (Potts et al., 2004; Behrensmeyer et al., 2002; Owen and Renaut, 1981, etc...) and excavations continue at present.

In the $\mathrm{Ol}$ Tepesi Basin to the east of Legemunge, a very distinctive deposit from what Baker and Mitchell (1976) refer to as the Kedong Flood can be seen. This flood is thought to have resulted from the catastrophic release of water from the Kedong Basin near Suswa about 100ka and has been dated based on the lava flows that show scouring versus those that do not. This unit is very distinctive in the satellite images, but not as obvious when driving across the plain.

One additional unit of interest was noted in Prodehl et al. (1997) although it was insufficiently described to identify. While attempting to drill for a seismic shot point close to Lake Magadi, the team kept running into a very soft layer at shallow depths (depth was not quantified) so the drilling was relocated to $30 \mathrm{~m}$ above the lake on one of the trachyte horsts. Drilling was accomplished through 30 meters of (presumably) trachyte before that soft layer was again encountered. No inter-volcanic sediments are described for the area, however, it may be possible that the drilling site was on one of the young lava flows that over-rode the old lake deposits like to the NE of Magadi (as dated by Fairhead et al., 1972 and as described by Eugster, 1980). It is interesting that the initial drilling attempts were at current lake level, they gained 30m in elevation and hit the same 
A. Guth, MS Thesis, 2007

soft layer 30m down which seems to indicate the trachyte flowed over a lake flat similar to what exists today. However, that still begs the question of what the soft layer was. 
A. Guth, MS Thesis, 2007

\section{Part II: A Characterization of the Lake Magadi Area}

\section{Lagoon Water analysis}

The brines surrounding Lake Magadi have been of interest to scientists for a number of decades. Stevens did a number of water analyses for the spring brines (reported in Baker 1958) and calculated the input of calcium carbonate to the lake basin from the brines. Eugster's "Chemistry and origin of the brines of Lake Magadi” (1970) delves into the aqueous chemistry of the lake brines and rivers. In an earlier 1968 paper, Eugster and Jones note that the chemistry of the hotsprings had not changed in the 34 years since Stevens' report, and Stevens had reported that the springs had not changed in the 20 years prior to his paper. It should be mentioned however, that in a more recent report done to evaluate the geothermal potential at Magadi (McNitt et al., 1989), an unpublished work by K. Crane is said to have concluded that temperature and flow rates of the springs show both cyclic and progressive trends. These changes are linked to earthquake activity and the suspected opening or closing of upflow channels. Crane (1981) mentions that despite the claims by Eugster (1970) and Baker (1958), Stevens relayed through personal communication to her that there were indeed dramatic changes in temperature and flow rates of the springs. This paper by Crane makes mention of several interesting phenomena that are not known to be described elsewhere: an unusual feature termed the "bottomless pit" that existed before 1933, the fact that the Bird Rock

Lagoon springs were much more active before 1948, and that in 1958 mud volcanoes and boiling geysers were noted near the south end of the lake. These events are linked by Crane to seismic activity in the area, rather than volcanic events. While Crane focused on 
A. Guth, MS Thesis, 2007

correlations of seismic events over 5 on the Mercalli scale, as it was noted before, Ibsvon Seht et al. (2001) recorded a number of micro-earthquakes over the span of 8 months which indicates a near constant seismicity of the region. With this constant background activity, it could be possible that the springs may show gradual changes due to constant micro-quake activity, but such small changes would require careful monitoring of the springs over a long period along in addition to monitoring of micro-quakes.

Based on the isotopic evidence, Eugster (1970) concluded that the bulk of the thermal waters are meteoric in origin and resulting salinity is a function of basin size, depth of circulation and the total inflow. Lake Magadi has a large evaporation area and probably a deep and slow circulation. Helium isotope analyses on the brines done by $\mathrm{H}$. Craig (reported in McNitt et al., 1989) suggests that hot, mantle derived, gases are rising from depth and mixing with the waters supplying Little Magadi springs (those springs are supposed to have the deepest source). Craig suggests that the Little Magadi springs contain $46-47 \%$ mantle derived helium, while the sample from the southern end of Magadi had approximately 25-26\% mantle helium. Also, the temperature of the Little Magadi brines at the surface springs is about twice that of the brines at the south end of Magadi (over $80^{\circ} \mathrm{C}$ versus around $40^{\circ} \mathrm{C}$ ). There are not enough samples to draw significant conclusions, but it may be interesting to test if there is a general correlation between temperature of spring water and mantle derived helium (i.e. hotter springs would be expected to have a more direct connection with the heat source/ magma body and thus more mantle derived Helium, while cooler springs might be expected to undergo more dilution and thus have lower values of mantle derived Helium). Additional stable isotope analyses also indicate a difference between the spring sources at the southern end of 
A. Guth, MS Thesis, 2007

Magadi and those at Little Magadi. This isotopic evidence indicates either different brine origins or different mixing histories for the brines.

A variety of authors have conducted and presented water analyses for Lake Magadi. With the findings reported in McNitt et al. (1989) and by Crane (1981), it seems plausible that the spring chemistry may not be as stable as originally thought considering the temperature and flow rates have been seen to change. A brief comparison of the chemical composition of the spring waters based on analyses done by Stevens (1927 Unpublished, reported in Baker 1958), Eugster (1970) and Wilson et al. (2004) can be found below in Table 4. While these authors analyzed for a number of chemical species, a short subset showing the $\left[\mathrm{Na}^{+}\right]$and $\left[\mathrm{Cl}^{-}\right]$was selected to allow for quick comparison.

As can be seen in Table 4 some springs yield pretty consistent measurements over the past 70-odd years such as the Fish Springs, South Western, and North West Lagoons. The others seem to vary quite a bit, but this may be due to various errors rather than actual changes in the springs. For example, Wilson et al. (2004) use a different naming scheme when referring to the springs/lagoons than do the geology papers, so exact correlation with individual springs is difficult. Also, it appears that the waters measured by Wilson et al. (2004) are those where tilapia were found living, and thus would not be sampled directly at a spring outflow, and in cases like Graham's Lagoon, Wilson noted that the water in the lagoon was layered due to water entering from two chemically distinct springs. One was hot and alkaline $\left(45.3^{\circ} \mathrm{C}, 4500 \mathrm{mmol} / \mathrm{L} \mathrm{Na}+, 1283 \mathrm{mmol} / \mathrm{L} \mathrm{Cl}-\right.$ ), while the other was cooler and fresher $\left(37^{\circ} \mathrm{C}, 102 \mathrm{mmol} / \mathrm{L} \mathrm{Na}+, 20 \mathrm{mmol} / \mathrm{L} \mathrm{Cl}-\right)$. Thus the waters that the fish were living in were a mixture of these, and based on the 
A. Guth, MS Thesis, 2007

temperatures and salinities, the hotter of the two springs had not been reported by the

other authors.

Table 4: Comparison of $\left[\mathrm{Na}^{+}\right]$and $\left[\mathrm{Cl}^{-}\right]$in Spring Waters at Lake Magadi Kenya. Values are expressed in mmol/L. Stevens (1932) did not provide totals for the sodium and chlorine ions, so values presented here are summations from measured species containing these ions.

\begin{tabular}{|c|c|c|c|c|c|c|c|c|c|c|c|c|c|c|c|}
\hline \multirow{3}{*}{ 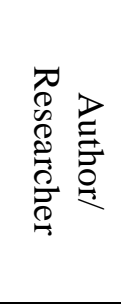 } & \multirow{3}{*}{$\underset{\overbrace{}}{\stackrel{8}{ٌ}}$} & \multicolumn{14}{|c|}{ Spring } \\
\hline & & \multicolumn{2}{|c|}{ 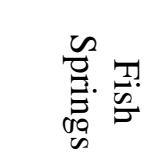 } & \multicolumn{2}{|r|}{ 象 } & \multicolumn{2}{|c|}{ 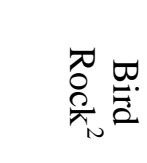 } & \multicolumn{2}{|c|}{ 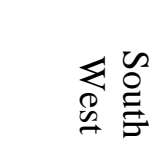 } & \multicolumn{2}{|r|}{ 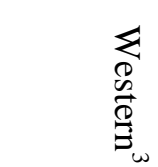 } & \multicolumn{2}{|c|}{ 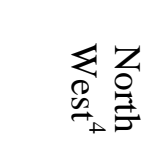 } & \multicolumn{2}{|c|}{ 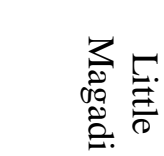 } \\
\hline & & $\mathrm{Na}^{+}$ & $\mathrm{Cl}^{-}$ & $\mathrm{Na}$ & $\mathrm{Cl}$ & $\mathrm{Na}^{+}$ & $\mathrm{Cl}^{-}$ & $\mathrm{Na}^{+}$ & $\mathrm{Cl}^{-}$ & $\mathrm{Na}^{+}$ & $\mathrm{Cl}^{-}$ & $\mathrm{Na}^{+}$ & $\mathrm{Cl}^{-}$ & $\mathrm{Na}^{+}$ & $\mathrm{Cl}^{-}$ \\
\hline Wilson & 2004 & 335 & 113 & 978 & 693 & 326 & 203 & 454 & 190 & 183 & 46 & 390 & 156 & 372 & 192 \\
\hline Jones & 1977 & 330 & 102 & 171 & 44 & 685 & 222 & 583 & 183 & 436 & 138 & 356 & 112 & 2390 & 807 \\
\hline Stevens & 1932 & 335 & 103 & 570 & 180 & 521 & 267 & 566 & 180 & 283 & 83 & 400 & 126 & 511 & 158 \\
\hline
\end{tabular}

*Note: The spring names used are those commonly used by geologists and are the names shown in one of Baker's sketch maps (1958). However, the names used by Wilson et al. (2004) differ in some cases and correlations made are noted here:

1: Sports Club Lagoon

2: South East Lagoon

3: Wilson Lagoon

4: Western Lagoon

Direct spring and lagoon comparison is further made difficult by the number of small seeps and springs in an area, the drastic change in salinity and temperature that can occur in a short distance and the fact that the lagoons (such as Graham's) can have distinct and well developed density layers in water depths of only $4 \mathrm{~cm}$ (Wilson et al. 2004 provide an interesting anecdote on how they discovered that this was the case). Trying to compare spring and lagoon composition over time would require careful and consistent measurements preferably by one investigatory team, or a group of researches that agree to define and sample the waters in the same manner. 
A. Guth, MS Thesis, 2007

\section{Volcanic gas estimates}

As noted above in the Water analysis section, the helium ratios seen in the hotsprings around Lake Magadi indicate some input of mantle-derived gases. Based on the average gas compositions outgassed by magmas (Symonds et al., 1994), magmaderived carbon would also be expected in the spring waters.

The axial gravity high used by Baker et al. (1977b, 1988) to support the existence of a parental magma body under the rift has been given further consideration with the recent seismic projects, such as the KRISP (Kenya Rift International Seismic Project) studies (Prodehl et al., 1997; Simiyu and Keller, 1998, 2001; Khan et al., 1999) in the southern Kenya Rift which have allowed for imaging of the subsurface. The axial gravity high has been noted since 1972 (Darracott et al.) and has been modeled since then by a variety of authors (Baker et al., 1977b, 1988; Swain, reported in Macdonald 2003) as resulting from a massive dike injection zone, which is expected to occupy $22-26 \%$ (9-10 $\mathrm{km}$ ) of the rift width and go down $22 \mathrm{~km}$ to possibly contain $135,000 \mathrm{~km}^{3}$ of basaltic material (Swain, reported in Macdonald 2003). This seems to be in close agreement with the volume estimation made by Baker et al. (1988) but has dimensions closer to that estimated by Baker and Mitchell (1976). However, Simiyu and Keller (1998) argue that there is no evidence from the KRISP studies to support the presence of crustal-scale dikes and that most of the gravity and seismic data can be explained by the presence of an intrarift horst. At Magadi, this horst divides the rift valley into 2 basins, with the western basin being $3.5 \mathrm{~km}$ deep and the eastern one being only $2.0 \mathrm{~km}$ deep. Simuyu and Keller do not argue against the presence of dykes in the crust, and indeed they should exist 
A. Guth, MS Thesis, 2007

given the magnitude of the volcanism present, only that they are not the major cause of the gravity anomalies as previously thought.

Regardless of the cause of the gravity anomaly, it is generally accepted that there are intrusive bodies of some magnitude within the crust. In addition to dikes and intrusive bodies within the crust, underplating of large volumes of magmatic material near the Moho between Lakes Baringo and Magadi is expected, and would explain why the expected crustal thinning is not readily seen on seismic studies as mentioned in Prodehl et al., 1997 (Simiyu and Keller, 2001). A seismic tomography study of the Magadi area presented by Green et al. (1991) supports the presence of gabbroic intrusions between 10$35 \mathrm{~km}$ depth. For comparison, the Moho is expected to be around $35 \mathrm{~km}$ depth in the Magadi region (Prodehl et al., 1997). Keranen et al. (2004) performed a similar seismic tomography study in the Main Ethiopian Rift as part of the EAGLE project (Maguire et al., 2003) and also imaged high velocity bodies along the rift axis at $10 \mathrm{~km}$ depth that were interpreted as gabbroic intrusions. It is thought that these large mafic bodies under the rift axis may be the precursors to forming seafloor spreading ridges. Importantly for volcanic gas estimates, Keranen et al. (2004) conclude that the crust overlying the magma bodies can be at maximum $30 \%$ dikes.

Gerlach (1989) estimated that the initial $\mathrm{CO}_{2}$ composition of basalts in the Afar region (before any degassing at depth) was $0.12 \mathrm{wt} \%$ and that degassing could occur at depths less than $11 \mathrm{~km}$. Approximately $85 \%$ of that $\mathrm{CO}_{2}$ could be degassed at depth. Using these figures and an estimated basalt source $2.7 \mathrm{~km}$ wide (derived from estimating that the width of $9 \mathrm{~km}$ presented in Macdonald, 2003, contained at maximum $30 \%$ dikes as claimed by Keranen et al., 2004), $10 \mathrm{~km}$ deep and running the length of the Magadi 
A. Guth, MS Thesis, 2007

basin $(35.5 \mathrm{~km})$, a potential maximum source of carbon can be (very roughly) estimated. This amount of magma under Magadi has the potential to release approximately $6 \times 10^{13}$ moles of carbon through degassing (calculations can be seen in Appendix G). The general idea is that these magmas degass at depth, and these gases rise through fissures and interact with the ground waters. Bailey and Macdonald (1987) comment on the high $\mathrm{CO}_{2}$ flux through the Kenya rift and mention that carbon dioxide leaks from the entire length of the rift. Additionally, unlike normal volcanoes where $\mathrm{H}_{2} \mathrm{O}$ is the dominant gas species, Bailey and Macdonald (1987) also note that at volcanoes like Nyiragongo and Ol Doinyo Lengai, which are both situated in the rift, $\mathrm{CO}_{2}$ is the dominant gas. An influx of $\mathrm{CO}_{2}$ will acidify waters through the formation of carbonic acid which will then leach minerals from the surrounding rocks as the waters ascend. The alkali volcanics that are common in the Southern Kenya Rift are higher in sodium, and the leaching of these volcanics by acidified waters may explain the alkaline waters of many of the rift lakes.

It is also of interest to estimate the amount of carbon currently locked away in the trona deposits of Magadi. With an area of $77.7 \mathrm{~km}^{2}$ and an estimated average trona thickness of $25 \mathrm{~m}$, there are about $3.7 \times 10^{13}$ moles of carbon stored in a deposit of this size. While these are all rough estimates, it seems likely that the magma under Magadi could produce more than enough $\mathrm{CO}_{2}$ to account for all the trona in the basin.

Based on the helium gas analyses done by H. Craig (reported in McNitt et al., 1989), it seems likely that the hottest brines, which also have the largest amount of mantle-derived helium, are from waters with a more direct connection to the magmatic heat source at depth than the cooler springs with less mantle-derived helium. These 
A. Guth, MS Thesis, 2007

cooler springs would probably experience more mixing with meteoric waters that would simultaneously decrease the temperature and alter the helium ratio.

While there is some debate about the size, shape and placement of magmatic intrusions in the crust (Baker et al., 1977b, 1988; Fairhead and Girdler, 1972; Green et al., 1991; Ibs-von Seht et al., 2001; Keranen et al., 2004; Simiyu and Keller 1998, 2001; etc...) no author totally discounts their presence as the amount of surface volcanism requires that there be magmatic alterations of the crust; it is simply the scale that is under debate. For simplicity, the measurements given in Macdonald (2003) were used in the calculations and modified to account for the estimation made by Keranen et al. (2004) that the crust above the main magmatic bodies (which are situated at, or below, the limit for degassing to occur) can contain, at most, $30 \%$ dikes.

\section{Lake Magadi Biology}

Lake Magadi has also become a site for recent numerous studies on extremophile/alkaphile bacteria living in the lake. Dubinin et al. (1995) collected and cultured microbes from Magadi, and found that a number of alkaliphilic cyanobacteria, mainly from the genus Spirulina, lived in the lake waters. A list of the bacteria and diatoms that have been noted to exist in Lake Magadi in both modern and ancient times,

can be seen in Appendix H. A similar listing was created by Baumgarte (2003) and, being a Doctoral dissertation, provides a comprehensive look at the microbes of soda lakes, with examples from Lake Magadi being discussed explicitly, in her introductory chapters.

Dubinin et al. (1995) present a finding of particular interest that some unicellular forms of cyanobacteria undergo significant morphological changes under different environmental conditions. Changes that were induced by changing environment included 
A. Guth, MS Thesis, 2007

alterations to cell size, color and morphology, among other cell characteristics, and made some species easily mistakable with others. This could provide additional difficulty for identifying microfossils in the cherts and sediments around Magadi, as lake level, salinity and $\mathrm{pH}$ have fluctuated throughout the history of the lake (Barker et al., 1990; Icole et al, 1990; Roberts et al., 1993; Trauth et al., 2005; Williamson et al., 1993). Jones and Grant (1999) discuss some of the different bacterial species and their roles in the carbon, sulfur and nitrogen cycles. They note that there is a distinctive difference in the microbial communities between Magadi and more dilute lakes like Nakuru to the north. Behr and Röhricht (2000) identified a number of coccoid cyanobacteria preserved in the Green Bed cherts; Pleurocapsa, Gloecocapsa polydermatica, Entophysalis granulose and Synechococcus, which are all mat-forming organisms, and Chroococcus minor. Also found were the mat-forming Microcoleus (a filamentous cyanobacteria), Phormidium and Schizothrix. These mat organisms were the most abundant seen in the samples; however, Micrococcus and Micromonospora bacteria and Hyphomicrobium were also identified. Diatoms were rare (only one genus, Navicula, was recognized) and a number of coccoid and rod-shaped cells were seen but could not be identified. Behr (2002) continues the discussion of the biologic remains found in the chert, and, in addition to the microorganisms mentioned in his previous paper, Microcystis, a free-floating unicellular genus, is also identified.

In addition to the study of the lake's microbial communities, there have also been a number of biologic studies on the tilapia fish that live in the extreme Magadi environment. Gikunju et al. (1992) examined the fluoride concentrations in the tilapia. Franklin et al. (1994) investigated the oxygen consumption of Tilapia from Magadi, and 
A. Guth, MS Thesis, 2007

found tilapia living in pools over $42^{\circ} \mathrm{C}$. It was noted that oxygen consumption by the fish increased at higher temperatures and a gulping behavior observed indicated that the fish use aerial respiration to supplement their $\mathrm{O}_{2}$ needs. Wilson et al. (2000) found that the tilapia in Magadi are separated into three habitats that are divided by the trona deposits, with genetic studies showing an extended period of separation between the Fish Springs and Southeast Lagoon populations. Wilson et al. (2000) also found that Fish Springs tilapia have an airbladder to do supplementary respiration, they excrete urea instead of ammonia due to the high $\mathrm{pH}$ of the water, and these fish also have the highest recorded routine metabolic rate for a cold-blooded bony fish. Anatomical differences between the gills of the Fish Springs and Southeast populations were also observed. At the time of this thesis however, the third tilapia population in the Southwest lagoon had not been studied. Walsh et al. (2001) conducted a study focused on the urea production of Magadi tilapia and found that their urea excretion rates were similar to that of mammals. Most fish can get rid of ammonia directly, but a high $\mathrm{pH}$ environment like Magadi would prevent the direct expulsion of ammonia. Urea is normally produced by mammals as a way of getting rid of ammonia, as it is a much less toxic waste product. The Magadi tilapia have adapted to this harsh environment by producing urea instead of ammonia, and the fish collected for this study continuously excreted urea (rather than in discrete pulses), with most of the nitrogen exchange occurring by the gills.

A 2004 paper by Wilson et al. goes into further depth with the genetic analysis of the Lake Magadi tilapia, provides a good overview of earlier studies, and also presents a brief analysis of the spring waters as seen above in the discussion about the Lagoon waters. It should be noted however, that the spring names used in Wilson's paper differ 
A. Guth, MS Thesis, 2007

from the names commonly used in the geologic reports. Correlations between the lagoon names used in Wilson's paper and those seen in the geologic reports can be seen in the Table 4 notes above.

Seven biologic samples were collected during the 2006 field season in order to generally categorize the growths around the hotsprings. During the 2005 field season, it was noted that there were several distinctive types of growth (different shades of green, swaths of magenta etc.) surrounding the hotsprings. The original intent was to pick one hotspring and map the changes in fauna away from the vent as temperature and water depth changed. However, the distinct changes of color seen in 2005 were not observed in 2006, and it was decided that the relative positions of the mats probably shift throughout the year. Notably, the vibrant red/magenta colored mats seen in 2005 seemed to be mostly gone, or covered by green growth during the 2006 field visit. When the hotsprings were visited in 2005, it was wet enough that it was nearly impossible to drive across the mudflat to get to the springs, but by the time the springs were visited in 2006, it was dry enough to drive. It is possible that as the area dries out the populations shift or change in dominance.

Instead of the intended sampling plan, samples were taken of the different representative growths seen around the hotsprings in an attempt to generally categorize the organisms that live there. A water sample was taken at each collection site in addition to the biologic sample. Water temperature at each site was measured, and $\mathrm{pH}, \mathrm{Na}+$ and $\mathrm{K}+$ were measured for all but 1 sample within 6 hours of collection. The biologic samples were preserved with a $2 \%$ solution of formaldehyde formed by mixing formalin with the requisite amount of spring water at the sample collection site. While glutaraldehyde 
A. Guth, MS Thesis, 2007

would have been the preferred preservative, with the difficulty of international travel with chemicals, it was determined that obtaining formalin in Nairobi would be most efficient.

Samples were examined under wet mount with a Zeiss Axioplan2 microscope and digital micrographs were acquired using a MTI 3CCD camera with Scion ImagePC software (release Beta1a for Windows95). The digital files were calibrated by taking images of a calibrated slide at different magnifications and determining the number of pixels between the scale bars. Because the camera is at a fixed distance (assuming that stage height is not altered between images of the same magnification), it was determined that the length represented by a pixel should not change at a given magnification setting. It was also determined that the length represented by a pixel should change linearly with the change in magnification. To test both of these assumptions, up to three images of the calibrated slide were taken at a given magnification with refocusing between each, and the number of pixels between the scale bars were measured and compared. Pixel counting was done with the "Calliper Rule" in the GraphicConverter image program to eliminate human error in manually counting pixels. Image taken by the camera attached to the microscope system are rotated with respect to the view through the microscope, so care was taken that the pixel measurements were taken perpendicularly to the imaged scale bars. Measurements were repeated multiple times per image to test precision. Once a measurement was obtained for the 100x image, predicted pixel calibrations were made assuming a linear relationship between pixel size and magnification to compare with the measured results.

It can be seen in Table 5 below that the predicted number of pixels per scaled distance changed linearly as expected, and since measurements were stable between 
A. Guth, MS Thesis, 2007

images taken at separate times, it seems justifiable to use this method for calibrating the digital images.

Table 5: Pixel calibration measurements for digital microscope images taken with a MTI 3CCD camera on a Zeiss Axioplan2 microscope.

\begin{tabular}{|l|l|c|c|c|}
\hline Magnification & $\begin{array}{l}\text { \# of } \\
\text { measurements }\end{array}$ & $\begin{array}{l}\text { Rounded Average \# } \\
\text { pixels/ 0.01mm }\end{array}$ & $\begin{array}{l}\text { Predicted \# } \\
\text { pixels/0.01 mm }\end{array}$ & $\begin{array}{l}\text { Error between } \\
\text { predicted and } \\
\text { measured (! m) }\end{array}$ \\
\hline $100 \mathrm{x}$ & 6 & 9 & - & - \\
\hline $160 \mathrm{x}$ & 6 & 14 & 14.4 & 0.29 \\
\hline $400 \mathrm{x}$ & 6 & 35 & 36 & 0.29 \\
\hline $640 \mathrm{x}$ & 6 & 56 & 57.6 & 0.29 \\
\hline $1000 \mathrm{x}$ & 3 & 87 & 90 & 0.34 \\
\hline $1600 \mathrm{x}$ & 3 & 141 & 144 & 0.21 \\
\hline
\end{tabular}

Scale bars were added to the digital images of the biologic samples in GraphicConverter, again using the caliper rule tool to ensure that the added bars were the correct number of pixels long.

\section{Characterization of Lake Magadi Biology}

Samples were identified by visual comparison, with the goal to achieve identification of at least genus-level. Results are shown in Table 6 and images of the collected samples and their proposed identifications can be found in Appendix A (Figures $27-33)$.

The hypothesis that the biologic growths around the hotspring could be characterized and identified based on visible properties such as color, texture and habit, seems to be validated by the results. All the samples represented distinctive forms seen in the springs, and indeed, each sample seems to be dominated by a different organism (rather than seeing the same organism forming two very different growths or samples being well mixed biologically). When attempting to identify the samples, organisms 
A. Guth, MS Thesis, 2007

represented in Appendix $\mathrm{H}$ were given preference as they are already known to occur in Lake Magadi. However, given the number of papers in recent years detailing the discovery/isolation of new bacteria from the lake (Florenzano et al.., 1985; Zhilina et al. 1996; Kevbrin et al., 1998; Grant et al., 1999; Zhilina, et al.,1998; Zhilina, et al., 2001a; Zhilina et al., 2001b; Boltyanskaya et al., 2004; Bhatnagar and Bhatnagar, 2005), it seems very plausible that certain genera or species may have been overlooked or discounted during the identification process if they had not been mentioned in the available literature.

In addition to the water parameters given in Table 6 below, a few dissolved oxygen (DO) measurements were taken during the 2005 field season. While the DO measurements cannot be correlated directly to the exact locations where the 2006 samples were collected, it still may be instructive to discuss them. The measurements were taken in the field from the same general springs as where samples A1-A5 were collected. Measurements were made with an Extech Instruments Heavy Duty Dissolved Oxygen Meter, model 407510. Measurements ranged from 0.5 to $0.9 \mathrm{mg} / \mathrm{L} \mathrm{DO}$, however, the stated accuracy of the oxygen meter is $+/-0.4 \mathrm{mg} / \mathrm{L}$, so it cannot be stated if there really is a difference in DO between the springs in this area. These measurements have not been corrected for elevation or salt content, however, temperature is the main determining factor for how much oxygen can be held in solution. This range of DO represents between $10-18 \%$ saturation based on an elevation of $600 \mathrm{~m}$, temperature of $45-48^{\circ} \mathrm{C}$ and 8 ppt of salts (obtained from the average sum of total $\mathrm{Na}+$ and $\mathrm{K}+$ as measured for biologic samples A1-A5). These waters are oxygen poor, which may, in addition to the high temperatures, explain the lack of tilapia near the hotspring vents. While no quantitative 
A. Guth, MS Thesis, 2007

measurements were taken, the DO meter gave a spike in readings when the probe tip brushed against gas bubbles trapped by some of the bacterial mats in the springs. As the microbes collected were identified, for the most part, as photosynthetic cyanobacteria, it is expected that oxygen would be produced during the day and possibly trapped in the microbial mats.

Table 6: Basic water conditions for the different cyanobacteria samples in addition to infield sample description and proposed identification. Refer to Figures 27-33 for images of each of the samples and their proposed identifications.

\begin{tabular}{|l|l|l|l|l|l|l|}
\hline ID \# & $\begin{array}{l}\text { Water } \\
\text { Temp }{ }^{\circ} \mathrm{C}\end{array}$ & $\mathrm{pH}$ & $\begin{array}{l}\mathrm{Na}+ \\
\mathrm{ppm}\end{array}$ & $\begin{array}{l}\mathrm{K}+ \\
\mathrm{ppm}\end{array}$ & Sample Description & $\begin{array}{l}\text { Proposed } \\
\text { Identification }\end{array}$ \\
\hline A1 & 41.5 & 10.2 & 7900 & 98 & $\begin{array}{l}\text { Grew along low linear ridges } \\
\text { in standing water. Green- } \\
\text { brown in color. }\end{array}$ & Oscillatoria \\
\hline A2 & 42.8 & 10.2 & 7500 & 86 & $\begin{array}{l}\text { Yellow-green, floating on the } \\
\text { surface near the springs. } \\
\text { Trapped large bubbles in a } \\
\text { slimy film. }\end{array}$ & Synechocystis \\
\hline A3 & 41.8 & 10.3 & 7500 & 86 & $\begin{array}{l}\text { Red mat, right at the mouth of } \\
\text { a small seep. Almost } \\
\text { completely covered by a dark } \\
\text { green growth. }\end{array}$ & Calothrix* \\
\hline A4 & 43.4 & 10.3 & 7500 & 82 & $\begin{array}{l}\text { Purple in color, encrusting a } \\
\text { small rock, mostly covered by } \\
\text { green growth. }\end{array}$ & $\begin{array}{l}\text { Synechococcus } \\
\text { and Spirulina } \\
\text { subsalsa }\end{array}$ \\
\hline A5 & 44.4 & 10.2 & 7900 & 90 & $\begin{array}{l}\text { Dark green gritty pillars right } \\
\text { near hot spring. Only growth } \\
\text { in area and was spotted in } \\
\text { other bare locations near } \\
\text { hotsprings with a fine gravel } \\
\text { substrate. }\end{array}$ & $\begin{array}{l}\text { Chromatiacaea } \\
\text { vinosum and } \\
\text { Phormidium }\end{array}$ \\
\hline A6 & 34.6 & 10.4 & 8250 & 100 & $\begin{array}{l}\text { Red-brown mat-forming } \\
\text { variety found near very weak } \\
\text { springs. Did not seem to have } \\
\text { any competition. }\end{array}$ & $\begin{array}{l}\text { Myxosarcina } \\
\text { NA }\end{array}$ \\
\hline
\end{tabular}

*Note, while these identifications seem to be a good match with what was imaged under the microscope, it is possible that intended sample was not obtained. For example, what was thought to be a sample of a red mat-forming organism was identified as Calothrix, which is a cyanobacterial, and the actual red, mat-forming organism may not have been identified. 
A. Guth, MS Thesis, 2007

One interesting observation is that Sample A6 started in the field as a dark $\mathrm{red} / \mathrm{brown}$ color, but after collection, preservation, and storage at room temperature for a few months, the sample had altered to green in color with translucent edges. While the exact cause of the color change is unknown, it may be possible that accessory light harvesting pigments might have degraded. Identifying sample A6 also proved troublesome as none of the microbes mentioned in the literature matched the characteristics of this mat-forming organism seen commonly around the shore of the lagoons. The ovoid cells in Sample A5 were difficult to identify as there were several unrelated genera that looked similar. A7 was collected from a fresher pool located near the salt ponds and appears to be composed of Spirulina, which is an important food source for the flamingoes in the area (Ndetei and Muhandiki, 2005; Koenig, 2006). While water testing was not performed on the A7 sample during the same time frame as Samples A1-A6, it seems logical that the sampled water was fresher and cooler than the samples taken directly from the springs sampled for A1-A6. This is based on the abundance of birds in the A7 pool, the relative deep nature of the pool (the springs sampled for A1-A6 were quite shallow, where as at A7 the bottom could not be seen), in addition to the larger size of the tilapia at this location. Maina et al., (1996) studied tilapia found in Lake Magadi, and found that even though the fish in Fish Springs Lagoon (where sample A7 was collected) were genetically the same as fish found in a water holding tank (the fish would travel through the water intake pipes), the fish in the holding tank were over twice as large due in part to cooler water temperatures making for a less harsh environment.

Copyright (C) Alexandria L. Guth 
A. Guth, MS Thesis, 2007

Of the identified samples, Synechococcus and Phormidium (a.k.a., Schizothrix) were noted by Behr and Röhricht (2000) to be present in the 98,000 year old Magadi cherts. These two organisms are still living at the modern springs and are also part of the geologic history of the area. Additionally, Synechococcus was described as being a major precipitator of carbonates by Thompson and Ferris (1990) in addition to having the ability to alkalinize their surroundings through photosynthetic metabolism. This increase in alkalinity occurs due to the use of $\mathrm{HCO}_{3}{ }^{-}$by Synechococcus as a primary carbon source. Also, due to the increase in $\mathrm{pH}$, Magnesite $\left(\mathrm{MgCO}_{3}\right)$ was also noted by Thompson and Ferris (1990) to be associated with dense colonies of Synechococcus in experiments. During a period of 72 hours, these cyanobacteria were observed to increase the $\mathrm{pH}$ of their surroundings from 7.97 to 8.57 . A variety of other interactions can occur between biological agents and their environment, however, it is not within the scope of this research to list all the potentials. Of particular interest, Janusz (2004) showed that bacteria (specifically Natrialba magadii, from Lake Magadi) can influence the morphology of zeolites as they use the minerals for cations and water exchange during dry periods and Heinen and Oehler (1979) discuss the roles microbes can play in general, in the silica-cycle. Not only do microorganisms get preserved in the geologic record, they also alter their environment and can help deposit minerals. While the exact role of these biologic communities with respect to the geologic history of the Magadi basin is unknown, they probably did affect the stability and deposition of certain minerals through time. 
A. Guth, MS Thesis, 2007

\section{Conclusions}

While many topics were covered during the course of this study, there were three main products derived from this research:

1. A geologic model detailing the evolution of the Southern Kenya Rift produced through utilization of actual field work performed by previous authors/researchers which was then synthesized to form a more complete picture of events in this area.

2. Demonstration that combining vintage geologic maps with satellite imagery is a successful tactic to produce updated geologic maps that are more detailed and versatile that the originals.

3. A reworking of the volcanic and sedimentary stratigraphy using numerous age dates to produce a cohesive account of the volcanism and sedimentation in this area over the past 15 million years.

\section{Evolution of the Southern Kenya Rift:}

One of the continuing questions concerning rift valleys is the nature and timing of their evolution and formation; when and how do they form? A key step in understanding this is to look at the timing of rift-related volcanism in a spatial context. While this work does not cover the entire East African Rift, nor even the entire Kenya Rift, it does however take beginning steps in that direction by showing that the lower third of the Kenya Rift experienced three discrete periods of volcanism over the past 15 million years. The first eruptive phase occurred pre-rifting with the oldest units in the area being 
A. Guth, MS Thesis, 2007

the 15Ma melanephelinites of the Kishalduga and Lisudwa formations. These two formations however, were of fairly limited extent, and of the volcanism during this first eruptive phase prior to $10 \mathrm{Ma}$, the Plateau Phonolites that were erupted over much of the Kenya Dome between 13-10Ma dominated volumetrically. Following this initial activity, the area was volcanically quiet until, what could be considered the second phase, took place after the initial rift faulting. This initial faulting only defined the western boundary of the rift and occurred around 7Ma. The oldest of the second phase volcanics were the Lengitoto trachytes which were erupted into the early half rift graben. Since this flow was confined by the escarpment on one side, and probably also erupted from fissures of similar orientation, this formation exhibits an elongated morphology based on present outcrop area. This is in contrast to the earlier flows that were probably erupted onto flat or gently sloping terrains, and seemed to form lobate shapes as demonstrated by the Nairobi Phonolites.

The third phase occurred after the formation of a complete rift graben when the eastern side finally faulted some 3 million years after the initial movements that defined the western boundary. It is tentatively speculated that the reason for the extended period between the events that defined the west and eastern boundaries of the rift may be related to the difference in crustal thickness on the different sides, with the eastern side having the thicker crust. During the most recent $3.5 \mathrm{Ma}$, the amount of rift-related volcanism volumetrically surpassed that of the earlier Plateau Phonolites. However, the Plateau Phonolites are thought to have erupted most of their bulk in less than 1 million years (Fitch et al., 1978) whereas the recent volcanism was erupted in relatively small, discrete eruptions. Volcanic activity in the study area has been quiet since around 600 thousand 
A. Guth, MS Thesis, 2007

years ago, except for the building of Suswa to in the north which started around 240 thousand years ago. Since then most of the geologic activity has been related to the expansion and contraction of lake levels in the rift and the deposition of sedimentary formations.

\section{Digital mapping}

This study also showed that vintage geologic reports and maps can be combined with modern satellite images to create digital maps that are often more detailed and accurate than the original maps. Quadrangle maps can be improved by using 15 meter Landsat images as base-maps, which are easily available, free, and allow mapping of detail on a level similar to, or better, than the original 1:125,000 scale maps. Additional improvements can be made when more recently published articles, with smaller-scale or sketch maps that make updates to geological boundaries, are assimilated into the mapping process. There are also benefits inherent to digital data such as the ability to easily manipulate boundaries, use the same digital files for multiple purposes (such as showing time sequences or adjusting formation colors, layers or labeling to create maps for varied uses) and to easily share/distribute data and produced maps.

Time series maps were made possible through the collection of over 300 published age dates covering the entire Kenya Rift. A concerted effort to gather age dates for this part of the rift has not been made since 1971 when Baker et al. published "Sequence and geochronology of the Kenya rift volcanoes". Many new, and better defined, age dates have been published since then, and they lead to an enhanced view of the timing of rift volcanism and sedimentation. Also important to the mapping process 
A. Guth, MS Thesis, 2007

was the correlation of geologic units across map boundaries as many units have been added, renamed and/or subdivided since the original maps were produced.

An extensive library of age dates, in addition to the digital map data that spans old map boundaries seamlessly, can lead to a number of interesting applications. Examining volume of erupted volcanic material or fault displacements versus time are two such applications that can provide an instructive look into the evolution of the rift. Such exercises would be even more useful when combined with data covering larger stretches of the EARS.

These techniques are probably widely applicable to other areas and were made successful in the Southern Kenya Rift due to the extensive library of previous works that could be drawn upon, relatively young formations that enhanced the definition between formations, and the sparse vegetation and dry seasons that allowed for clear satellite views. The wide application of these methods is enhanced by the free satellite data available online. While the resolution is not fine enough to map small areas in detail, it is quite sufficient for mapping quarter degree areas. For areas lacking the substantial number of previous works like those available for the Kenya Rift, it may be possible to make a tentative map using similar techniques prior to starting field work.

\section{Stratigraphy}

In order to combine the various geologic maps that covered the study area into a single, cohesive, map, a correlation table had to be made. Unit names and boarders did not always line up so decisions had to be made as to what map had the borders and unit designations preferred for mapping. In general, the newest maps (those found in journal articles) were preferred and used to update the older Kenya Geologic Survey (KGS) maps 
A. Guth, MS Thesis, 2007

(it should be kept in mind that while the publishing dates for some of the KGS reports are listed as 1991, the actual maps were created decades earlier and do not reflect updates made by publications from the 1970's-1980's). The compiled age dates, many of which were produced after the initial mapping efforts, were combined with the correlation table to construct a comprehensive stratigraphy for the entire study area. Formation symbology, for use in map construction, has been totally reworked for the mapping project to account for the better constrained formation ages, better knowledge of the stratigraphy/geologic history, and the fact that the newly produced map represents an area previously covered by 6 quarter degree maps.

The stratigraphy of the Magadi area has been changed a number of times since Baker's Kenya Geologic Survey report on the area (1958). Most of the uncertainty has been associated with the sediments that have patchy preservation and limited aerial extent. Additionally, a lot of early work done to define the sequence of formations was completed prior to the collection of age dates from sediments of the rift valley. The preferred sedimentary stratigraphy for the Magadi area is that presented in Behr and Rohricht (2000), which also demonstrates that the original sedimentary order presented by Baker (1958) over 40 years earlier was on target, with the minor change of the renaming of the Chert Series to the Green Beds.

Age dates are clearly a valuable tool in straightening out the geochronology of this area, which otherwise can be hopelessly complicated. It was for this reason that age dates covering the entire Kenya Rift were compiled. While many of the formations do not appear in the study area covered by this thesis, starting a compilation may help continue similar studies up the Kenya Rift. 
A. Guth, MS Thesis, 2007

\section{Biology}

There is obviously a complex and dynamic microbial population at the springs of Lake Magadi. This study has demonstrated that the microbiology of the hotsprings at Magadi can be distinguished in the field by visual clues such as growth shape, texture, color and location. Only seven biologic samples were analyzed for this study, but each sample was unique both macro- and microscopically. One commonality was that the bulk of all samples were identified as cyanobacteria. The only actual algae seen during this investigation were a few scattered diatoms that were not important constituents of the growths sampled. With new bacteria being isolated from Lake Magadi on a fairly regular basis, it is safe to say that there is a lot more to discover about the microbiology of the lake, especially with regards to bio-geologic interactions. The analysis provided here regarding the biology of the Lake Magadi hotsprings is in no way exhaustive, but could provide a useful springboard for future research regarding the unique microbial populations of this lake.

\section{Future Work}

Lake Magadi and its surrounding area still present a number of opportunities for future work. While Magadi has been a shot point for the large scale KRISP studies, there has yet to be a detailed seismic study of the lake basin and surrounding area. Having a detailed view of the bottom of the Magadi trough would allow for a more complete analysis of core data from the lake. It would also be instructive to perform seismic studies near the chert dykes in the South East Lagoon at Magadi. If there really are chert 
A. Guth, MS Thesis, 2007

dykes/diapirs as Behr and Röhricht (2000) believe, then that should be easily visualized using seismic techniques, which could, in addition, possibly identify their source horizon.

There are also opportunities for isotopic studies in the area. Alleman et al. (2005) examined the silicon isotope fractionation in Lake Tanganyika, which is in the western branch of the EARS. They found that biologic activity preferentially uses ${ }^{28} \mathrm{Si}$ and thus enriches the surrounding waters in ${ }^{29} \mathrm{Si}$ and ${ }^{30} \mathrm{Si}$. It would be interesting to examine the cherts around Lake Magadi, especially to compare the magadiite with the Green Bed cherts, to see if there is any isotopic evidence to support the idea of biologic mediation for the Green Beds and/or inorganic formation of the magadiite and associated cherts.

Also of interest is some of the work regarding desert varnish dating. One study (Harrington and Whitney, 1987) suggests that by comparing the average thicknesses of the varnish an age can be estimated. In the Magadi area, the Green Bed cherts that are prominently exposed as dikes seem to have a dark varnish or coating on them, and it may be instructive to see if they give consistent thickness/ages across the outcrops. If consistent varnish thicknesses are obtained, it may be possible to estimate when the chert was exposed or when the siliceous material hardened, which could give further insight into the formation of this unit. In addition to the possible desert varnish studies, Brueckner (1979) mentioned that it may be possible to date cherts using Rb-Sr isotopes. While it seems fairly secure at this point that there are several generations of chert at Magadi, it could be useful to try dating the chert directly. There are also other opportunities for age dating which would be beneficial in filling gaps in the current knowledge. There are a number of formations whose ages are only constrained by one age date which may have been performed several decades ago. 
A. Guth, MS Thesis, 2007

Continued mapping along with plotting volume and faulting versus time for larger sections of the rift could lead to analysis or recognition of patterns in rift development. For example, it is reported in Keranen et al. (2004) that the Ethiopian Rift also experienced a hiatus in volcanism of about $3 \mathrm{Ma}$ and it would be interesting to see if this hiatus corresponds with breaks in volcanism in the Kenya Rift.

Crane (1981) mentions that the hot springs at Lake Magadi are large enough to monitor by satellite, and thus it might be possible to monitor changes in heat flow over time and through the southern Kenya Rift. If it was considered possible in 1981, advances in the spatial resolution of thermal imaging satellites in the time since then would be an added benefit of attempting such a study.

Additionally, there exists core data for a large number of exploratory holes drilled by the Magadi Soda Company, in addition to cores drilled and examined by a number of authors over the past 50 years (Baker 1958, Surdam and Eugster 1976, Barker et al., 1990; Damnati et al., 1992; Roberts et al., 1993; Williamson et al., 1993; Damnati and Taieb, 1995). These core data could be combined to provide detailed sediment mapping across the Lake Magadi basin for a detailed treatment of environment change and basin dynamics.

Obviously the microorganisms at Magadi could receive a more thorough treatment, especially in terms of seasonal growth cycles and roles in the formation of geologic units. Identification attempts could also be improved by using more advanced imaging techniques to better highlight cell structures in addition to molecular studies of the populations present at the Magadi springs.

Copyright (C) Alexandria L. Guth 
A. Guth, MS Thesis, 2007

\section{Reference Library}

\section{Online Resources:}

Burnette, Ryan. "Purple Sulfur Bacteria” Virginia Tech. Retrieved April 18, 2007. <http://filebox.vt.edu/users/chagedor/biol_4684/Microbes/purprnb.html>

"Digital Chart of the World " Retrieved April 18, 2007, Penn State University Libraries <http://www.maproom.psu.edu/dcw/>

"GeoCover Landsat" Lamar Nicholson. NASA. Retrieved April 19, 2007 $<$ https://zulu.ssc.nasa.gov/mrsid/>

"GEOROC: Geochemistry of Rocks of the Oceans and Continents" Barbel Sabas. March 01, 2007. Max-Planck-Institut für Chemie. Retrieved April 18, 2007 <http://georoc.mpch-mainz.gwdg.de/georoc/>

"Global Volcanism Program" 2002-, Smithsonian Institution. Retrieved April 25, 2007 $<$ http://www.volcano.si.edu/>

"Information Bulletin Kenya: Drought." December 24, 2005. Kenya Red Cross. Retrieved April 18, 2007 <http://www.kenyaredcross.org/>.

International Commission on Stratigraphy. Site produced by Prof. Sorin Filipescu, August 2007. Retrieved August 2, 2007 < http://www.stratigraphy.org/>.

"Institute of Vegetal Biochemistry and Photosynthesis" January 20, 2007. CSIC Universidad de Sevilla. Retrieved April 18, 2007, < http://www.ibvf.csic.es/Cultivos/Seccion_I.htm>

Komárek, Jiří and Hauer, Tomáš "CyanoDB - The on-line database of cyanobacterial genera." March 07, 2007. University of South Bohemia and Academy of Sciences of the Czech Republic. Retrieved April 19, $2007<\mathrm{http}: / / w w w . c y a n o d b . c z />$

"Magadi Soda". Retrieved April 22, 2007. < http://www.magadisoda.co.ke/>

"Microbial Culture Collection" February 14, 2007. National Institute for Environmental Studies. Retrieved April 19, 2007 < http://www.nies.go.jp/biology/mcc/home.htm>

"Správce Galerie". August 01, 2006. University of South Bohemia. Retrieved April 19, 2007. $<$ http://galerie.sinicearasy.cz/main.php>

"UTEX Culture Collection of Algae" October 27, 2006. University of Texas Austin. Retrieved April 18, 2007, < http://www.zo.utexas.edu/research/utex/photogallery/Images/>

\section{Works cited}

Alleman, L. Y., D. Cardinal, et al. (2005). "Silicon isotopic fractionation in Lake Tanganyika and its main tributaries." Journal of Great Lakes research 31(4): 509 (11 pages).

Atmaoui, N. and D. Hollnack (2003). "Neotectonics and extension direction of the southern Kenya Rift, Lake Magadi area." Tectonophysics 364(1-2): 71-83.

Bailey, D. K., R. Macdonald, et al., Eds. (1987). Dry peralkaline felsic liquids and carbon dioxide flux through the Kenya Rift zone, Geochemical Society, University Park, PA. 
Baker, B. H. (1958). Geology of the Magadi area; degree sheet 51, S. W. quarter. Nairobi, Republic of Kenya, Mines and Geological Department: 81.

Baker, B. H. (1963). Geology of the Area South of Magadi; degree sheet 58, N.W. quarter, Republic of Kenya, Mines and Geological Department: 27.

Baker, B. H. (1965). An outline of the geology of the Kenya rift valley. Report on the geology and geophysics of the east African rift system, Kenya: 1-19.

Baker, B. H. (1975). "Geology and geochemistry of the Ol Doinyo Nyokie trachyte ignimbrite vent complex, South Kenya Rift valley." Bulletin Volcanologique 39(3): 420-440.

Baker, B. H., R. Crossley, et al. (1977). Tectonic and magmatic evolution of the southern part of the Kenya Rift valley. Petrology and Geochemistry of Continental Rifts. E. R. Neumann and I. B. Ramberg, D. Reidel Publishing Company, Dordrecht-Boston, International: 2950.

Baker, B. H., G. G. Goles, et al. (1977b). "Geochemistry and petrogenesis of a basaltbenmoreite-trachyte suite from the southern part of the Gregory Rift, Kenya." Contributions to Mineralogy and Petrology 64(3): 303-332.

Baker, B. H. and J. G. Mitchell (1976). "Volcanic stratigraphy and geochronology of the Kedong-Olorgesailie area and the evolution of the South Kenya rift valley." Journal of the Geological Society of London 132: 467-484.

Baker, B. H., J. G. Mitchell, et al. (1988). "Stratigraphy, geochronology and volcano-tectonic evolution of the Kedong-Naivasha-Kinangop region, Gregory Rift valley, Kenya." Journal of the Geological Society of London 145(1): 107-116.

Baker, B. H., P. A. Mohr, et al. (1972). "Geology of the Eastern Rift System of Africa." Special Paper - Geological Society of America 136.

Baker, B. H., L. A. J. Williams, et al. (1971). "Sequence and geochronology of the Kenya rift volcanoes." Tectonophysics 11(3): 191-215.

Barker, P., F. Gasse, et al. (1990). "Taphonomy and diagenesis in diatom assemblages; a Late Pleistocene palaeoecological study from Lake Magadi, Kenya." Hydrobiologia 214: 267272.

Barthelme, J., S. Murimi, et al. (2003). "Recent Archaeological Research in the Lake Magadi Basin, Southern Kenya." Nyame Akuma, BULLETIN OF THE SOCIETY OF AFRICANIST ARCHAEOLOGISTS(No. 60): 8-13.

Baumgarte, S. (2003). Microbial diversity of soda lake habitats. Biology. Braunschweig, Germany, Techn. Univ Carolo-Wilhelmina: V, 187 S.

Behr, H.-J., (2002). Magadiite and Magadi chert; a critical analysis of the silica sediments in the Lake Magadi Basin, Kenya. Sedimentation in Continental Rifts. R. W. Renaut and G. M. Ashley, Society for Sedimentary Geology (SEPM), Tulsa, OK. Special Publication 73: 257-273.

Behr, H.-J. and C. Roehricht (2000). "Record of seismotectonic events in siliceous cyanobacterial sediments (Magadi cherts), Lake Magadi, Kenya." International Journal of Earth Sciences 89(2): 268-283.

Behrensmeyer, A. K., A. L. Deino, et al. (2002a). "Geology and geochronology of the middle Miocene Kipsaramon site complex, Muruyur Beds, Tugen Hills, Kenya." Journal of human evolution 42 Part 1/2: 11-38.

Behrensmeyer, A. K., R. Potts, et al., Eds. (2002b). Olorgesailie, Kenya; a million years in the life of a rift basin, Society for Sedimentary Geology (SEPM), Tulsa, OK. 
Bellieni, G., P. Brotzu, et al. (1986). "Petrology and mineralogy of Miocene fissural volcanism of the East Kenya Plateau." Neues Jahrbuch fuer Mineralogie. Abhandlungen 154(2): 153-178.

Bhatnagar, A. and M. Bhatnagar (2005). "Microbial diversity in desert ecosystems " Current Science 89(1): 91-100.

Boltyanskaya, Y. V., A. N. Antipov, et al. (2004). "Halomonas campisalis, an Obligatorily Alkaliphilic, Nitrous Oxide-Reducing Denitrifier with a Molybdenum Cofactor-Lacking Nitrate Reductase." Microbiology 73(3): 271-278.

Brueckner, H. K. and W. S. Snyder (1979). "Rb-Sr dating of chert; a potential chronological tool." Abstracts with Programs - Geological Society of America 11(3): 71.

Burke, K. C. and J. T. Wilson (1976). "Hot spots on the Earth's surface." Scientific American 235(2): 46-57.

Butzer, K. W., G. L. Isaac, et al. (1972). "Radiocarbon Dating of East African Lake Levels." Science 175(4026): 1069-1076.

Bye, B. A., F. H. Brown, et al. (1987). "Increased age estimate for the lower Palaeolithic hominid site at Olorgesailie, Kenya." Nature (London) 329(6136): 237-239.

Chapman, G. R., and M. Brook. (1978) Chronostratigraphy of the Baringo Basin, Kenya. Geological Background to Fossil Man. W. W. Bishop, Scott. Acad. Press, Edinburgh, United Kingdom: 207-223.

Charsley, T. J. (1987). Geology of the Laisamis area : degree sheet 28 with coloured 1:250 000 geological map and results of geochemical exploration. Nairobi, Ministry of Environment and Natural Resources, Mines and Geology Dept.

Chorowicz, J., O. Catuneanu, et al., Eds. (2005). The East African Rift system, Pergamon, Oxford, United Kingdom.

Crane, K. (1981). "Thermal variations in the Gregory Rift of southern Kenya(?)." Tectonophysics 74(3-4): 239-262.

Crossley, R. (1979). "The Cenozoic stratigraphy and structure of the western part of the Rift Valley in southern Kenya." Journal of the Geological Society of London 136: 393-405.

Crossley, R. (1980). Structure and volcanism in the S Kenya Rift. Atti dei Convegni Lincei, Accademia Nazionale dei Lincei 47: 89-98.

Crossley, R. and R. M. Knight (1981). "Volcanism in the western part of the Rift Valley in southern Kenya." Bulletin Volcanologique 44(2): 117-128.

Darracott, B. W., J. D. Fairhead, et al. (1972). "Gravity and magnetic surveys in northern Tanzania and southern Kenya." East African Rifts Tectonophysics 15(1-2): 131-141.

Davies, G. (1998). "A channelled plume under Africa." Nature (London) 395(6704): 743-744.

Dawson, J. B., H. Pinkerton, et al. (1990). "Physicochemical properties of alkali carbonatite lavas; data from the 1988 eruption of Oldoinyo Lengai, Tanzania." Geology (Boulder) 18(3): 260-263.

Dominguez-Rodrigo, M., J. Serrallonga, et al. (2001). "The human evolution project at Peninj (Tanzania)." Retrieved Dec 11, 2006, from http://www.ucm.es/info/preh/actividades/peninj/home.htm.

Dubinin, A. V., L. M. Gerasimenlco, et al. (1995). "Ecophysiology and Species Diversity of Cyanobacteria from Lake Magadi." Microbiology 64(6): 717 (5 pages).

Ebinger, C. J. and N. H. Sleep (1998). "Cenozoic magmatism throughout East Africa resulting from impact of a single plume." Nature (London) 395(6704): 788-791. 
Ebinger, C. J., T. Yemane, et al. (2000). "Rift deflection, migration, and propagation; linkage of the Ethiopian and Eastern rifts, Africa." Geological Society of America Bulletin 112(2): 163-176.

Eugster, H. P. (1967a). "Hydrous sodium silicates from Lake Magadi, Kenya; precursors of bedded chert." Science 157(3793): 1177-1180.

Eugster, H. P. (1969). "Inorganic bedded cherts from the Magadi area, Kenya." Contributions to Mineralogy and Petrology 22(1): 1-31.

Eugster, H. P. (1970). "Chemistry and origin of the brines of Lake Magadi, Kenya." Fiftieth Anniversary Symposia, Mineralogy and Geochemistry of Non-Marine Evaporites Special Paper - Mineralogical Society of America 3: 213-235.

Eugster, H. P. (1980). "Lake Magadi, Kenya, and its precursors", $\underline{\text { Hypersaline Brines and }}$ Evaporitic Environments Ed. A. Nissenbaum Elsevier Sci. Publ. Co., Amsterdam, Netherlands: 195-232

Eugster, H. P. and B. F. Jones (1968). "Gels composed of sodium-aluminum silicate, Lake Magadi, Kenya." Science 161(3837): 160-163.

Fairhead, J. D. and R. W. Girdler (1972). "The seismicity of the east African rift system." East African Rifts Tectonophysics 15(1-2): 115-122.

Fairhead, J. D., J. G. Mitchell, et al. (1972). "New K/Ar Determinations on Rift Volcanics of S. Kenya and their Bearing on Age of Rift Faulting." Nature; Physical Science (London) 238(83): 66-69.

Fitch, F. J., P. J. Hooker, et al. (1978). Geochronological problems and radioisotopic dating in the Gregory rift valley. Geological background to fossil man; recent research in the Gregory rift valley, East Africa. Ed. W. W. Bishop, Scottish Acad. Press, Edinburgh, Scot., United Kingdom | Univ. Toronto Press: 441-461.

Florenzano, G., C. Sili, et al., (1985). "Cyanospira rippkae and Cyanospira capsulata (gen. nov. and spp. Nov.); new filamentous heterocystous cyanobacteria from Magadi lake (Kenya)" Archives of Microbiology 140(4): 301-306

Franklin, Johnston, et al. (1995). "Scaling of oxygen consumption of Lake Magadi tilapia, a fish living at $37 \mathrm{deg}$; C." Journal of Fish Biology 46, no 5: 829-834.

Gaciri, S.J. (1992). "Lineament map of Kenya; corrections of lineaments to known geological data." Tectonophysics vol. 209, no. 1-4: 139-142

George, R., N. Rogers and S. Kelley (1998). "Earliest magmatism in Ethiopia; evidence for two mantle plumes in one flood basalt province." Geology (Boulder) 26(10): 923-926.

Gerlach, T. M., (1989). "Degassing of carbon dioxide from basaltic magma at spreading centers; I, Afar transitional basalts", Eds. Le Guern, et al., Journal of Volcanology and Geothermal Research, vol.39, no.2-3: 211-219

Gikunju, J. K., T. E. Maitho, et al. (1992). "Fluoride levels in water and fish from Lake Magadi (Kenya)." Hydrobiologia 234(2): 123.

Gittins, J. and B. C. Jago (1998). "Differentiation of natrocarbonatite magma at Oldoinyo Lengai volcano, Tanzania." Mineralogical Magazine 62(6): 759-768.

Goetz, C. and C. Hillaire-Marcel (1992). "U-series disequilibria in early diagenetic minerals from Lake Magadi sediments, Kenya; dating potential." Geochimica et Cosmochimica Acta 56(3): 1331-1341.

Grant, S., D. G. William, et al. (1999). "Novel archaeal phylotypes from an East African alkaline saltern." Extremophiles 3(2): 139-145. 
Green, W. V., U. Achauer, et al. (1991). "A three-dimensional seismic image of the crust and upper mantle beneath the Kenya Rift." Nature (London) 354(6350): 199-203.

Harrington, C. D. and J. W. Whitney (1987). "Scanning Electron Microscope Method for RockVarnish Dating." Geology (Boulder) 15(10): 967-970.

Heinen, W. and J. H. Oehler (1979). "Evolutionary aspects of biological involvement in the cycling of silica", Biogeochemical Cycling of Mineral Forming Elements Eds. Trudinger P.A. and D.J. Swain, Elsevier Sci. Publ. Co., Amsterdam, Netherlands: 431-442

Hillaire-Marcel, C., O. Carro, et al. (1986). "(super 14) C and Th/U dating of Pleistocene and Holocene stromatolites from East African paleolakes." Quaternary Research (New York) 25(3): 312-329.

Hofmann, C., V. Courtillot, et al. (1997). "Timing of the Ethiopian flood basalt event and implications for plume birth and global change." Nature (London) 389(6653): 838-841.

Ibs-von Seht, M., S. Blumenstein, et al. (2001). "Seismicity, seismotectonics and crustal structure of the southern Kenya Rift-new data from the Lake Magadi area." Geophysical Journal International 146, no 2: 439-453.

Icole, M., J.-P. Masse, et al. (1990). "Pleistocene lacustrine stromatolites, composed of calcium carbonate, fluorite, and dolomite, from Lake Natron, Tanzania; depositional and diagenetic processes and their paleoenvironmental significance." Sedimentary Geology 69(1-2): 139-155.

Janusz, R. and S. Birnbaum (2004). "A laboratory-scale alkaline-lake model of microbe-zeolite interactions." Geological Society of America, 2004 annual meeting Abstracts with Programs - Geological Society of America 36(5): 360-361.

Jones, B. E., Grant W.D. (1999). Microbial diversity and ecology of the Soda Lakes of East Africa. International Symposium on Microbial Ecology. Halifax, Nova Scotia, Canada.

Jones, B. F., S. L. Rettig, et al. (1967). "Silica in alkaline brines." Science 158(3806): 13101314.

Joubert, P. (1957). Geology of the Namanga-Bissel area; explanation of degree sheet 58 N.E. and S.E. Nairobi, Kenya, Republic of Kenya, Mines and Geological Department: 49.

Keranen, K., S. L. Klemperer, et al. (2004). "Three-dimensional seismic imaging of a protoridge axis in the main Ethiopian Rift." Geology (Boulder) 32(11): 949-952.

Kevbrin, V. V., T. Zhilina, et al. (1998). "Tindallia Magadii Gen. Nov., Sp. Nov.: An Alkaliphilic Anaerobic Ammonifier from Soda Lake Deposits." Current microbiology 37(2): 94-100.

Key, R. M. (1987). Geology of the Marsabit area; degree sheet 20 with coloured 1:250,000 geological map and results of geochemical exploration. Nairobi, Republic of Kenya, Mines and Geological Department: 42.

Key, R. M. and R. T. Watkins (1988). Geology of the Sabarei area; degree sheets 3 and 4 with coloured 1:250,000 geological map and results of geochemical exploration. Nairobi, Republic of Kenya, Mines and Geological Department: 57.

Khan, M. A., J. Mechie, et al., (1999). "The lithospheric structure of the Kenya Rift as revealed by wide-angle seismic measurements." Continental Tectonics Geological Society of London, Special Publications 164: 257-269

King, B. C., (1970). Vulcanicity and rift tectonics in east Africa. African magmatism and tectonics. T. N. Clifford and I. G. Gass. Darien, Conn., Hafner Publ. Co.: 263-283.

Koenig, R. (2006). "The pink death: Die-offs of the lesser flamingo raise concern." Science 313(5794): 1724-1725. 
Lagat, J. (2003). Geology and the geothermal systems of the southern segment of the Kenya Rift. International Geothermal Conference, Reykjavík, United Nations University Geothermal Training Programme (UNU-GTP): 40-47.

Latin, D., M. J. Norry, et al. (1993). "Magmatism in the Gregory Rift, East Africa; evidence for melt generation by a plume." Journal of Petrology 34(5): 1007-1027.

Le Roex, A. P., A. Späth, et al. (2001). "Lithospheric thickness beneath the Southern Kenya Rift: Implications from basalt geochemistry." Contributions to Mineralogy and Petrology 142(1): 89-106.

Logatchev, N. A., V. V. Beloussov, et al. (1972). "East African rift development." East African Rifts Tectonophysics 15(1-2): 71-81.

Macdonald, R. (2003). "Magmatism of the Kenya Rift valley; a review." Transactions of the Royal Society of Edinburgh: Earth Sciences 93: 239-253.

Macdonald, R., N.W. Rogers, et al. (2001) "Plume-Lithosphere Interactions in the Generation of the Basalts of the Kenya Rift, East Africa." Journal of Petrology vol 42, no. 5: 877-900.

Maina, J. N., S. M. Kisia, et al. (1996). "A comparative allometric study of the morphometry of the gills of an alkalinity adapted cichlid fish, \{ bit Oreochromis alcalicus grahami, of Lake Magadi, Kenya." International Journal of Salt Lake Research 5, no 2: 131 (26 pages).

Maguire, P.K.H., C.J. Ebinger et al. (2003). "Geophysical project in Ethiopia studies continental breakup." EOS (Transactions, American Geophysical Union), 84 (35): 337, 342-343

Matheson, F. J. (1966 Geology of the Kajiado area; degree sheet 51, S.E. quarter. Nairobi, Republic of Kenya, Mines and Geological Department: 51.

Mboya, B. (1986). "Geological application of Landsat data in mapping the distribution of late Tertiary and Quaternary sediments in the Kenya Rift Valley." Proceedings of the Twentieth international symposium on Remote sensing of environment Proceedings of the International Symposium on Remote Sensing of Environment 20(1-3): 899-906.

McBrearty, S. and N. G. Jablonski (2005). "First fossil chimpanzee." Nature 437(7055): 105 (4 pages).

McDougall, I. and R. T. Watkins (2006). "Geochronology of the Nabwal Hills; a record of earliest magmatism in the northern Kenyan Rift valley." Geological Magazine 143(1): 25-39.

McNitt, J.R., C.W. Klein, J.B. Koenig (1989). "Probably subsurface temperature at Lake Magadi, Kenya, as indicated by hot spring geochemistry, and the potential for development of geothermal electric power". National Geothermal Association. Report on the Pre-feasibility power generation study for the Magadi Soda Company Magadi, Kenya. (1989) US Department of Energy contract number DE-FG07-89ID12850: 105 pp. Retrieved Aug 3, 2007 from <www.osti.gov>

Mora, R., M. Dominguez-Rodrigo, et al. (2003). "The Archaeology of the Peninj "St Complex" (Lake Natron, Tanzania)." Treballs d'Arqueologia 9(Oldowan: Rather more than smashing stones; First hominid technology workshop): 41.

Ndetei, R. and V. S. Muhandiki (2005). "Mortalities of lesser flamingos in Kenyan Rift Valley saline lakes and the implications for sustainable management of the lakes." Lakes \& Reservoirs: Research and Management 10, no 1: 51-58.

Nyblade, A. A. and R. A. Brazier (2002). "Precambrian lithospheric controls on the development of the East African Rift system." Geology (Boulder) 30(8): 755-758. 
A. Guth, MS Thesis, 2007

Nyblade, A. A., M. T. Dugda, et al. (2004). "Crust and Upper Mantle Structure of the East African Rift System." Conference: THE EAST AFRICAN RIFT SYSTEM: DEVELOPMENT, EVOLUTION AND RESOURCES Retrieved April 18, 2007, from http://www.gl.rhul.ac.uk/ear_conference/.

Nyblade, A. A. and C. A. Langston (2002). "Broadband seismic experiments probe the East African Rift." Eos, Transactions, American Geophysical Union 83(37): 405, 408-409.

Nyblade, A. A. (2002). "Crust and upper mantle structure in East Africa; implications for the origin of Cenozoic rifting and volcanism and the formation of magmatic rifted margins", Volcanic Rifted Margins Eds. M. A. Menzies, et al. Geological Society of America (GSA), Special Paper 362: 15-26

Otando, S. W. (2004). An engineering geological characterisation of tropical clays : case study ; clay soils of Nairobi, Kenya. Clausthal-Zellerfeld, Germany, Technische Universität Clausthal. Doctor of Natural Science: 218.

Owen, R. B. and R. W. Renaut (1981). "Palaeoenvironments and sedimentology of the middle Pleistocene Olorgesailie Formation, southern Kenya Rift valley." Palaeoecology of Africa and the surrounding islands Palaeoecology of Africa and of the Surrounding Islands and Antarctica 13: 147-174.

Owen, R. B., R. W. Renaut, et al., Eds. (2000). Spatial and temporal facies variations in the Pleistocene Olorgesailie Formation, southern Kenya Rift valley, American Association of Petroleum Geologists, Tulsa, OK.

Patel, J. P. and P. K. S. Raja (1979). "Paleomagnetic results from the Narosura and Magadi volcanics of Kenya." Physics of the Earth and Planetary Interiors 19(3): P7-P14.

Poland, M. P. (2006) "InSAR Captures Rifting and Volcanism in East Africa." Alaska Satellite Facility News \& Notes Volume, 1 and 3 DOI:

Potts, R., A. K. Behrensmeyer, et al. (2004). "Small mid-Pleistocene hominin associated with East African Acheulean technology." Science 305(5680): 75-78.

Potts R., Deino A. (1995). "Mid-Pleistocene change in large mammal faunas of East Africa" Quaternary Research 43, no.1: 106-113

Potts R. ; Shipman P. ; Ingall E. (1988) “Taphonomy, paleoecology, and hominids of Lainyamok, Kenya" Journal of Human Evolution 17, no.6: 597-614

Prodehl, C., J. R. R. Ritter, et al., (1997). "The KRISP 94 lithospheric investigation of southern Kenya; the experiments and their main results", Ed. K. Fuchs, R. Altherr et al., Tectonophysics, vol.278, no.1-4: 121-147.

Randel, R. P. and R. W. Johnson (1991). Geology of the Suswa Area; Degree Sheet 51, N.W. quarter. Nairobi, Republic of Kenya, Mines and Geological Department.

Roberts, N., M. Taieb, et al. (1993). "Timing of the Younger Dryas event in East Africa from lake-level changes." Nature (London) 366(6451): 146-148.

Rogers, N. (2004). "Basalt Geochemistry, Mantle Plumes and the East African Rift." Conference: THE EAST AFRICAN RIFT SYSTEM: DEVELOPMENT, EVOLUTION AND RESOURCES Retrieved April 18, 2007, from http://www.gl.rhul.ac.uk/ear_conference/.

Saggerson, E. P. (1991). Geology of the Nairobi Area; degree sheet 51, N.E. quarter, Republic of Kenya, Mines and Geological Department. 
Schubel, K. A. and B. M. Simonson (1990). "Petrography and Diagenesis of Cherts from Lake Magadi, Kenya." Journal of sedimentary petrology 60(5): 761-776.

Shipman, P., R. Potts, et al. (1983). "Lainyamok, a new middle Pleistocene hominid site." Nature (London) 306(5941): 365-368.

Sigmundsson, F. (2006). "Plate tectonics: Magma does the splits." Nature 442(7100): 251-252.

Simiyu, S. M. and G. R. Keller (1998). "Upper crustal structure in the vicinity of Lake Magadi in the Kenya Rift Valley region." Journal of African earth sciences 27(3): 359 (14 pages).

Simiyu, S. M. and G. R. Keller (2001). "An integrated geophysical analysis of the upper crust of the southern Kenya Rift." Geophysical Journal International 147(3): 543-561.

Skilling, I. P. (1993). "Incremental caldera collapse of Suswa Volcano, Gregory Rift Valley, Kenya." Journal of the Geological Society of London 150: 885-896.

Smith, M. (1994). "Stratigraphic and structural constraints on mechanisms of active rifting in the Gregory Rift, Kenya." Ed. C. Prodehl, G.R. Keller et al. Tectonophysics 236: 3-22.

Surdam, R. C. and H. P. Eugster (1976). "Mineral reactions in the sedimentary deposits of the Lake Magadi region, Kenya." Geological Society of America Bulletin 87(12): 17391752.

Symonds, R. B., W. I. Rose, et al. (1994). Volcanic-Gas Studies: Methods, Results, and Applications. VOLATILES IN MAGMAS. M. R. C. a. J. R. Holloway, Mineralogical Society of America. 30: 1-66.

Thiessen, R., K. Burke, et al. (1979). "African hotspots and their relation to the underlying mantle." Geology (Boulder) 7(5): 263-266.

Thompson, J. B. and F. G. Ferris (1990). "Cyanobacterial precipitation of gypsum, calcite, and magnesite from natural alkaline lake water." Geology (Boulder) 18(10): 995-998.

Thouveny, N. and M. Taieb (1986). "Preliminary magnetostratigraphic record of Pleistocene deposits, Lake Natron basin; Tanzania." Sedimentation in the African rifts Geological Society Special Publications 25: 331-336.

Trauth, M. H., A. L. Deino, et al. (2003). "East African climate change and orbital forcing during the last 175 kyr BP." Earth and Planetary Science Letters 206(3-4): 297-313.

Trauth, M. H., M. A. Maslin, et al. (2005). "Late Cenozoic moisture history of East Africa." Science 309(5743): 2051-2053.

Walsh, J. (1969). "Mineral and thermal waters of Kenya." Mineral and thermal waters of the world; B, Oversea countries Report of the ... Session - International Geological Congress 19: $105-110$.

Walsh, P. J., M. Grosell, et al. (2001). "Review - Physiological and molecular characterization of urea transport by the gills of the Lake Magadi tilapia (Alcolapia grahami)." The journal of experimental biology 204(3): 509 (12 pages).

Weeraratne, D. S., D. W. Forsyth, et al. (2003). "Evidence for an upper mantle plume beneath the Tanzanian Craton from Rayleigh wave tomography." Journal of Geophysical Research 108.

White, T. D., G. Woldegabriel, et al. (2006). "Asa Issie, Aramis and the origin of Australopithecus." Nature 440(7086): 883 (7 pages).

Wilkinson, A. F. (1988). Geology of the Allia Bay area : degree sheet 11, with coloured 1:250 000 geological map. Nairobi, Ministry of Environment and Natural Resources, Mines and Geology Dept.

Williams, L.A.J. (1967) "Geology" Nairobi: city and region. Ed. Morgan, W. T. W. Nairobi, New York, Oxford University Press. 1-13 
Williams, L. A. J. and P. H. Truckle (1980). "Volcanic sequences in the Kenya Rift." Atti dei Convegni Lincei, Accademia Nazionale dei Lincei 47: 123-132.

Williamson, D., M. Taieb, et al. (1993). "Equatorial Extension of the younger Dryas event: rock magnetic evidence from Lake Magadi (Kenya)." Global and planetary change 7(1-3): 235.

Wilson, P., C. Wood, et al. (2000). "Genetic structure of Lake Magadi tilapia populations." Journal of Fish Biology 56, no 3: 590 (14 pages).

Wilson, P. J., H. L. Bergman, et al. (2004). "Discordance between genetic structure and morphological, ecological, and physiological adaptation in Lake Magadi tilapia." Physiological and Biochemical Zoology 77(4): 537-555.

Wynn, J. G., Z. Alemseged, et al. (2006). "Geological and palaeontological context of a Pliocene juvenile hominin at Dikika, Ethiopia." Nature 443(7109): 332 (5 pages).

Yager, T. R. (2004). "The Mineral Industry of Kenya." Minerals Yearbook, Vol III Retrieved April 17, 2007, from http://minerals.usgs.gov/minerals/pubs/country/africa.html.

Zhilina, T. N., E. N. Detkova, et al. (1998). "Natronoincola histidinovorans gen. nov., sp. nov., a New Alkaliphilic Acetogenic Anaerobe." Current Microbiology 37(3): 177-185.

Zhilina, T. N., E. S. Garnova, et al. (2001). "Amphibacillus fermentum sp. nov. and Amphibacillus tropicussp. nov., New Alkaliphilic, Facultatively Anaerobic, Saccharolytic Bacilli from Lake Magadi." Microbiology 70(6): 711-722.

Zhilina, T. N., E. S. Garnova, et al. (2001). "Halonatronum saccharophilum gen. nov. sp. nov.: A New Haloalkaliphilic Bacterium of the Order Haloanaerobiales from Lake Magadi." Microbiology 70(1): 64-72.

Zhilina, T. N., G. A. Zavarzin, et al. (1996). "Spirochaeta alkalica sp. nov., Spirochaeta africana sp. nov., and Spirochaeta asiatica sp. nov., alkaliphilic anaerobes from the Continental Soda Lakes in Central Asia and the East African Rift." Int J Syst Bacteriol 46(1): 305-312.

\section{Other relevant works}

\section{Biology}

Behrensmeyer, A. K. (2006). "Climate change and human evolution." Science 311(5760): 476-478.

Cocquyt, C. and W. Vyverman (2005). "Phytoplankton in Lake Tanganyika: A comparison of community composition and biomass off Kigoma with previous studies 27 years ago." Journal of Great Lakes research 31(4): 535 (12 pages).

DasSarma, S. and A. P. (2001). "Halophiles." Encyclopedia of Life Sciences: 1-9.

Ghauri, M. A., A. M. Khalid, et al. (2006). "Phylogenetic Analysis of Bacterial Isolates from Man-Made High-pH, High-Salt Environments and Identification of Gene-CassetteAssociated Open Reading Frames." Current Microbiology 52(6): 487-492.

Gierlowski-Kordesch, E. H. and L. E. Park (2004). "Comparing species diversity in the modern and fossil record of lakes." Paleoecology, paleogeography, and paleoclimatology; recent contributions honoring A. M. Ziegler Journal of Geology 112(6): 703-717. 
Iteman, I., R. Rippka, et al. (2002). "rDNA analyses of planktonic heterocystous cyanobacteria, including members of the genera Anabaenopsis and Cyanospira." Microbiology 148: 481-496.

Leakey, M. D., R. L. Hay, et al. (1978). Fossil hominids from the Laetoli Beds, Tanzania. Geological Background to Fossil Man. W. W. Bishop, Scott. Acad. Press, Edinburgh, United Kingdom: 157-170.

Tichy, H. and L. Seegers (1999). "The Oreochromis alcalicus flock (Teleostei: Cichlidae) from lakes Natron and Magadi, Tanzania and Kenya: a model for the evolution of 'new' species flocks in historical times?" Ichthyological exploration of freshwaters 10: 147-174.

Vadim, V. K., N. Z. Tatjana, et al. (1998). "Tindallia magadii gen. nov., sp. nov.: An Alkaliphilic Anaerobic Ammonifier from Soda Lake Deposits." Current Microbiology 37(2): 94-100.

Verschuren, D., C. Cocquyt, et al. (1999). "Long-term dynamics of algal and invertebrate communities in a small, fluctuating tropical soda lake." Limnology and oceanography 44(5): 1216 (16 pages).

Westall, F., M. J. de Wit, et al. (2001). "Early Archean fossil bacteria and biofilms in hydrothermally-influenced sediments from the Barberton greenstone belt, South Africa." Precambrian research 106(1): 93 (24 pages).

\section{Climate Change and Geochronology}

Barry, S. L., M. L. Filippi, et al. (2002). Sedimentology and Geochronology of Late Pleistocene and Holocene Sediments from Northern Lake Malawi. The East African great lakes: limnology, palaeolimnology, and biodiversity. E. O. Odada and D. O. Olago, Kluwer Academic Publishers. 12: 369-391.

Cahen, L., N. J. Snelling, et al. (1984). The geochronology and evolution of Africa, Oxford, Clarendon Press, United Kingdom.

Charsley, T. J. (1987). Geology of the North Horr area; degree sheet 12 with coloured 1:250,000 geological map. Nairobi, Ministry of Environment and Natural Resources, Mines and Geology Dept.

Curtis, G. H., R. E. Drake, et al. (1978). Age of KBS Tuff in Koobi Fora Formation, East Lake Turkana, Kenya. Geological Background to Fossil Man. W. W. Bishop, Scott. Acad. Press, Edinburgh, United Kingdom: 463-469.

Damnati, B. and M. Taieb (1995). "Solar and ENSO signatures in laminated deposits from Lake Magadi (Kenya) during the Pleistocene/Holocene transition." Journal of African earth sciences 21(3): 373 (10 pages).

Damnati, B., M. Taieb, et al. (1992). "Laminated deposits from Lake Magadi (Kenya); climatic contrast effect during the maximum wet period between 12,000-10,000 yrs BP." Bulletin de la Societe Geologique de France, Huitieme Serie 163(4): 407-414.

Hilaire-Marcel, C., J. Casanova, et al., Eds. (1988). Isotopic age and lacustrine environments during late Quaternary in the Tanzanian Rift (Lake Natron), Van Nostrand Reinhold Co., New York, NY.

Isaac, G. L. (1978). The Olorgesailie Formation; stratigraphy, tectonics and the palaeogeographic context of the middle Pleistocene archaeological sites. Geological Background to Fossil Man. W. W. Bishop, Scott. Acad. Press, Edinburgh, United Kingdom: 173-206. 
Johnson, T. C., E. T. Brown, et al. (2002). "A high-resolution paleoclimate record spanning the past 25,000 years in southern East Africa." Science 296(5565): 113-114, 131-132.

Sturchio, N. C., P. N. Dunkley, et al. (1993). "Climate-driven variations in geothermal activity in the northern Kenya Rift valley." Nature (London) 362(6417): 233-234.

Thompson, L. G., E. Mosley-Thompson, et al. (2002). "Kilimanjaro ice core records; evidence of Holocene climate change in tropical Africa." Science 298(5593): 589593.

Trautmann, T., A. Dietrich, et al. (1999). "Radioluminescence dating; a new tool for Quaternary geology and archaeology." Naturwissenschaften 86(9): 441-444.

Tryon, C. A. and S. McBrearty (2006). "Tephrostratigraphy of the Bedded Tuff Member (Kapthurin Formation, Kenya) and the nature of archaeological change in the later middle Pleistocene." Quaternary Research 65(3): 492-507.

Wilkinson, P., J. G. Mitchell, et al. (1986). "Volcanic chronology of the Meru-Killimanjaro region, northern Tanzania." Journal of the Geological Society of London 143(4): 601605.

\section{Geochemistry}

Abruzzese, M. J., J. R. Waldbauer, et al. (2005). "Oxygen and hydrogen isotope ratios in freshwater chert as indicators of ancient climate and hydrologic regime." Geochimica et Cosmochimica Acta 69(6): 1377-1390.

Eugster, H. P. (1966). "Sodium carbonate-bicarbonate minerals as indicators of P (sub carbon dioxide)." Journal of Geophysical Research 71(14): 3369-3377.

Eugster, H. P. (1984). "Geochemistry and sedimentology of marine and nonmarine evaporates". Eclogae Geologicae Helvetiae 77(2): 237-248.

Fontes, J. C. and J. N. Andrews (1993). "Comment on "The \{ sup $36 \mathrm{Cl}$ ages of the brines in the Magadi-Natron basin, East Africa" by A. Kaufman et al." Geochimica et cosmochimica acta 57(7): 1607.

Fontes, J. C. and J. N. Andrews (1993). "Response to the Reply by A. Kaufman et al. on "The $\{$ sup $36 \mathrm{Cl}$ ages of the brines in the Magadi-Natron basin, East Africa"." Geochimica et cosmochimica acta 57(7): 1618.

Jones, B. F., H. P. Eugster, et al. (1977). "Hydrochemistry of the Lake Magadi Basin, Kenya." Geochimica et Cosmochimica Acta 41(1): 53-72.

Kaufman, A. (1993). "Response to the Comment by J.-Ch. Fontes and J. N. Andrews on "The \{sup\}36Cl ages of the brines in the Magadi-Natron basin, East Africa"." Geochimica et cosmochimica acta 57(7): 1618.

Kaufman, A., M. Magaritz, et al. (1993). "Reply to Comment by J.-Ch. Fontes and J. N. Andrews on "The \{ sup $36 \mathrm{Cl}$ ages of brines in the Magadi-Natron basin, East Africa"." Geochimica et cosmochimica acta 57(7): 1613.

Kaufman, A., M. Magaritz, et al. (1990). "The sup $36 \mathrm{Cl}$ ages of the brines in the Magadi-Natron basin, East Africa." Geochimica et cosmochimica acta 54(10): 2827-2834.

Kerrich, R., R. W. Renaut, et al., Eds. (2002). Trace-element composition of cherts from alkaline lakes in the East African Rift; a probe for ancient counterparts, Society for Sedimentary Geology (SEPM), Tulsa, OK. 
Kusakabe, M., G. Z. Tanyileke, et al., Eds. (2000). Recent pH and CO (sub 2) profiles at Lakes Nyos and Monoun, Cameroon; implications for the degassing strategy and its numerical simulation, Elsevier, Amsterdam, Netherlands.

Muraishi, H. (1995). "Experimental Study of Amorphous Silica Crystallization in Na2CO3$\mathrm{NaHCO} 3$ Solutions as a Source of Chert Formation in Lake Magadi." Bulletin of the Chemical Society of Japan 68(11): 3027 (8 pages).

Nielsen and Dahi (2002). "Fluoride exposure of East African consumers using alkaline salt deposits known as magadi (trona) as a food preparation aid." Food Additives and Contaminants 19, no 8: 709-714.

Nielsen, J. M. (1999). "East African magadi (trona): Fluoride concentration and mineralogical composition." Journal of African earth sciences 29(2): 423.

O'Neil, J. R. and R. L. Hay (1973). "(super 18) O/ (super 16) O ratios in cherts associated with the saline lake deposits of East Africa." Earth and Planetary Science Letters 19(2): 257266.

\section{Plumes and Structure}

Arndt, N. (2000). "Hot heads and cold tails." Nature (London) 407(6803): 458-459, 461.

Baker, B. H. (1971). "Explanatory note on the structure of the southern part of the African rift system." Earth Science (Paris) 6: 543-548.

Bosworth, W., K. Burke, et al. (2000) "Magma chamber elongation as an indicator of intraplate stress field orientation: "borehole break-out mechanism" and examples from the Late Pleistocene to Recent Kenya Rift Valley." Journal of the Virtual Explorer Volume, DOI

Jerram, D. A., M. A. Menzies, et al., Eds. (2002). Volcanology and facies architecture of flood basalts, Geological Society of America (GSA), Boulder, CO.

Kaszuba, J. P. and R. F. Wendlandt (2000). "Effect of carbon dioxide on dehydration melting reactions and melt compositions in the lower crust and the origin of alkaline rocks." Journal of Petrology 41(3): 363-386.

King, B. C. (1978). Structural and volcanic evolution of the Gregory Rift valley. Geologic Background to Fossil Man. W. W. Bishop, Scott. Acad. Press, Edinburgh, United Kingdom: 29-54.

Koepenick, K. W., S. L. Brantley, et al. (1996). "Volatile emissions from the crater and flank of Oldoinyo Lengai Volcano, Tanzania." Journal of Geophysical Research 101(B6): 13,81913,830 .

Le Turdu, C., J. J. Tiercelin, et al., Eds. (1999). Influence of preexisting oblique discontinuities on the geometry and evolution of extensional fault patterns; evidence from the Kenya Rift using SPOT imagery, American Association of Petroleum Geologists, Tulsa, OK.

Macdonald, R., B. A. Kjarsgaard, et al. (1993). "Liquid immiscibility between trachyte and carbonate in ash flow tuffs from Kenya." Contributions to Mineralogy and Petrology 114(2): 276-287.

Marcelot, G., C. Dupuy, et al. (1989). "Geochemistry of mafic volcanic rocks from the Lake Kivu (Zaire and Rwanda) section of the western branch of the African Rift." Journal of Volcanology and Geothermal Research 39(1): 73-88. 
McClay, K. R., compiler, et al. (2002). Recent advances in analogue modelling; uses in section interpretation and validation. Extensional tectonics; faulting and related processes. R. E. Holdsworth, J. P. Turner, compiler and compiler, Publisher Geological Society London, London, United Kingdom: 185-209.

McKenzie, D. and M. J. Bickle (1988). "The volume and composition of melt generated by extension of the lithosphere." Journal of Petrology 29(3): 625-679.

Mugisha, F., C. J. Ebinger, et al., Eds. (1997). "Two-stage rifting in the Kenya Rift; implications for half-graben models." Tectonophysics 278(no 1-4): 63-81.

Pallister, J. W. (1971). The tectonics of East Africa. "The tectonics of East Africa." Earth Science (Paris) 6: 511-542.

Rogers, N. W., P. J. Evans, et al. (2004). "Rates and timescales of fractional crystallization from (super 238) U- (super 230) Th- (super 226) Ra disequilibria in trachyte lavas from Longonot Volcano, Kenya." Journal of Petrology 45(9): 1747-1776.

Rykounov, L. N., V. V. Sedov, et al. (1972). "Study of microearthquakes in the rift zones of east Africa." East African Rifts Tectonophysics 15(1-2): 123-230.

Saal, A. E., E. H. Hauri, et al. (2002). "Vapour undersaturation in primitive mid-ocean-ridge basalt and the volatile content of Earth's upper mantle." Nature 419(6909): 451 (5 pages).

Saggerson, E. P. and B. H. Baker (1965). "Post-Jurassic erosion surfaces in eastern Kenya and their deformation in relation to rift structure." Quarterly Journal of the Geological Society of London 121: 51-72.

Scaillet, B. and R. Macdonald (2003). "Experimental constraints o $\mathrm{n}$ the relationships between peralkaline rhyolites of the Kenya Rift valley." Journal of Petrology 44(10): 1867-1894.

Shackleton, R. M. (1978). Geological map of the Olorgesailie area, Kenya. Geological background to fossil man; recent research in the Gregory Rift valley, East Africa. W. W. Bishop, Scott. Acad. Press, Edinburgh, United Kingdom: 171.

Spath, A., A. P. Le Roex, et al. (2001). "Plume-lithosphere interaction and the origin of continental rift-related alkaline volcanism; the Chyulu Hills volcanic province, southern Kenya." Journal of Petrology 42(4): 765-787.

Tesfaye, S., D. J. Harding, et al. (2003). "Early continental breakup boundary and migration of the Afar triple junction, Ethiopia." Bulletin of the Geological Society of America 115(9): 1053-1067.

Williams, L. A. J. (1963). "Lava tunnels on Suswa mountain, Kenya." Nature (London) 199(4891): 348-350.

Williams, L. A. J. (1972). "The Kenya rift volcanics; a note on volumes and chemical composition." East African Rifts Tectonophysics 15(1-2): 83-96.

Williams, L. A. J. (1978). Character of Quaternary volcanism in the Gregory Rift valley, Geological background to fossil man; recent research in the Gregory rift valley, East Africa. Ed. W. W. Bishop, Scott. Acad. Press, Edinburgh, United Kingdom: 55-69

Wohlenberg, J. and N. V. Bhatt (1972). "Report on airmagnetic surveys of two areas in the Kenya Rift Valley." East African Rifts Tectonophysics 15(1-2): 143-149.

\section{Sedimentation}

Adams, D. D. and S. O. Ochola (2002). A Review of Sediment Gas Cycling in Lakes with reference to Lake Victoria and Sediment Gas Measurements in Lake Tanganyika. The East African great lakes : limnology, palaeolimnology, and biodiversity. E. O. Odada and 
D. O. Olago, Kluwer Academic Publishers. 12: 277-305.

Eugster, H. P. (1986). "Lake Magadi, Kenya; a model for rift valley hydrochemistry and sedimentation?" Sedimentation in the African rifts Geological Society Special Publications 25: 177-189.

Frostick, L. E. (1997). The East African Rift basins. African Basins. Sedimentary Basins of the World. R. C. Selley, Elsevier, Amsterdam. 3: 187-209.

Hinman, N. W., R. F. Lindstrom, et al., Eds. (1996). Seasonal changes in silica deposition in hot spring systems, Elsevier, Amsterdam, Netherlands.

Icole, M. and G. Perinet (1984). "Les silicates sodiques et les milieux evaporitiques carbonates bicarbonates sodiques: une revue". Revue de Geologie Dynamique et de Geographie Physique 25(3): 167-176.

Krainer, K. and A. Spotl (1998). "Abiogenic silica layers within a fluvio-lacustrine succession, Bolzano Volcanic Complex, northern Italy: a Permian analogue for Magadi-type cherts?" SEDIMENTOLOGY 45, no 3: 489.

Laerdal, T., M. R. Talbot, et al. (2002). Late Quaternary sedimentation and climate in the Lake Edward and George area, Uganda-Congo. The East African great lakes : limnology, palaeolimnology, and biodiversity. E. O. Odada and D. O. Olago, Kluwer Academic Publishers. 12: 429-470.

Renaut, R. W., B. Jones, et al. (2002). "Sublacustrine precipitation of hydrothermal silica in rift lakes; evidence from Lake Baringo, central Kenya Rift Valley."

Sedimentary Geology 148(no 1-2): 235-257.

Sebag, D., A. Durand, et al. (2001). "The natural hydrous sodium silicates from the northern bank of Lake Chad: Occurrence, petrology and genesis." Sedimentary Geology 139(1): $15-31$.

Smith, B. J. and J. J. McAlister (1986). "Observations on the occurence and origins of salt weathering phenomena near Lake Magadi, southern Kenya." Zeitschrift fuer Geomorphologie 30(4): 445-460.

Surdam, R. C., H. P. Eugster, et al. (1972). "Magadi-Type Chert in Jurassic and Eocene to Pleistocene Rocks, Wyoming." Geological Society of America Bulletin 83(8): 2261-2265.

Taieb, M., P. Barker, et al. (1991). "Histoire paleohydrologique du lac Magadi (Kenya) au Pleistocene superieur." C.R. Acad. Sci. Paris, Serie II 313(3): 339-346.

Tiercelin, J. J., C. A. Kogbe, et al. (1990). "Rift-basin sedimentation; responses to climate, tectonism and volcanism; examples of the East African Rift." Journal of African Earth Sciences 10(no 1-2): 283-305.

Tiercelin, J. J. and K. E. Lezzar (2002). A 300 Million Years History of Rift Lakes in Central and East Africa: An Updated Broad Review. The East African great lakes : limnology, palaeolimnology, and biodiversity. Eds. E. O. Odada and D. O. Olago, Kluwer Academic Publishers: 3-60

Vincens, A. and J. Casanova (1987). "Modern background of Natron-Magadi Basin (TanzaniaKenya): physiography, climate, hydrology and vegetation." Sciences Geologiques Bulletin 40(1-2): 9-21. 
A. Guth, MS Thesis, 2007

\section{Appendix A: Figures}


A. Guth, MS Thesis, 2007

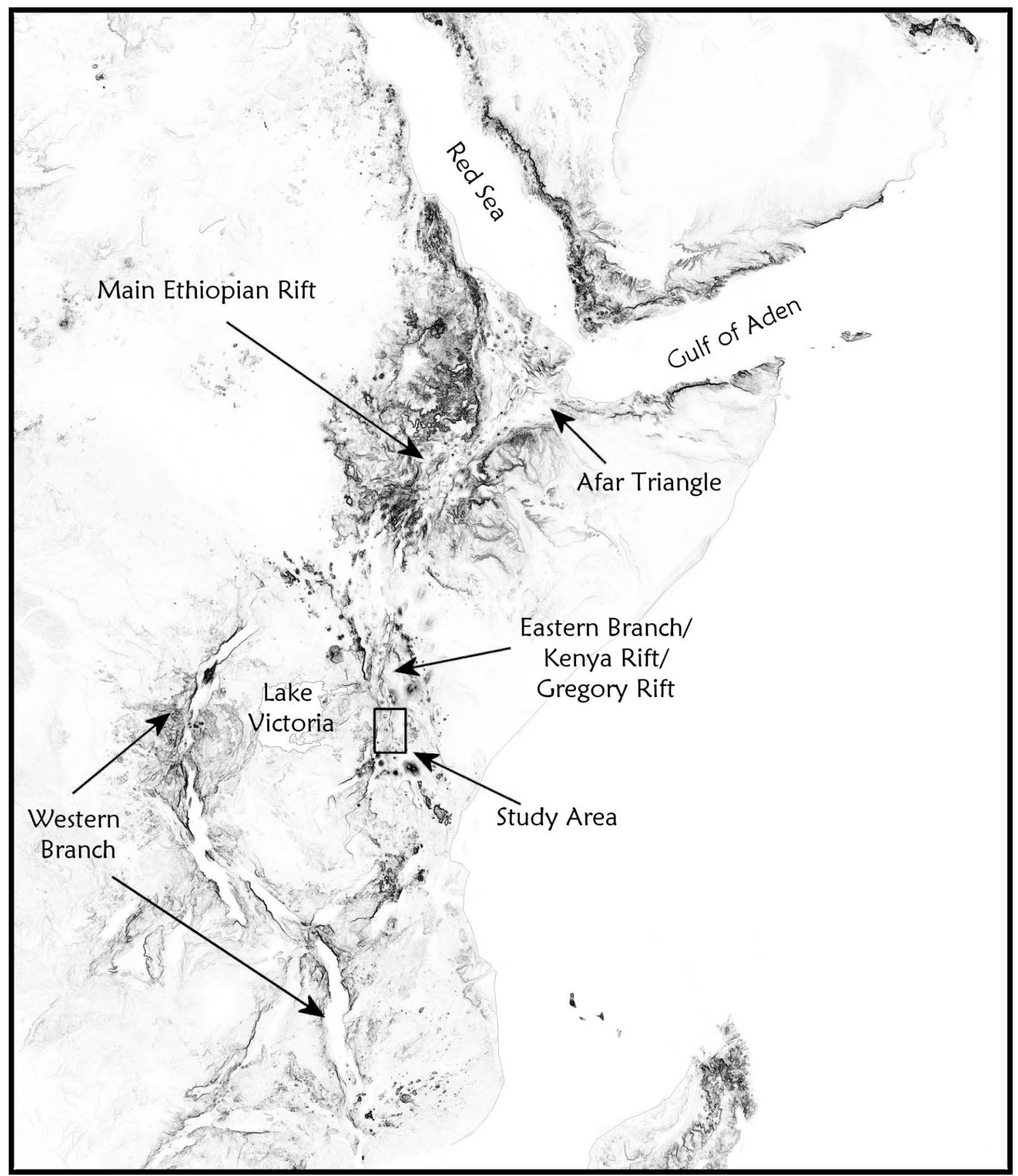

Figure 1: Shaded Digital Elevation Model (DEM) of Eastern Africa showing the rift system. To the north, the typical three-arm rift is apparent with two of the arms already having been flooded to form the Red Sea and the Gulf of Aden and with the third arm going to the south as the Main Ethiopian Rift. This branch splits around the Lake Victoria region to form the Eastern and Western branches, with the study area being a part of the Eastern Branch. 


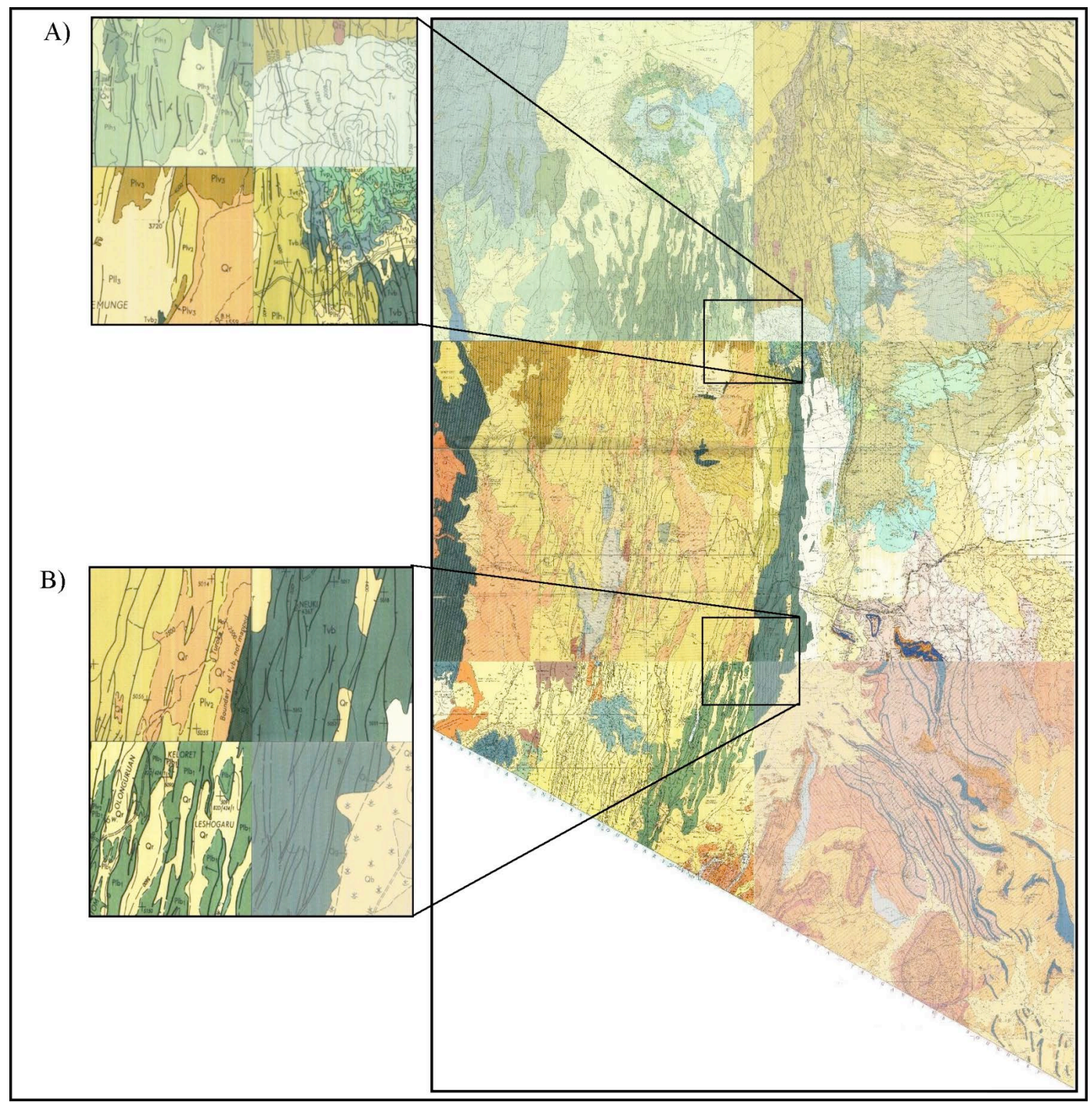

Figure 2: Assemblage of Kenya Geological Survey (1958-1991) maps on the right covering the study area. Note the changes in detail and color across map boundaries. Enlargements are shown to highlight such changes. A) shows the intersection of the northern four maps (clockwise from upper left: Suswa, Nairobi, Magadi and Kajiado maps) B) is the intersection of the southern four (clockwise from upper left: Magadi, Kajiado, South Magadi and Namanga maps). 
A. Guth, MS Thesis, 2007

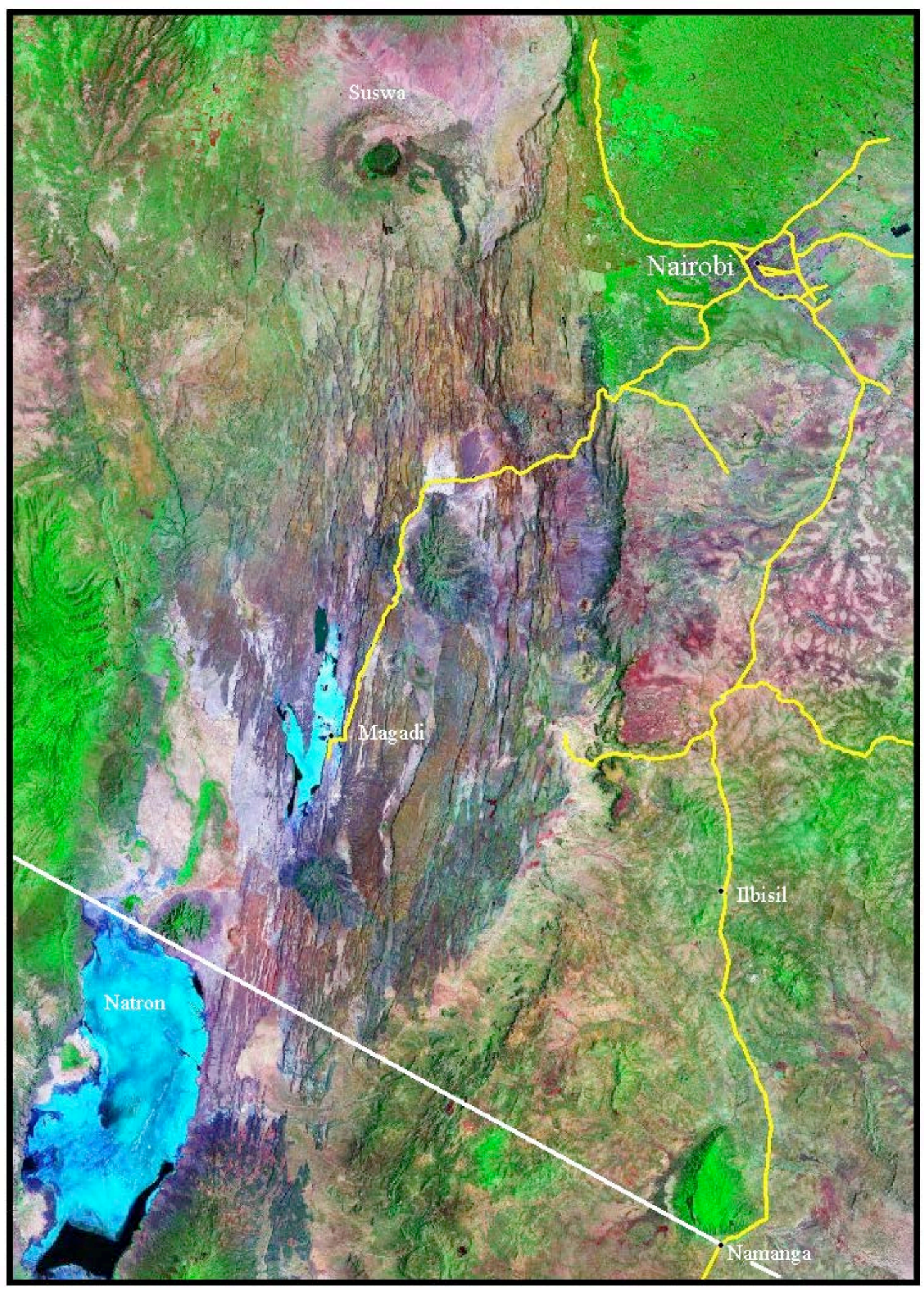

Figure 3: A false-color Landsat image of the study area obtained from the NASA GeoCover web site showing roads (yellow), the Kenya-Tanzania border (white) and selected towns and features. 
A. Guth, MS Thesis, 2007

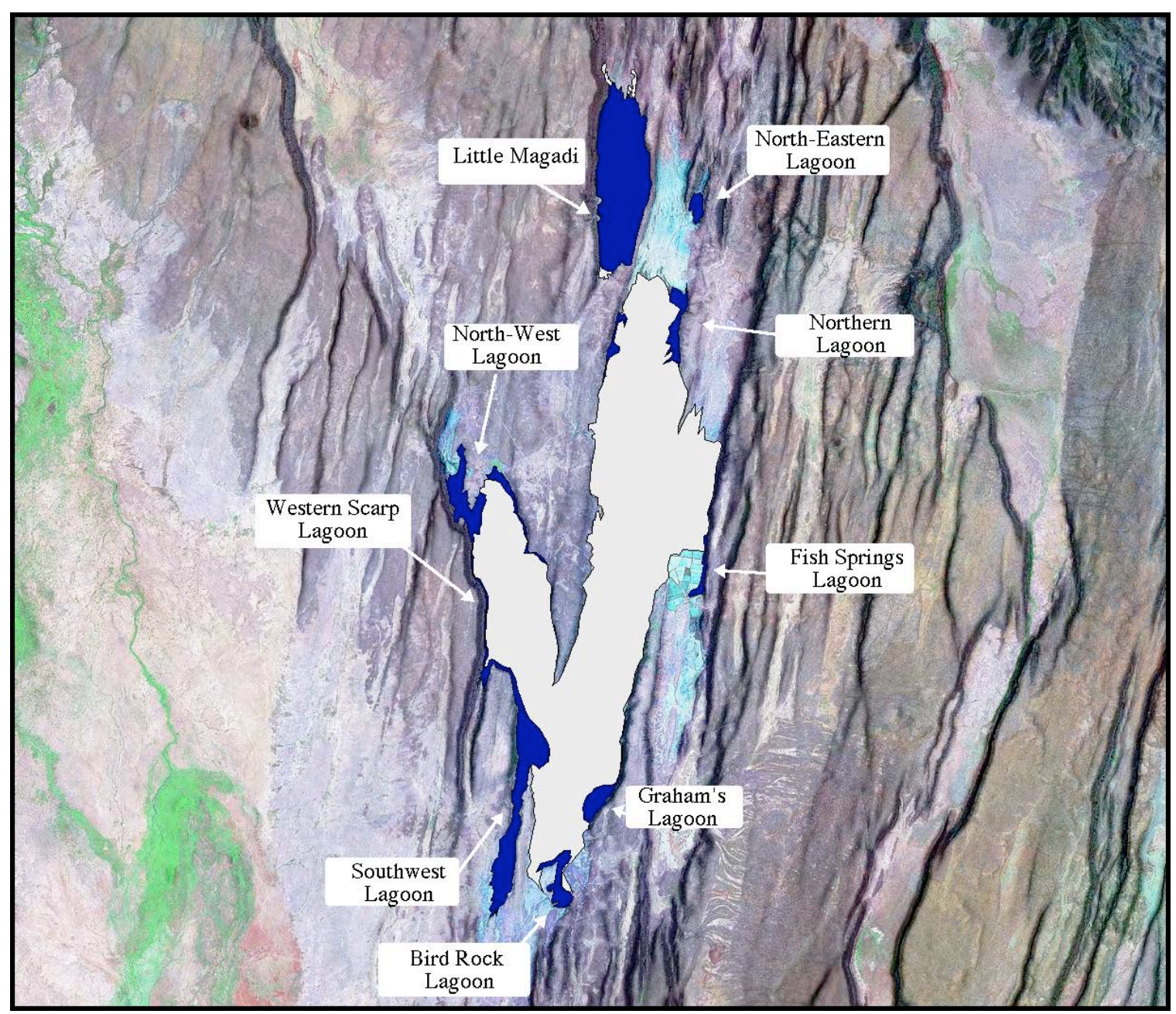

Figure 4: False color Landsat image draped over a DEM to emphasize the fault scarps and their relation to the lagoons (labeled after Baker 1958) surrounding Lake Magadi. 
A. Guth, MS Thesis, 2007

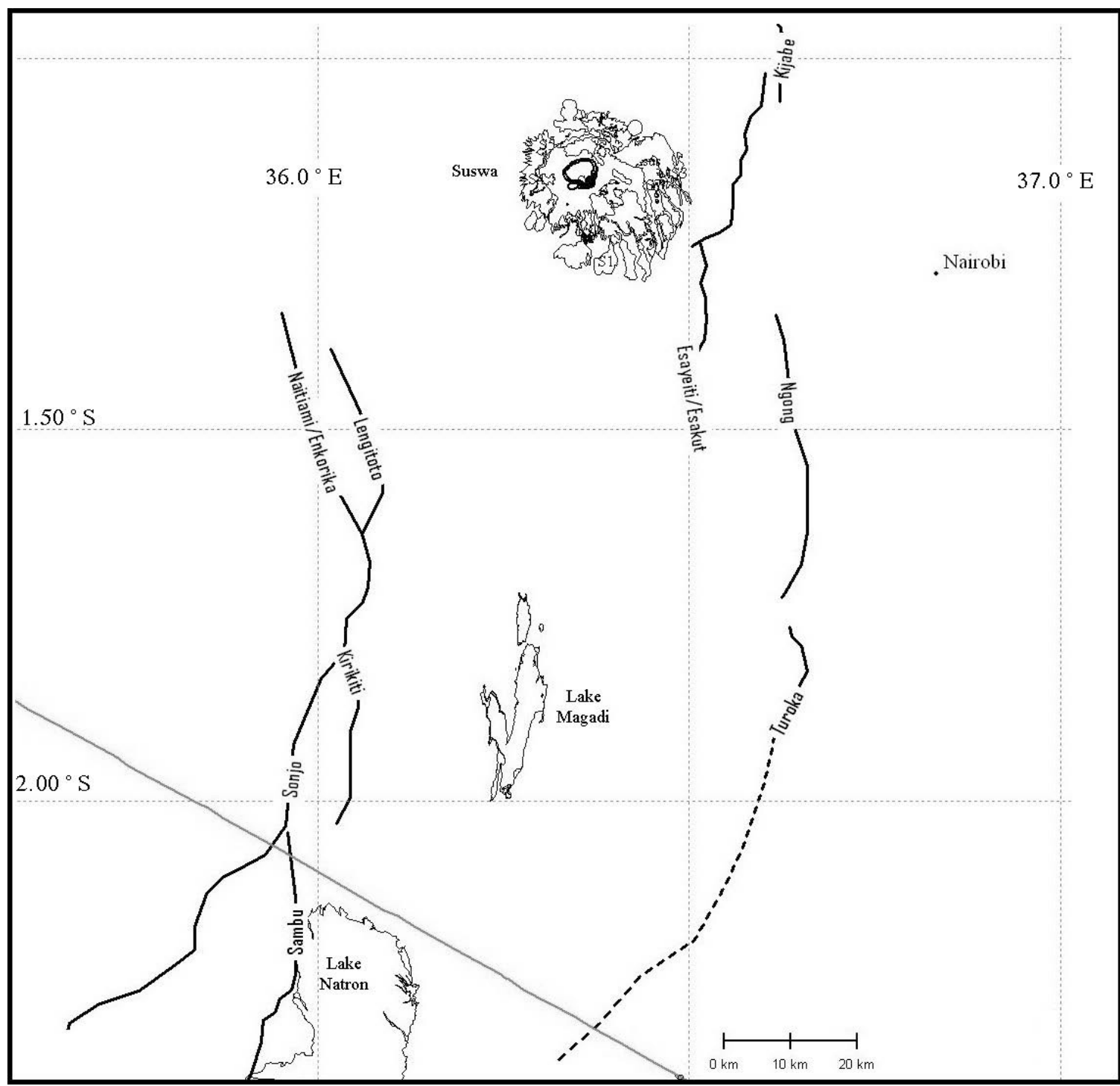

Figure 5: Map of the Southern Kenya Rift showing the major, named, rift bounding faults. Also shown are the outlines of Suswa, a shield volcano in the northern part of the study area, and Lakes Magadi and Natron. The grey line running diagonally through the image between the two lakes is the Kenya-Tanzania border. Nairobi is also shown for reference. 


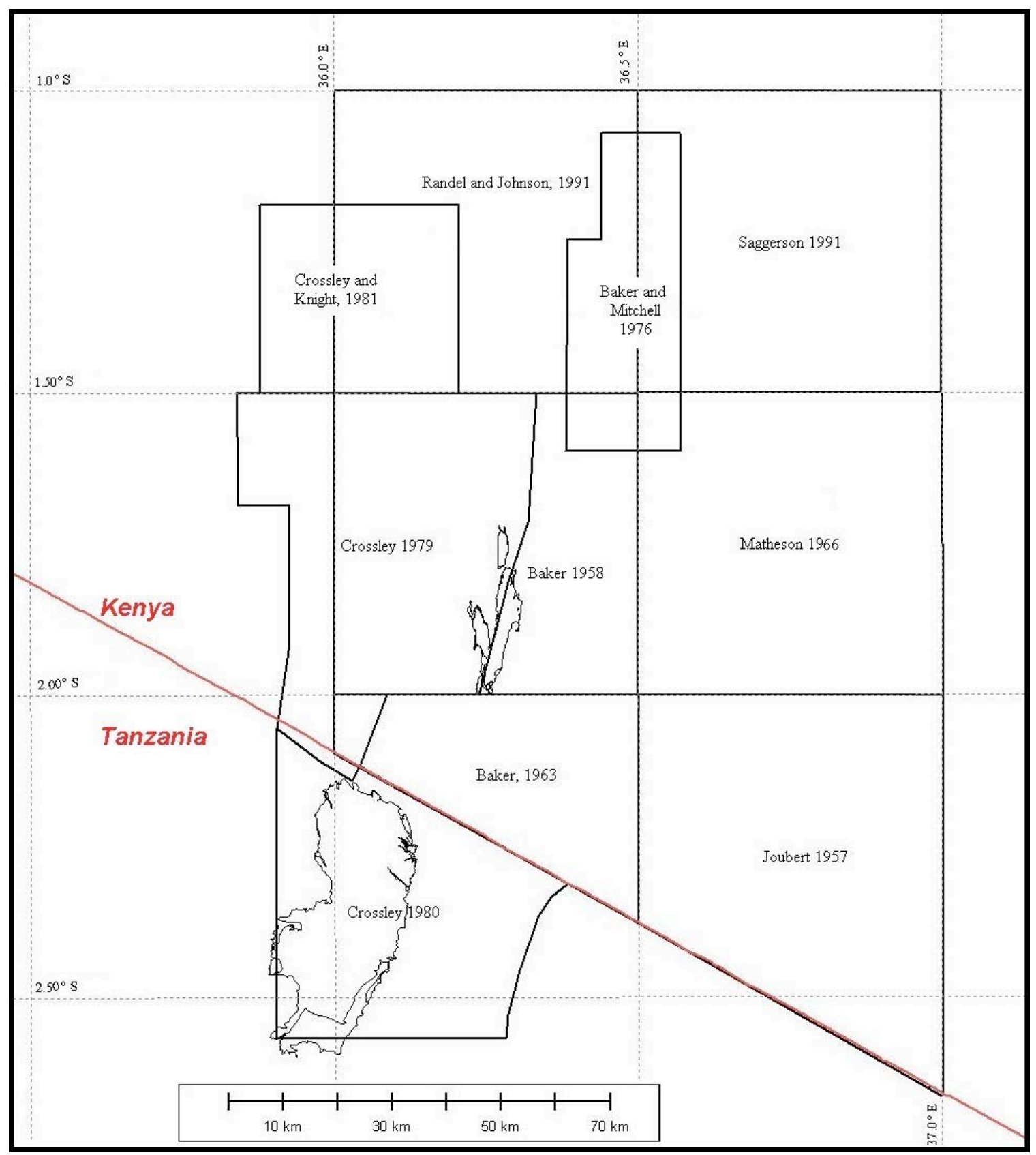

Figure 6: Plan view diagram showing location and source of geologic maps used as keys to interpreting the satellite images. Note that the larger (roughly quarter degree) maps were done by the Kenya Geologic Survey and the smaller maps which overlap them were from papers published later and provide much of the new detail seen in the maps produced for this study. Also note that while the publication year for Randel and Johnson and Saggerson is 1991, the mapping was done in the 1960's, therefore the overlapping maps from 1976 and 1981 reflect more recent geologic information. 
A. Guth, MS Thesis, 2007

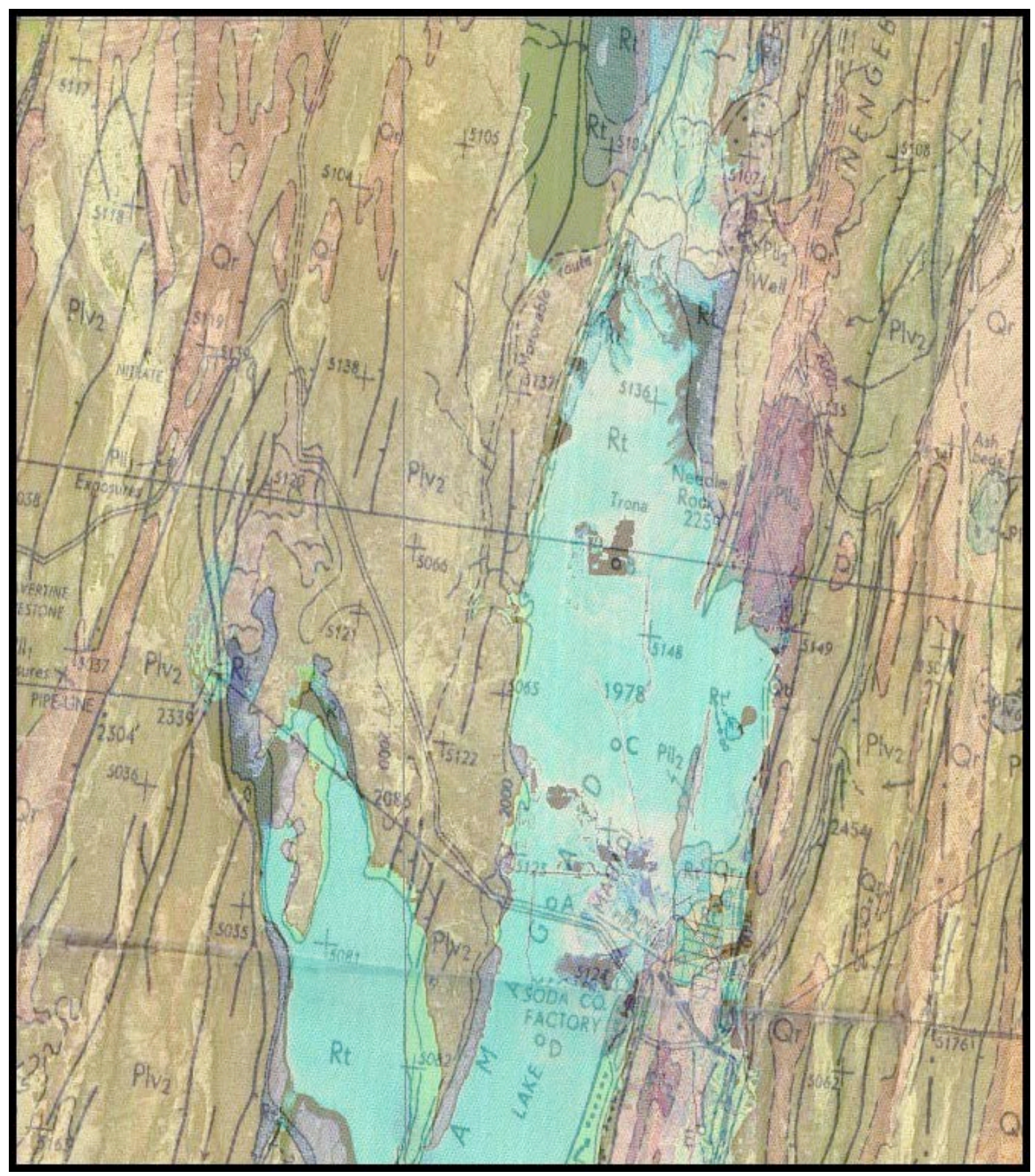

Figure 7: Geologic map of Magadi Area (Baker 1958) overlaid onto a Landsat image. The geologic map has been georeferenced using the stated corner coordinates. This unedited mosaic shows a distinct offset between the coordinates of the geologic map and the Landsat image. 
A. Guth, MS Thesis, 2007

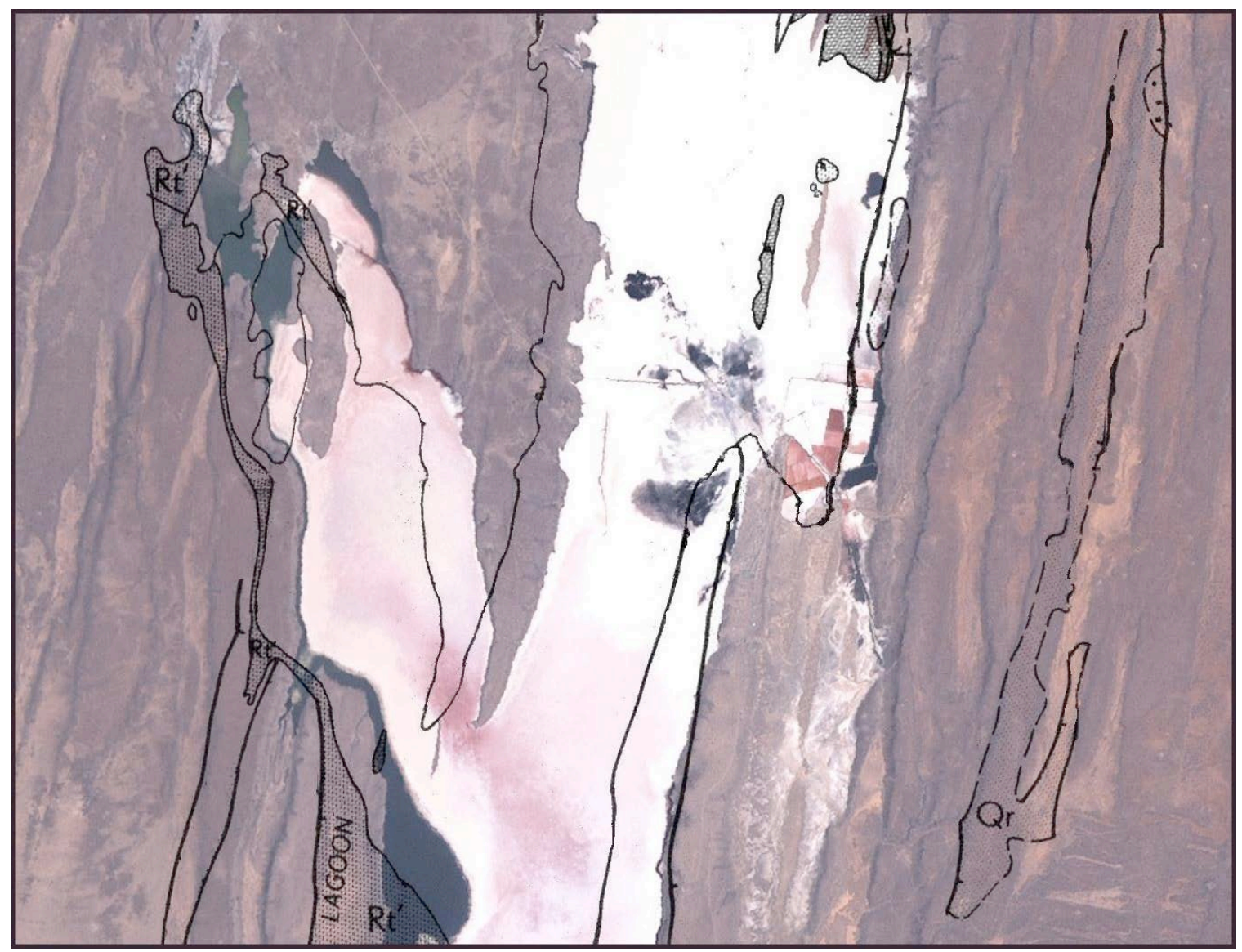

Figure 8: Mosaic of central portion of Lake Magadi using geologic map (Baker 1958), which has been simplified to a line drawing, and Landsat image (bands 1,2,3). Coordinate offset between the geologic map (black lines) and the Landsat image is clearly evident. Offsets range from $590-800 \mathrm{~m}$ and displacement azimuths vary between $70-122^{\circ}$. 
A. Guth, MS Thesis, 2007
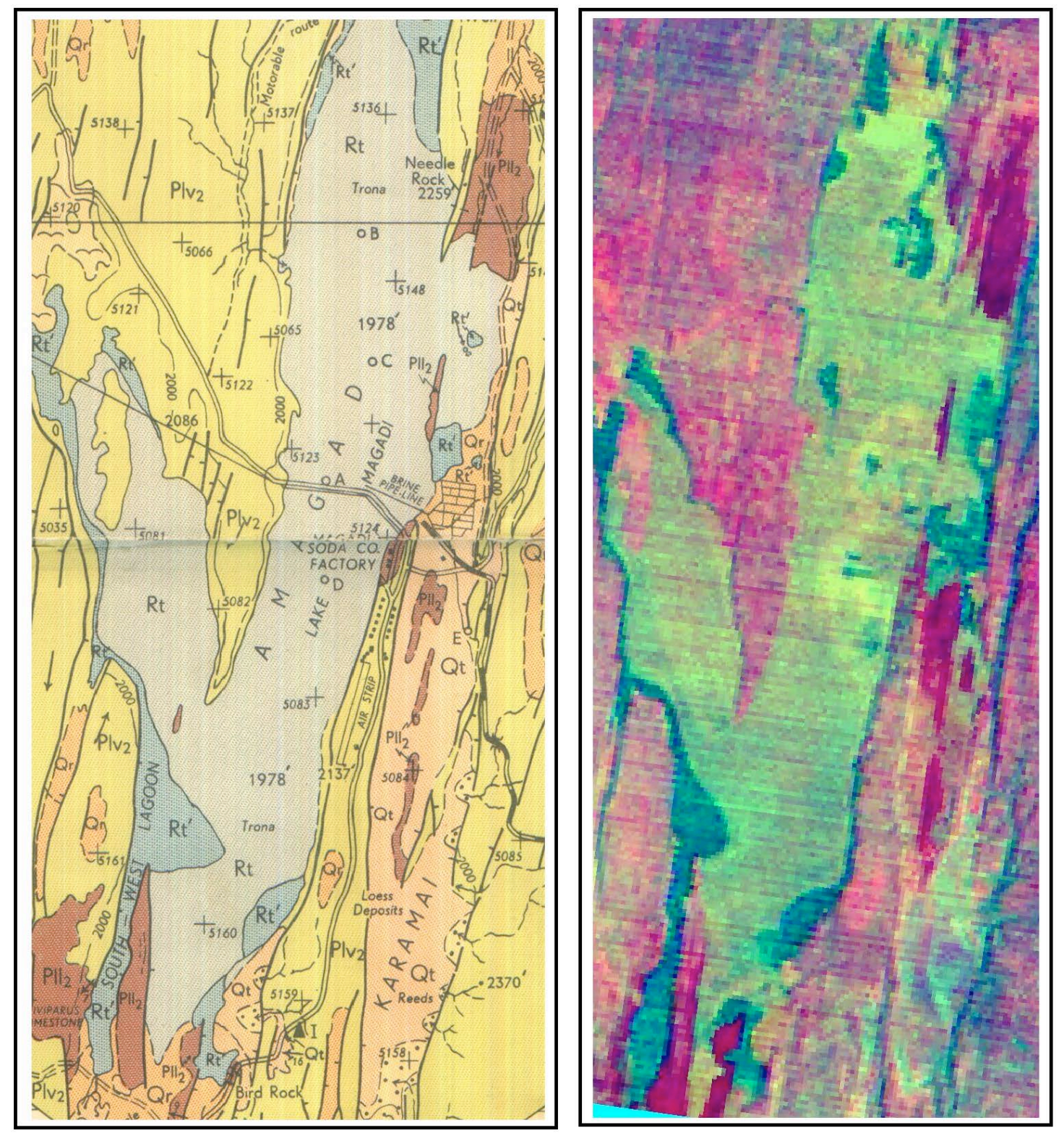

Figure 9: Geologic map (from Baker 1958, left) and Principal Components (PC) image (right) of the Lake Magadi area. The PC image was created from a 2005 ASTER satellite image using the thermal bands. The Chert Series (Green Beds) are shown in red on the geologic map and matching areas can be seen as dark magenta in the PC image. 


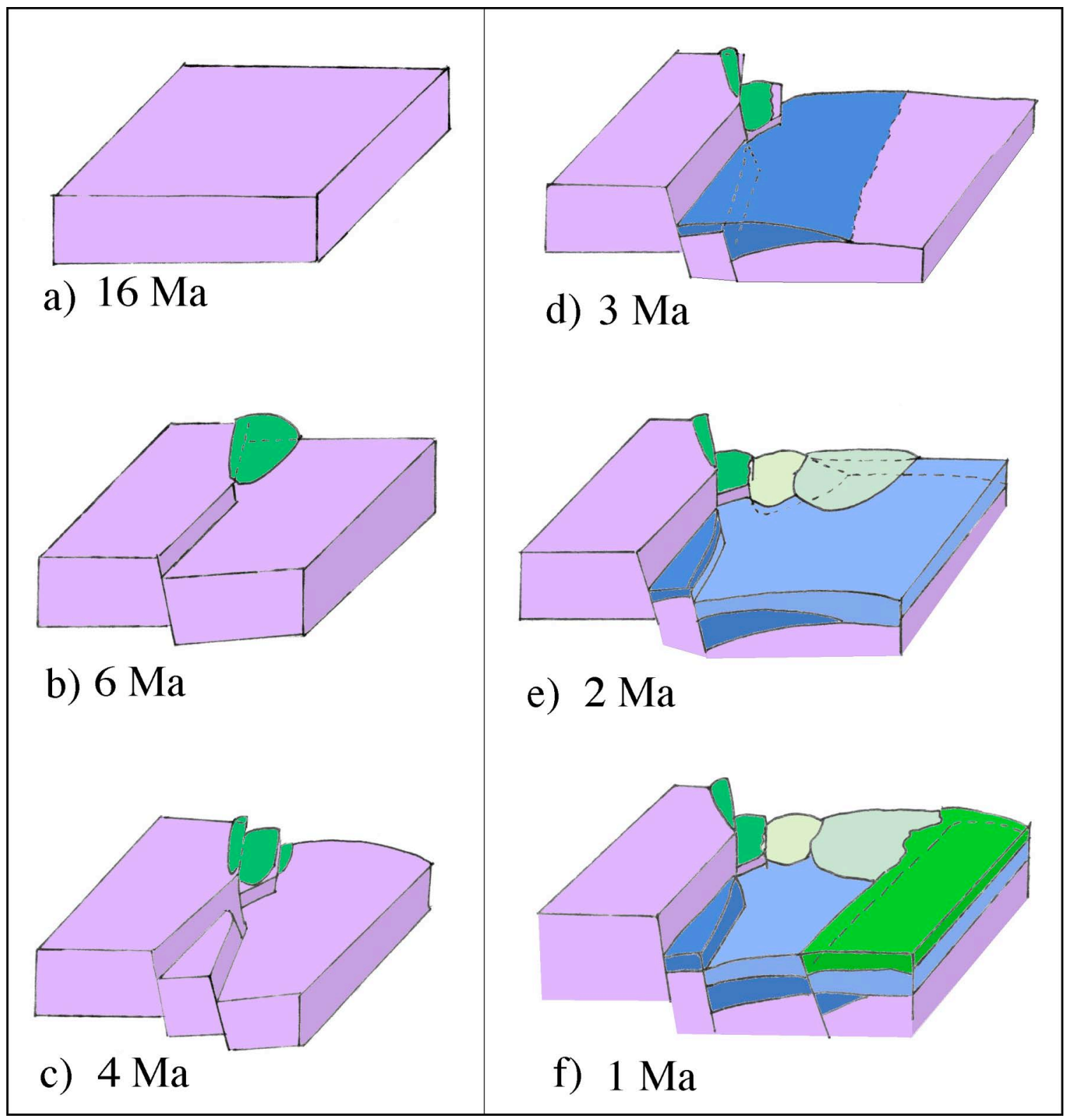

Figure 10: Diagram illustrating the evolution of the northwest section of the Magadi map area, based on events outlined in Crossley, 1979. Images from top to bottom, left to right, show the progression from $16 \mathrm{Ma}$ to $1 \mathrm{Ma}$. The final image shows a complex relationship between a variety of volcanic formations, but this can be arrived at through a series of relatively simple steps. For example, a fault cuts basement rocks and lava is erupted into the graben and overtops the escarpment (b). Renewed faulting breaks up the volcanic flow (c) with the down dropped part buried by more recent volcanism (d). These simple processes lead to the situation where one unit is seen at various elevations and is only covered by younger flows in certain locations. 


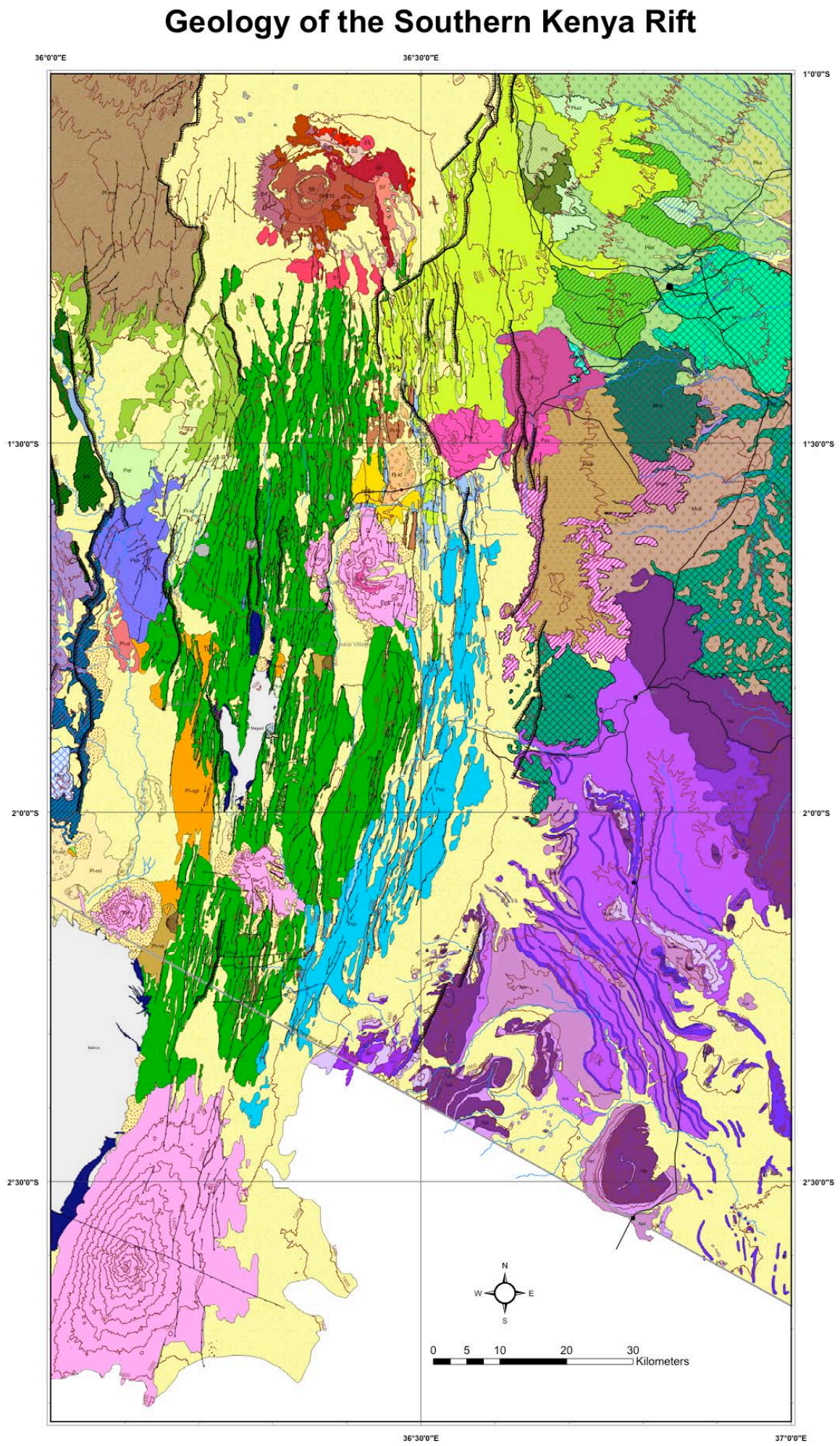

Figure 11: Completed geologic map of the Southern Kenya Rift. This map extends from $1.5^{\circ} \mathrm{S}$ to the Tanzania border with the exception of a small area (southwest corner of map) that extends into Tanzania. Map covers the following KGS map areas: Suswa, Nairobi, Magadi, Kajiado, South Magadi and Namanga. 

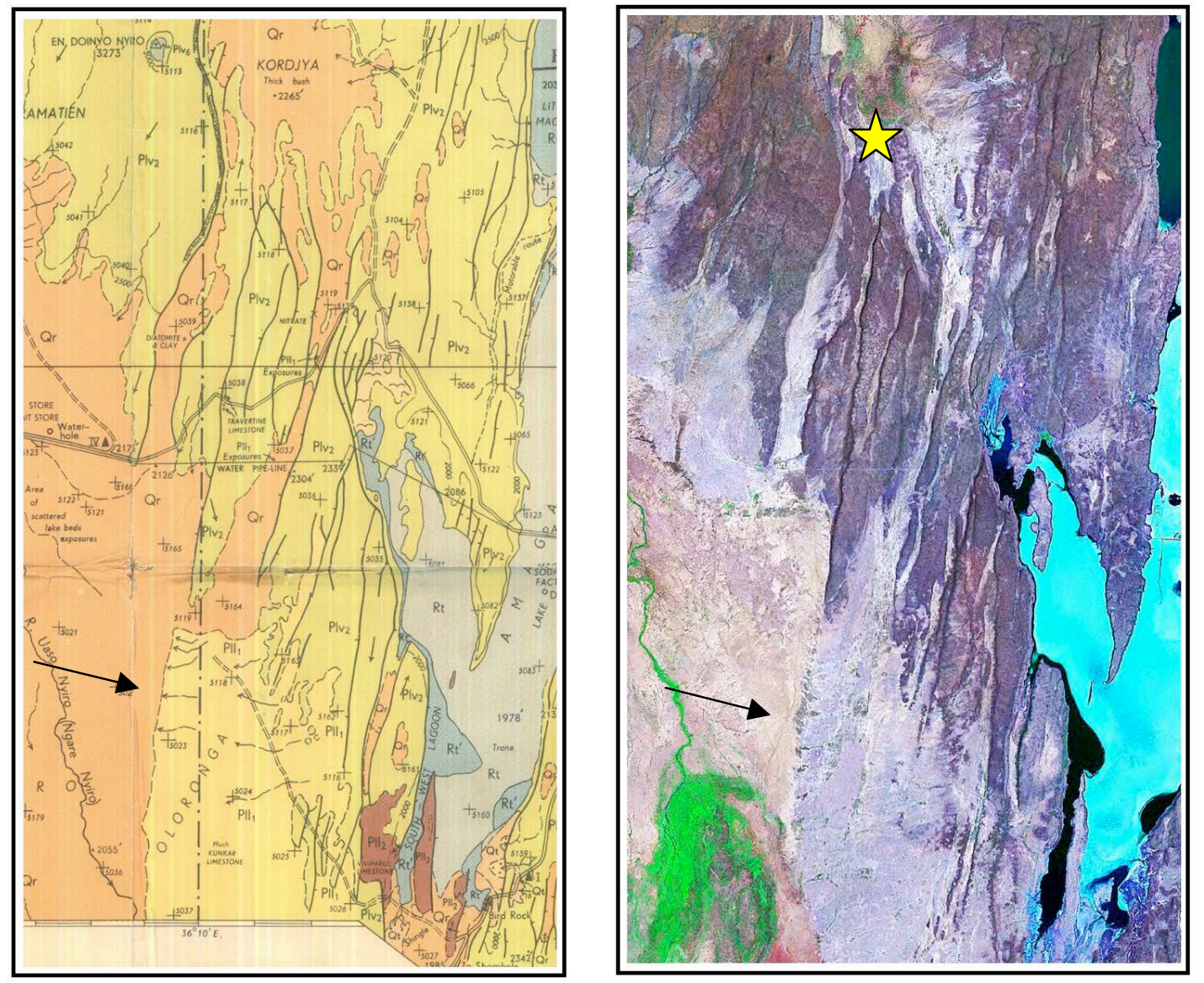

Figure 12: Comparison between Baker's 1958 Geological map (left) and Landsat image (right). The Oloronga lake beds are shown in yellow near the bottom of the geologic map (see arrow). In the Landsat image the Oloronga beds are easily distinguished from the Quaternary sediments by their light purple color (see arrow). For the geologic map produced in this study, the boundaries seen in the Landsat image were given preference over the 1958 map, which is confirmed by mapping done by Crossley (1979), and reports by Potts et al. (1988) and Shipman et al. (1983) that place the Lainyamok hominid site (represented by the star) within the Oloronga Beds. 


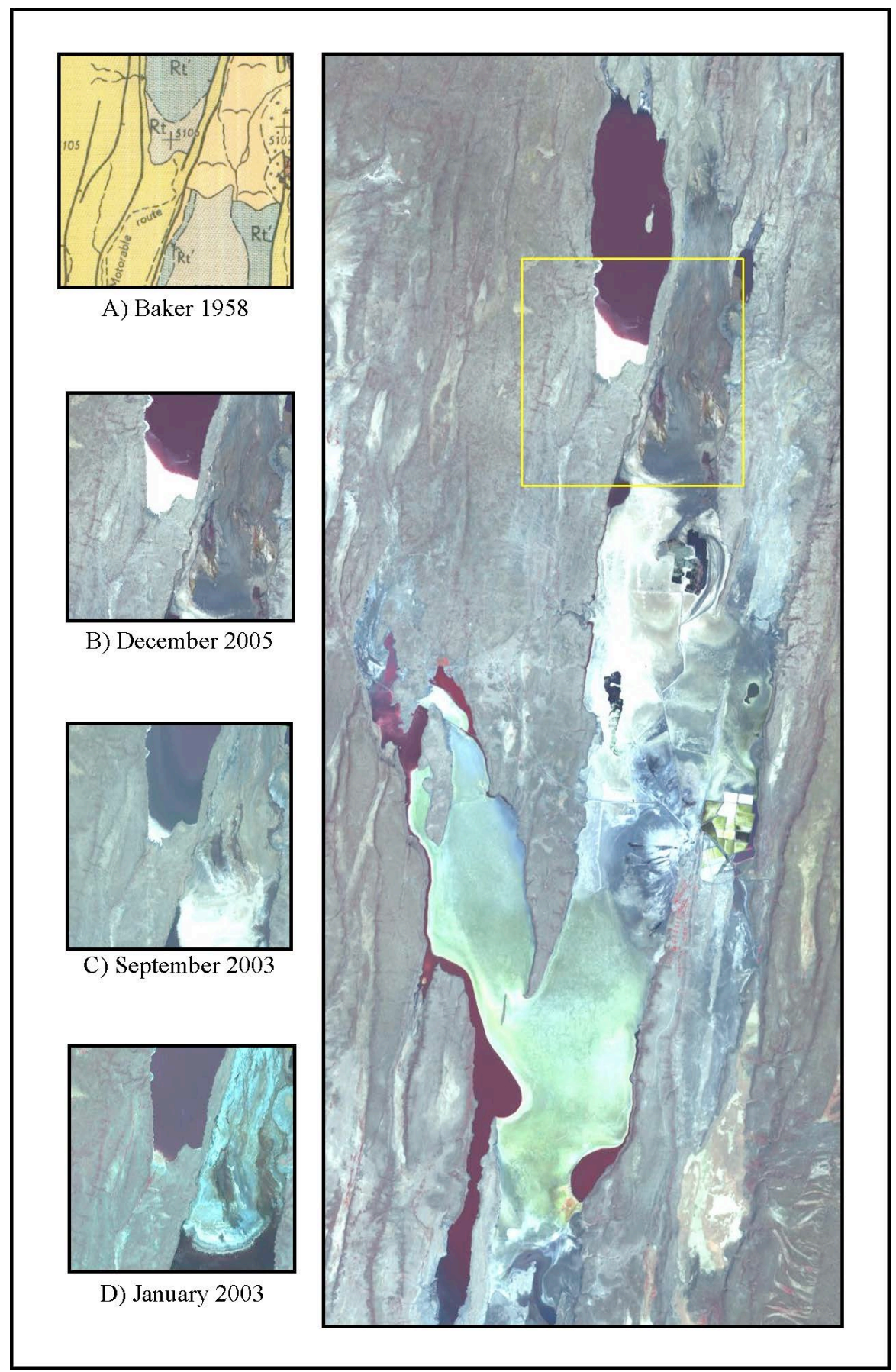

Figure 13: Comparison of exposed trona in the southern end of Little Magadi. Image on the right is a December 2005 ASTER image with the yellow box showing the area of interest as seen during different years on the left. A: Baker's 1958 Geologic Map B: December 2005, a known dry year. Note the large exposure of trona (bright white), which is probably exposed due to lower water levels. C, D: 2003 was a more normal year in terms of precipitation and the exposed trona is significantly less than in B. This clearly shows that the amount of trona exposed is the result of a dynamic system and will vary year to year. 


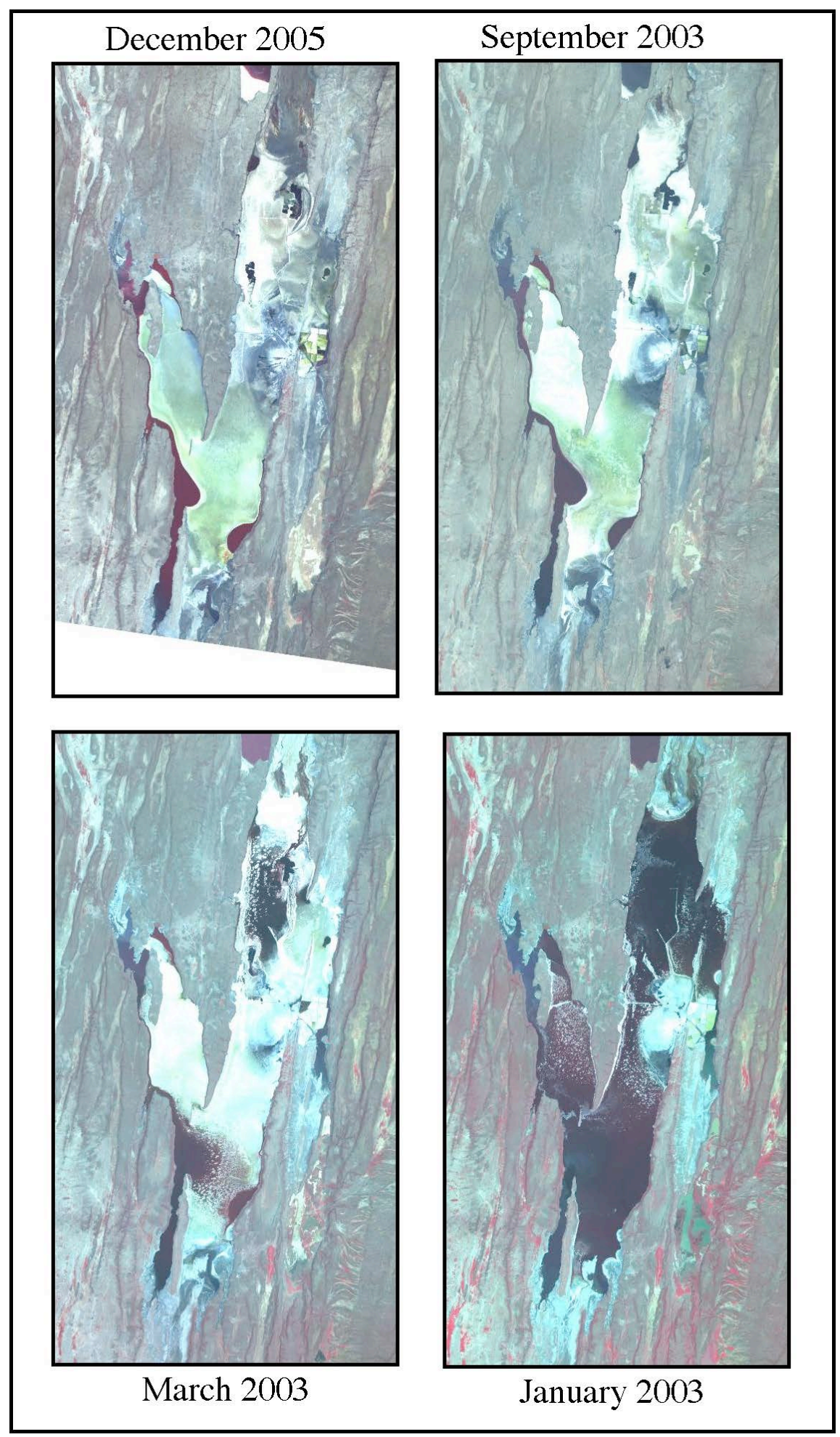

Figure 14: Lake Magadi through the seasons, with the upper left image from 2005. The light blue/white color is trona while black areas are water. During the rainy season 1-3m of water submerges the trona surface which is then exposed again as the water evaporates. 
A. Guth, MS Thesis, 2007

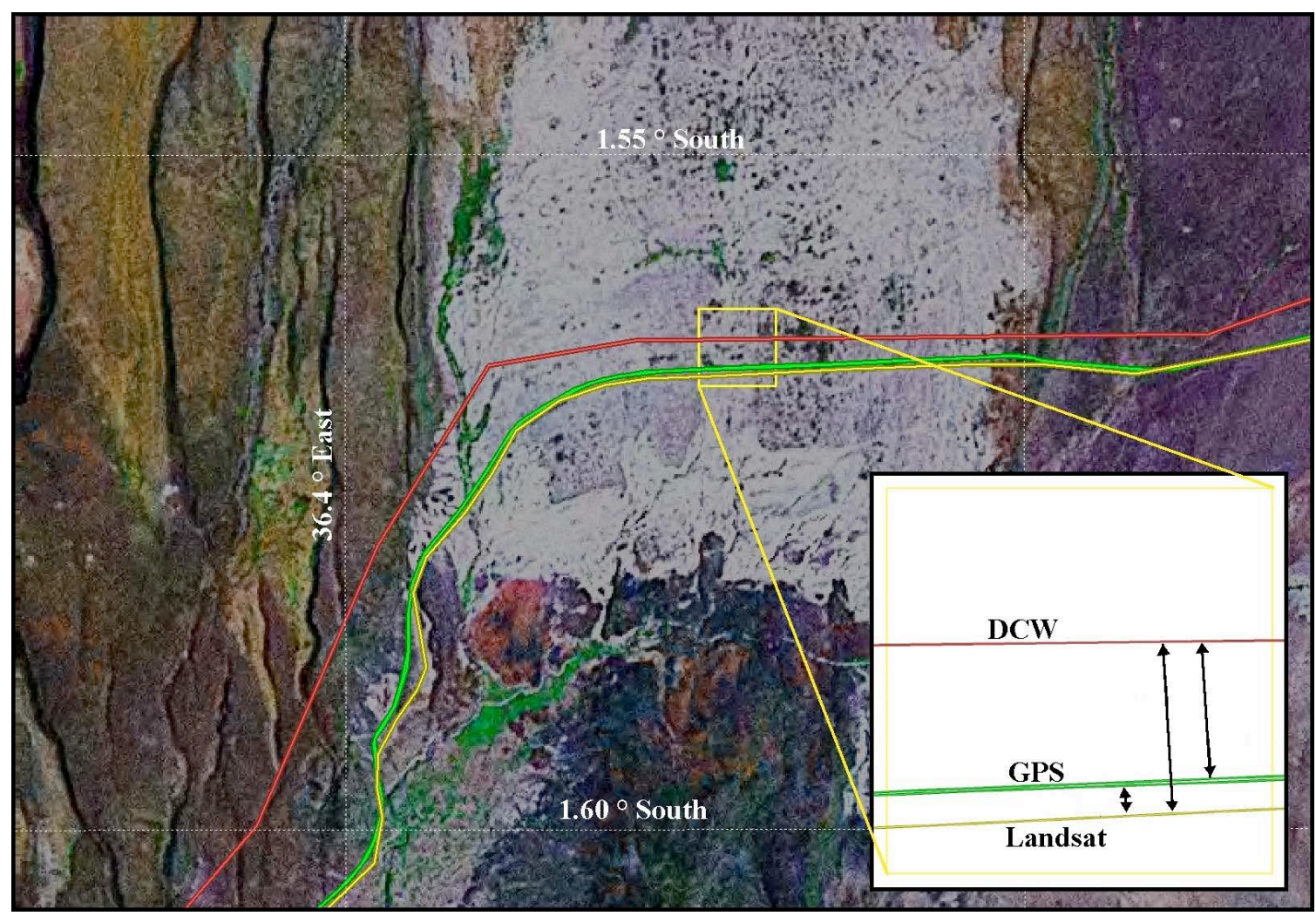

Figure 15: Landsat image of the northern Olorgesailie area showing three different road traces that are meant to represent the same road. The red line is from Digital Chart of the World (DCW), the green line is GPS data collected during the 2006 field season, and the yellow line represents the road as seen on the Landsat data. The offsets were measured at four locations within the zoomed area, perpendicularly to the three traces, and the averages are as follows:

DCW-Landsat: $\quad 287 \mathrm{~m}$

DCW-GPS: $\quad 235 \mathrm{~m}$

GPS-Landsat: $\quad 54 \mathrm{~m}$ 
Figures 16-21

Paleo-Geology Maps for 10Ma - 100ka

Figure 16: 10 Ma Paleomap. The first volcanism in this area was likely the Kishalduga and Lisudwa melanephelinites (light blue) which were erupted as early as 15.2 Ma near what would become the western rift boundary. By 10 Ma the area of the Southern Kenya rift was flooded by Plateau Phonolites (green), of which only the southern-most limit enters the study area. Graphs on the right show composition of volcanics (upper right) and volume (lower right). Composition plot shows total alkali versus silica with the units erupted before 10Ma shown in color. The volume plot shows volume based on measured area (taken from the geologic map shown in Figure 10), volume based on estimated area (area of total estimated extent, or area shown in paleomap) and cumulative volume. The cumulative volume excludes the Plateau Phonolites shown on this paleomap as the $\mathbf{3}$ different shades of green.

Figure 17: 6 Ma paleomap. The initial fault movements to define the western rift boundary occurred before $7 \mathrm{Ma}$. These movements downthrew much of the Kishalduga formation and the Lengitoto trachytes were erupted into the newly formed half graben. Some rocks from the OI Esayeti complex to the east have also been dated to this time period suggesting that it may have begun building during this time.

Figure 18: 3 Ma paleomap. More than 3 million years after the initial movements that defined the western rift boundary, corresponding movements occur to the east. There are additional fault movements along the western boundary during this time as well. Phonolites and Phonolitic-nephelinites seen on the east rift should are thought to be related to Olorgesailie, so the volcano was likely building at this time. The Ngong hills are also thought to have developed in this period. The Kirikiti basalts erupted against the western boundary faults and extend to the present location of Sambu in the South. The Nairobi trachytes in the north were probably erupted within the rift and overflowed onto the rift shoulders. 
Figure 19: 2 Ma paleomap. A number of volcanoes developed between 3 and 2 Ma including Sambu, Shombole, Lenderut, and Gelai in addition to further eruptions from Olorgesailie. Some small trachyte eruptions occurred on the eastern shoulder as well as the eruption of the Kerichwa Tuffs. Within the rift the Singaraini basalts were erupted along the eastern side and the Kordjya basalts were erupted in the area northwest of present-day Lake Magadi. The Mosiro and Ewaso Ngiro trachytes were also erupted onto the rift floor at this time.

Figure 20: 1.5 Ma paleomap. Between the eruption of the Mosiro trachytes around 2.3 Ma and the Limuru trachytes at 1.9 Ma, much of the northern study area was likely covered by trachyte flows. The Limuru trachytes also overflowed the eastern fault scarps and flowed onto the rift shoulders. There were some smaller, more localized eruptions of Pantellerites and Benmoreites during this period. The oldest lake beds in the study area are in the Lake Natron basin and are about $1.5 \mathrm{Ma}$ indicating the presence of a paleolake at this time.

Figure 21: 100 ka paleomap. The center of the rift floor was flooded by the Magadi (a.k.a. Plateau) trachytes which were probably erupted from fissures. The oldest flows in this eruptive series are 1.4 Ma with activity continuing until around 780ka. A number of small cones (both trachytic and basaltic) were formed around 600ka and the Mau ashes in the northwest were erupted around the same time. The rift floor was broken by a number of small faults that have been dated to around $400 \mathrm{ka}$. Suswa, a shield volcano in the north of the study area, began erupting around 240ka. There was likely a large lake occupying the Magadi and Natron basins at this time, and a massive flood caused by the catastrophic draining of a lake in the Suswa area is thought to have occurred at this time. 
A. Guth, MS Thesis, 2007

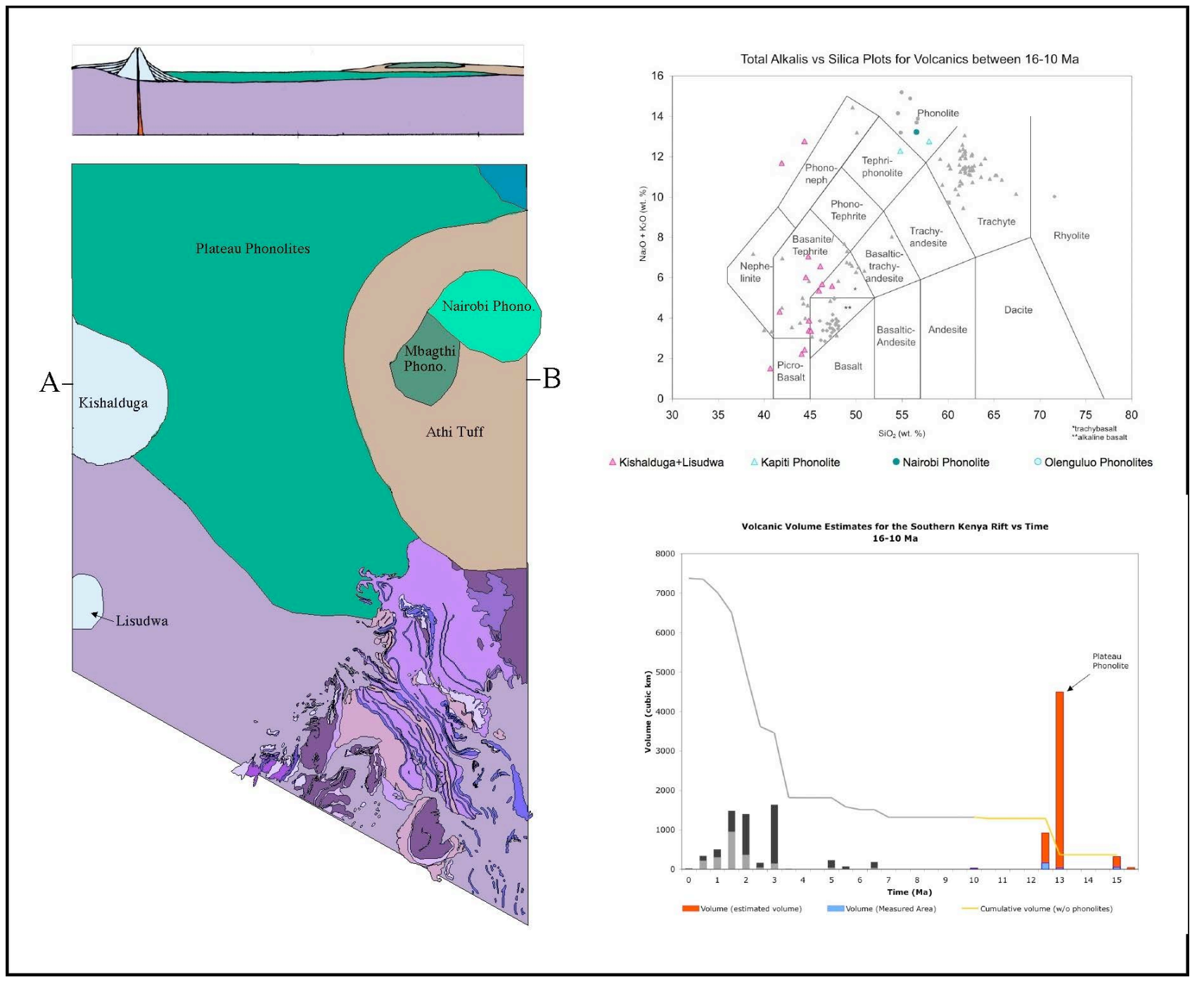

Figure 16: 10 Million Years Ago

A-18 
A. Guth, MS Thesis, 2007

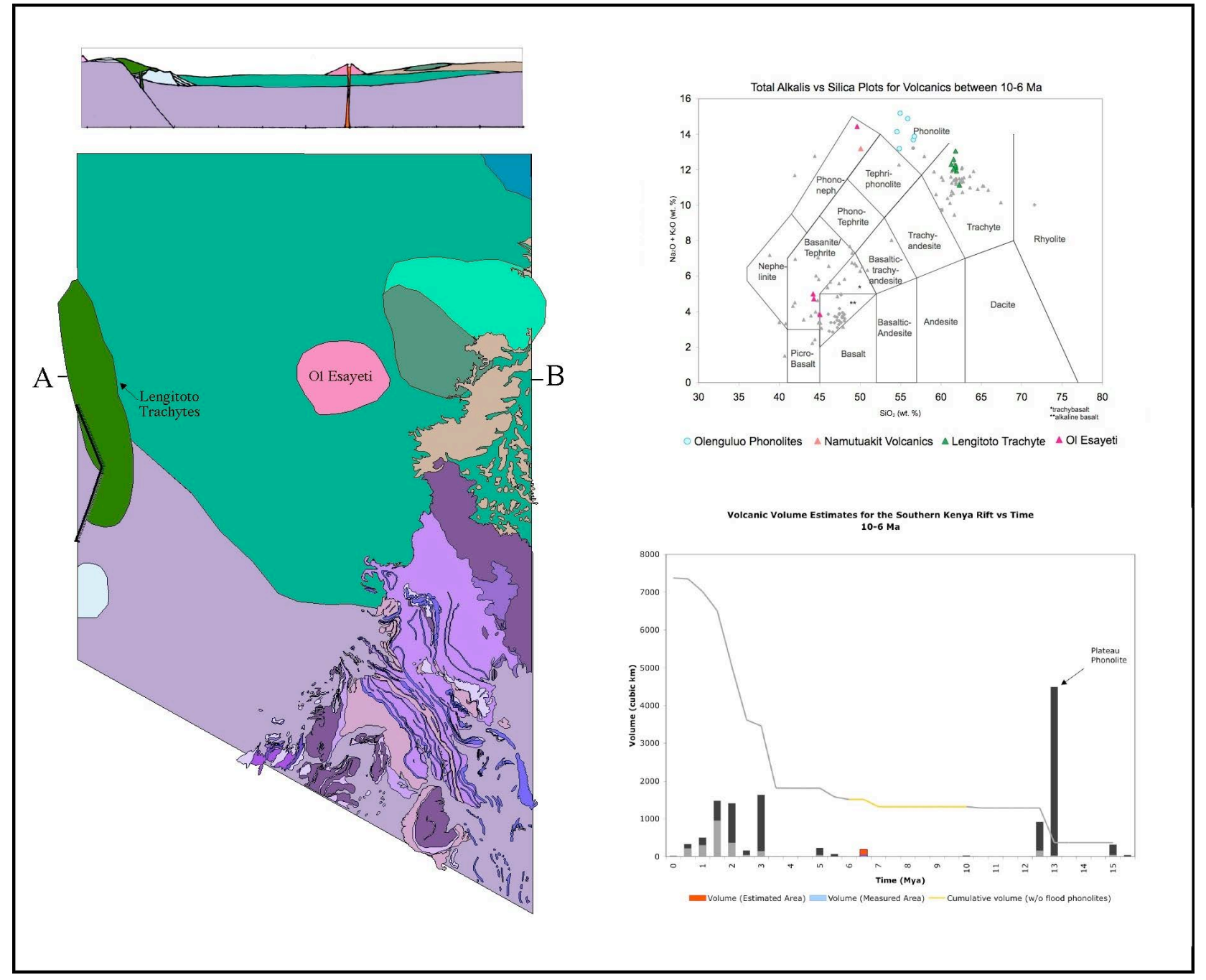

Figure 17: 6 Million Years Ago 


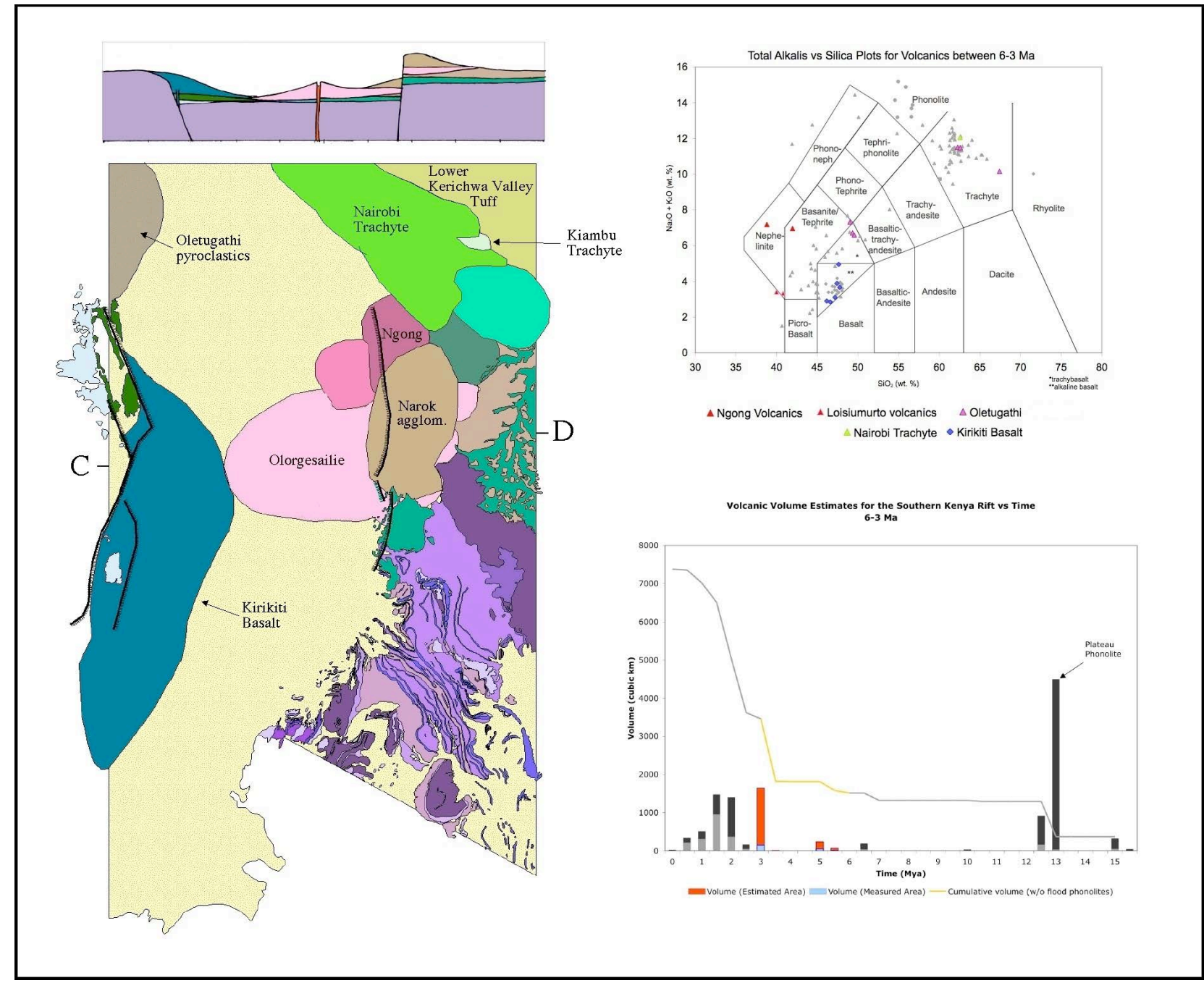

Figure 18: 3 Million Years Ago 


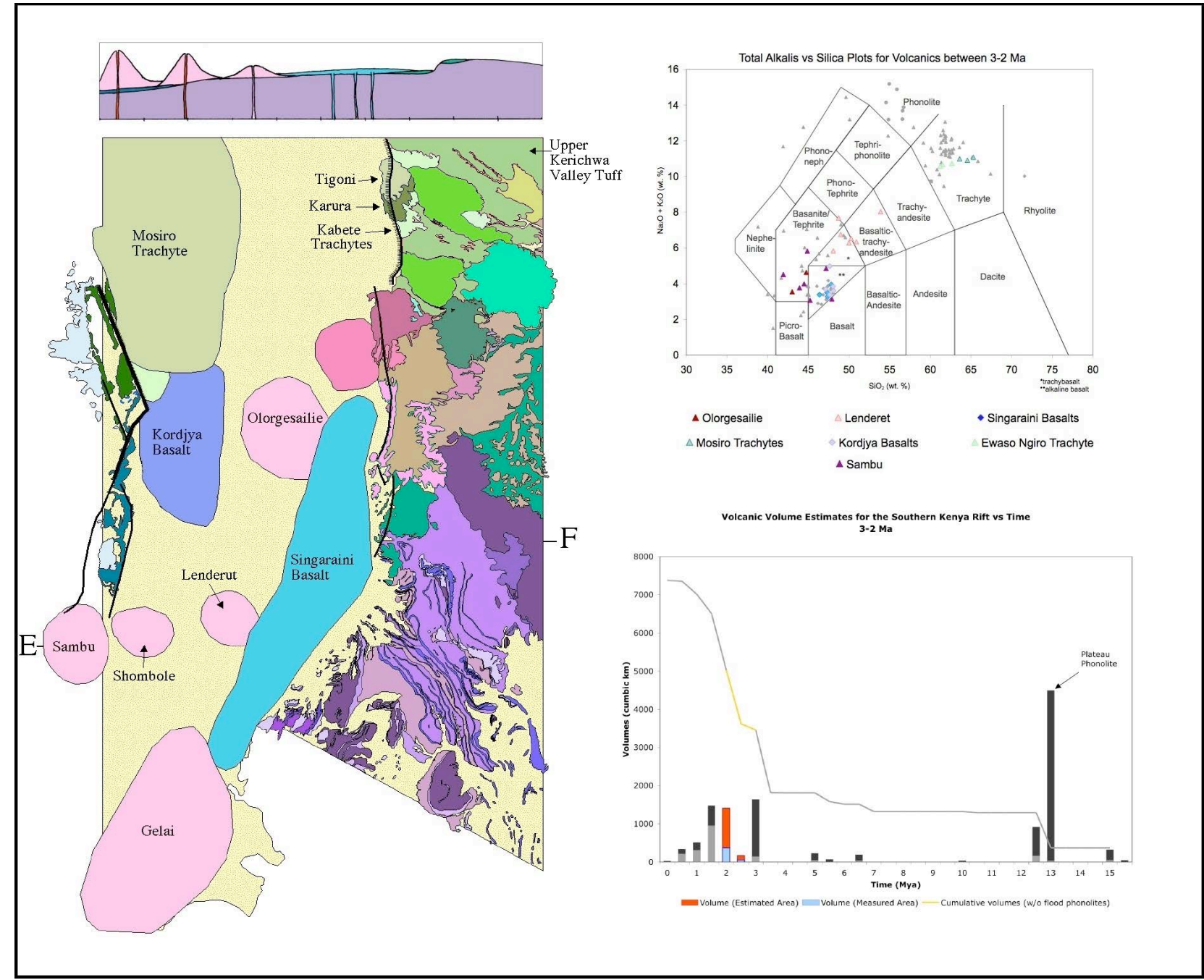

Figure 19: 2 Million Years Ago 


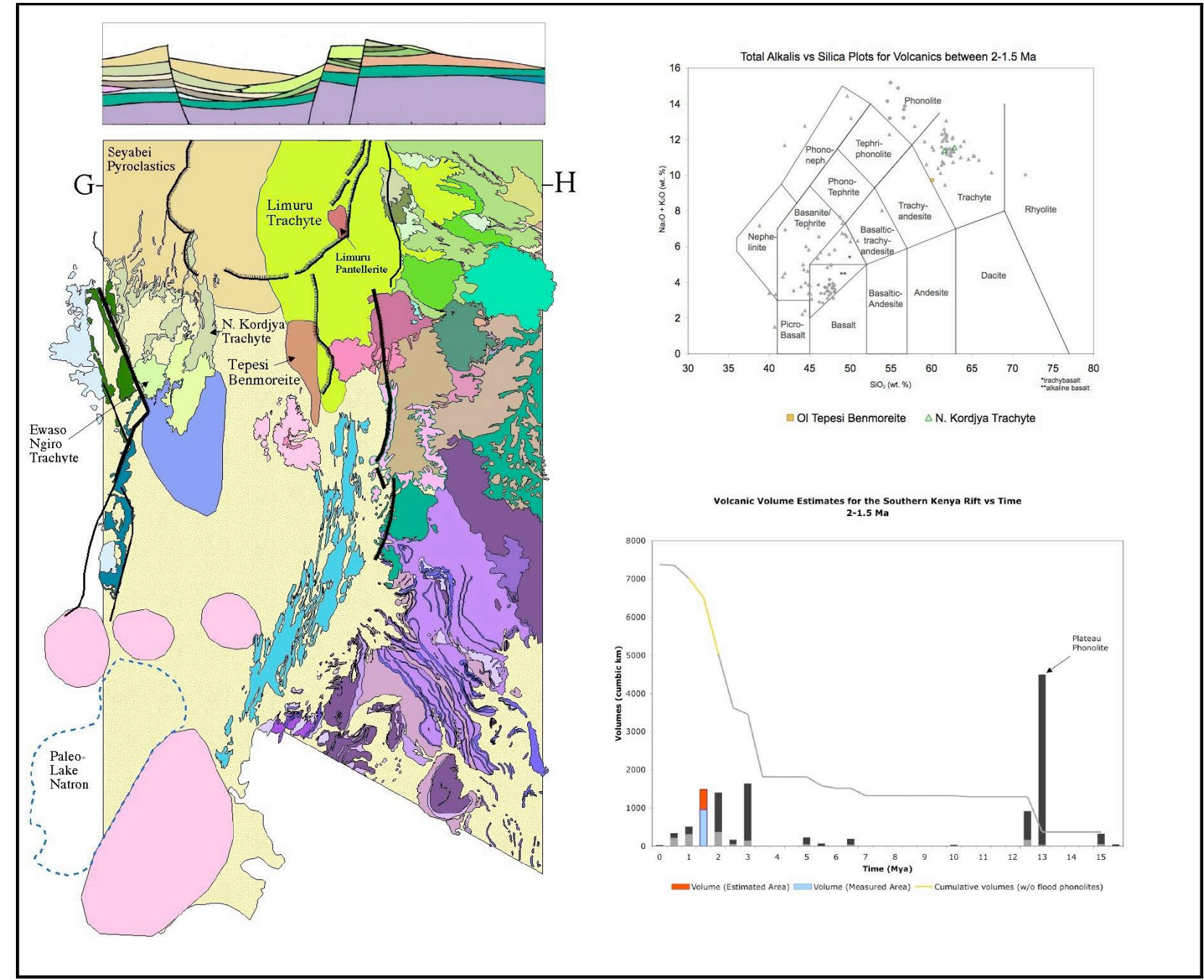

Figure 20: 1.5 Million Years Ago 
A. Guth, MS Thesis, 2007

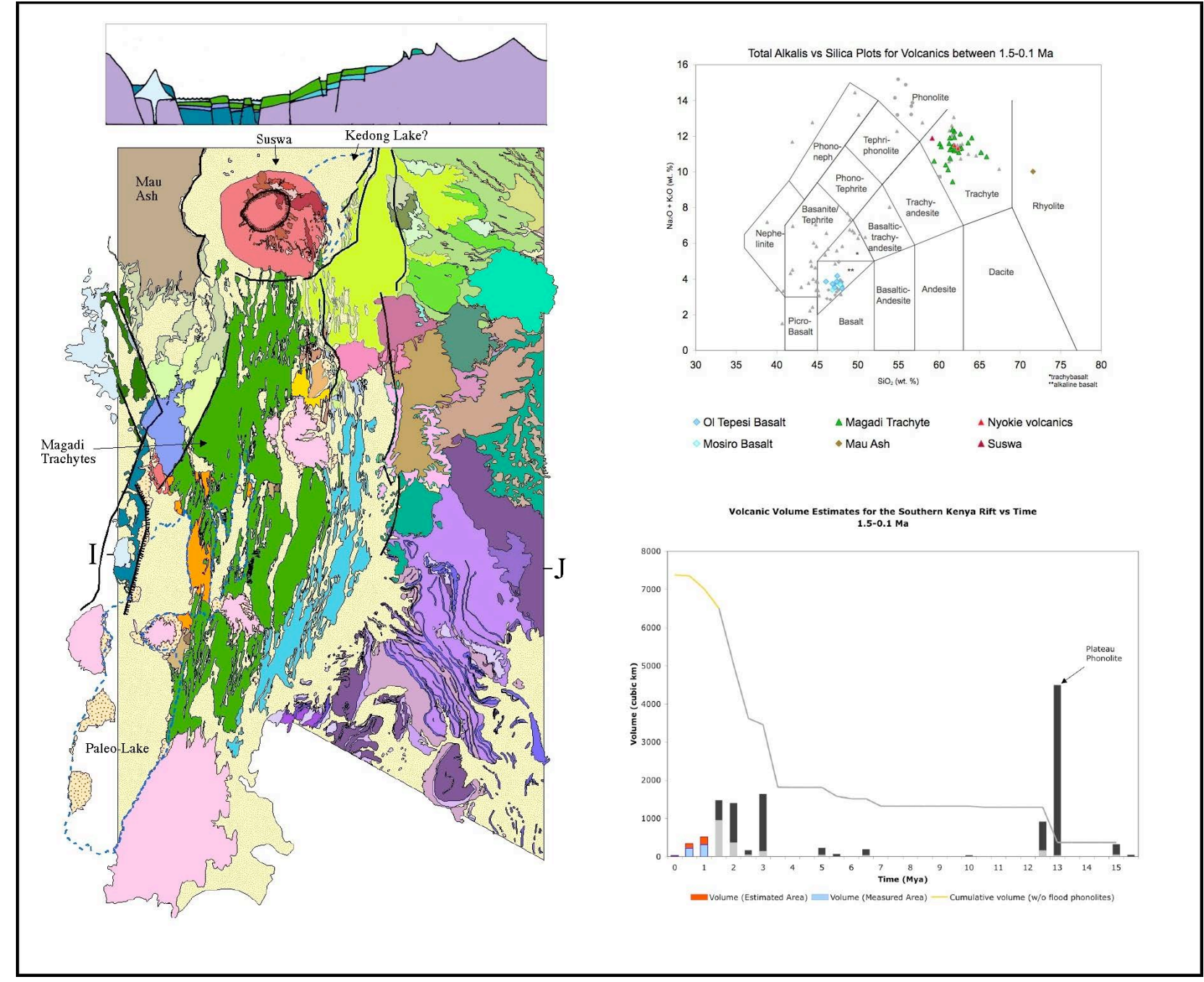

Figure 21: 100 Thousand Years Ago 
Estimated Fault Displacement in the Southern Kenya Rift vs Time

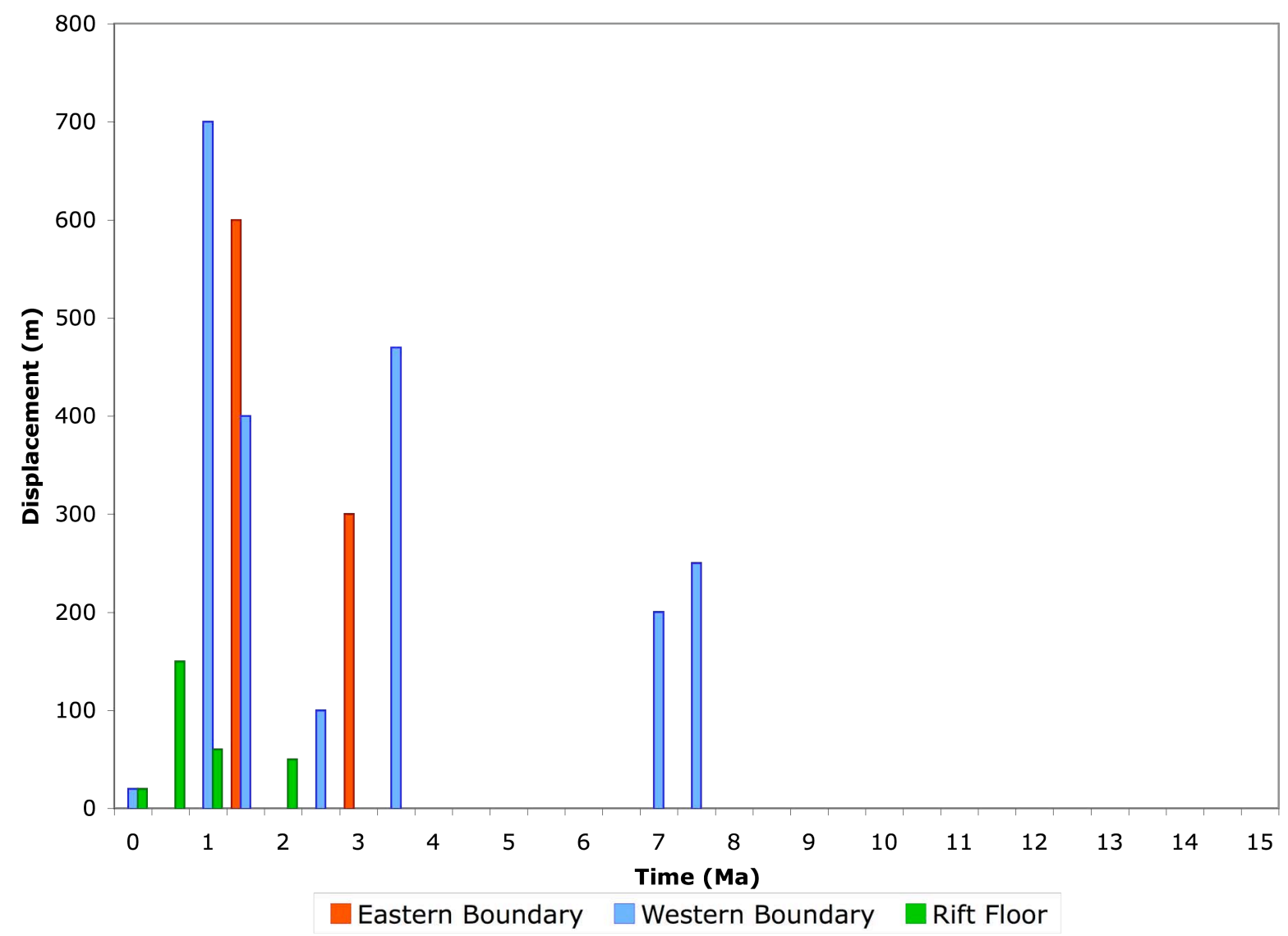

Figure 22: Graph showing estimated fault displacement over time. Blue bars represent vertical displacements in meters along the faults that define the western boundary of the rift. Red bars are the same except for eastern boundary faults and green bars represent fault displacements in the rift floor. See Table 1 in text for references for displacement estimates. 


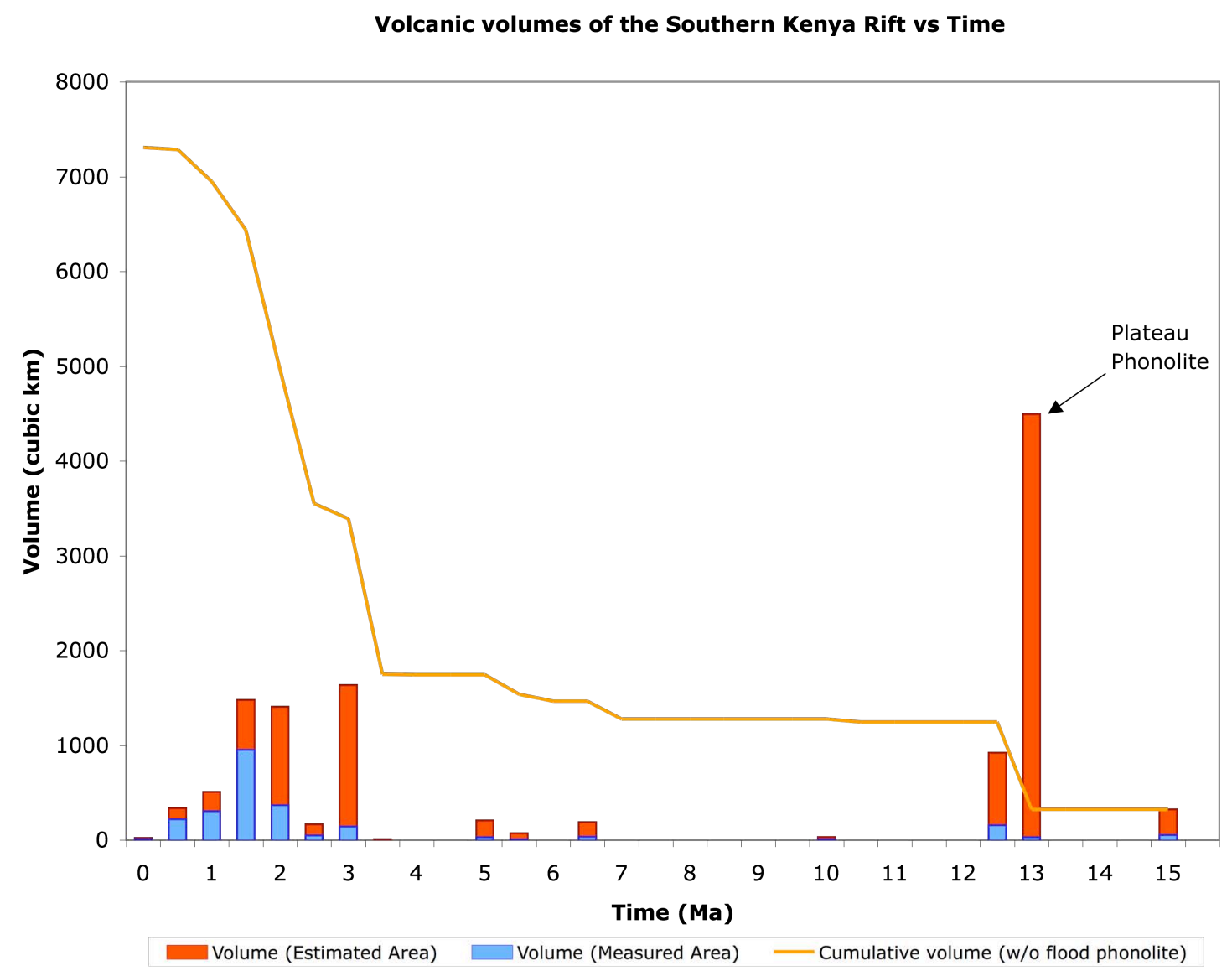

Figure 23: Volume versus time plot for the Southern Kenya Rift volcanics. The blue bars represent the volume calculated from exposed (mapped) surface area. The red bars show volume based on estimated probable extent and the Orange line represents the cumulative volume based on estimated volumes without input from the Plateau Phonolites. 
Volume contribution of different petrologic groups vs Time

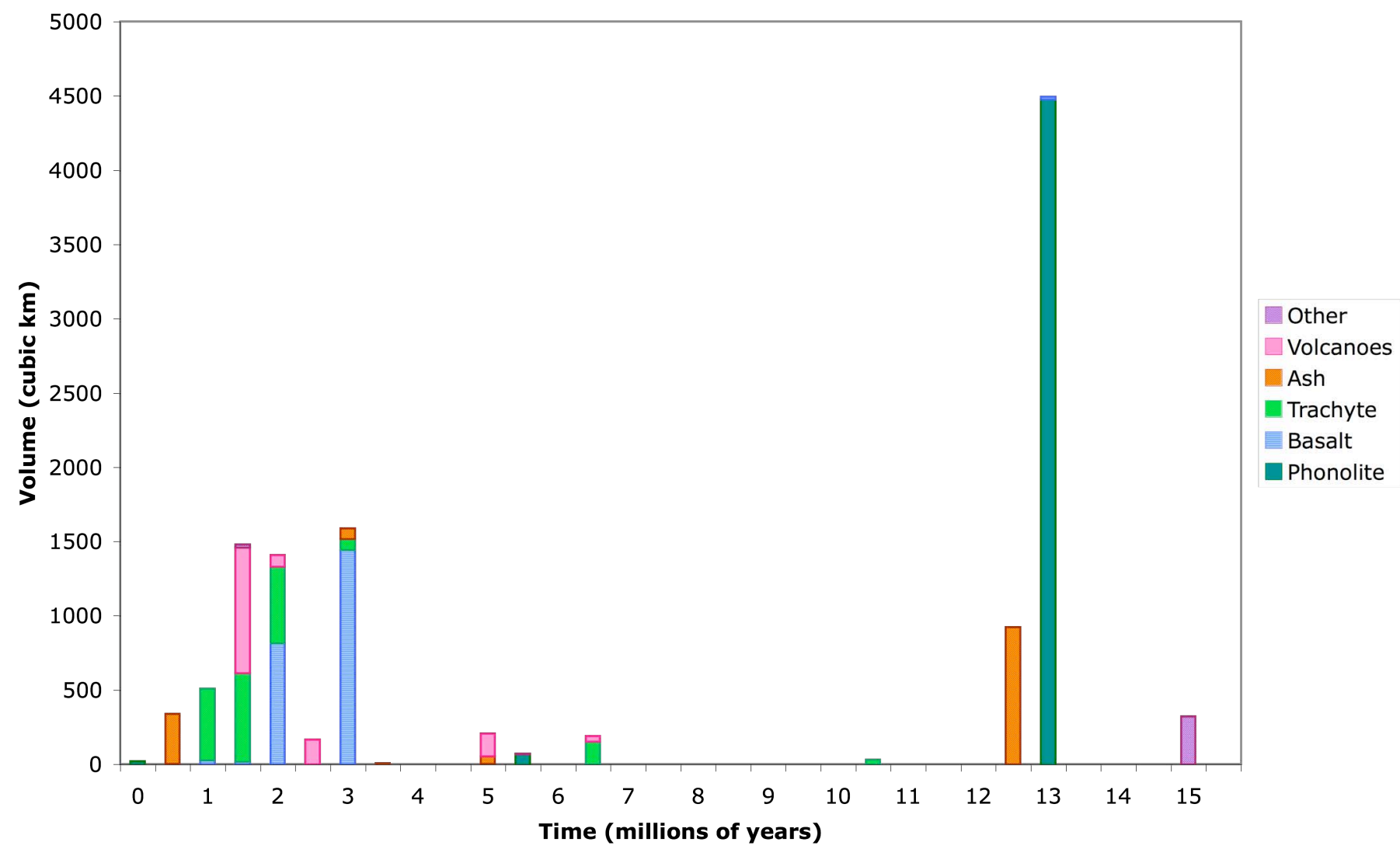

Figure 24: This plot is the estimated volume versus time as in Figure 23, except that the bars have been subdivided to show the contribution of the different types of volcanic rocks. It is clearly shown that volume of the different major volcanic rock types has not been constant over time. 


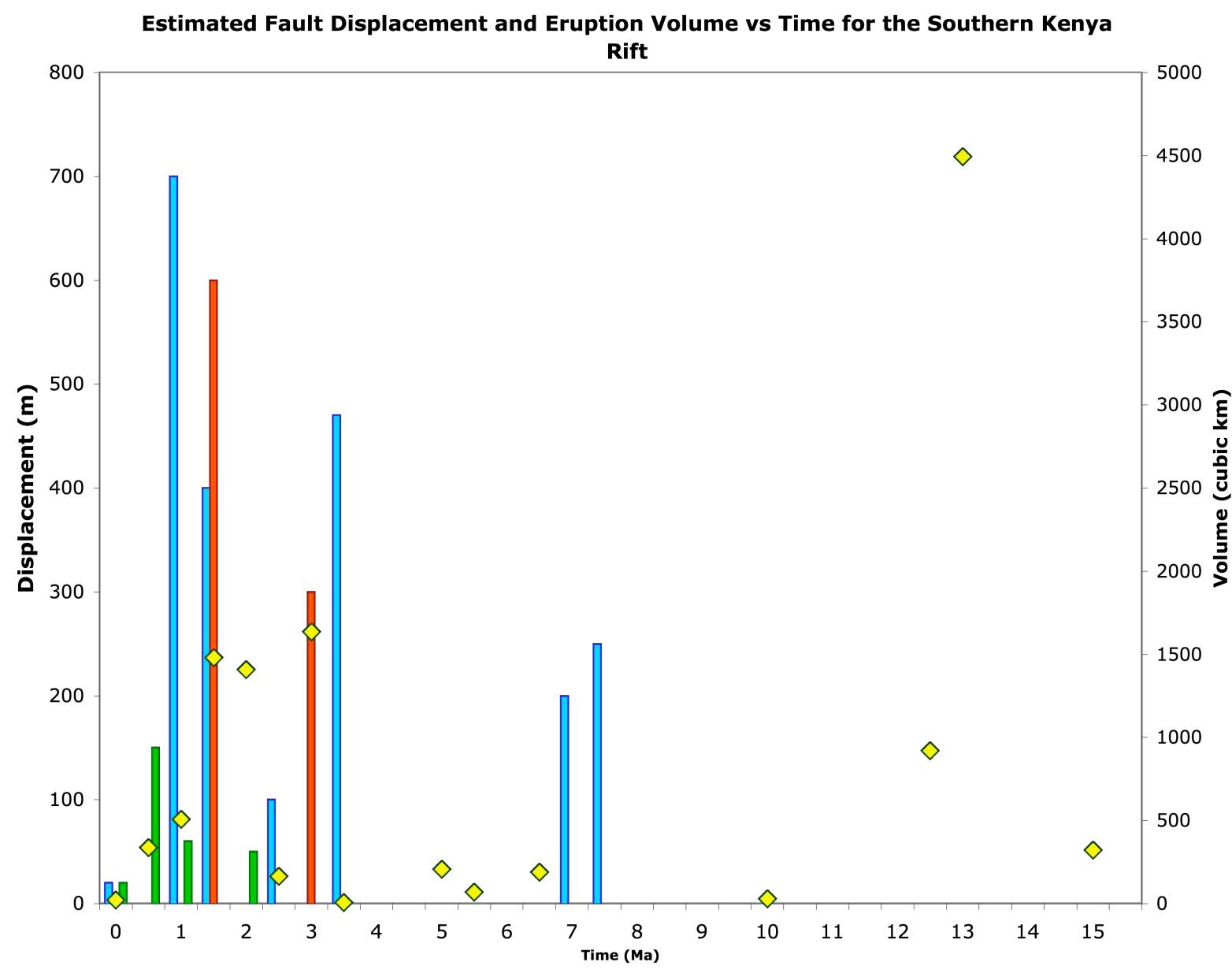

Figure 25: Graph of fault displacement and erupted volcanic volume versus time. Yellow diamonds represent erupted volume in cubic kilometers and bars represent fault displacement in meters. Bars indicate fault displacement in meters on the western boundary faults (blue), eastern boundary faults (red), and in the rift floor (green). 


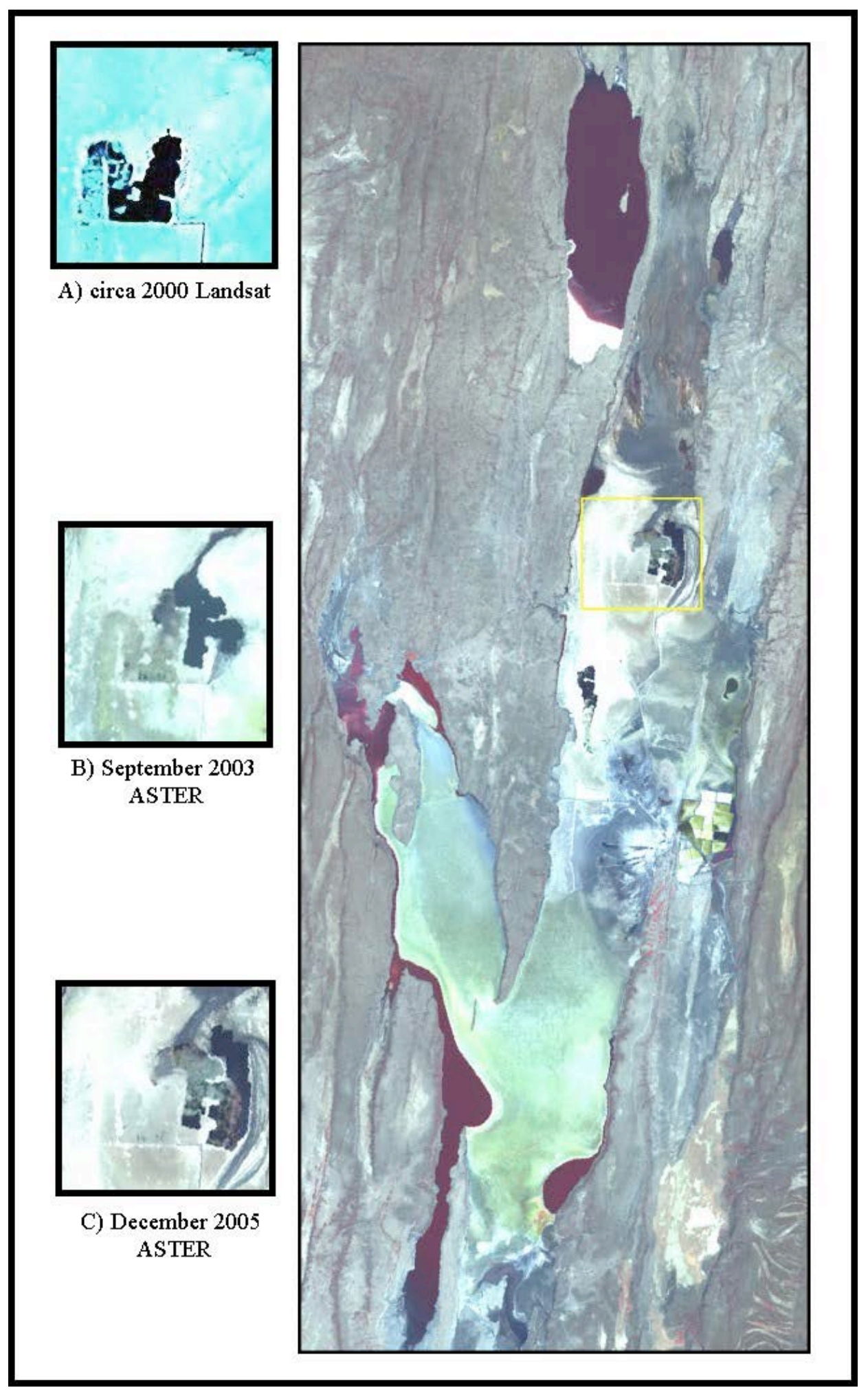

Figure 26: ASTER image of Lake Magadi (December 2005) on the right with the area of focus shown by the yellow box. Images on the left show the active mining area in 2000 (A) which was relocated sometime between 2000 and 2003, and afterwards, the previous excavation site can be seen to close up with trona. 
A. Guth, MS Thesis, 2007

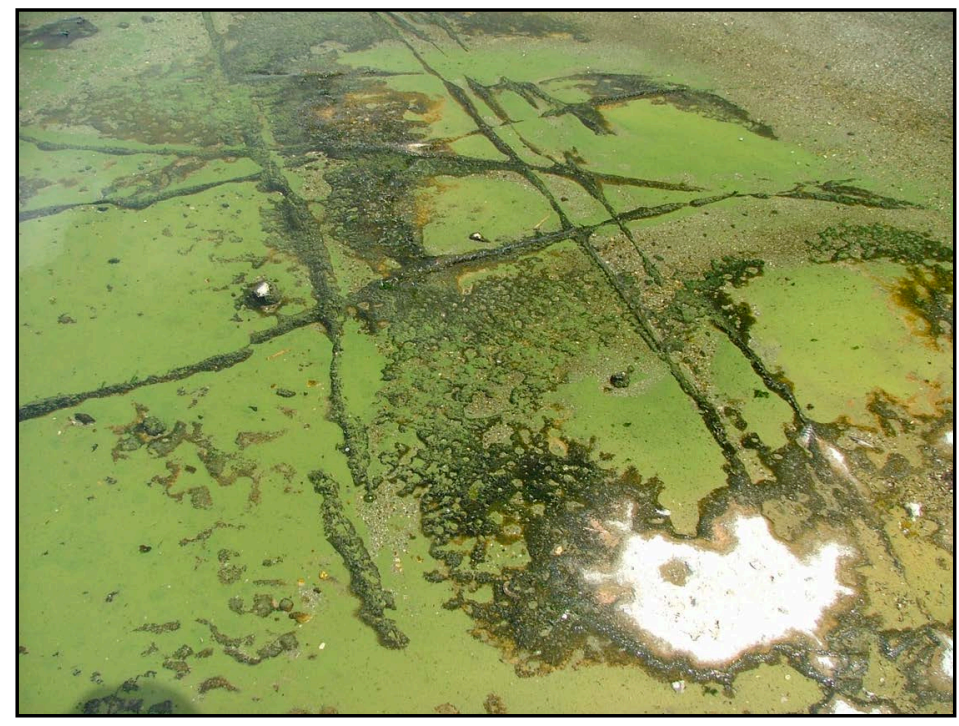

Left- A) In the field:

Sample A1 grew along linear ridges about 1-inch high that were covered by shallow water and were located away from the spring vents. The ridges are probably fractures through which waters well up and supply nutrients to the biologic communities growing on them.

Right- B) 1000x magnification: This image shows one of the infrequent diatoms (not identified) in addition to segmented filaments that comprise the bulk of the sample. At low magnification the bulk of the sample appears as a hairy green mass, probably composed of Oscillatoria (see below).
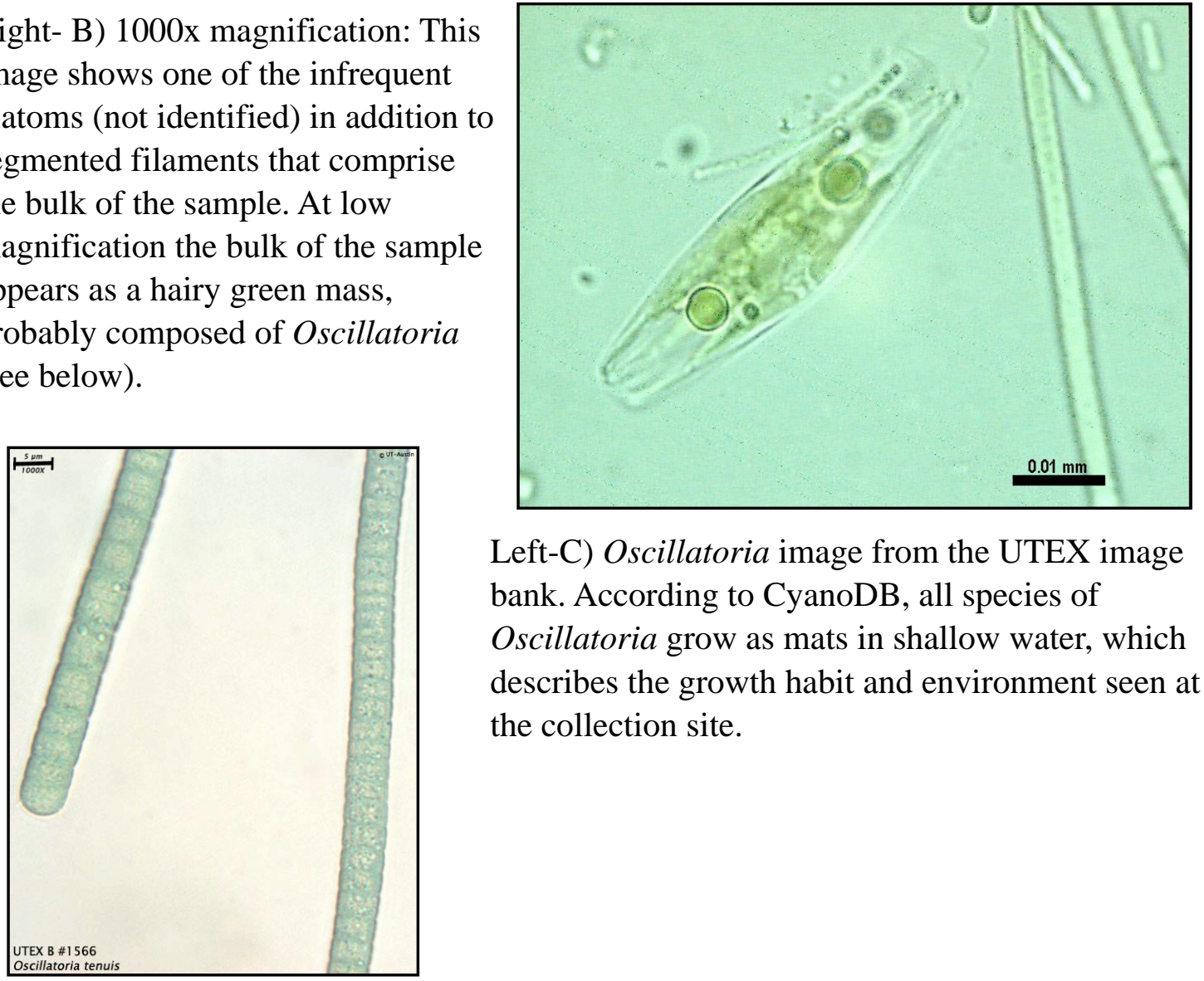

Left-C) Oscillatoria image from the UTEX image bank. According to CyanoDB, all species of Oscillatoria grow as mats in shallow water, which describes the growth habit and environment seen at the collection site.

Figure 27: Images of biologic sample A1 in the field (A) $1000 \times$ magnification (B) with suggested identification $(\mathrm{C})$ 
A. Guth, MS Thesis, 2007

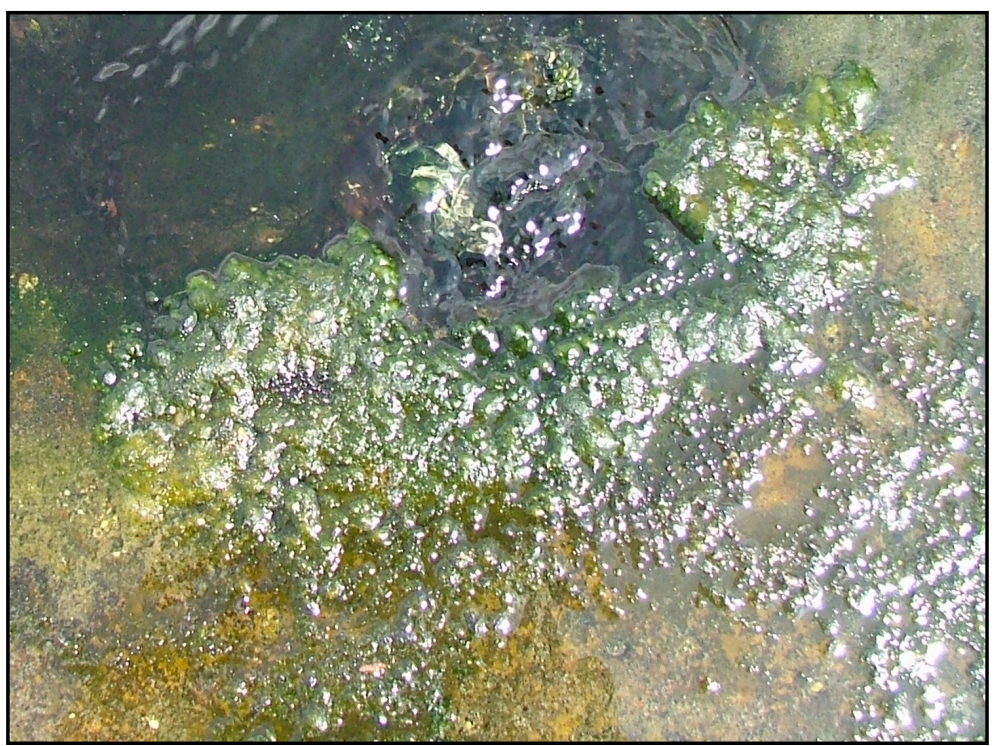

Left- A) In the field:

Sample A2 grew as

mucilaginous, bubble-

trapping films that floated on the water's surface.

Right- B) 640x magnification showing one of the infrequent diatoms seen in this sample, while the small green spherical cells compose the bulk of the A2 sample. It is suspected that these small green cells are Synechocystis (see $\mathrm{C}$ below).
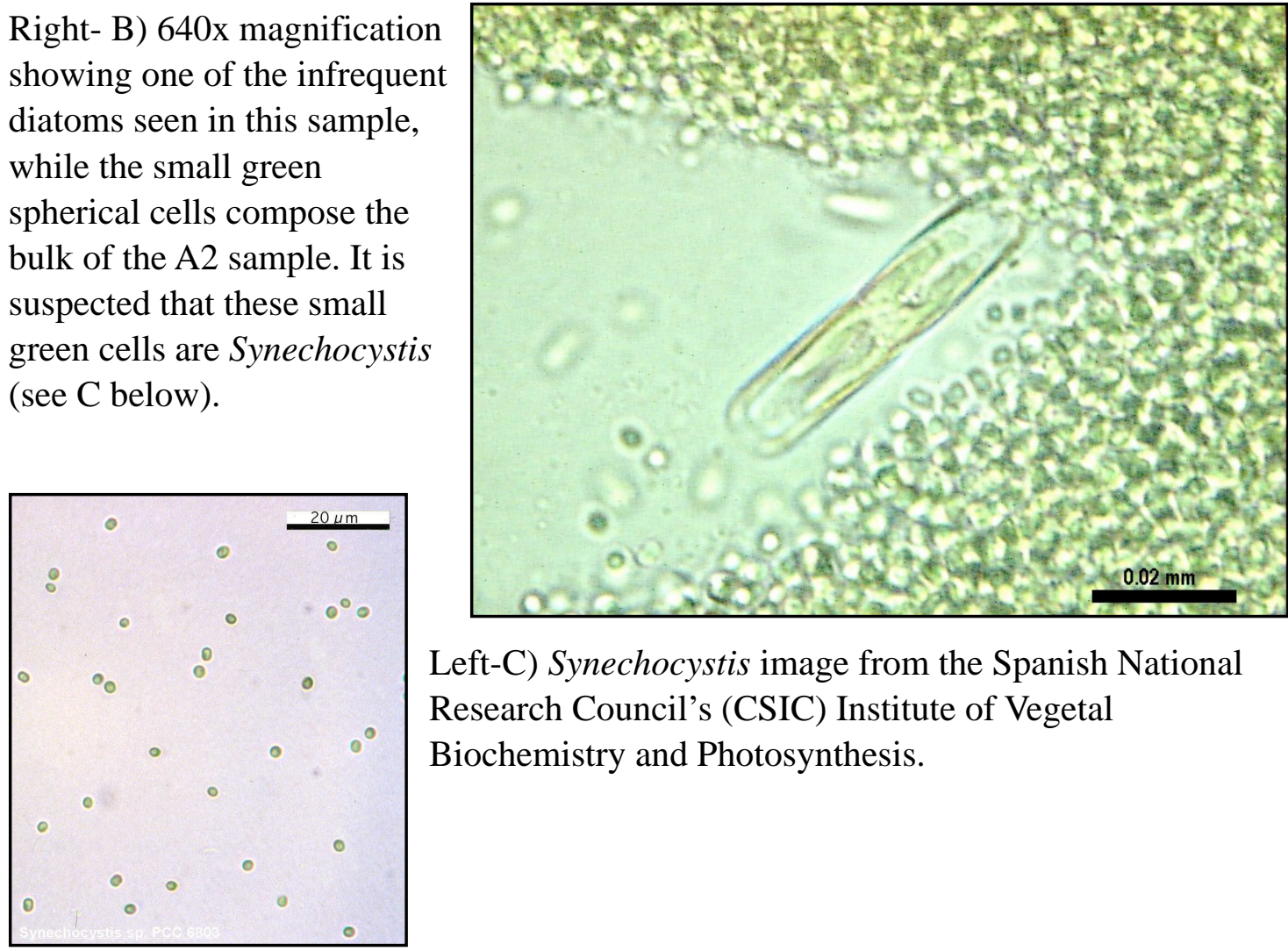

Figure 28: Images of biologic sample $A 2$ in the field (A), $640 \times$ magnification (B), with suggested identification $(C)$ 
A. Guth, MS Thesis, 2007

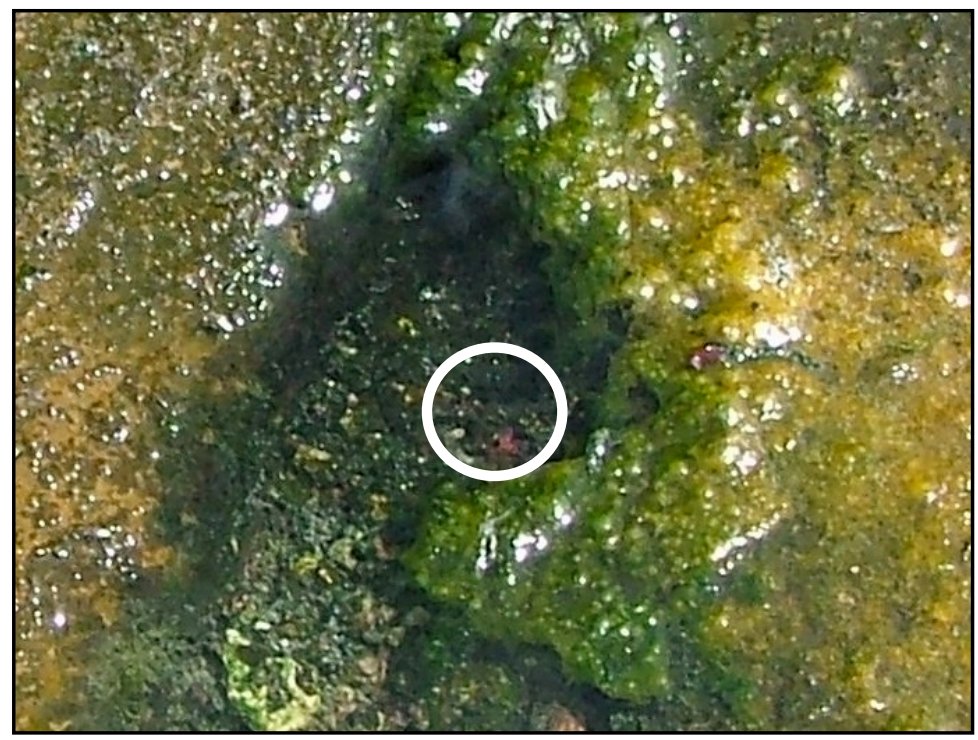

Left- A) In the field:

This red growth (circled)

was found at the mouth of a small spring, and was almost completely covered by green growth. The red was much more prominent during the 2005 field season which was earlier in the year and wetter than when this sample was collected in 2006

Right- B) 1000x magnification: This sample was composed mostly of fine filaments and small green spheres similar to those in sample A2 which are believed to be "contamination" from the overlying green growth. The filaments are segmented (black bars align with segments) with segments ranging between 6-9 microns long. These threads are believed to be Calothrix, a common mat forming bacteria (see C).

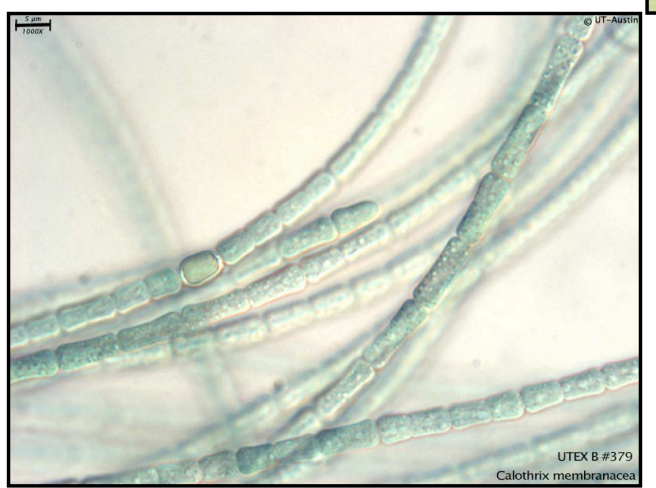

Left-C) 1000x Calothrix image from the UTEX image bank. A3 specimens shown above also resemble Phormidium or Schizothrix.

Figure 29: Images of sample A3 A) in the field B) at $1000 \times$ magnification C) Suggested identification 
A. Guth, MS Thesis, 2007

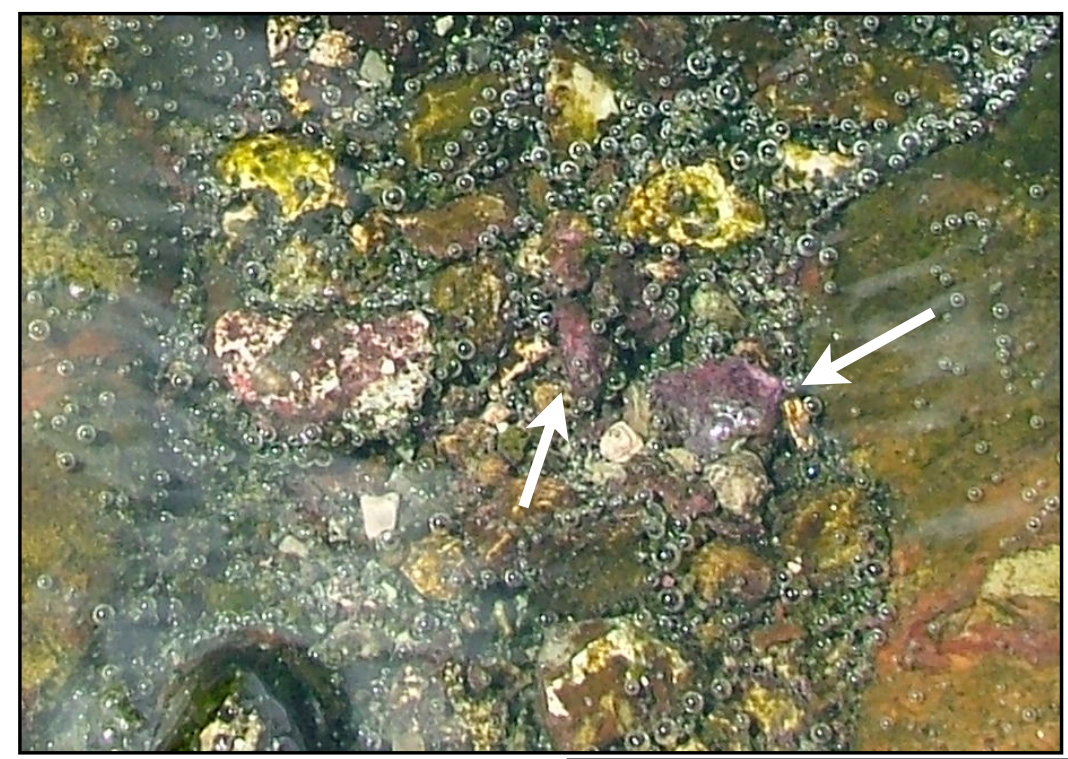

Left- A) In the field:

Purple growth that encrusted pebbles as indicated by the arrows.

Right- B) 1600x

magnification showing red, ovoid cells. Sample A4 is a mix of red and green cells as seen in $\mathrm{C}$ below. Red cells may be Synechococcus which may have a pink color according to CyanoDB.

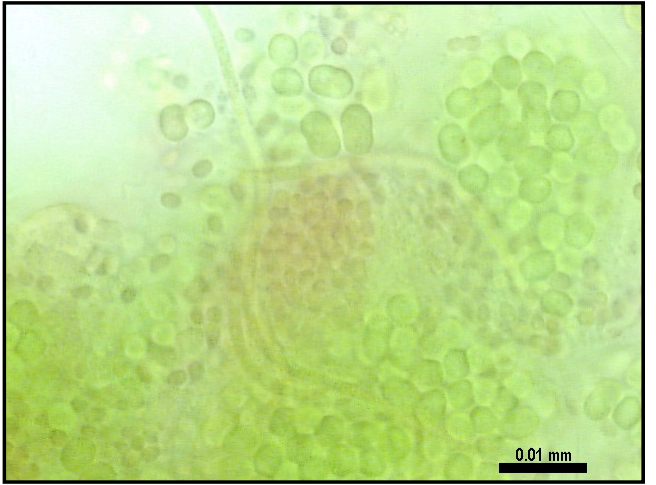

Left-C) 1000x magnification of $\mathrm{A} 4$ showing mixture of red and green cells.

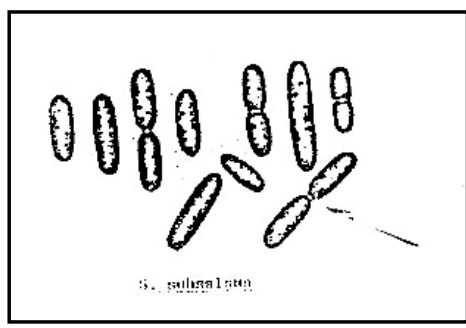

Above- D) image of

Synechococcus from CyanoDB.

Figure 30a: Images of sample A4 A) in the field. B) at $1600 \times$ magnification. C) 1000x magnification D) Suggested identification 
A. Guth, MS Thesis, 2007

Right- D)1600x magnification showing another common specimen that appears in sample A4. Though not seen here, they often appear in groups, and it is believed that this may be Spirulina subsalsa as shown in E below.

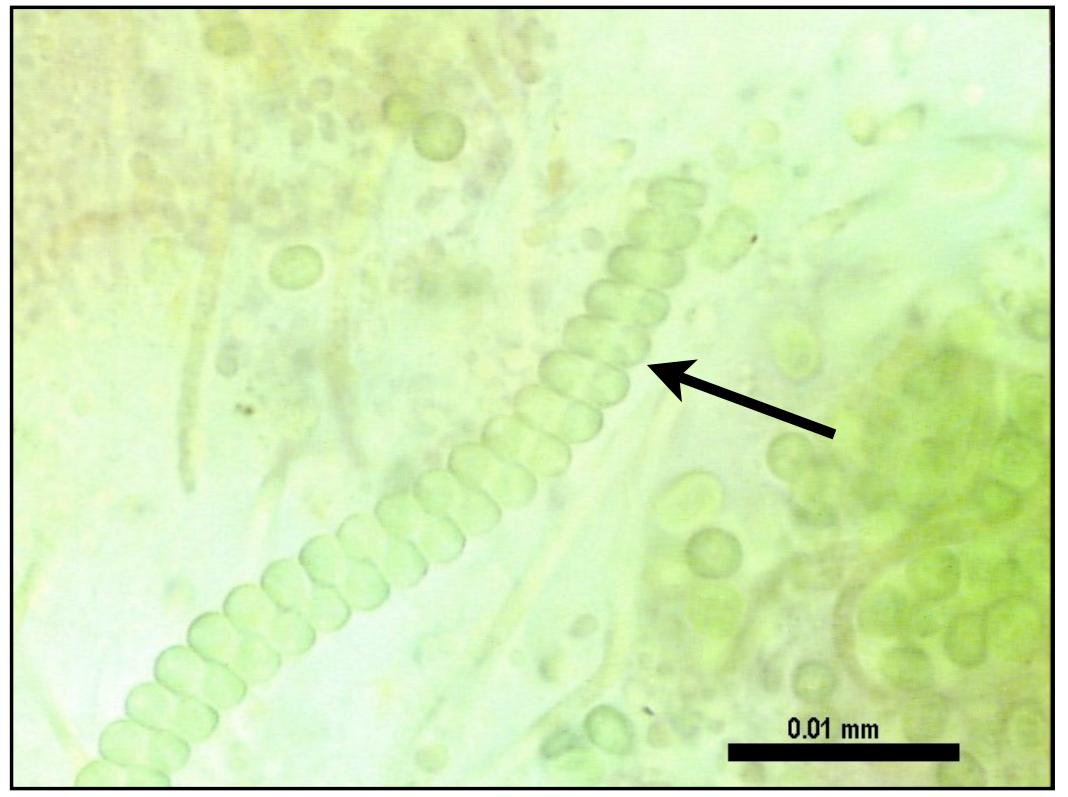

Right- E) Image of Spirulina subsalsa from the NIES (National Institute for Environmental Studies) Microbial Culture Collection.

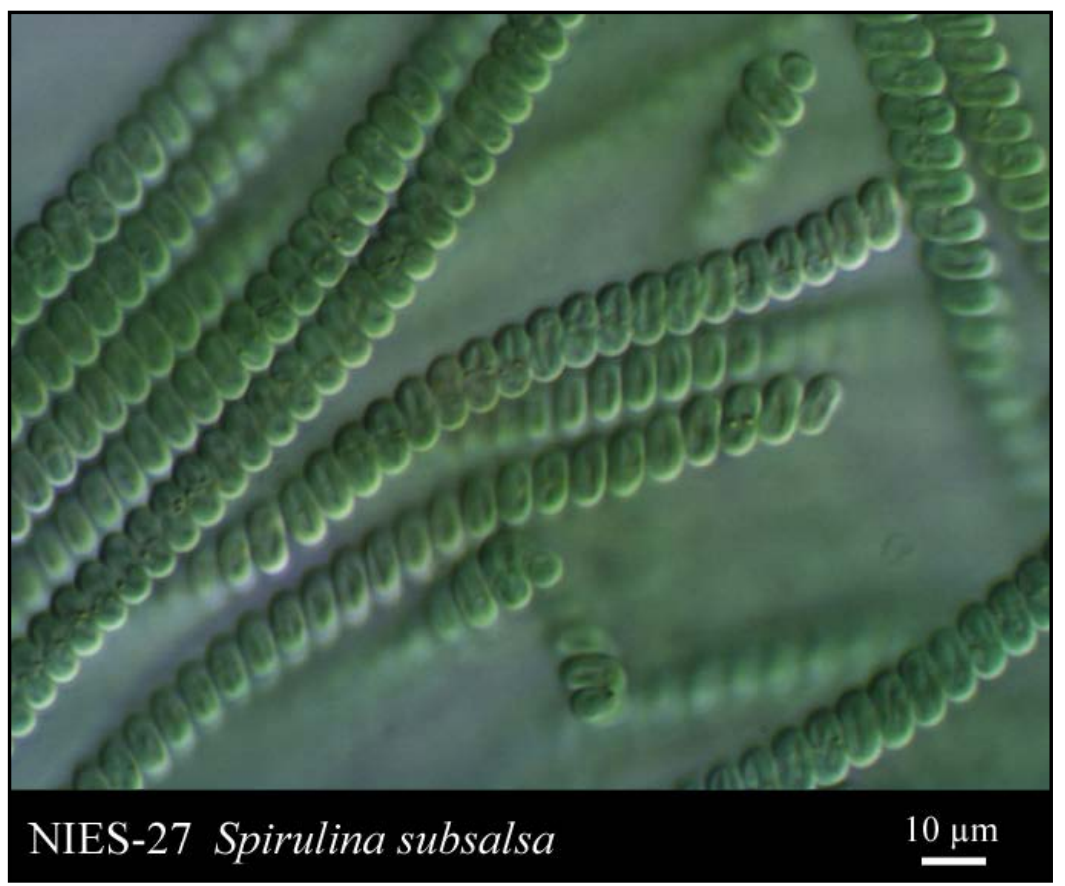

Figure 30b: D) additional common specimen in A4 E) suggested identification for D 
A. Guth, MS Thesis, 2007

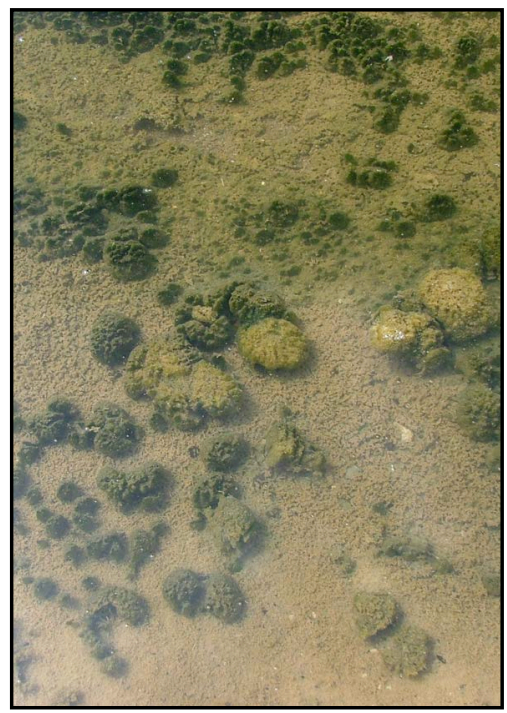

Left- A) In the field:

Sample A5 formed columnar mats (the image to the left is a top-down image, circular patches are the tops of the mats that are attached to the substrate and then rise above the floor) in areas of elevated temperature. Growths had a gritty texture, probably due to the entrainment of substrate. The inclusion of mineral grains in the sample made for difficult slide mounting as the incompressible grains would prevent the cover-slip from laying flat.

Right- B) 1000x magnification: A large bulk of the sample seemed to be detrital and the red/ orange tint seen on the left of image $\mathrm{B}$ may be due to ironbearing minerals. Also shown here are fine translucent filaments and an oblong cell which may be one of several species including the purple sulfur bacterium shown in $\mathrm{C}$ below.
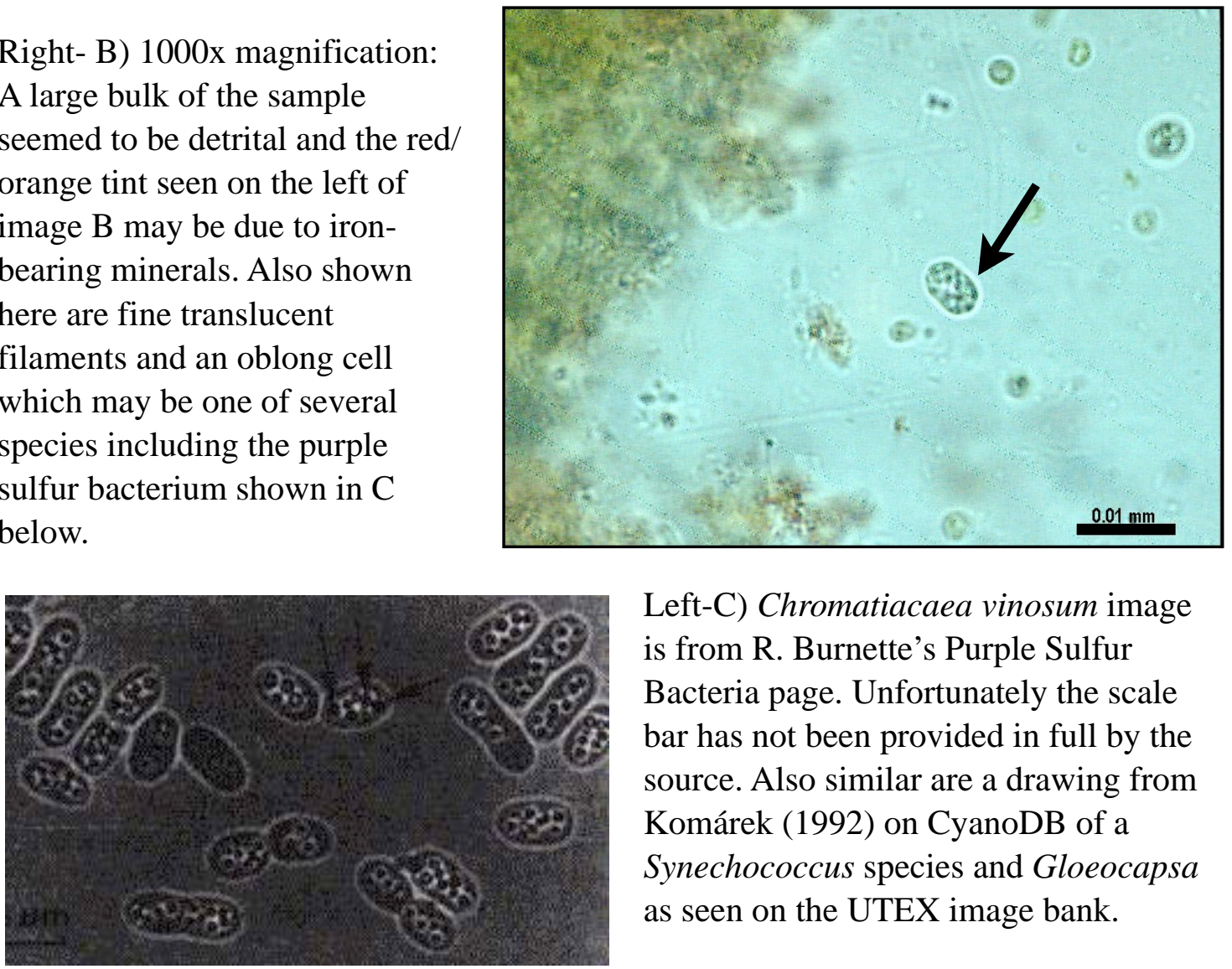

Left-C) Chromatiacaea vinosum image is from R. Burnette's Purple Sulfur Bacteria page. Unfortunately the scale bar has not been provided in full by the source. Also similar are a drawing from Komárek (1992) on CyanoDB of a Synechococcus species and Gloeocapsa as seen on the UTEX image bank.

Figure 31a: Images of sample A5 A) in the field. B) at $1000 \times$ magnification C) Suggested identification 
Right- D) 1600x magnification:

Segmented translucent filaments often seen in orange-tinted clumps. Image at right was selected to show the filament structure. These filaments comprise the bulk of the biologic sample, and are suspected to be Phormidium as in $\mathrm{E}$ below.
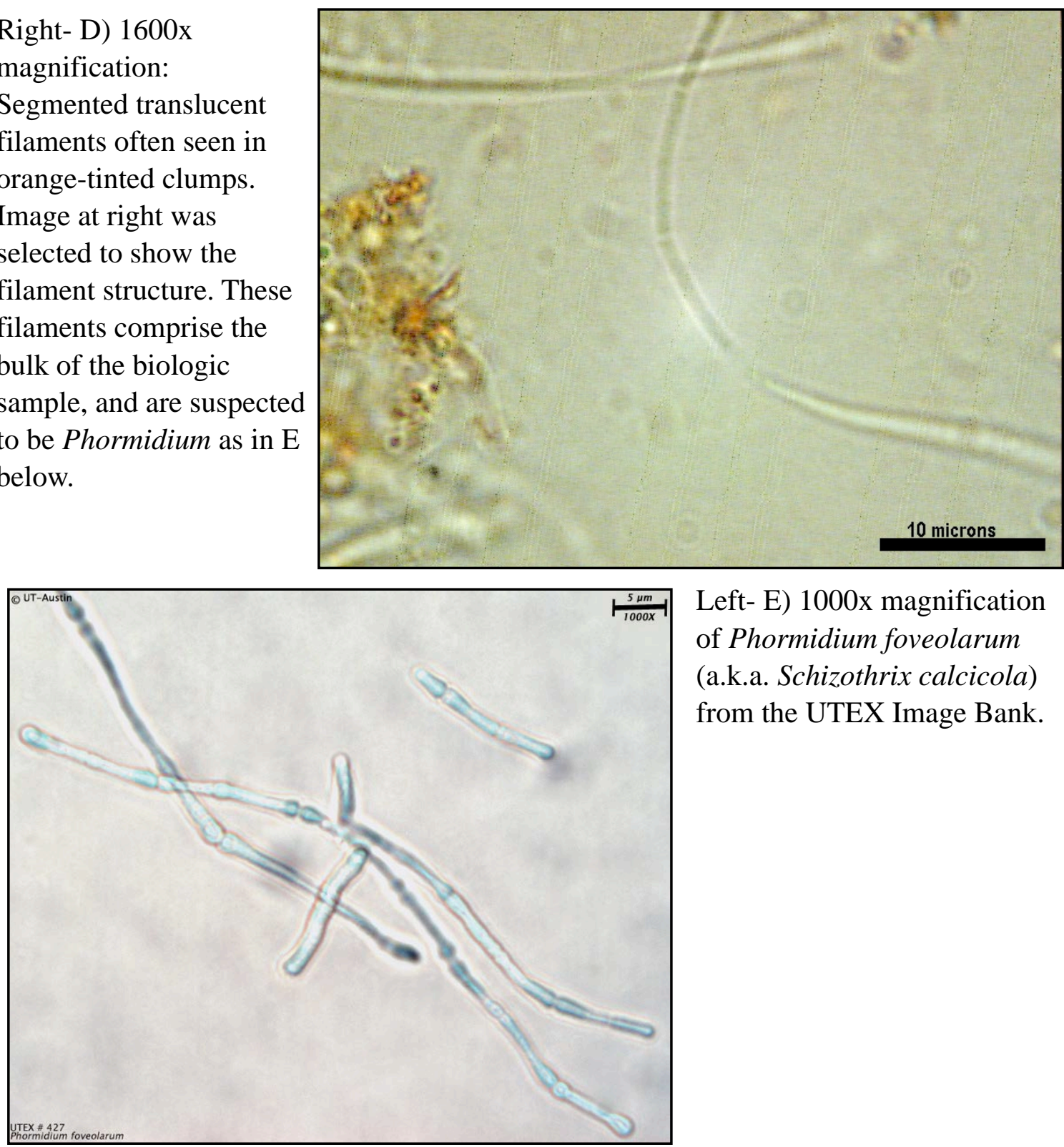

Left- E) 1000x magnification of Phormidium foveolarum (a.k.a. Schizothrix calcicola) from the UTEX Image Bank.

Figure 31b: D) 1600x magnification of filaments composing bulk of sample E) Suggested identification for $D$ 
A. Guth, MS Thesis, 2007

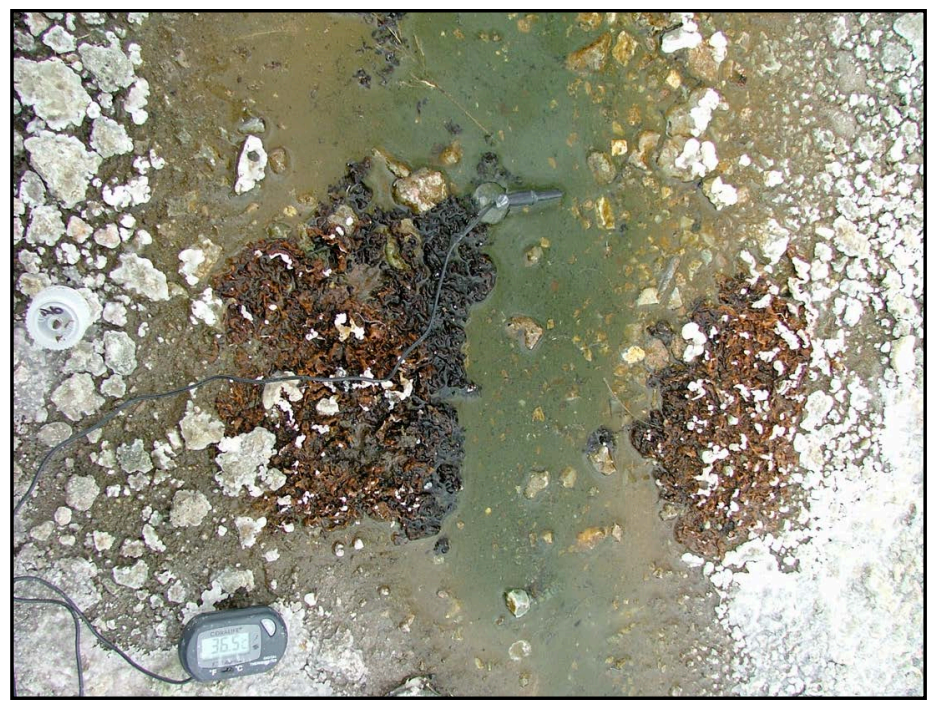

Left- A) Sample A6 is a matforming growth that is seen at very weak springs with virtually no competition. The environment where these growths are found is probably harsh as they were never totally submerged and the rapid evaporation deposits salts around the growths as seen in the lower right.

Right- B) 1000x magnification. While the image above is obviously red-brown, this color is not seen in the preserved sample to the right. It is believed that the non-green pigments may have deteriorated between collection and examination.
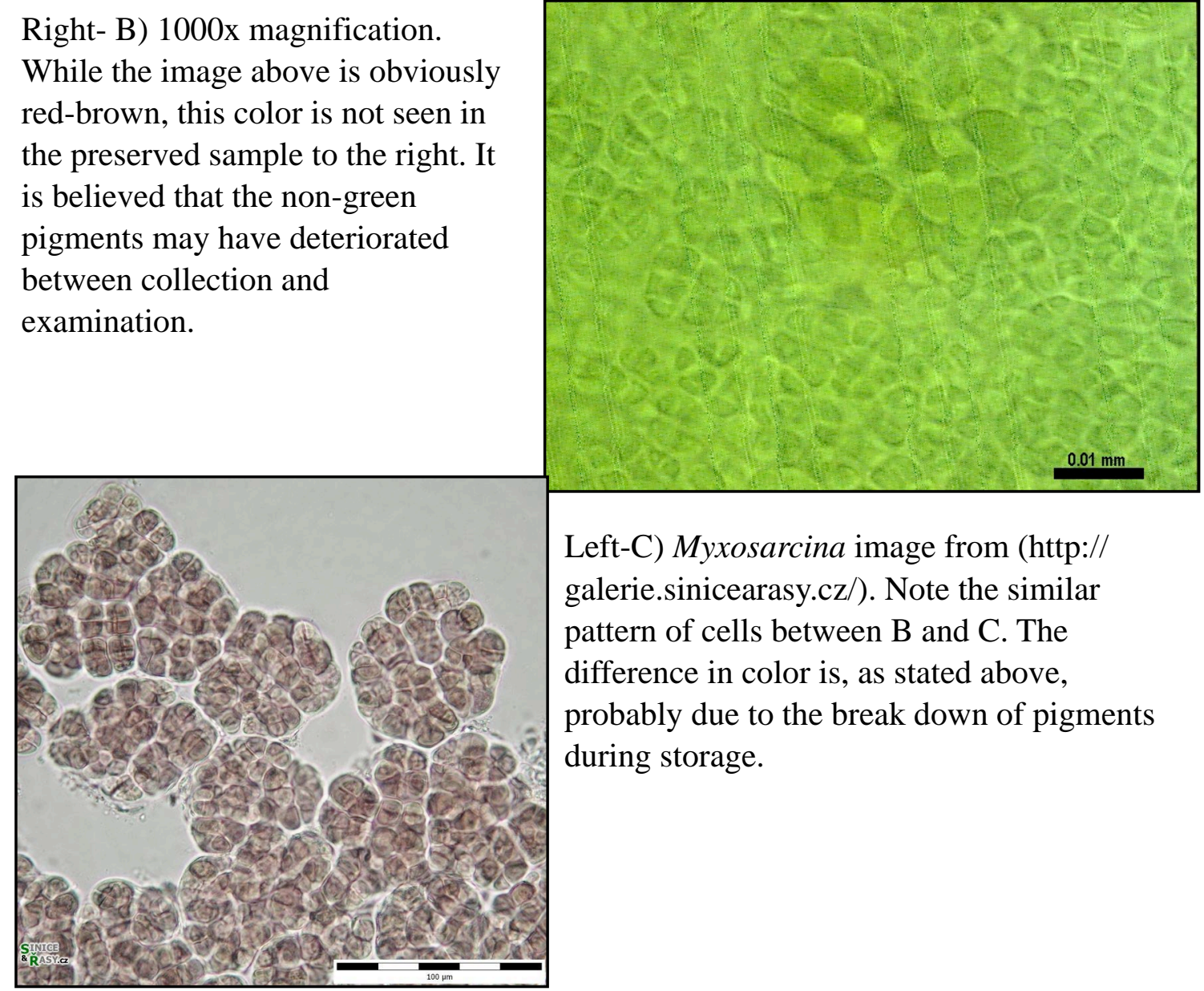

Left-C) Myxosarcina image from (http:// galerie.sinicearasy.cz/). Note the similar pattern of cells between B and C. The difference in color is, as stated above, probably due to the break down of pigments during storage.

Figure 32: Images of sample A6 in A) the field. B) at $1000 \times$ magnification with C) Suggested identification 
A. Guth, MS Thesis, 2007

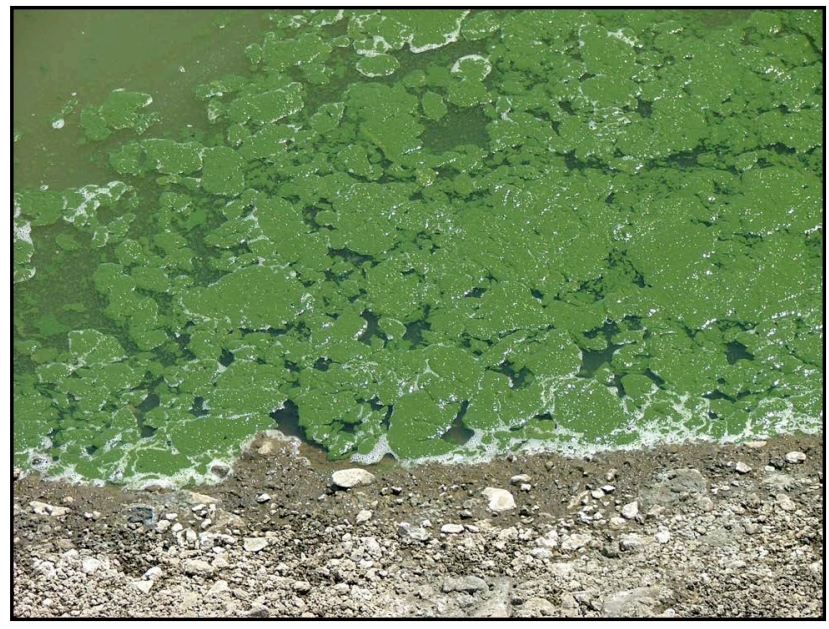

Left- A) In the field:

In one of the fresher pools near the salt concentration ponds this sample floated as a green scum on the water's surface. The same cyanobacteria that comprises the material floating on the surface is probably also responsible for the overall green color of the water.

Right-B) 640x magnification: This image shows two loose spirals that have been identified as Spirulina (see $\mathrm{C}$ below). Also pictured are an unidentified ovoid cell between the two spirals, and possibly a coiled mass of Anabaenopsis in the upper left (see D).

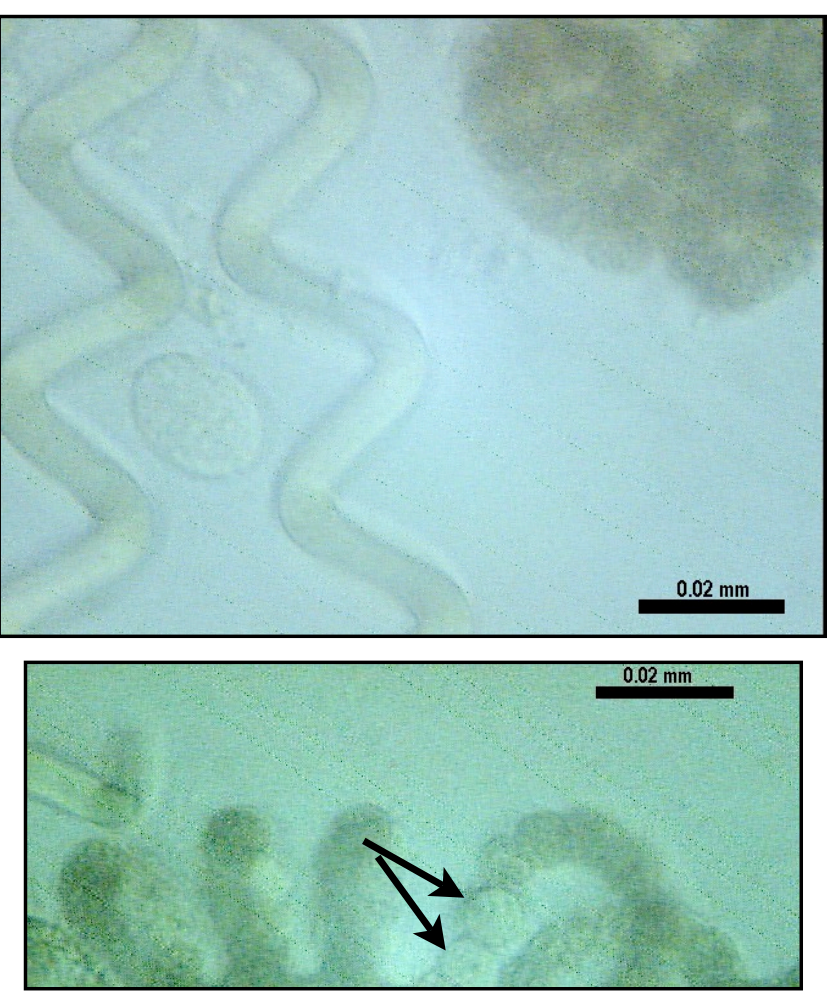

Above- D) 640x magnification: Possible Anabaenopsis. Image is only a partial due to an incomplete image capture. However, it appears Above-C) 400x image of Spirulina that there are two heterocysts together (arrows) platensis from the UTEX image bank. which distinguish this genus from Cyanospira.

Figure 33: Sample A7 A) in the field, B) at 640x magnification, C) suggested identification D) supplemental image of sample. 
A. Guth, MS Thesis, 2007

\section{Appendix B: Formation Correlation Chart}

The first two columns show geologic formations present in the map created for this study. Other columns represent the six original KGS maps that cover the study area. Each map is represented by 2 columns, one for formation name, and the other for formation symbology. Reading across the columns one can see what the formations present in the newly created map have been correlated with in the older maps. Formations that correlate directly between maps are found in the same rows, and similar formations that may not have a direct correlation are placed in the rows immediately below the formation they most are closely identified with.

Correlation is often based on what boundaries match across maps, or in some cases, what a formation had previously been mapped as. In cases where a formation was unrecognized or misidentified, the older, less favored identification is highlighted in grey. A number of formations that are present in the newly created map are not found in the older KGS maps, and instead have been mapped from sources found in more recent journal articles. 
Appendix B: Correlation of Geologic Formations

\begin{tabular}{|c|c|c|c|c|c|c|c|c|c|c|c|c|c|}
\hline \multirow{2}{*}{\multicolumn{2}{|c|}{\begin{tabular}{|l}
\multicolumn{1}{c}{ Guth - South Kenya } \\
Alkaline Lagoons \\
Alluvial Fans
\end{tabular}}} & \multicolumn{2}{|c|}{ Joubert - Namanga } & \multicolumn{2}{|c|}{ Baker- South Magadi } & \multirow[t]{2}{*}{ Matheson- Kajiado } & \multirow[t]{2}{*}{ Column4 } & \multicolumn{2}{|c|}{ Baker-Magadi } & \multicolumn{2}{|c|}{ Randel-Suswa } & \multicolumn{2}{|c|}{ Saggerson-Nairobi } \\
\hline & & & & \begin{tabular}{|l|} 
Alkaline Lagoons \\
Pebble Beds
\end{tabular} & $\begin{array}{l}\mathrm{Rt} \\
\mathrm{Qp}\end{array}$ & & & \begin{tabular}{|l|} 
Alkaline Lagoon \\
Boulder Beds
\end{tabular} & $\overline{R t^{\prime}}$ & Talus & Rt & & \\
\hline Ouaternerarv Sed & Or & \begin{tabular}{|l} 
Red Brown \\
Sandy soil \\
Black cotton soil \\
Grey sandy soil \\
Recent Terrestrial \\
Deposits \\
Calcareous \\
surface deposits
\end{tabular} & $\begin{array}{l}\text { Qr } \\
\text { Qb } \\
\text { Qg } \\
\text { Rt } \\
\text { Qc }\end{array}$ & Soils & Qr & $\begin{array}{l}\text { Loessic soil } \\
\text { black cotton soil } \\
\text { red volcanic soil } \\
\text { Grey sandy soil }\end{array}$ & $\begin{array}{l}\text { Qr } \\
\text { Qb } \\
\text { Qv } \\
\text { Qg }\end{array}$ & Loessic soil & Qr & Volcanic soils & Qv & \begin{tabular}{|l}
$\begin{array}{l}\text { Seds, loess, lake } \\
\text { deposits, diatomite }\end{array}$ \\
Terrestrial Deposits w/ \\
artifacts
\end{tabular} & $\begin{array}{l}\text { Qt2 } \\
\text { Qt1 }\end{array}$ \\
\hline Trona Beds & & & & & & & & Trona beds & Rt & & & & \\
\hline $\begin{array}{l}\text { High Magadi Beds } \\
\text { High Magadi- } \\
\text { pebble }\end{array}$ & $\begin{array}{l}\mathrm{Pl}-\mathrm{ml} \\
\mathrm{Pl}-\mathrm{ml}\end{array}$ & & & $\begin{array}{l}\text { High Magadi-clays } \\
\text { High Magadi- pebble }\end{array}$ & $\begin{array}{l}\text { Qt2 } \\
\text { Qt1 }\end{array}$ & & & High Magadi Beds & Qt & & & & \\
\hline Green Beds & PIC & & & Chert Series & Pll1 & & & Chert Series & $\mathrm{P} \| 2$ & & & & \\
\hline Kedong Flood & Pl-kf & & & & & & & Loessic soil & Qr & Seds & $\mathrm{Pl}$ & Kedong Valley Seds & Qvf \\
\hline Suswa Volcanics & S1-S10 & & & & & & & & & Suswa Volcanics & $\begin{array}{l}\text { Plp1-6, } \\
\text { Plt2-3, }\end{array}$ & & \\
\hline Orkaramatian Beds & Pl-ol & & & & & & & Loessic soil & $\mathrm{Qr}$ & & & & \\
\hline ash vents & Pl-va & & & & & & & ash vents & Plv6 & Basalt cinder cones & $\mathrm{Plb}$ & & \\
\hline Mau Ashes & Pl-ma & & & & & & & & & Mau Ashes & Plt1 & & \\
\hline Mosiro basalts & Pl-mb & & & & & & & & & Kirikiti basalts & Tvb1 & & \\
\hline \begin{tabular}{|l} 
Nyokie ash \\
Nyokie obsidian
\end{tabular} & $\begin{array}{l}\text { Pl-na } \\
\text { Pl-nv }\end{array}$ & & & $\begin{array}{l}\text { Pumic tuffs } \\
\text { trachytes }\end{array}$ & $\begin{array}{l}\text { Plv5 } \\
\text { Plv4 }\end{array}$ & & & $\begin{array}{l}\text { Nyegi pumice ash } \\
\text { Nyegi obsidian }\end{array}$ & $\begin{array}{l}\text { plv5 } \\
\text { plv4 }\end{array}$ & & & & \\
\hline Oloronga Beds & Pl-ogl & & & Oloronga Beds & $\mathrm{Pll} 2$ & & & \begin{tabular}{|l|} 
Loessic soil \\
Oloronga Beds
\end{tabular} & $\begin{array}{l}\text { Qr } \\
\text { Pll1 }\end{array}$ & & & & \\
\hline \begin{tabular}{|l} 
Olorgesailie Lake \\
Beds
\end{tabular} & Pl-okl & & & & & $\begin{array}{l}\text { Olorgesailie lake } \\
\text { beds }\end{array}$ & Pll & Olorgesailie Beds & $\mathrm{P} \| 3$ & & & & \\
\hline & & $\begin{array}{l}\text { Amboseli lake } \\
\text { beds }\end{array}$ & $\mathrm{PI}$ & & & & & & & & & & \\
\hline Kilimanjaro basalts & Pl-kv & $\begin{array}{l}\text { Kilimanjaro } \\
\text { basalts }\end{array}$ & Plv & & & & & & & & & & \\
\hline Gesumeti trachyte & Pl-gt & & & & & & & & & Alkali Trachyte & Plh2 & & \\
\hline Plateau Trachyte & Pl-pt & & & Plateau trachyte & Plv2 & Plateau Trachyte & Plh1 & Alkali trachytes & plv2 & $\begin{array}{l}\text { Alkali Trachyte } \\
{ }^{\star} \text { Note, this unit has } \\
\text { identified as sever } \\
\text { units, but part still } \\
\text { with what is known } \\
\text { as Plateau trac }\end{array}$ & $\begin{array}{l}\text { Plh2 } \\
\text { peen re- } \\
\text { different } \\
\text { rrelates } \\
\text { sewhere } \\
\text { ytes }\end{array}$ & & \\
\hline
\end{tabular}


Appendix B: Correlation of Geologic Formations

\begin{tabular}{|c|c|c|c|c|c|c|c|c|c|c|c|}
\hline \multicolumn{2}{|c|}{ Guth - South Kenya } & \multirow[t]{2}{*}{ Joubert - Namanga } & Baker-South Magadi & \multirow{2}{*}{\begin{tabular}{|l} 
Matheson- Kajiado \\
$\begin{array}{l}\text { OI Keju Ngiro Basalt } \\
\text { Alkali Trachyte }\end{array}$
\end{tabular}} & \multirow{2}{*}{$\begin{array}{c}\text { Column4 } \\
\text { Tvb } \\
\text { Plh1 }\end{array}$} & \multicolumn{2}{|c|}{ Baker-Magadi } & \multicolumn{2}{|l|}{ Randel-Suswa } & \multicolumn{2}{|c|}{ Saggerson-Nairobi } \\
\hline Tepesi Basalt & Pl-tb & & & & & & & \begin{tabular}{|l} 
Alkali Trachyte \\
Orthophyre trachyte
\end{tabular} & $\begin{array}{l}\text { Plh2 } \\
\text { Plh3 }\end{array}$ & & \\
\hline Limuru Pantellerite & PI-Iv & & & & & & & & & Limuru Trachyte & Plh1 \\
\hline Tepesi Benmoreite & PI-tv & & & Orthophyre trachyte & Plh2 & & & Orthophyre trachyte & Plh3 & & \\
\hline N. Kordjya trachyte & Pl-kt & & & Orthophyre trachyte & Plh2 & Orthophyre-trachyte & plv3 & $\begin{array}{l}\text { Alkali Trachyte } \\
\text { trachyte }\end{array}$ & $\begin{array}{l}\text { Plh2 } \\
\text { Plh3 } \\
\end{array}$ & & \\
\hline Leshuta trachyte & PII-It & & & & & & & & & & \\
\hline Ol Keju Nero & Pob & & & & & OI Keju Nero & tvb2 & & & & \\
\hline \multirow[t]{2}{*}{ Gelai } & Pgv & & & & & & & & & & \\
\hline & & & & & & & & Longonot trachyte & Plh5 & \begin{tabular}{|l|} 
Longonot trachyte \\
Kinari Tuffs \\
Mt Margaret \\
Rhyolite, comendites, \\
pantellerites, \\
trachyrhyolites \\
\end{tabular} & $\begin{array}{l}\text { Plh2 } \\
\text { Plt1 } \\
\text { Plt2 } \\
\\
\text { Plr }\end{array}$ \\
\hline Sambu & Psv & & & & & & & & & & \\
\hline Limuru Trachyte & Plt & & & Orthophyre trachyte & Plh2 & & & & & \begin{tabular}{|l|l|l} 
Limuru Trachyte \\
\end{tabular} & Plh1 \\
\hline \begin{tabular}{|l|} 
Ewaso Ngiro \\
Trachyte \\
\end{tabular} & Pet & & & & & Orthophyre-trachyte & plv3 & $\begin{array}{l}\text { Orthophyre- } \\
\text { trachyte }\end{array}$ & Plh3 & & \\
\hline Kordjya Basalt & Pkb & & Plateau trachyte & & & & & & & & \\
\hline \begin{tabular}{|l|} 
Tigoni Trachytes \\
Karura Trachytes \\
Kabete \\
Trachytes/Ruiru \\
Dam trachytes \\
\end{tabular} & $\begin{array}{l}\text { Ptt } \\
\text { Pkat }\end{array}$ & & & & & & & & & \begin{tabular}{|l|} 
Tigoni Trachytes \\
Karura Trachytes \\
Kabete Trachytes/Ruiru \\
Dam trachytes \\
\end{tabular} & $\begin{array}{l}\text { Tvt7 } \\
\text { Tvt6 } \\
\text { Tvt5 } \\
\end{array}$ \\
\hline $\begin{array}{l}\text { Upper Kercherwa } \\
\text { Valley Tuff } \\
\end{array}$ & Pka' & & & & & & & & & \begin{tabular}{|l|} 
mid-Upper Kerichwa \\
Valley Tuffs \\
\end{tabular} & Tvtf2 \\
\hline \begin{tabular}{|l} 
Lower Kerichwa \\
Valley Tuffs
\end{tabular} & Pka & & & & & & & & & $\begin{array}{l}\text { Lower Kerichwa Valley } \\
\text { Tuffs }\end{array}$ & Tvtf1 \\
\hline \begin{tabular}{|l}
$\begin{array}{l}\text { Shombole } \\
\text { volcanics }\end{array}$ \\
\end{tabular} & Pshv & & Shombole volcanics & & & & & & & & \\
\hline Mosiro Trachyte & Pmt & & & & & & & trachyte & Plh3 & & \\
\hline Singaraini Basalts & Psb & Miocene Basalts & Olivene basalts & OI Keju Ngiro Basalt & $\overline{T v b}$ & OI Keju Nero & tvb2 & & & & \\
\hline $\begin{array}{l}\text { Olorgesailie } \\
\text { volcanics } \\
\text { Olorgesailie } \\
\text { Nephelinite } \\
\end{array}$ & $\begin{array}{l}\text { Pov } \\
\text { Pon }\end{array}$ & & & $\begin{array}{l}\text { Olorgesailie } \\
\text { volcanics }\end{array}$ & Tvt2 & $\begin{array}{l}\text { Olorgesailie } \\
\text { trachytes } \\
\text { Olorgesailie } \\
\text { Nephelinite } \\
\end{array}$ & $\begin{array}{l}\text { Tvt } \\
\text { Tvn } \\
\end{array}$ & & & & \\
\hline Lenderut volcanics & Plv & & Lenderut volcanics & & & & & & & & \\
\hline Kirikiti Basalt & Pvb1 & & Kirikiti basalts & & & Kirikiti basalt & Tvb1 & Kirikiti basalts & Tvb1 & & \\
\hline & & & & & & & & & & Ololua Trachytes & Tvt3 \\
\hline Nairobi Trachytes & Pnt & & & & & & & & & Nairobi Trachytes & Tvt2 \\
\hline
\end{tabular}


A. Guth, MS Thesis, 2007

Appendix B: Correlation of Geologic Formations

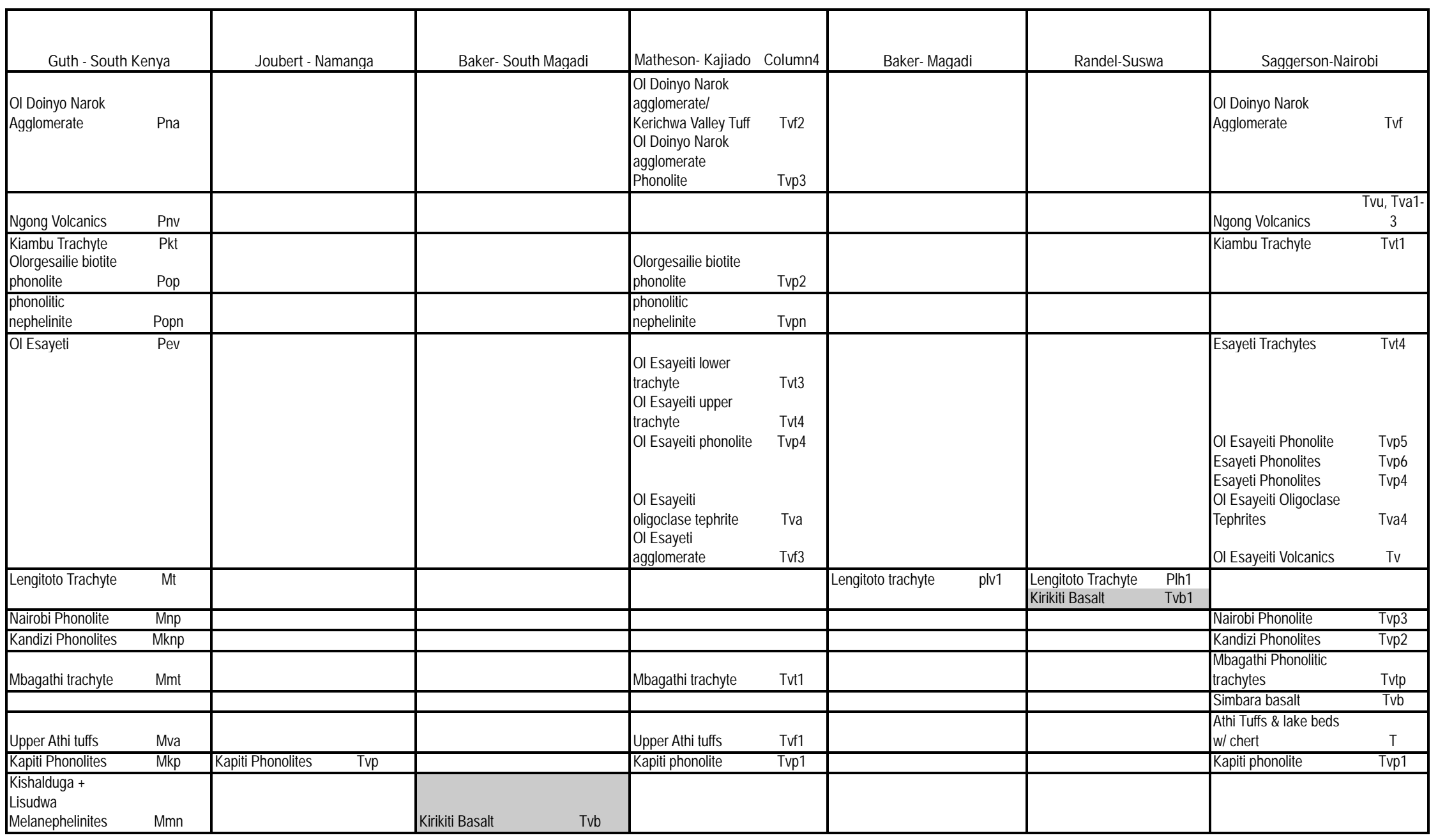


A. Guth, MS Thesis, 2007

Appendix B: Correlation of Geologic Formations

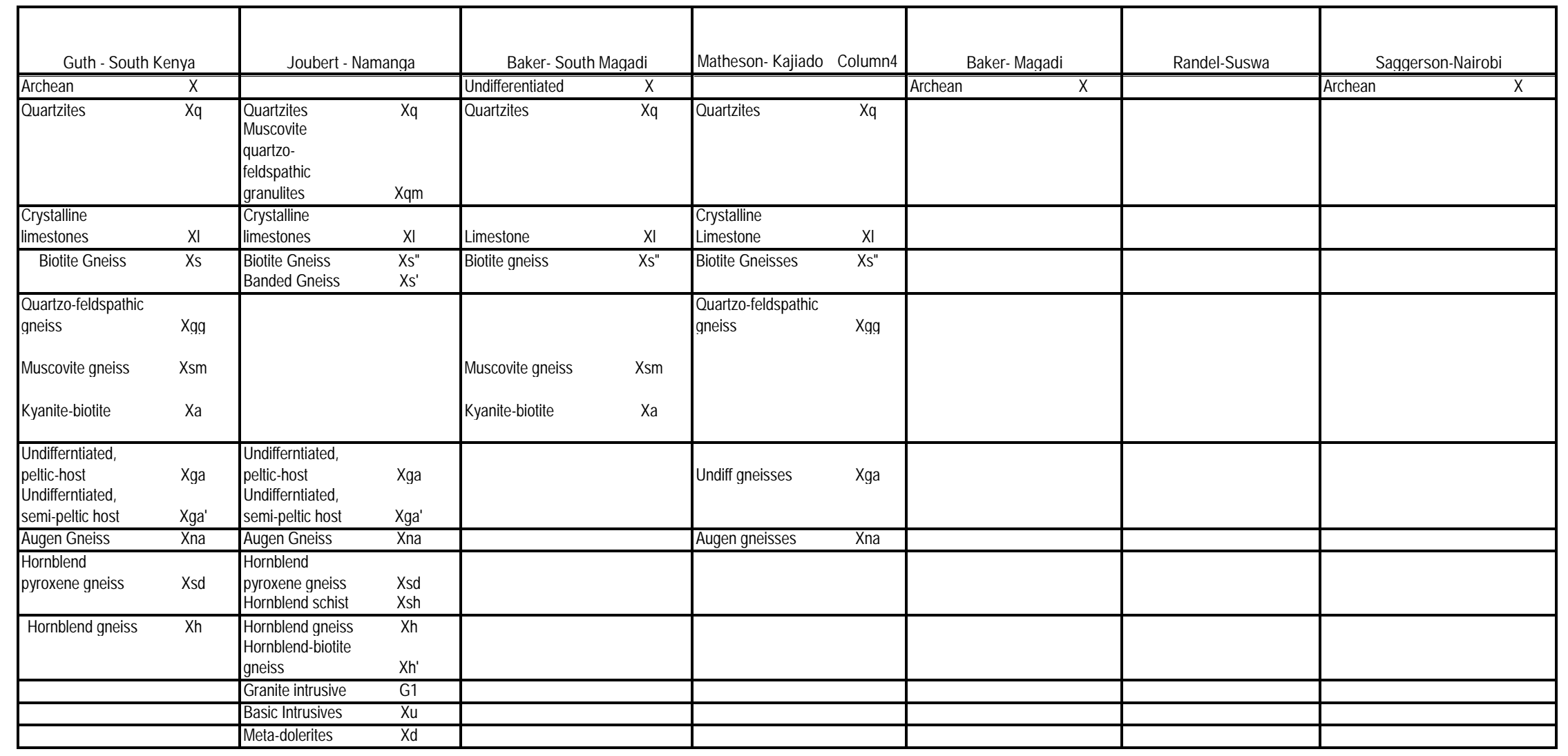


A. Guth, MS Thesis, 2007

\section{Appendix C: Age Dates for the Kenya Rift}

This is a chart showing the accumulated age dates from all sources and for all parts of the Kenya Rift. Formations are sorted by age, with the youngest at the top and the oldest at the bottom of the chart. Notes should be read carefully as there are some instances were an age date was called into question by a later author.

The final column is a "Quality Assessment" with values ranging between from 1 and 3, where values of 1 indicate an age date of dubious quality that should probably be reevaluated, and 3 indicates a newly obtained, well corroborated date. This is especially the case if the specific unit dated is considered pivotal (such as, a lava flow used to constrain the age of sediments or other flows) or the suspect date is the only one available for the entire formation. The Quality Assessment is gauged based on a variety of factors including age of the analysis, number of other dates that either corroborate or conflict with the date, dating method (K-Ar, Ar-Ar, whole rock, single crystal etc...) and assessed quality of other dates published along with the date in question. This is mainly to call attention to units or formations that should be re-dated to ensure an accurate image of the evolution of the rift. A number of age dates presented here are well outside the study area for this thesis, and due to unfamiliarity, quality assessments were not attempted for all age dates, in which case the field will be blank. 
Age Date Compilation for the Kenya Rift

\begin{tabular}{|c|c|c|c|c|c|c|c|c|c|c|}
\hline Unit Name & Event & Age Min & Age Max & Age Units & Uncertainty & Method & Author & Year & Notes & $\begin{array}{c}\text { Quality } \\
\text { Assessment }\end{array}$ \\
\hline Ol Doinyo Lengai & & 18 & & annum & & & Gittins and Jago & 1998 & 1988 June-Nov eruption & 3 \\
\hline Ol Doinyo Lengai ash & & 23 & & annum & & & Dawson, Pinkerton et al. & 1990 & 1983, small ash eruptions and small volume lava & 3 \\
\hline Ol Doinyo Lengai ash & & 40 & & annum & & & Dawson, Pinkerton et al. & 1990 & 1966 violent ash eruption & 3 \\
\hline Ol Doinyo Lengai & & 46 & & annum & & & Dawson, Pinkerton et al. & 1990 & 1960 eruption & 3 \\
\hline Suswa & & 100 & & annum & & & GVP & 2006 & ? Youngest flow is devoid of soil or vegetative cover & \\
\hline Longonot trachyte & & 200 & & annum & & & reported in Lagat & 2003 & $\begin{array}{l}\text { (Clarke et al. 1990) Most recent activity erupted onto the N and SW } \\
\text { flanks of the cone }\end{array}$ & \\
\hline Ololbutot comendite & & 250 & & annum & & & reported in Lagat & 2003 & $\begin{array}{l}\text { (Clarke et al. 1990) Youngest lava from the Upper Olkaria } \\
\text { Formation, 14C dated carbonized wood for age }\end{array}$ & \\
\hline Eastern Eburru pantellerites & & 400 & & annum & & & reported in Lagat & 2003 & (Clarke et al. 1990) youngest rocks of the Eburru volcano & \\
\hline & high lake level & 4.65 & & $\mathrm{ka}$ & & & hillaire-marcel et al. & 1986 & C14 date from tilapia at $605 \mathrm{~m}, \mathrm{SE}$ Magadi & \\
\hline Oncoids & & 5 & & $\mathrm{ka}$ & & & reported in Behr & 2002 & Tichy/Seegers & \\
\hline Na-silicates & & 6.3 & & $\mathrm{ka}$ & & & Goetz \& Hillaire-marcel & 1992 & isochron age & \\
\hline massive lahars, Meru crator collapse & & 7.8 & & $\mathrm{ka}$ & & & Wilkinson et al & 1986 & & \\
\hline & lake recessions & 9.1 & & $\mathrm{ka}$ & & & hillaire-marcel et al. & 1986 & strong volcanic activity, ashes killed tilapia & \\
\hline Little Magadi Trona & & 9.12 & & $\mathrm{ka}$ & & & Behr & 2002 & & \\
\hline High Magadi Beds & & 9.31 & & $\mathrm{ka}$ & & & reported in Behr & 2002 & tilapia, Tichy/Seegers & \\
\hline & $\begin{array}{l}\text { Magadi joined } \\
\text { with Natron }\end{array}$ & 10.2 & & ka & & & Roberts et al. & 1993 & & \\
\hline 3rd Gen. Stromatolites & & 10.3 & 11.4 & $\mathrm{ka}$ & & C14 & hillaire-marcel et al. & 1986 & corrected $\mathrm{C} 14$ age & \\
\hline & block lifting & 10.3 & 11.8 & $\mathrm{ka}$ & & & hillaire-marcel et al. & 1986 & displaced stromatloites found on Nguruman escarpment, $\sim 20 \mathrm{~m}$ lift & \\
\hline & $\begin{array}{l}\text { Magadi } \\
\text { intermediate }\end{array}$ & 10.7 & & $\mathrm{ka}$ & & & Roberts et al. & 1993 & deep enough to be stratified & \\
\hline & $\begin{array}{l}\text { Magadi lake } \\
\text { level minimum }\end{array}$ & 10.8 & & $\mathrm{ka}$ & & & Roberts et al. & 1993 & & \\
\hline & $\begin{array}{l}\text { Magadi } \\
\text { separated from } \\
\text { Natron }\end{array}$ & 10.9 & & ka & & & Roberts et al. & 1993 & & \\
\hline & $\begin{array}{l}\text { Magadi joined } \\
\text { with Natron }\end{array}$ & 11.1 & & $\mathrm{ka}$ & & & Roberts et al. & 1993 & lave level rise $58 \mathrm{~m}+$ from current & \\
\hline Travertine pipe & & 12 & & $\mathrm{ka}$ & & $\mathrm{Th} / \mathrm{U}$ & hillaire-marcel et al. & 1986 & corrected $\mathrm{Th} / \mathrm{U}$ age & \\
\hline High Magadi chert/magadiite & & 15 & & $\mathrm{ka}$ & & & Behr & 2002 & & \\
\hline High Magadi, Erionite silts & & 23.7 & & $\mathrm{ka}$ & & & reported in Williamson et al & 1993 & $\begin{array}{l}\text { Goetz } 1990,{ }^{*} \text { Note: C14 dates were also aquired for this section of } \\
\text { core but there was evidence for contamination by bacteria, so the } \\
\text { U/Th dates are preferred (Taieb et al. 1991) }\end{array}$ & \\
\hline Green beds & & 40 & & $\mathrm{ka}$ & & & reported in Williamson et al & 1993 & $\begin{array}{l}\text { Goetz } 1990, * \text { Note: C14 dates were also aquired for this section of } \\
\text { core but there was evidence for contamination by bacteria, so the } \\
\text { U/Th dates are preferred (Taieb et al.. 1991) }\end{array}$ & \\
\hline Meru main cone built & & 60 & 160 & $\mathrm{ka}$ & & & Wilkinson et al & 1986 & & \\
\hline Chert & & 96 & & $\mathrm{ka}$ & & & Goetz \&hillaire-marcel & 1992 & isochron age & \\
\hline Suswa & & 100 & & $\mathrm{ka}$ & +-0.01 & K-Ar & Baker et al. & 1988 & post-caldera, pre-Kedong flood, E flank & 3 \\
\hline Suswa & & 100 & & $\mathrm{ka}$ & $+1-0.01$ & K-Ar & Baker et al. & 1988 & post-caldera, post-Kedong flood, NE flank & 3 \\
\hline 2nd Gen Stromatolites & & 129 & 170 & $\mathrm{ka}$ & & & hillaire-marcel et al. & 1986 & Magadi Area & \\
\hline Meru alkaline lavas & & 160 & 350 & $\mathrm{ka}$ & & & Wilkinson et al & 1986 & alkaline lavas from $\mathrm{W}, \mathrm{NW}$ and $\mathrm{N}$ of Meru & \\
\hline Kilimanjaro, Kibo Caldera & & 210 & & $\mathrm{ka}$ & & & Wilkinson et al & 1986 & end of cone building period & \\
\hline Suswa & & 240 & & ka & $+/-0.01$ & K-Ar & Baker et al. & 1988 & Primitive shield eruption on rift floor & 3 \\
\hline Lake Baringo trachyte & & 260 & & $\mathrm{ka}$ & & & reported in Chapman and Brook & 1978 & Miller, whole rock analysis & \\
\hline 1 st Gen Stromatolites & & 290 & 304 & & & & hillaire-marcel et al. & 1986 & Natron area & \\
\hline
\end{tabular}


Age Date Compilation for the Kenya Rift

\begin{tabular}{|c|c|c|c|c|c|c|c|c|c|c|}
\hline Unit Name & Event & Age Min & Age Max & Age Units & Uncertainty & Method & Author & Year & Notes & $\begin{array}{c}\text { Quality } \\
\text { Assessment }\end{array}$ \\
\hline Oloronga & & 300 & & $\mathrm{ka}$ & & & Behr & 2002 & & \\
\hline Hannington phonolites & & 300 & & $\mathrm{ka}$ & & & Chapman and Brook & 1978 & Baringo basin & \\
\hline Lainyamok Khaki 1 & & 330 & & ka & & & Potts \& Deino & 1995 & isochron analysis & 3 \\
\hline Kilimanjaro, Rhombporphyry series & & 365 & & $\mathrm{ka}$ & & & reported in Baker et al & 1971 & Evernden and Curtis 1965 & \\
\hline Barajai trachytes & & 370 & 410 & $\mathrm{ka}$ & $\begin{array}{l}+/-0.02 \\
+/-0.03\end{array}$ & K-Ar & Baker et al. & 1988 & $\begin{array}{l}\text { S. of Suswa, prev. correlated w/ Magadi Trachyte, possibly related } \\
\text { to earliest Suswa activity }\end{array}$ & \\
\hline Lainyamok Khaki 2 & & 392 & & ka & & & Potts \& Deino & 1995 & isochron analysis & 3 \\
\hline Longonot & & 0.4 & & $\mathrm{Ma}$ & & & Lagat & 2003 & & \\
\hline Kilimanjaro, lower olivene basalts & & 0.42 & & Ma & & & reported in Baker et al & 1971 & Curtis (per. Comm, 1968) & \\
\hline Kilimanjaro, Lavaturm series & & 0.463 & & Ma & & & reported in Baker et al & 1971 & Evernden and Curtis 1965 & \\
\hline Olorgesailie M12-M14 & & 0.493 & 0.601 & Ma & & & $\begin{array}{l}\text { reported in Behrensmeyer \& } \\
\text { Potts et al. }\end{array}$ & 2002 & & 3 \\
\hline Loyamarok phonolite & & 0.5 & & Ma & & & reported in Chapman and Brook & 1978 & Miller, whole rock analysis & \\
\hline Kilimanjaro, Mawenzi & & 0.514 & & Ma & & & reported in Baker et al & 1971 & Evernden and Curtis 1965 & \\
\hline Ol Doinyo Nyokie & & 0.57 & 0.66 & Ma & $\begin{array}{l}+/-0.05 \\
+/-0.04\end{array}$ & K-Ar & Fairhead et al. & 1972 & dated obsidian, Reversed polarity & 2 \\
\hline Olorgesailie M10-14 & & 0.6 & 0.7 & $\mathrm{Ma}$ & & & Bye et al & 1987 & & 3 \\
\hline Oloronga & & 0.6 & & Ma & & & reported in Behr & 2002 & Kaufman et al & \\
\hline Mosiro basalt & & 0.6 & & $\mathrm{Ma}$ & & & reported in Crossley & 1979 & Knight, 1976 thesis & \\
\hline Olorgesailie M10-M12 & & 0.601 & 0.662 & Ma & & & $\begin{array}{l}\text { reported in Behrensmeyer \& } \\
\text { Potts et al. }\end{array}$ & 2002 & & 3 \\
\hline Lengorale trachyte & & 0.63 & 0.64 & $\mathrm{Ma}$ & & & reported in Baker et al & 1971 & SW of Magadi, Fitch and Miller unpub. & \\
\hline Ol Doinyo Nyokie & & 0.65 & 0.75 & Ma & & & Baker & 1976 & using Fairhead et al., 1972 date & 2 \\
\hline Kapthurin Frm & & 0.67 & & Ma & & & reported in Chapman and Brook & 1978 & Miller, whole rock analysis & \\
\hline Marsabit, youngest flows & & 0.68 & 0.76 & Ma & & & Key & 1987 & Marsabit area & \\
\hline Olorgesailie M1-9 & & 0.7 & 0.93 & Ma & & & Bye et al & 1987 & & 3 \\
\hline Olorgesailie M10 & & 0.71 & 0.74 & $\mathrm{Ma}$ & & K-Ar & Bye et al & 1987 & $\mathrm{~K} / \mathrm{Ar}$ from pumice & 3 \\
\hline Plateau trachytes & & 0.72 & 0.91 & Ma & & & reported in Baker et al & 1971 & W. of Magadi, Fitch and Miller unpub. & 2 \\
\hline Silbo Tuff & & 0.72 & & $\mathrm{Ma}$ & & & reported in Key and Watkins & 1988 & McDougall 1985, Koobi For a region, Ar-Ar date & \\
\hline Silbo Tuff & & 0.74 & & $\mathrm{Ma}$ & & & reported in Key and Watkins & 1988 & McDougall 1985, Koobi For a region, K-Ar date & \\
\hline Olorgesailie M7-M9 & & 0.746 & 0.78 & Ma & & & $\begin{array}{l}\text { reported in Behrensmeyer \& } \\
\text { Potts et al. }\end{array}$ & 2002 & & 3 \\
\hline Lava flow in Oloronga Lake Beds & & 0.78 & & Ma & $+/-0.04$ & K-Ar & Fairhead et al. & 1972 & $\begin{array}{l}\text { Key date used to date initiation of Oloronga beds. Noted by Bye et } \\
\text { al.. } 1987 \text { to be nearlv identical to Nvokie obsidian }\end{array}$ & \\
\hline Oloronga & & 0.8 & & Ma & & & reported in Behr & 2002 & Fairhead et al & 1 \\
\hline *Singaraini basalts & & 0.82 & 0.92 & Ma & $\begin{array}{l}+/-0.08 \\
+/-0.07\end{array}$ & K-Ar & Fairhead et al. & 1972 & $\begin{array}{l}\text { *Too young for Singaraini Basalts, Of the samples Fairhead et al. } \\
\text { examine, these have the most Atmos. Argon contamination. Sample } \\
\text { location } 5 \text { miles East of Singaraini station, so abnormal dates may } \\
\text { he due to alteration/contamination }\end{array}$ & 1 \\
\hline Plateau trachytes & & 0.84 & & $\mathrm{Ma}$ & $+/-0.03$ & K-Ar & Fairhead et al. & 1972 & Reverse polarity & 2 \\
\hline Kilimanjaro, lower olivene basalts & & 0.85 & 1.1 & Ma & & & reported in Baker et al & 1971 & Curtis (per. Comm, 1968) & \\
\hline Plateau trachytes & & 0.86 & 0.89 & Ma & $+/-0.03$ & K-Ar & Fairhead et al. & 1972 & Normal polarity & 2 \\
\hline Magadi Trachyte & & 0.89 & 0.92 & Ma & & & Potts \& Deino & 1995 & from floor and walls of Lainyamok graben & 3 \\
\hline Gesumeti trachyte & & 0.9 & 1.25 & Ma & NA & NA & Baker and Mitchell & 1976 & $\begin{array}{l}\text { not specifically dated, but have reversed magnetic polarities, overlie } \\
\text { the Limuru trachytes, and are older than the Plateau trachytes of the } \\
\text { Kedong Gorge. Note that these age estimates are quite different than } \\
\text { the ages nresented in Raker of al } 1988 \text { of } 195-21 \mathrm{Ma}\end{array}$ & 2 \\
\hline
\end{tabular}


Age Date Compilation for the Kenya Rift

\begin{tabular}{|c|c|c|c|c|c|c|c|c|c|c|}
\hline Unit Name & Event & Age Min & Age Max & Age Units & Uncertainty & Method & Author & Year & Notes & $\begin{array}{c}\text { Quality } \\
\text { Assessment }\end{array}$ \\
\hline Hannington phonolites & & \begin{tabular}{ll|}
0.9 \\
\end{tabular} & $\mid 1.1$ & $\overline{\mathrm{Ma}}$ & & & Chapman and Brook & 1978 & Baringo basin & \\
\hline Plateau trachytes & & 0.93 & & Ma & $+1-0.06$ & K-Ar & Baker and Mitchell & 1976 & top flow in scarp, NW of Olorgesailie N.P. & 3 \\
\hline Olorgesailie M1-M5 & & 0.974 & 0.992 & Ma & & & $\begin{array}{l}\text { reported in Behrensmeyer \& } \\
\text { Potts et al. }\end{array}$ & 2002 & & 3 \\
\hline Plateau trachytes & & 0.98 & 1.23 & Ma & $\begin{array}{l}+/-0.04 \\
+/-0.02\end{array}$ & K-Ar & Baker et al. & 1988 & & 3 \\
\hline${ }^{*}$ Kirikiti Basalts & & 1 & & $\mathrm{Ma}$ & $+/-0.01$ & K-Ar & Fairhead et al. & 1972 & *Too young for Kirikiti Basalts & 1 \\
\hline Marsabit, main shield & & 1.13 & & Ma & & & Key & 1987 & Marsabit area & \\
\hline Plateau trachytes & & 1.17 & & $\mathrm{Ma}$ & $+/-0.04$ & K-Ar & Baker and Mitchell & 1976 & bottom flow in scarp, NW of Olorgesailie N.P. & 3 \\
\hline & $\begin{array}{l}\text { WNW-ESE } \\
\text { faulting }\end{array}$ & 1.18 & 1.23 & Ma & & & reported in Wilkinson et al & 1986 & & \\
\hline "Kirikiti Basalts & & 1.27 & 1.31 & Ma & $\begin{array}{l}+/-0.08 \\
+/-0.09\end{array}$ & K-Ar & Fairhead et al. & 1972 & *Too young for Kirikiti Basalts & 1 \\
\hline *Singaraini basalts & & 1.31 & 1.44 & Ma & $\begin{array}{l}+/-0.06 \\
+/-0.05\end{array}$ & K-Ar & Fairhead et al. & 1972 & $\begin{array}{l}\text { *Too young for Singaraini Basalts, noted by Fairhead to have } \\
\text { Normal Polarity, so rocks may have Argon imbalance. Sample } \\
\text { location South of Ol Esakut, and may be sampled of Ol Tepesi } \\
\text { Racalts instead }\end{array}$ & 1 \\
\hline Intra-Moinik basalt & & 1.33 & 1.38 & Ma & $\begin{array}{l}+/-0.05 \\
+/-0.09\end{array}$ & & Thouveny and Taieb & 1986 & At base of the Moinik Formation, Natron area & \\
\hline Humbu Formation & & 1.35 & & $\mathrm{Ma}$ & & & reported in Mora et al. & 2003 & Natron, $40 \mathrm{~m}$ thick, mostly alluvial & \\
\hline Moinik Formation & & 1.35 & 1.15 & Ma & & & reported in Mora et al. & 2003 & Natron, $30-40 \mathrm{~m}$ thick, lacustrine & 3 \\
\hline Plateau trachytes & & 1.36 & 1.42 & Ma & & & reported in Baker et al & 1971 & Magadi Area, Fitch and Miller unpub. & 2 \\
\hline Chari Tuff & & 1.38 & & Ma & & & reported in Key and Watkins & 1988 & McDougall 1985, Koobi For a region, Ar-Ar date & \\
\hline Chari Tuff & & 1.39 & & Ma & & & reported in Key and Watkins & 1988 & McDougall 1985, Koobi For a region, K-Ar date & \\
\hline Ol Tepesi basalt & & 1.4 & 1.6 & $\mathrm{Ma}$ & & & Baker et al. & 1988 & & 3 \\
\hline Magadi Trachyte & & 1.4 & & Ma & & & Crossley & 1979 & & 3 \\
\hline Ol Tepesi basalt & & 1.42 & & $\mathrm{Ma}$ & $+1-0.06$ & K-Ar & Baker and Mitchell & 1976 & Reverse polarity & 3 \\
\hline Chemeron Frm & & 1.5 & & Ma & & & Chapman and Brook & 1978 & Baringo basin - $200 \mathrm{~m}$ sed unit, age range from bracketting lavas & \\
\hline Kapsalop phonolite & & 1.5 & 2.1 & Ma & & & Chapman and Brook & 1978 & Baringo basin & \\
\hline Ndau mugearite & & 1.5 & & Ma & & & reported in Chapman and Brook & 1978 & Everndam and Curtis, whole rock analysis & \\
\hline Meru area volcanics & & 1.5 & & $\mathrm{Ma}$ & & & Wilkinson et al & 1986 & alkali volcanics 100 s meters thick & \\
\hline Limuru trachytes & & 1.55 & 1.59 & Ma & & & reported in Baker et al & 1971 & Fitch and Miller unpub. & 2 \\
\hline Wa Mbugu basalt & & 1.55 & 2.27 & Ma & $\begin{array}{l}+/-0.03 \\
+/-0.06\end{array}$ & & Thouveny and Taieb & 1986 & $\begin{array}{l}\text { Intercalated with the Humbu basaltic tuff, normally magnetized, } \\
\text { Natron area }\end{array}$ & \\
\hline Hannington phonolites & & 1.6 & & Ma & & & Chapman and Brook & 1978 & Baringo basin & \\
\hline Ol Keju Nero Basalts & & 1.64 & 1.79 & Ma & NA & NA & Baker and Mitchell & 1976 & not dated, between 2 dated units, Normal polarity & \\
\hline Ol Tepesi benmoreite & & 1.65 & & $\mathrm{Ma}$ & $+1-0.06$ & K-Ar & Baker and Mitchell & 1976 & Reverse polarity & 3 \\
\hline Kordjya basalts & & 1.66 & & $\mathrm{Ma}$ & $+/-0.05$ & K-Ar & Baker and Mitchell & 1976 & top flow in scarp W side of Kordjya depression & 3 \\
\hline Limuru trachytes & & 1.66 & 1.68 & Ma & $+/-0.02$ & K-Ar & Baker et al. & 1988 & $\begin{array}{l}\text { Ages may be too young due to potential argon loss. Dated } \\
\text { pantelleritic obsidians were hydrated and had lost Na and Fe, so } \\
\text { argon loss is suspected. }\end{array}$ & 1 \\
\hline Marsabit, basal unit & & 1.7 & & Ma & & & Key & 1987 & Marsabit area & \\
\hline Limuru trachytes & & 1.72 & & Ma & & & reported in Baker et al & 1971 & Evernden and Curtis 1965 & 2 \\
\hline Plateau trachytes & & 1.74 & & Ma & & & reported in Baker et al & 1971 & Nairobi-Magadi road, Everndam and Curtis 1965 & 2 \\
\hline Kordjya basalts & & 1.76 & & Ma & $+1-0.06$ & K-Ar & Baker and Mitchell & 1976 & 2nd flow in scarp & 3 \\
\hline Sambu lavas & & 1.77 & 1.9 & $\mathrm{Ma}$ & & & reported in Mora et al. & 2003 & Isaac and Curtis 1974 & 2 \\
\hline Marsabit, main shield & & 1.78 & & Ma & & & Key & 1987 & Marsabit area & \\
\hline
\end{tabular}


Age Date Compilation for the Kenya Rift

\begin{tabular}{|c|c|c|c|c|c|c|c|c|c|c|}
\hline Unit Name & Event & Age Min & Age Max & Age Units & Uncertainty & Method & Author & Year & Notes & $\begin{array}{c}\text { Quality } \\
\text { Assessment }\end{array}$ \\
\hline Ol Tepesi benmoreite* & & 1.81 & & Ma & $+/-0.05$ & K-Ar & Baker and Mitchell & 1976 & $\begin{array}{l}\text { This age is considered high, possibly due to too much argon- } \\
\text { magnetic results agree more with the age of } 1.65 \mathrm{Ma}\end{array}$ & 2 \\
\hline Limuru trachytes & & 1.84 & & $\mathrm{Ma}$ & $+1-0.06$ & K-Ar & Baker and Mitchell & 1976 & & 3 \\
\hline Malbe Tuff & & 1.85 & & Ma & & & reported in Key and Watkins & 1988 & McDougall 1985, Koobi For a region, Ar-Ar date & \\
\hline Malbe Tuff & & 1.86 & & Ma & & & reported in Key and Watkins & 1988 & McDougall 1985, Koobi For a region, K-Ar date & \\
\hline KBS Tuff & & 1.88 & & Ma & & & reported in Key and Watkins & 1988 & McDougall 1985, Koobi For a region, K-Ar and Ar-Ar date & \\
\hline Ainapno mugearites & & 1.9 & & Ma & & & Chapman and Brook & 1978 & Baringo basin & \\
\hline Mosiro trachyte & & 1.9 & 2.3 & $\mathrm{Ma}$ & & & reported in Cossley and Knight & 1981 & Knight, 1976 thesis & \\
\hline Limuru trachytes & & 1.91 & & $\mathrm{Ma}$ & $+/-0.06$ & K-Ar & Baker and Mitchell & 1976 & Reverse polarity & 3 \\
\hline Kulal Shield, Basal Unit & & 1.91 & & $\mathrm{Ma}$ & & & Key & 1987 & Marsabit area & \\
\hline Limuru trachytes & & 1.94 & & $\mathrm{Ma}$ & $+/-0.06$ & K-Ar & Baker and Mitchell & 1976 & & 3 \\
\hline Limuru trachytes & & 1.94 & 2.64 & $\mathrm{Ma}$ & & & Baker et al. & 1988 & & 3 \\
\hline Gesumeti trachyte & & 1.95 & 2.1 & Ma & $\begin{array}{l}+/-0.02, \\
+/-0.04\end{array}$ & K-Ar & Baker et al. & 1988 & $\begin{array}{l}\text { *note: previously correlated with Plateau trachytes, but age dates } \\
\text { and } \mathrm{Zr} / \mathrm{Nb} \text { ratios are similar to Limuru trachytes. Considered by } \\
\text { Baker at al. to be localized fissure eruptions of Limuru trachyte } \\
\text { magma }\end{array}$ & \\
\hline Limuru trachytes & & 1.96 & & $\mathrm{Ma}$ & $+1-0.04$ & K-Ar & Baker and Mitchell & 1976 & & 3 \\
\hline Shombole & & 1.96 & & Ma & $\begin{array}{l}+/-0.07 \\
+/-0.05\end{array}$ & K-Ar & Fairhead et al. & 1972 & Reverse polarity & 2 \\
\hline & $\mathrm{N}$-S faulting & 1.97 & 2.37 & Ma & & & Wilkinson et al & 1986 & synchronous w/ Tarosero faulting (2.1 Ma) & \\
\hline Kaperyon Frm* & & 2 & & Ma & & & Chapman and Brook & 1978 & $\begin{array}{l}\text { Baringo basin - } 130 \mathrm{~m} \text { sed unit, *noted, that the original } 1971 \\
\text { mapping of this unit by Chapman included } 3 \text { units of different ages, } \\
\text { Mpesida beds (7Ma), Lukeino Frm (6.5 Ma) and Chemeron Frm (2- } \\
4 \mathrm{Ma})\end{array}$ & \\
\hline Songoiwa mugearite & & 2 & & Ma & & & reported in Chapman and Brook & 1978 & Everndam and Curtis, whole rock analysis & \\
\hline Penini group basalt base & & 2 & & $\mathrm{Ma}$ & & & reported in Mora et al. & 2003 & Thouveny and Taieb 1987, $10 \mathrm{~m}$ thick & 3 \\
\hline Hajaro basalt & & 2 & & Ma & & K-Ar & Thouveny and Taieb & 1986 & Curtis (Isaac 1967), is reversely magnetized, Natron area & 2 \\
\hline Sambu lavas & & 2.02 & & $\mathrm{Ma}$ & & & reported in Baker et al & 1971 & Curtis (Isaac 1967) & 2 \\
\hline Asie Shield, Upper Unit & & 2.04 & 2.07 & Ma & & & Key & 1987 & Marsabit area & \\
\hline Gombe Group & & 2.07 & & Ma & & & Wilkinson & 1988 & Allia Bay area, N. Kenya, K/Ar dating, whole rock & \\
\hline Ewaso Ngiro trachyte & & 2.1 & & Ma & & & Crossley & 1979 & & 3 \\
\hline Kordiya basalts & & 2.17 & & Ma & $+/-0.10$ & K-Ar & Baker and Mitchell & 1976 & 11th flow in scarp & 3 \\
\hline Olorgesailie & & 2.2 & 2.7 & Ma & & & Baker et al. (a) & 1977 & & \\
\hline Olorgesailie & & 2.21 & & $\mathrm{Ma}$ & $+/-0.06$ & K-Ar & Fairhead et al. & 1972 & Sampled Olorgesailie & 2 \\
\hline Gombe Group & & 2.25 & & Ma & & & Wilkinson & 1988 & Allia Bay area, N. Kenya, K/Ar dating, whole rock & \\
\hline Singaraini basalts & & 2.31 & & Ma & $+/-0.10$ & K-Ar & Baker and Mitchell & 1976 & flow top in scarp at Singaraini trig. Station & 3 \\
\hline Singaraini basalts & & 2.33 & & Ma & $+/-0.09$ & K-Ar & Baker and Mitchell & 1976 & lowest flow in scarp at Singaraini trig station & 3 \\
\hline Koobi Fora beds & & 2.37 & 2.64 & Ma & & & reported in Baker et al & 1971 & Lake Rudolf. Fitch and Miller 1970 & \\
\hline Olorgesailie & & 2.4 & & Ma & $+/-0.07$ & K-Ar & Fairhead et al. & 1972 & Normal polarity, Sample from Shanamu & 2 \\
\hline Lenderut volcano & & 2.5 & 2.7 & $\mathrm{Ma}$ & & & Baker and Mitchell & 1976 & referenced Baker 1963 & 2 \\
\hline Emsos mugearite & & 2.5 & & $\mathrm{Ma}$ & & & Chapman and Brook & 1978 & Baringo basin - Laikipia escarpment & \\
\hline Kirikiti basalts & & 2.5 & 2.7 & $\mathrm{Ma}$ & & & Crossley & 1979 & & 3 \\
\hline Kanapoi basalt & & 2.5 & 2.9 & $\mathrm{Ma}$ & & & reported in Baker et al & 1971 & Geochron lab (Patterson, 1966;Patterson and Howells 1967) & \\
\hline Koobi Fora beds & & 2.5 & 3.45 & Ma & & & reported in Baker et al & 1971 & Lake Rudolf, Fitch and Miller 1970 & \\
\hline Ngong Basanite & & 2.53 & 2.58 & Ma & & & Saggerson & 1991 & $\begin{array}{l}\text { rock collected by Curtiss, Evernden and Miller. Whole rock K/Ar } \\
\text { dated }\end{array}$ & 2 \\
\hline Lenderut & & 2.53 & & $\mathrm{Ma}$ & $+1-0.08$ & K-Ar & Fairhead et al. & 1972 & Normal polarity & 2 \\
\hline
\end{tabular}


Age Date Compilation for the Kenya Rift

\begin{tabular}{|c|c|c|c|c|c|c|c|c|c|c|}
\hline Unit Name & Event & Age Min & Age Max & Age Units & Uncertainty & Method & Author & Year & Notes & $\begin{array}{c}\text { Quality } \\
\text { Assessment }\end{array}$ \\
\hline Olorgesailie & & 2.6 & 2.62 & Ma & $\begin{array}{l}+/-0.06 \\
+/-0.08\end{array}$ & K-Ar & Fairhead et al. & 1972 & Normal polarity, samples from both Shanamu and Olorgesailie & 2 \\
\hline Lenderut & & 2.62 & & $\mathrm{Ma}$ & $+/-0.07$ & K-Ar & Fairhead et al. & 1972 & Normal polarity & 2 \\
\hline $\begin{array}{l}\text { Basalt flow younger than Kingangop } \\
\text { tuff }\end{array}$ & & 2.63 & & Ma & $+/-0.04$ & K-Ar & Baker et al. & 1988 & $\begin{array}{l}6.1 \mathrm{~km} \text { ESE of Naivasha township, gives minimum age for tuff } \\
\text { formation }\end{array}$ & 3 \\
\hline Mt Kenya nepheline syenite plug & & 2.64 & & Ma & & & reported in Baker et al & 1971 & Evernden and Curtis 1965 & \\
\hline Kirikiti basalts & & 2.68 & & Ma & $+/-0.16$ & K-Ar & Baker and Mitchell & 1976 & 5th flow in scarp & \\
\hline Narosura pyro. & & 2.7 & & Ma & & & Crossley & 1979 & & \\
\hline Asie Shield, Basal Unit & & 2.7 & & Ma & & & Key & 1987 & Marsabit area & \\
\hline Olorgesailie trachyte & & 2.7 & & Ma & & & reported in Baker et al & 1971 & Evernden and Curtis 1965, Anorthoclase K-Ar dated & 2 \\
\hline Kanapoi basalt & & 2.71 & & $\mathrm{Ma}$ & & & reported in Baker et al & 1971 & Gilbert (Patterson et. Al 1971) & \\
\hline Kirikiti basalts & & 2.93 & & $\mathrm{Ma}$ & $+/-0.20$ & K-Ar & Baker and Mitchell & 1976 & top flow in scarp & 3 \\
\hline Ninikaa Tuff & & 3.01 & & Ma & & & reported in Key and Watkins & 1988 & McDougall 1985, Koobi For a region, Ar-Ar date & \\
\hline Ninikaa Tuff & & 3.06 & & $\mathrm{Ma}$ & & & reported in Key and Watkins & 1988 & McDougall 1985, Koobi For a region, K-Ar date & \\
\hline Kirikiti basalts & & 3.1 & & Ma & +-0.2 & K-Ar & Baker and Mitchell & 1976 & 9th flow in scarp & 3 \\
\hline Mt Kenya volcanics & & 3.1 & & Ma & & & reported in Baker et al & 1971 & Evernden and Curtis 1965 & \\
\hline Gombe Group & & 3.1 & & Ma & & & Wilkinson & 1988 & Allia Bay area, N. Kenya, K/Ar dating, whole rock & \\
\hline Nairobi trachyte & & 3.17 & 3.45 & Ma & & & reported in Baker et al & 1971 & Fitch and Miller unpub., Whole rock K-Ar dated & 2 \\
\hline Bulal basalt & & 3.2 & & $\mathrm{Ma}$ & & & Ebinger et al. & 2000 & SW Ethiopia & \\
\hline Toroto Tuff & & 3.31 & & Ma & & & reported in Key and Watkins & 1988 & McDougall 1985, Koobi For a region, Ar-Ar date & \\
\hline Toroto Tuff & & 3.33 & & Ma & & & reported in Key and Watkins & 1988 & McDougall 1985, Koobi For a region, K-Ar date & \\
\hline trachyte in Kinangop tuffs & & 3.34 & & $\mathrm{Ma}$ & & & reported in Baker et al & 1971 & Evernden and Curtis 1965 & \\
\hline Harr basalt & & 3.4 & & Ma & & & Ebinger et al. & 2000 & SW Ethiopia & \\
\hline Isolated Basalt Plateau & & 3.44 & & Ma & & & Key & 1987 & Marsabit area & \\
\hline Ribkwo volcano - Ribon trachyte & & 3.5 & 3.9 & Ma & & & Chapman and Brook & 1978 & & \\
\hline Sambu lavas (Kirikiti basalts?) & & 3.5 & & Ma & & & reported in Mora et al. & 2003 & $\begin{array}{l}\text { Isaac and Curtis 1975, possibly Kirikiti basalts underlaying the } \\
\text { Sambu basalts? (Alex Guth) }\end{array}$ & 1 \\
\hline Ol Esayeti & & 3.6 & 6.7 & $\mathrm{Ma}$ & & & Baker and Mitchell & 1976 & & 2 \\
\hline Tirr Tirr volcanics & & 3.6 & 3.9 & $\mathrm{Ma}$ & & & reported in Baker et al & 1971 & F.M. Consultants for GSK unpub & \\
\hline Bulal lavas & & 3.61 & & Ma & & & Key and Watkins & 1988 & Sabarei Area, N. Kenya & \\
\hline Ol Esayeiti & & 3.61 & & Ma & $+/-0.10$ & K-Ar & Fairhead et al. & 1972 & Reverse polarity & 2 \\
\hline Kingangop tuff & & 3.65 & 3.68 & Ma & $\begin{array}{l}+/-0.07, \\
+/-0.08\end{array}$ & K-Ar & Baker et al. & 1988 & Obsidian fiamma from ash & 3 \\
\hline Sill in Lothagam group & & 3.71 & & $\mathrm{Ma}$ & & & reported in Baker et al & 1971 & Gilbert (Patterson et. Al 1971) & \\
\hline Kaparaina basalt & & 3.96 & 4.67 & Ma & & & reported in Chapman and Brook & 1978 & $\begin{array}{l}\text { Dagley et al. 1976, Baringo Basin, Ndau River exposure, near base } \\
\text { of most complete continuous sequence of this unit }\end{array}$ & \\
\hline Mursi basalt & & 4 & & $\mathrm{Ma}$ & & & Ebinger et al. & 2000 & SW Ethiopia & \\
\hline Moiti Tuff & & 4.1 & & $\mathrm{Ma}$ & & & reported in Key and Watkins & 1988 & McDougall 1985, Koobi For a region, K-Ar date & \\
\hline Eldama Ravine Tuff & & 4.2 & 4.4 & $\mathrm{Ma}$ & & & Chapman and Brook & 1978 & Baringo basin - Kamasia E. foothills, South of $0.5^{\circ} \mathrm{North}$ & \\
\hline Kinodo phonolites & & 4.2 & & Ma & & & Chapman and Brook & 1978 & $\begin{array}{l}\text { Baringo basin - Laikipia escarpment, stratigraphically above } \\
\text { Tasokwan trachyte, but several ages from one sample were } \\
\text { determined to be } 11.5-12 \mathrm{Ma}\end{array}$ & \\
\hline Loisiumurto volcanics & & 4.2 & & Ma & & & Crossley & 1979 & & \\
\hline Ribkwo volcano & & 4.5 & 5.5 & Ma & & & reported in Chapman and Brook & 1978 & Baringo basin - low angle trachyte volcano & \\
\hline Ribkwo volcano - Ribon trachyte & & 4.7 & 5.1 & $\mathrm{Ma}$ & & & Chapman and Brook & 1978 & & \\
\hline Marti Illaut basalt & & 4.7 & & $\mathrm{Ma}$ & & & Charsley & 1987 & Laisamis area, Northern Kenya & \\
\hline Isolated Basalt Plateau & & 4.7 & & Ma & & & Key & 1987 & S. End of Marti Engweta Plateau, Marsabit area & \\
\hline
\end{tabular}


Age Date Compilation for the Kenya Rift

\begin{tabular}{|c|c|c|c|c|c|c|c|c|c|c|}
\hline Unit Name & Event & Age Min & Age Max & Age Units & Uncertainty & Method & Author & Year & Notes & $\begin{array}{c}\text { Quality } \\
\text { Assessment }\end{array}$ \\
\hline Kerichwa valley tuff / Nairobi Stone & & 4.84 & 5.67 & Ma & & & reported in Baker et al & 1971 & $\begin{array}{l}\text { Langata, Nairobi, Fitch and Miller unpub, Sanidine and } \\
\text { Anorthoclase K-Ar dated }\end{array}$ & 2 \\
\hline Lengitoto trachytes & & 5 & 5.5 & $\mathrm{Ma}$ & & & reported in Crossley & 1979 & L.A.J. Williams, per. Comm. 1975' & 2 \\
\hline Kirikiti basalts* & & 5.03 & 5.07 & Ma & & & reported in Baker et al & 1971 & $\begin{array}{l}\text { Fitch and Miller unpub., *note from crossley-may be from unit older } \\
\text { than kirikiti }\end{array}$ & 1 \\
\hline Kaparaina basalt & & 5.1 & 5.6 & $\mathrm{Ma}$ & & & Chapman and Brook & 1978 & Baringo basin - Kamasia E. foothills, North of $0.5^{\circ}$ North & \\
\hline Kirikiti basalts* & & 5.13 & & Ma & & & reported in Baker et al & 1971 & $\begin{array}{l}\text { Fitch and Miller unpub. *note from crossley-may be from unit older } \\
\text { than kirikiti }\end{array}$ & 1 \\
\hline Nairobi phonolite & & 5.2 & & Ma & & & reported in Baker et al & 1971 & $\begin{array}{l}\text { Evernden and Curtis 1965, from Beacon ranch quarry, Anorthoclase } \\
\text { K-Ar dated }\end{array}$ & 1 \\
\hline Tasokwan trachyte & & 5.5 & & Ma & & & Chapman and Brook & 1978 & $\begin{array}{l}\text { Baringo basin - Laikipia escarpment, possibly equivalent to } \\
\text { Kabarnet trachyte }\end{array}$ & \\
\hline Upper Tinderet volcanics & & 5.5 & 5.8 & Ma & & & reported in Baker et al & 1971 & F.M. Consultants for GSK unpub & \\
\hline $\begin{array}{l}\text { "Simbara series"/ Sirrima Basalt (see } \\
\text { Note) }\end{array}$ & & 5.5 & & Ma & & & reported in Baker et al & 1971 & $\begin{array}{l}\text { F.M. Consultants for GSK unpub, *Note, according to Smith } 1994, \\
\text { this sample was probably from the Sirrima Basalts which are } \\
\text { contemporaneous with Thomson's Falls Phonolites. The Simbara } \\
\text { series is most likelv nver 12 Ma }\end{array}$ & 1 \\
\hline Ol Esayeiti & & 5.64 & 5.85 & Ma & & & reported in Baker et al & 1971 & Fitch and Miller unpub. Tephrite, feldspar K-Ar dated & 2 \\
\hline Olorgesailie neph. & & 5.8 & & $\mathrm{Ma}$ & & & reported in Baker et al & 1971 & Evernden and Curtis 1965 & 2 \\
\hline Lengitoto trachytes & & 5.8 & & $\mathrm{Ma}$ & & & reported in Crossley & 1979 & Knight, 1976 thesis & \\
\hline Olorgesailie phonolite & & 5.83 & & Ma & & & Saggerson & 1991 & $\begin{array}{l}\text { rock collected by Curtiss, Evernden and Miller. Nepheline K/Ar } \\
\text { dated }\end{array}$ & 2 \\
\hline Thomson's Falls phonolites & & 6.2 & 6.7 & Ma & & & reported in Baker et al & 1971 & F.M. Consultants for GSK unpub & \\
\hline Kabarnet trachytes & & 6.4 & & Ma & & & Chapman and Brook & 1978 & Baringo basin- Kamasia Range & \\
\hline Kapkut volcano & & 6.4 & 6.8 & Ma & & & Chapman and Brook & 1978 & Baringo basin - Kamasia E. foothills, South of $0.5^{\circ}$ North & \\
\hline Kaparaina basalt & & 6.4 & & Ma & & & Chapman and Brook & 1978 & Baringo basin - Kamasia E. foothills, South of $0.5^{\circ}$ North & \\
\hline Kaparaina basalt & & 6.7 & 7.1 & Ma & & & Chapman and Brook & 1978 & Baringo basin - Kamasia E. foothills, South of $0.5^{\circ} \mathrm{North}$, & \\
\hline Ol Esayeiti & & 6.7 & & Ma & & & reported in Baker et al & 1971 & Evernden and Curtis 1965 & 2 \\
\hline Lengitoto trachytes & & 6.9 & & Ma & & & Crossley & 1979 & & 3 \\
\hline Ewalel Phonolite & & 7 & 7.6 & Ma & & & Chapman and Brook & 1978 & Baringo basin- Kamasia Range & \\
\hline Kabarnet trachytes & & 7.1 & 7.3 & Ma & & & reported in Baker et al & 1971 & F.M. Consultants for GSK unpub & \\
\hline Kapkut volcano & & 7.4 & 7.8 & Ma & & & Chapman and Brook & 1978 & Baringo basin - Kamasia E. foothills, South of $0.5^{\circ}$ North & \\
\hline Olomorooj Phonolite & & 7.4 & & Ma & & & Crossley and Knight & 1981 & between $1^{\circ} 50^{\prime}$ and $1^{\circ} 30^{\prime} \mathrm{S}$ & \\
\hline Tasokwan trachyte & & 7.6 & & Ma & & & Chapman and Brook & 1978 & $\begin{array}{l}\text { Baringo basin - Laikipia escarpment, possibly equivalent to } \\
\text { Kabarnet trachyte }\end{array}$ & \\
\hline Pliocene basalts & & 8.31 & & Ma & & & reported in Baker et al & 1971 & S. Turkana, Gilbert (Patterson et. Al 1971) & \\
\hline Ewalel Phonolite & & 8.5 & 9.1 & Ma & & & Chapman and Brook & 1978 & Baringo basin- Kamasia Range & \\
\hline Tinderet Volcanics & & 8.9 & 9.4 & $\mathrm{Ma}$ & & & reported in Baker et al & 1971 & F.M. Consultants for GSK unpub & \\
\hline Nairobi phonolite & & 9.74 & 10.22 & Ma & & & Saggerson & 1991 & rock collected by Curtiss, Evernden and Miller. Feldspar K/Ar dated & 2 \\
\hline Tinderet Volcanics & & 9.9 & & Ma & & & reported in Baker et al & 1971 & Curtis (Bishop et al. 1969) & \\
\hline Rumuruti phonolite & & 10 & 11.9 & Ma & & & Chapman and Brook & 1978 & Baringo basin - Laikipia escarpment & \\
\hline Upper Rumuruti phonolites & & 11 & & Ma & & & reported in Baker et al & 1971 & Geochron lab. For Patterson, unpub & \\
\hline Microfoyaite Intrusion & & 11.6 & & Ma & & & Wilkinson & 1988 & Allia Bay area, N. Kenya, K/Ar dating, whole rock & \\
\hline Tiim Phonolites & & 11.7 & 13.5 & Ma & & & reported in Behrensmeyer et al. & 2002 & upper units- equivalent to the Uasin Gishu Phonolite & \\
\hline Kericho phonolites & & 11.8 & & Ma & & & reported in Baker et al & 1971 & Miller (Bishop et al. 1969) & \\
\hline Nakwele Formation & & 11.91 & & Ma & & & Key and Watkins & 1988 & Sabarei Area, N. Kenya & \\
\hline Kishalduga Frm & & 12 & & Ma & & & Crossley & 1979 & & 2 \\
\hline Upper Uaso Gishu phonolites & & 12 & & $\mathrm{Ma}$ & & & reported in Baker et al & 1971 & Miller (Bishop et al. 1969) & \\
\hline Lower Rumuruti phonolites & & 12 & & $\mathrm{Ma}$ & & & reported in Baker et al & 1971 & Geochron lab. For Patterson, unpub & \\
\hline
\end{tabular}


Age Date Compilation for the Kenya Rift

\begin{tabular}{|c|c|c|c|c|c|c|c|c|c|c|}
\hline Unit Name & Event & Age Min & Age Max & Age Units & Uncertainty & Method & Author & Year & Notes & $\begin{array}{c}\text { Quality } \\
\text { Assessment } \\
\end{array}$ \\
\hline Simbara Basalts & & 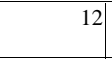 & & Ma & & & Smith & 1994 & $\begin{array}{l}\text { 12Ma is a miniumum age estimate. Smith claims that the age } \\
\text { published in Baker et al. } 1971 \text { was for a different unit entirely }\end{array}$ & 1 \\
\hline Tatesa Hills & & 12.1 & & Ma & & & Key and Watkins & 1988 & Basalt, Sabarei Area, N. Kenya & \\
\hline Kericho phonolites & & 12.1 & 13.4 & Ma & & & reported in Baker et al & 1971 & Miller (Bishop et al. 1969) & \\
\hline Kericho phonolites & & 12.3 & 12.4 & $\mathrm{Ma}$ & & & reported in Baker et al & 1971 & Miller (Bishop et al. 1969) & \\
\hline Lower Kisumu phonolites & & 12.3 & & Ma & & & reported in Baker et al & 1971 & Miller (Bishop et al. 1969) & \\
\hline Mimo phonolites & & 12.4 & & Ma & & & Ebinger et al. & 2000 & SW Ethiopia & \\
\hline Kericho phonolites & & 12.5 & 12.6 & Ma & & & reported in Baker et al & 1971 & Miller (Bishop et al. 1969) & \\
\hline Lodwar volcanics & & 12.5 & 14.9 & $\mathrm{Ma}$ & & & reported in Baker et al & 1971 & Grasty(Reilly et al. 1966) & \\
\hline Getra-Kele tephrite & & 12.7 & & Ma & & & Ebinger et al. & 2000 & SW Ethiopia & \\
\hline Kapiti phonolite & & 12.9 & 13.1 & Ma & & & reported in Baker et al & 1971 & Miller (Bishop et al. 1969) & 2 \\
\hline Gurro rhyolite & & 13 & & Ma & & & McDougall and Watkins & 2006 & Asille Group, NE of Turkana & \\
\hline Kisumu phonolites & & 13.1 & & Ma & & & reported in Baker et al & 1971 & Curtis (Bishop et al. 1969) & \\
\hline "Upper" Tiim Phonolites & & 13.12 & & Ma & & & Behrensmeyer and Deino et al. & 2002 & Baringo Area, Muruyur Type section, Ar/Ar date & \\
\hline Uasin Gishu phonolite & & 13.2 & 13.8 & $\mathrm{Ma}$ & & & Chapman and Brook & 1978 & Baringo basin- elgeyo escarpment & \\
\hline Yatta phonolite & & 13.2 & & Ma & & & reported in Baker et al & 1971 & Fairburn, 1963 & 2 \\
\hline Tiim Phonolites & & 13.24 & & Ma & & & reported in Behrensmeyer et al. & 2002 & a corrected date from Deino 1990 & \\
\hline Tiim Phonolites & & 13.3 & 15.3 & Ma & & & reported in Behrensmeyer et al. & 2002 & lower units- equivalent to the Uasin Gishu Phonolite & \\
\hline Muruyur Beds (top) & & 13.37 & & $\mathrm{Ma}$ & & & Behrensmeyer and Deino et al. & 2002 & Baringo Area, Muruyur Type section, $\mathrm{Ar} / \mathrm{Ar}$ date & \\
\hline Chew Bahir basalt & & 13.4 & & Ma & & & Ebinger et al. & 2000 & SW Ethiopia & \\
\hline Kapiti phonolite & & 13.4 & & Ma & & & reported in Baker et al & 1971 & Evernden and Curtis 1965 & 2 \\
\hline Lower Uasin Gishu phonolites & & 13.5 & 13.6 & $\mathrm{Ma}$ & & & reported in Baker et al & 1971 & Miller (Bishop et al. 1969) & \\
\hline Kumbi rhyolite & & 14 & & Ma & & & Ebinger et al. & 2000 & SW Ethiopia & \\
\hline Upper Turkana basalts & & 14 & & $\mathrm{Ma}$ & & & reported in Baker et al & 1971 & Geochron lab. For Patterson, unpub & \\
\hline fossiliferous tuffs, s. of Tinderet & & 14 & & $\mathrm{Ma}$ & & & reported in Baker et al & 1971 & Evernden and Curtis 1965 & \\
\hline fossiliferous tuffs, s. of Tinderet & & 14 & 14.7 & Ma & & & reported in Baker et al & 1971 & Miller (Bishop et al. 1969) & \\
\hline Weyto phonolite & & 14.1 & & Ma & & & Ebinger et al. & 2000 & SW Ethiopia & \\
\hline Samburu basalts & & 14.2 & & Ma & & & Chapman and Brook & 1978 & Baringo basin - Laikipia escarpment & \\
\hline Jibisa Porphyritic microsyenite & & 14.4 & & $\mathrm{Ma}$ & & & Key and Watkins & 1988 & Sabarei Area, N. Kenya & \\
\hline Chof phonolites & & 14.5 & 15.5 & Ma & & & Chapman and Brook & 1978 & Baringo basin- elgeyo escarpment & \\
\hline Kumbi rhyolite & & 14.5 & & Ma & & & Ebinger et al. & 2000 & SW Ethiopia & \\
\hline Kumbi rhyolite & & 14.6 & & Ma & & & Ebinger et al. & 2000 & SW Ethiopia & \\
\hline Kiahera series & & 14.6 & 15.9 & Ma & & & reported in Baker et al & 1971 & Evernden and Curtis 1965, (Everndam et al 1964) & \\
\hline Sidekh Phonolites & & 14.8 & & Ma & & & reported in Behrensmeyer et al. & 2002 & $\begin{array}{l}\text { corrected date of upper flow from Chapman and Brook 1978, } \\
\text { "Saimo phonolite" in Martin } 1969\end{array}$ & \\
\hline Kumbi rhyolitic tuff & & 14.9 & & Ma & & & Ebinger et al. & 2000 & SW Ethiopia & \\
\hline Elgeyo basalts & & 15.1 & 15.6 & Ma & & & reported in Baker et al & 1971 & F.M. Consultants for GSK unpub & \\
\hline Upper Elgon volcanics & & 15.1 & 15.5 & Ma & & & reported in Baker et al & 1971 & F.M. Consultants for GSK unpub & \\
\hline Kishalduga Frm & & 15.2 & & Ma & & & Crossley & 1979 & & 2 \\
\hline BPRP\#122 Tuff & & 15.35 & 15.45 & Ma & & & Behrensmeyer and Deino et al. & 2002 & "Baringo Paleontological Research Project" Tuff & \\
\hline Biryokwonin Tuff & & 15.55 & & Ma & & & Behrensmeyer and Deino et al. & 2002 & Baringo Area, BPRP \#89, Ar-Ar date & \\
\hline Biryokwonin Tuff & & 15.58 & & Ma & & & Behrensmeyer and Deino et al. & 2002 & Baringo Area, BPRP \#122, Ar-Ar date & \\
\hline Biryokwonin Tuff & & 15.62 & & Ma & & & Behrensmeyer and Deino et al. & 2002 & Baringo Area, BPRP \#89, Ar-Ar date & \\
\hline Muruyur Beds (base) & & 15.63 & & Ma & & & Behrensmeyer and Deino et al. & 2002 & Baringo Area, Muruyur Type section, Ar/Ar date & \\
\hline "Lower" Tiim Phonolites & & 15.8 & & Ma & & & Behrensmeyer and Deino et al. & 2002 & Baringo Area, BPRP \#89, Ar-Ar date & \\
\hline Asille Group & & 15.8 & 34.3 & Ma & & & McDougall and Watkins & 2006 & earliest magmatism of rift, tilted $6^{\circ} \mathrm{SSW}$ & \\
\hline Gum Dura Upper Rhyolites & & 15.8 & & Ma & & & McDougall and Watkins & 2006 & Asille Group, NE of Turkana & \\
\hline Turkana basalts & & 15.8 & & $\mathrm{Ma}$ & & & reported in Baker et al & 1971 & Geochron lab. For Patterson, unpub & \\
\hline "Lower" Tiim Phonolites & & 15.84 & & $\mathrm{Ma}$ & & & Behrensmeyer and Deino et al. & 2002 & Baringo Area, BPRP\#122, Ar-Ar date & \\
\hline BPRP \#89 bonebed Tuff & & 15.96 & & Ma & & & Behrensmeyer and Deino et al. & 2002 & "Baringo Paleontological Research Project" Tuff & \\
\hline
\end{tabular}


Age Date Compilation for the Kenya Rift

\begin{tabular}{|c|c|c|c|c|c|c|c|c|c|c|}
\hline Unit Name & Event & Age Min & Age Max & Age Units & Uncertainty & Method & Author & Year & Notes & $\begin{array}{c}\text { Quality } \\
\text { Assessment }\end{array}$ \\
\hline "Lower" Tiim Phonolites & & 15.98 & & $\mathrm{Ma}$ & & & Behrensmeyer and Deino et al. & 2002 & Baringo Area, Muruyur Type section, Ar/Ar date & \\
\hline Irile alkali basalts & & 16 & 20.6 & Ma & & & McDougall and Watkins & 2006 & Asille Group, NE of Turkana & \\
\hline Sabarei volcanics & & 16.2 & & Ma & & & Key and Watkins & 1988 & Ankaramitic basalt, Whole Rock, Sabarei Area, N. Kenya & \\
\hline Lunene lava & & 16.3 & 16.8 & Ma & & & reported in Baker et al & 1971 & Miller (Van Couvering and Miller, 1969) & \\
\hline Buluk Rhyolites & & 16.4 & & Ma & & & McDougall and Watkins & 2006 & Asille Group, NE of Turkana & \\
\hline Sidekh Phonolites & & 16.4 & & Ma & & & reported in Behrensmeyer et al. & 2002 & $\begin{array}{l}\text { corrected date of lower flow from Chapman and Brook 1978, } \\
\text { "Saimo phonolite" in Martin } 1969\end{array}$ & \\
\hline Lunene lava & & 16.5 & 16.6 & $\mathrm{Ma}$ & & & reported in Baker et al & 1971 & Miller (Van Couvering and Miller, 1969) & \\
\hline Weyto phonolite & & 16.7 & & Ma & & & Ebinger et al. & 2000 & SW Ethiopia & \\
\hline Turkana basalts & & 16.7 & & Ma & & & reported in Baker et al & 1971 & Geochron lab. For Patterson, unpub & \\
\hline Turkana basalts & & 16.8 & & Ma & & & reported in Baker et al & 1971 & Patterson et al. 1970 & \\
\hline Jarigole Phonolites & & 16.9 & & Ma & & & Wilkinson & 1988 & Allia Bay area, N. Kenya, K/Ar dating, whole rock & \\
\hline Basal Elgon volcanics & & 17.2 & 19.8 & Ma & & & reported in Baker et al & 1971 & Armstrong (Bishop et al. 1969) & \\
\hline lower Elgon volcanics & & 17.4 & & Ma & & & reported in Baker et al & 1971 & Armstrong (Walker et al. 1969) & \\
\hline Turkana basalts & & 17.5 & & Ma & & & reported in Baker et al & 1971 & Geochron lab. For Patterson, unpub & \\
\hline Samburu basalts & & 18.5 & 23 & Ma & & & reported in Baker et al & 1971 & F.M. Consultants for GSK unpub & \\
\hline Getra-Kele basalt & & 18.8 & & $\mathrm{Ma}$ & & & Ebinger et al. & 2000 & SW Ethiopia & \\
\hline Rangwa complex & & 19 & 19.3 & Ma & & & reported in Baker et al & 1971 & Miller (Bishop et al. 1969) & \\
\hline Teltele basalt & & 19.3 & & $\mathrm{Ma}$ & & & Ebinger et al. & 2000 & SW Ethiopia & \\
\hline Rusinga agglomerate group & & 19.5 & 19.6 & Ma & & & reported in Baker et al & 1971 & Miller (Van Couvering and Miller, 1969) & \\
\hline Koru beds (SW of tinderet) & & 19.5 & 19.6 & Ma & & & reported in Baker et al & 1971 & Miller (Bishop et al. 1969) & \\
\hline Koru beds (w. of Tinderet) & & 19.7 & 19.9 & Ma & & & reported in Baker et al & 1971 & Miller (Bishop et al. 1969) & \\
\hline Teltele basalt & & 20.2 & & Ma & & & Ebinger et al. & 2000 & SW Ethiopia & \\
\hline Samburu basalts & & 20.7 & & $\mathrm{Ma}$ & & & Chapman and Brook & 1978 & Baringo basin - Laikipia escarpment & \\
\hline Olo rhyolite & & 20.7 & & $\mathrm{Ma}$ & & & Ebinger et al. & 2000 & SW Ethiopia & \\
\hline Jibisa sodic granite & & 20.7 & & Ma & & & Key and Watkins & 1988 & Sabarei Area, N. Kenya & \\
\hline Turkana basalts & & 20.7 & 23 & Ma & & & reported in Baker et al & 1971 & Grasty(Reilly et al. 1966) & \\
\hline Kiahera series & & 21.7 & & Ma & & & reported in Baker et al & 1971 & Evernden and Curtis 1965 & \\
\hline Basal Elgon volcanics & & 21.9 & 22 & Ma & & & reported in Baker et al & 1971 & Miller (Walker et al. 1969) & \\
\hline Upper series, Karungu Lake & & 22.5 & & Ma & & & reported in Baker et al & 1971 & Miller (Bishop et al. 1969) & \\
\hline Teltele basalt & & 23 & & Ma & & & Ebinger et al. & 2000 & SW Ethiopia & \\
\hline Jarigole Phonolites & & 23.2 & & Ma & & & Wilkinson & 1988 & Allia Bay area, N. Kenya, K/Ar dating, whole rock & \\
\hline Upper Turkana basalts & & 23.3 & 23.5 & Ma & & & reported in Baker et al & 1971 & Grasty(Reilly et al. 1966) & \\
\hline Langaria Formation Rhyolites & & 26.8 & & $\mathrm{Ma}$ & & & McDougall and Watkins & 2006 & Asille Group, NE of Turkana & \\
\hline Nabwal transitional basalts & & 27.6 & 34.8 & $\mathrm{Ma}$ & & & McDougall and Watkins & 2006 & Asille Group, NE of Turkana & \\
\hline Turkana basalts & & 31.5 & 32.2 & Ma & & & reported in Baker et al & 1971 & Grasty(Reilly et al. 1966) & \\
\hline Balesa Koromto Basalts & & 35.2 & & Ma & & & Wilkinson & 1988 & Allia Bay area, N. Kenya, K/Ar dating, whole rock & \\
\hline Gamo-Amaro basalt & & 35.6 & & $\mathrm{Ma}$ & & & Ebinger et al. & 2000 & SW Ethiopia & \\
\hline Gamo-Amaro basalt & & 36.9 & & Ma & & & Ebinger et al. & 2000 & SW Ethiopia & \\
\hline Gamo-Amaro basalt & & 38.3 & & $\mathrm{Ma}$ & & & Ebinger et al. & 2000 & SW Ethiopia & \\
\hline Gamo-Amaro basalt & & 39.9 & & Ma & & & Ebinger et al. & 2000 & SW Ethiopia & \\
\hline Hamer basalt & & 95 & 151 & Ma & & & Ebinger et al. & 2000 & $\begin{array}{l}\text { *min age estimated from Ar-Ar step heating of whole rock, } \mathrm{SW} \\
\text { Ethiopia }\end{array}$ & \\
\hline Aluma basalt & & 97 & & Ma & & & Ebinger et al. & 2000 & SW Ethiopia, dike in metamorphic basement & \\
\hline Phlogopite crystals & & 480 & 530 & Ma & & & Saggerson & 1991 & indictaes last metamorphic event to affect basement & \\
\hline basement gneiss & & 510 & 522 & Ma & & & McDougall and Watkins & 2006 & K-Ar biotite cooling, Pan-African & \\
\hline
\end{tabular}


A. Guth, MS Thesis, 2007

\section{Appendix D: Volume Estimate Calculations}

\section{Description of the chart columns:}

Unite Name- Name of the geologic formation or unit

Measured Area-Surface area calculated from the digital files produce for mapping (i.e.

the exposed surface area of the unit at present)

Estimated Area- Probable original area of formation

Thickness- The formation thickness

Volume- Calculated from Measured Area and Thickness

Max Volume- Calculated from Estimated Area and Thickness

Thickness Source- Key to references used to obtain formation thickness

Estimated Area Source- In some cases probable formation extent has been verbally or visually described by authors. Unless specified otherwise, estimated areas were from conservative assumptions, such as the original flow must have at least had a perimeter that includes all outcrops.

\section{Sources}

11976 Baker and Mitchell,

22004 Otando, S.W.

31958 Baker x-section

41958 Baker report

51963 Baker S. Magadi x-section

61991 Randel KGA report,

*Geology of Suswa map x-section

71991 Saggerson Geology of Nairobi map *est from $\mathrm{x}$-section

81979 Crossley

91988 Baker, Mitchell and Williams

101993 Skilling

*minimum extimate from a drawing,

$* *$ thickness of $45 \mathrm{~m}$ used for max volume based on $50 \%$ being a $75 \mathrm{~m}$ unit in old caldera,
$* * *$ back calculated from given volume 11 estamated from DEM, probably a bare min.,

*-average height of 10 cinder cones,

volume of volcanic centers esimated as a cone

121981 Crossley and Knight

131991 Saggerson Geology KGS report

14 estimated extent based on current outcrops and landsat extrapolation,

*combo plp4+5

151966 Matheson, KGS

161966 Baker, Nyokie

172001 Mora et al.

182002 Behrensmeyer et al.

191994 Smith 
A. Guth, MS Thesis, 2007

Volume Estimate Calculations

\begin{tabular}{|c|c|c|c|c|c|c|c|}
\hline Unit Name & $\begin{array}{l}\text { Measured Area } \\
\quad(\text { sq Km) }\end{array}$ & $\begin{array}{c}\text { Estimated Area } \\
(\mathrm{sq} \mathrm{km})\end{array}$ & Thickness $(\mathrm{km})$ & $\begin{array}{l}\text { Volume (cu } \\
\qquad \mathrm{km})\end{array}$ & $\begin{array}{l}\text { Max Volume } \\
\text { (cu km) }\end{array}$ & $\begin{array}{l}\text { Thickness } \\
\text { Source }\end{array}$ & $\begin{array}{c}\text { Est. Area } \\
\text { Source }\end{array}$ \\
\hline Suswa10 & 5.84 & & 0.017 & 0.10 & & $10 * * *$ & \\
\hline $\begin{array}{l}\text { Suswa8-plp6 (OI } \\
\text { Doinyo Onyoke) }\end{array}$ & 95.70 & & 0.03 & 4.77 & & 6* & \\
\hline $\begin{array}{l}\text { Suswa6-plp4 } \\
\text { (Entarakua) }\end{array}$ & 46.43 & 157 & 0.015 & 0.70 & 7.07 & $10 * *$ & $14 *$ \\
\hline $\begin{array}{l}\text { Suswa7-plp5 } \\
\text { (Entarakua) }\end{array}$ & 19.15 & & 0.015 & 0.29 & & 10 & \\
\hline Suswa4-plt3 (Esinoni) & 31.31 & & 0.025 & 0.78 & & 10 & \\
\hline Suswa5-plp3, Oloolwa & 44.90 & 180 & 0.003 & 0.13 & 0.54 & $10 *$ & 14 \\
\hline Suswa Olgumi frm & & 95 & 0.014 & NA & 1.33 & 10 & 14 \\
\hline Suswa3-plt2 & 12.52 & & 0.002 & 0.03 & & 6 & \\
\hline Suswa1+2 (plp, plp2) & 79.63 & 640 & 0.03 & 2.39 & 6.40 & 10 & $14^{*}$ \\
\hline cinder cones & 11.90 & & 0.52 & 2.06 & & $11 *$ & \\
\hline Lengorale & 0.54 & & 0.03 & 0.02 & & 8 & \\
\hline Mau ash & 708.00 & 1105 & 0.304 & 215.23 & 335.92 & 6* & \\
\hline Mosiro basalt & 11.45 & & 0.011 & 0.13 & & 8 & \\
\hline $\begin{array}{c}\text { minor centers (e.g. } \\
\text { Nyokie) }\end{array}$ & 6.92 & & 0.2 & 0.46 & & 11 & \\
\hline minor ash & 34.28 & & 0.012 & 0.41 & & 16 & \\
\hline Gesumeti trachyte & 1.90 & 21.3 & 0.22 & 0.42 & 4.69 & 1 & \\
\hline Plateau trachyte & 1996.46 & 3172 & 0.15 & 299.47 & 475.80 & 1 & 14 \\
\hline Tepesi Basalt & 45.00 & 181 & 0.15 & 6.75 & 27.15 & 1 & \\
\hline Limuru pantellerite & 1.77 & 31 & 0.01 & 0.02 & 0.31 & 11 & \\
\hline N. Kordjya trachyte & 160.00 & 267 & 0.14 & 22.40 & 37.38 & 8 & \\
\hline Kordjya Basalt & 171.23 & 1281.23 & 0.15 & 25.68 & 192.18 & 8 & \\
\hline
\end{tabular}


A. Guth, MS Thesis, 2007

Volume Estimate Calculations

\begin{tabular}{|c|c|c|c|c|c|c|c|}
\hline Unit Name & $\begin{array}{c}\text { Measured Area } \\
(\mathrm{sq} \mathrm{Km})\end{array}$ & $\begin{array}{c}\text { Estimated Area } \\
(\mathrm{sq} \mathrm{km})\end{array}$ & Thickness $(\mathrm{km})$ & $\begin{array}{l}\text { Volume (cu } \\
\qquad \mathrm{km})\end{array}$ & $\begin{array}{l}\text { Max Volume } \\
(\mathrm{cu} \mathrm{km})\end{array}$ & $\begin{array}{l}\text { Thickness } \\
\text { Source }\end{array}$ & $\begin{array}{c}\text { Est. Area } \\
\text { Source }\end{array}$ \\
\hline Leshuta trachyte & 0.38 & & 0.01 & 0.00 & & 8 & \\
\hline Tepesi benmoreite & 29.52 & 134 & 0.15 & 4.43 & 20.10 & 1 & \\
\hline Gelai & 971.43 & 1312 & 1.93 & 624.95 & 844.05 & 11 & \\
\hline Limuru trachyte & 931.17 & 1874 & 0.3 & 279.35 & 562.20 & 1 & \\
\hline Sambu & 124.54 & 261 & 0.18 & 22.42 & 15.66 & 8 & 14 \\
\hline Ol Keju Nero & 1.66 & & 0.085 & 0.14 & & 1 & \\
\hline Ewaso Ngiro trachyte & 47.80 & 100 & 0.26 & 12.43 & 26.00 & 8 & \\
\hline Kabete trachyte & 59.80 & & 0.03 & 1.79 & & 13 & \\
\hline Karura trachyte & 36.10 & & 0.035 & 1.26 & & 7* & \\
\hline Shombole & 45.01 & 247 & 0.933 & 14.00 & 76.82 & 11 & 14 \\
\hline Tigoni trachyte & 43.90 & & 0.061 & 2.68 & & 13 & \\
\hline Mosiro trachyte & 260.41 & 1796 & 0.27 & 70.31 & 484.92 & 6* & 14 \\
\hline Singaraini basalt & 524.53 & 1500 & 0.457 & 239.71 & 685.50 & 5 & \\
\hline Lenderet & 60.49 & 290 & 0.3985 & 8.03 & 38.52 & 11 & \\
\hline Olorgesailie & 150.44 & 472 & 0.8022 & 40.23 & 126.21 & 11 & \\
\hline Kirikiti basalt & 101.10 & 2624 & 0.55 & 55.61 & 1443.20 & 8 & 14 \\
\hline Upper Kerichwa Tuff & 609.45 & 1725 & 0.04 & 24.38 & 69.00 & 13 & \\
\hline Nairobi trachyte & 241.60 & 1238 & 0.061 & 14.74 & 75.52 & 13,2 & 13 \\
\hline Sambu & 124.54 & & 0.4 & 49.82 & & 17 & \\
\hline Lower Kerichwa Tuff & 24.03 & 1133 & 0.006 & 0.14 & 6.80 & 13 & \\
\hline Narok agglomerate & 70.31 & 824 & 0.061 & 4.29 & 50.26 & 13 & \\
\hline Ngong hills & 156.59 & 310 & 0.5 & 26.10 & 155.00 & 11 & 13 \\
\hline Kiambu trachyte & 20.60 & 55.9 & 0.046 & 0.95 & 2.57 & 13 & 13 \\
\hline Nairobi phonolite & 329.00 & 573 & 0.04 & 13.16 & 22.92 & 13 & 13 \\
\hline Olorgesailie neph & 6.05 & & 0.15 & 0.91 & & 3 & \\
\hline $\begin{array}{l}\text { Olorgesailie neph- } \\
\text { phono }\end{array}$ & 60.83 & 230 & 0.06 & 3.65 & 13.80 & 15 & 14 \\
\hline
\end{tabular}


A. Guth, MS Thesis, 2007

Volume Estimate Calculations

\begin{tabular}{|c|c|c|c|c|c|c|c|}
\hline Unit Name & $\begin{array}{c}\text { Measured Area } \\
(\text { sq Km) }\end{array}$ & $\begin{array}{c}\text { Estimated Area } \\
(\mathrm{sq} \mathrm{km})\end{array}$ & Thickness (km) & $\begin{array}{l}\text { Volume (cu } \\
\mathrm{km} \text { ) }\end{array}$ & $\begin{array}{l}\text { Max Volume } \\
\text { (cu km) }\end{array}$ & $\begin{array}{c}\text { Thickness } \\
\text { Source }\end{array}$ & $\begin{array}{c}\text { Est. Area } \\
\text { Source }\end{array}$ \\
\hline Olorgesailie phono & 157.90 & 789 & 0.038 & 6.00 & 29.98 & 15 & 14 \\
\hline Esayeti & 112.72 & 316 & 0.363 & 13.64 & 38.24 & 11 & \\
\hline Lengitoto trachyte & 96.45 & 688 & 0.22 & 21.22 & 151.36 & 8 & 14 \\
\hline Kandizi phonolite & 9.97 & 103 & 0.015 & 0.15 & 1.54 & 11 & 13 \\
\hline Mbagathi trachyte & 178.00 & 504 & 0.061 & 10.86 & 30.74 & 13 & 13 \\
\hline Athi Tuff & 515.60 & 3022 & 0.305 & 157.26 & 921.71 & 7 & \\
\hline Simbara basalts & $\mathrm{NA}$ & 440 & 0.035 & $\mathrm{NA}$ & 15.40 & 7* & 13 \\
\hline Kapiti phonolite & 509.00 & 2182 & 0.06 & 30.54 & 130.92 & 15 & 13 \\
\hline $\begin{array}{c}\text { Melanephelinitic } \\
\text { (Kishalduga) }\end{array}$ & 159.12 & 1148 & 0.26 & 41.37 & 298.48 & 8 & 8 \\
\hline $\begin{array}{c}\text { Melanephelinitic } \\
\text { (Lisudwa) }\end{array}$ & 22.70 & 159 & 0.47 & 10.67 & 24.91 & 8 & 8 \\
\hline Plateau Phonolite & & 60748.4 & 0.7 & & 42523.88 & 18-est & 19 \\
\hline
\end{tabular}


A. Guth, MS Thesis, 2007

\section{Appendix E: Silica and Alkali Contents of South Kenya Rift Volcanics}

These data were used to make the composition charts seen alongside the paleomaps presented in this study. Some data were obtained for formations near the area mapped for this thesis and were included even though they are not represented by outcrops in the study area. If a formation was not located within the study area (In study area $=n$ ), then a note was made in the "relation to study area" column to denote where the formation can be found in relation to the study area.

Formations are first sorted by whether they appear within the study area or not, and are then sorted by age.

Sources can be seen below and also at the bottom of the table.

Sources:

1 Baker 1958

2 Baker 1975

3 Baker et al 1977

4 Crossley and Knight 1981

5 reported in GeoRoc, Bellieni et al. 1986 (8088)

6 reported in GeoRoc, Paslick et al. 1996 (7817)

7 reported in Gittins and Jago, 1998

8 reported in GeoRoc, Rogers et al. 2000, (7729)

9 reported in GeoRoc, Macdonald et al. 2001, (8029)

10 Le Roex et al. 2001

11 reported in Otando 2004 
A. Guth, MS Thesis, 2007

Composition of Rift Volcanics

\begin{tabular}{|c|c|c|c|c|c|c|c|c|c|}
\hline Unit name & $\mathrm{Na} 2 \mathrm{O}$ & $\mathrm{K} 2 \mathrm{O}$ & $\mathrm{SiO} 2$ & Total alkalis & source & sample \# & $\begin{array}{c}\text { age } \\
(\max )\end{array}$ & $\begin{array}{c}\text { In study } \\
\text { area }\end{array}$ & $\begin{array}{l}\text { Relation to } \\
\text { study area }\end{array}$ \\
\hline N. slope Suswa phonolite & 7.23 & 4.66 & 59.14 & 11.89 & $\overline{11}$ & & 0.24 & $\bar{y}$ & \\
\hline $\begin{array}{l}\text { compound dike } 2.6 \mathrm{~km} \mathrm{NW} \text { of Nyokie } \\
\text { summit } \\
\text { Nyokie ignimbrite }\end{array}$ & $\begin{array}{l}6.26 \\
6.29\end{array}$ & $\begin{array}{l}5.08 \\
5.20\end{array}$ & $\begin{array}{l}62.34 \\
61.93\end{array}$ & $\begin{array}{l}11.34 \\
11.49\end{array}$ & $\begin{array}{l}2 \\
2\end{array}$ & & $\begin{array}{l}0.60 \\
0.60\end{array}$ & $\begin{array}{l}\mathrm{y} \\
\mathrm{y}\end{array}$ & \\
\hline $\begin{array}{l}\text { Mosiro basalt } \\
\text { Mosiro basalt }\end{array}$ & $\begin{array}{l}0.78 \\
0.94\end{array}$ & $\begin{array}{l}2.91 \\
2.44\end{array}$ & $\begin{array}{l}47.82 \\
46.81\end{array}$ & $\begin{array}{l}3.69 \\
3.38\end{array}$ & $\begin{array}{l}4 \\
4\end{array}$ & $\begin{array}{l}48 \\
49\end{array}$ & $\begin{array}{l}0.60 \\
0.60\end{array}$ & $\begin{array}{l}y \\
y\end{array}$ & \\
\hline Mau Ash & 4.49 & 5.53 & 71.59 & 10.02 & 4 & 40 & 0.60 & $y$ & \\
\hline Magadi trachyte & 5.32 & 4.14 & 61.67 & 9.46 & 10 & KR015 & 1.40 & $y$ & \\
\hline Magadi trachyte & 5.76 & 5.02 & 61.35 & 10.78 & 10 & KR040 & 1.40 & $y$ & \\
\hline Magadi trachyte & 5.31 & 4.82 & 61.12 & 10.13 & 10 & KR042 & 1.40 & $y$ & \\
\hline Magadi Trachytes & 5.25 & 6.66 & 61.32 & 11.91 & 4 & 55 & 1.40 & $y$ & \\
\hline Magadi Trachytes & 5.21 & 6.73 & 61.89 & 11.94 & 4 & 56 & 1.40 & $y$ & \\
\hline Magadi Trachytes & 5.57 & 6.72 & 61.89 & 12.29 & 4 & 57 & 1.40 & $y$ & \\
\hline Magadi Trachytes & 5.51 & 6.87 & 61.65 & 12.38 & 4 & 58 & 1.40 & $y$ & \\
\hline Magadi Trachytes & 6.96 & 5.18 & 62.61 & 12.14 & 4 & 59 & 1.40 & $y$ & \\
\hline Magadi Trachytes & 6.46 & 5.14 & 61.23 & 11.60 & 4 & 60 & 1.40 & $y$ & \\
\hline Magadi Trachytes & 5.98 & 5.61 & 60.09 & 11.59 & 4 & 62 & 1.40 & $y$ & \\
\hline Magadi Trachytes & 6.39 & 4.92 & 62.55 & 11.31 & 4 & 63 & 1.40 & $y$ & \\
\hline Magadi Trachytes & 6.02 & 5.08 & 62.43 & 11.10 & 4 & 64 & 1.40 & $y$ & \\
\hline Magadi Trachytes & 5.99 & 5.21 & 61.87 & 11.20 & 4 & 65 & 1.40 & $y$ & \\
\hline Magadi Trachytes & 5.86 & 5.57 & 61.89 & 11.43 & 4 & 66 & 1.40 & $y$ & \\
\hline Magadi Trachytes & 6.03 & 5.06 & 65.15 & 11.09 & 4 & 67 & 1.40 & $y$ & \\
\hline Magadi Trachytes & 5.86 & 5 & 65.85 & 10.86 & 4 & 68 & 1.40 & $y$ & \\
\hline Magadi Trachytes & 6.92 & 4.5 & 60.25 & 11.42 & 4 & 69 & 1.40 & $y$ & \\
\hline Magadi Trachytes & 6.44 & 4.99 & 61.63 & 11.43 & 4 & 70 & 1.40 & $y$ & \\
\hline Magadi Trachytes & 6.33 & 5.59 & 64.02 & 11.92 & 4 & 71 & 1.40 & $y$ & \\
\hline Magadi Trachytes & 5.95 & 5.47 & 61.77 & 11.42 & 4 & 72 & 1.40 & y & \\
\hline Magadi Trachytes & 6.2 & 5.05 & 61.34 & 11.25 & 4 & 73 & 1.40 & $y$ & \\
\hline Plateau (Magadi) Trachyte & 6.11 & 5.23 & 62.76 & 11.34 & 3 & & 1.40 & $\mathrm{y}$ & \\
\hline Plateau (Magadi) Trachyte & 5.78 & 4.62 & 60.82 & 10.40 & 1 & & 1.40 & $y$ & \\
\hline
\end{tabular}


Composition of Rift Volcanics

\begin{tabular}{|c|c|c|c|c|c|c|c|c|c|}
\hline Unit name & $\mathrm{Na} 2 \mathrm{O}$ & $\mathrm{K} 2 \mathrm{O}$ & $\mathrm{SiO} 2$ & Total alkalis & source & sample \# & $\begin{array}{c}\text { age } \\
(\max )\end{array}$ & $\begin{array}{l}\text { In study } \\
\text { area }\end{array}$ & $\begin{array}{l}\text { Relation to } \\
\text { study area }\end{array}$ \\
\hline $\begin{array}{l}\text { Magadi Trachyte (magadi hospital) } \\
\text { Magadi Trachyte (NW and NE of } \\
\text { Olorgesailie) } \\
\text { Plateau (Magadi) trachyte (under east side } \\
\text { of Nyokie) }\end{array}$ & $\begin{array}{l}5.60 \\
6.07 \\
6.63\end{array}$ & $\begin{array}{l}5.01 \\
5.22 \\
5.01\end{array}$ & $\begin{array}{l}59.38 \\
61.87 \\
63.57\end{array}$ & $\begin{array}{l}10.61 \\
11.30 \\
11.64\end{array}$ & $\begin{array}{l}11 \\
2 \\
2\end{array}$ & & $\begin{array}{l}1.40 \\
1.40 \\
1.40\end{array}$ & $\begin{array}{l}\text { y } \\
\text { y } \\
\text { y }\end{array}$ & \\
\hline $\begin{array}{l}\text { Ol Tepesi basalt } \\
\text { Ol Tepesi basalt } \\
\text { Ol Tepesi basalt } \\
\text { Ol Tepesi basalt } \\
\text { Ol Tepesi Ferrobasalts } \\
\text { Ol Tepesi volcanics, alkaline basalt } \\
\text { Ol Tepesi volcanics, alkaline basalt }\end{array}$ & $\begin{array}{l}2.69 \\
3.12 \\
3.18 \\
3.03 \\
3.00 \\
2.83 \\
2.82\end{array}$ & $\begin{array}{l}0.78 \\
0.61 \\
0.57 \\
0.83 \\
1.18 \\
0.684 \\
1.038\end{array}$ & $\begin{array}{l}48.04 \\
46.86 \\
47.79 \\
46.05 \\
47.44 \\
47.13 \\
47.38\end{array}$ & $\begin{array}{l}3.47 \\
3.73 \\
3.75 \\
3.86 \\
4.18 \\
3.51 \\
3.86\end{array}$ & $\begin{array}{c}3 \\
10 \\
10 \\
10 \\
3 \\
8 \\
8\end{array}$ & $\begin{array}{l}\text { KR003 } \\
\text { KR004 } \\
\text { KR007 }\end{array}$ & $\begin{array}{l}1.42 \\
1.42 \\
1.42 \\
1.42 \\
1.42 \\
1.42 \\
1.42\end{array}$ & $\begin{array}{l}\text { y } \\
\text { y } \\
\text { y } \\
\text { y } \\
\text { y } \\
\text { y } \\
\text { y }\end{array}$ & \\
\hline $\begin{array}{l}\text { N. Kordjya trachyte } \\
\text { N. Kordjya trachyte }\end{array}$ & $\begin{array}{l}5.34 \\
5.26\end{array}$ & $\begin{array}{l}6.22 \\
6.14\end{array}$ & $\begin{array}{l}62.85 \\
61.59\end{array}$ & $\begin{array}{l}11.56 \\
11.40\end{array}$ & $\begin{array}{l}4 \\
4 \\
\end{array}$ & $\begin{array}{l}53 \\
54\end{array}$ & $\begin{array}{l}1.70 \\
1.70\end{array}$ & $\begin{array}{l}y \\
y\end{array}$ & \\
\hline OI Tepesi Benmoreites & 5.48 & 4.25 & 60.09 & 9.73 & 3 & & 1.81 & $y$ & \\
\hline $\begin{array}{l}\text { Ewaso Ngiro Trachyte } \\
\text { Ewaso Ngiro Trachyte } \\
\text { Ewaso Ngiro Trachyte }\end{array}$ & $\begin{array}{l}4.66 \\
4.88 \\
4.78 \\
\end{array}$ & $\begin{array}{c}6.01 \\
5.86 \\
5.8\end{array}$ & $\begin{array}{l}61.51 \\
62.65 \\
61.23\end{array}$ & $\begin{array}{l}10.67 \\
10.74 \\
10.58\end{array}$ & $\begin{array}{l}4 \\
4 \\
4\end{array}$ & $\begin{array}{l}50 \\
51 \\
52\end{array}$ & $\begin{array}{l}2.10 \\
2.10 \\
2.10\end{array}$ & $\begin{array}{l}\text { y } \\
\text { y } \\
y\end{array}$ & \\
\hline $\begin{array}{l}\text { Kordjya Basalt } \\
\text { Kordjya Basalt (CENTER WEST OF LISUDWA } \\
\text { Kordjya basalts } \\
\text { Kordjya basalts } \\
\text { Kordjya basalts } \\
\text { Kordjya basalts }\end{array}$ & $\begin{array}{l}2.73 \\
1.71 \\
0.68 \\
1.41 \\
0.95 \\
0.69\end{array}$ & $\begin{array}{l}0.66 \\
1.01 \\
2.93 \\
3.58 \\
2.89 \\
3.01\end{array}$ & $\begin{array}{c}47.63 \\
41.37 \\
48.1 \\
47.62 \\
48.03 \\
47.14\end{array}$ & $\begin{array}{l}3.39 \\
2.72 \\
3.61 \\
4.99 \\
3.84 \\
3.70\end{array}$ & $\begin{array}{l}9 \\
9 \\
4 \\
4 \\
4 \\
4\end{array}$ & $\begin{array}{l}44 \\
45 \\
46 \\
47\end{array}$ & $\begin{array}{l}2.20 \\
2.20 \\
2.20 \\
2.20 \\
2.20 \\
2.20\end{array}$ & $\begin{array}{l}\text { y } \\
\text { y } \\
\text { y } \\
\text { y } \\
\text { y } \\
\text { y }\end{array}$ & \\
\hline Seyabi Grey Tuff Bed & 5.71 & 5.78 & 61.53 & 11.49 & 4 & 39 & 2.20 & $y$ & \\
\hline $\begin{array}{l}\text { Mosiro trachytes } \\
\text { Mosiro trachytes } \\
\text { Mosiro trachytes }\end{array}$ & $\begin{array}{l}5.82 \\
5.72 \\
5.72\end{array}$ & $\begin{array}{l}5.26 \\
5.19 \\
5.28\end{array}$ & $\begin{array}{c}65.28 \\
64.56 \\
63.6\end{array}$ & $\begin{array}{l}11.08 \\
10.91 \\
11.00\end{array}$ & $\begin{array}{l}4 \\
4 \\
4\end{array}$ & $\begin{array}{l}41 \\
42 \\
43\end{array}$ & $\begin{array}{l}2.30 \\
2.30 \\
2.30\end{array}$ & $\begin{array}{l}y \\
y \\
y\end{array}$ & \\
\hline $\begin{array}{l}\text { Singaraini basalt } \\
\text { Singaraini basalt } \\
\text { Singaraini basalt } \\
\text { Singaraini basalt }\end{array}$ & $\begin{array}{l}2.97 \\
2.89 \\
3.27 \\
2.53\end{array}$ & $\begin{array}{l}0.52 \\
0.50 \\
0.68 \\
0.75\end{array}$ & $\begin{array}{l}47.38 \\
46.36 \\
47.81 \\
47.36\end{array}$ & $\begin{array}{l}3.49 \\
3.39 \\
3.95 \\
3.28\end{array}$ & $\begin{array}{c}10 \\
10 \\
10 \\
9\end{array}$ & $\begin{array}{l}\text { KR020 } \\
\text { KR022 } \\
\text { KR024 }\end{array}$ & $\begin{array}{l}2.30 \\
2.30 \\
2.30 \\
2.30\end{array}$ & $\begin{array}{l}y \\
y \\
y \\
y\end{array}$ & \\
\hline
\end{tabular}


Composition of Rift Volcanics

\begin{tabular}{|c|c|c|c|c|c|c|c|c|c|}
\hline Unit name & $\mathrm{Na} 2 \mathrm{O}$ & $\mathrm{K} 2 \mathrm{O}$ & $\mathrm{SiO} 2$ & Total alkalis & source & sample \# & $\begin{array}{l}\text { age } \\
(\max )\end{array}$ & $\begin{array}{l}\text { In study } \\
\text { area }\end{array}$ & $\begin{array}{l}\text { Relation to } \\
\text { study area }\end{array}$ \\
\hline Brown Tuff Unit, Olengoirenito valley & 5.22 & 4.9 & 56.09 & 10.12 & 4 & 38 & 2.70 & $y$ & \\
\hline $\begin{array}{l}\text { Lenderet Benmoreite } \\
\text { Lenderet Mugearite } \\
\text { Lenderet Mugearite } \\
\text { Lenderet Mugearite } \\
\text { Lenderet Mugearite } \\
\text { Lenderut Hawaiite } \\
\text { Lenderut Hawaiite }\end{array}$ & $\begin{array}{l}5.24 \\
5.36 \\
4.34 \\
4.49 \\
4.24 \\
4.08 \\
4.79\end{array}$ & $\begin{array}{l}2.79 \\
2.32 \\
1.95 \\
2.04 \\
2.10 \\
1.76 \\
1.97\end{array}$ & $\begin{array}{l}53.89 \\
48.72 \\
49.99 \\
50.26 \\
50.89 \\
48.05 \\
48.98\end{array}$ & $\begin{array}{l}8.03 \\
7.68 \\
6.29 \\
6.53 \\
6.34 \\
5.84 \\
6.76\end{array}$ & $\begin{array}{l}10 \\
10 \\
10 \\
10 \\
10 \\
10 \\
10\end{array}$ & $\begin{array}{l}\text { KR016 } \\
\text { KR009 } \\
\text { KR010 } \\
\text { KR011 } \\
\text { KR017 } \\
\text { KR008 } \\
\text { KR018 }\end{array}$ & $\begin{array}{l}2.70 \\
2.70 \\
2.70 \\
2.70 \\
2.70 \\
2.70 \\
2.70\end{array}$ & $\begin{array}{l}\text { y } \\
y \\
y \\
y \\
y \\
y \\
y\end{array}$ & \\
\hline $\begin{array}{l}\text { Olorgesailie } \\
\text { Olorgesailie }\end{array}$ & $\begin{array}{l}2.91 \\
2.36\end{array}$ & $\begin{array}{c}1.722 \\
1.19\end{array}$ & $\begin{array}{l}44.74 \\
43.01\end{array}$ & $\begin{array}{l}4.63 \\
3.55\end{array}$ & $\begin{array}{l}8 \\
9\end{array}$ & & $\begin{array}{l}2.70 \\
2.70\end{array}$ & $\begin{array}{l}\mathrm{y} \\
\mathrm{y}\end{array}$ & \\
\hline $\begin{array}{l}\text { Kirikiti basalt } \\
\text { Kirikiti basalt } \\
\text { Kirikiti basalt } \\
\text { Kirikiti basalt } \\
\text { Kirikiti basalt } \\
\text { Kirikiti basalt }\end{array}$ & $\begin{array}{l}2.40 \\
3.47 \\
2.57 \\
2.38 \\
3.05 \\
3.06\end{array}$ & $\begin{array}{l}0.50 \\
1.48 \\
0.54 \\
0.47 \\
0.61 \\
0.83\end{array}$ & $\begin{array}{l}46.16 \\
47.62 \\
47.18 \\
46.59 \\
47.76 \\
47.42\end{array}$ & $\begin{array}{l}2.90 \\
4.95 \\
3.11 \\
2.85 \\
3.66 \\
3.89\end{array}$ & $\begin{array}{l}10 \\
10 \\
10 \\
10 \\
10 \\
10\end{array}$ & $\begin{array}{l}\text { KR028 } \\
\text { KR030 } \\
\text { KR033 } \\
\text { KR034 } \\
\text { KR035 } \\
\text { KR038 }\end{array}$ & $\begin{array}{l}3.10 \\
3.10 \\
3.10 \\
3.10 \\
3.10 \\
3.10\end{array}$ & $\begin{array}{l}\text { y } \\
\text { y } \\
y \\
y \\
y \\
y\end{array}$ & \\
\hline $\begin{array}{l}\text { Sambu alkaline basalt } \\
\text { Sambu alkaline basalt } \\
\text { Sambu alkaline basalt } \\
\text { Sambu basanite } \\
\text { Sambu basanite } \\
\text { Sambu basanite } \\
\text { Sambu basanite }\end{array}$ & $\begin{array}{l}2.33 \\
3.55 \\
2.29 \\
2.73 \\
2.47 \\
3.62 \\
4.05\end{array}$ & $\begin{array}{c}0.74 \\
1.31 \\
0.85 \\
1.27 \\
1.3 \\
0.9 \\
1.78\end{array}$ & $\begin{array}{c}45.21 \\
47.18 \\
47.88 \\
44.47 \\
43.9 \\
41.92 \\
44.87 \\
\end{array}$ & $\begin{array}{l}3.07 \\
4.86 \\
3.14 \\
4.00 \\
3.77 \\
4.52 \\
5.83\end{array}$ & $\begin{array}{l}9 \\
9 \\
9 \\
9 \\
9 \\
9 \\
9\end{array}$ & & $\begin{array}{l}3.50 \\
3.50 \\
3.50 \\
3.50 \\
3.50 \\
3.50 \\
3.50\end{array}$ & $\begin{array}{l}\text { y } \\
y \\
y \\
y \\
y \\
y \\
y\end{array}$ & \\
\hline $\begin{array}{l}\text { Oletugathi Hawaiite } \\
\text { Oletugathi Hawaiite } \\
\text { Oletugathi Hawaiite }\end{array}$ & $\begin{array}{l}4.31 \\
4.15 \\
4.82\end{array}$ & $\begin{array}{l}2.4 \\
2.44 \\
2.5\end{array}$ & $\begin{array}{l}49.34 \\
49.55 \\
49.01\end{array}$ & $\begin{array}{l}6.71 \\
6.59 \\
7.32\end{array}$ & $\begin{array}{l}4 \\
4 \\
4\end{array}$ & $\begin{array}{l}32 \\
33 \\
34\end{array}$ & $\begin{array}{l}4.00 \\
4.00 \\
4.00\end{array}$ & $\begin{array}{l}\text { y } \\
\text { y } \\
\text { y }\end{array}$ & \\
\hline $\begin{array}{l}\text { Oletugathi series, Ewaso Ngiro series tuff } \\
\text { Oletugathi series, L. Entapot unit tuff } \\
\text { Oletugathi series, U. Entapot unit tuff }\end{array}$ & $\begin{array}{l}6.62 \\
5.37 \\
6.59\end{array}$ & $\begin{array}{c}4.89 \\
4.79 \\
4.9\end{array}$ & $\begin{array}{l}62.26 \\
67.42 \\
62.59\end{array}$ & $\begin{array}{l}11.51 \\
10.16 \\
11.49\end{array}$ & $\begin{array}{l}4 \\
4 \\
4\end{array}$ & $\begin{array}{l}37 \\
35 \\
36\end{array}$ & $\begin{array}{l}4.00 \\
4.00 \\
4.00\end{array}$ & $\begin{array}{l}y \\
y \\
y\end{array}$ & \\
\hline $\begin{array}{l}\text { Loisiumurto volcanics } \\
\text { Loisiumurto volcanics }\end{array}$ & $\begin{array}{c}2.5 \\
2.65\end{array}$ & $\begin{array}{l}0.83 \\
0.76\end{array}$ & $\begin{array}{l}40.79 \\
39.97\end{array}$ & $\begin{array}{l}3.33 \\
3.41\end{array}$ & $\begin{array}{l}4 \\
4\end{array}$ & $\begin{array}{l}14 \\
15\end{array}$ & $\begin{array}{l}4.20 \\
4.20\end{array}$ & $\begin{array}{l}\mathrm{y} \\
\mathrm{y}\end{array}$ & \\
\hline
\end{tabular}


Composition of Rift Volcanics

\begin{tabular}{|c|c|c|c|c|c|c|c|c|c|}
\hline Unit name & $\mathrm{Na} 2 \mathrm{O}$ & $\mathrm{K} 2 \mathrm{O}$ & $\mathrm{SiO} 2$ & Total alkalis & source & sample \# & $\begin{array}{c}\text { age } \\
(\max ) \\
\end{array}$ & $\begin{array}{c}\text { In study } \\
\text { area }\end{array}$ & $\begin{array}{l}\text { Relation to } \\
\text { study area }\end{array}$ \\
\hline Ngong Volcanic series, nephelinite & 4.95 & 2.02 & 41.95 & 6.97 & 9 & & 5.00 & $\mathrm{y}$ & \\
\hline Nairobi Phonolite & 7.53 & 5.69 & 56.56 & 13.22 & 11 & & 5.20 & $y$ & \\
\hline $\begin{array}{l}\text { Ol Esakut Phonolite (Esayeti complex) } \\
\text { Ol Esayeiti Basanite } \\
\text { Ol Esayeiti Basanite } \\
\text { Ol Esayeiti, basanite }\end{array}$ & $\begin{array}{l}9.00 \\
3.59 \\
4.18 \\
2.72 \\
\end{array}$ & $\begin{array}{l}5.45 \\
1.14 \\
0.82 \\
1.12 \\
\end{array}$ & $\begin{array}{l}49.62 \\
44.26 \\
44.17 \\
45.02 \\
\end{array}$ & $\begin{array}{c}14.45 \\
4.73 \\
5.00 \\
3.84 \\
\end{array}$ & $\begin{array}{c}11 \\
10 \\
10 \\
9 \\
\end{array}$ & $\begin{array}{l}\text { KR001 } \\
\text { KR002 }\end{array}$ & $\begin{array}{l}6.70 \\
6.70 \\
6.70 \\
6.70 \\
\end{array}$ & $\begin{array}{l}\text { y } \\
\text { y } \\
\text { y } \\
\text { y }\end{array}$ & \\
\hline $\begin{array}{l}\text { Lengitoto trachyte } \\
\text { Lengitoto trachyte } \\
\text { Lengitoto trachyte } \\
\text { Lengitoto trachyte } \\
\text { Lengitoto trachyte } \\
\text { Lengitoto trachyte } \\
\text { Lengitoto trachyte } \\
\text { Lengitoto trachyte }\end{array}$ & $\begin{array}{l}6.93 \\
6.85 \\
6.85 \\
7.63 \\
6.92 \\
7.21 \\
6.97 \\
5.92\end{array}$ & $\begin{array}{l}5.21 \\
5.09 \\
5.46 \\
5.43 \\
5.32 \\
5.38 \\
5.08 \\
5.22\end{array}$ & $\begin{array}{l}61.85 \\
61.93 \\
61.27 \\
61.82 \\
61.79 \\
61.56 \\
61.56 \\
62.27\end{array}$ & $\begin{array}{l}12.14 \\
11.94 \\
12.31 \\
13.06 \\
12.24 \\
12.59 \\
12.05 \\
11.14\end{array}$ & $\begin{array}{l}4 \\
4 \\
4 \\
4 \\
4 \\
4 \\
4 \\
4\end{array}$ & $\begin{array}{l}24 \\
25 \\
26 \\
27 \\
28 \\
29 \\
30 \\
31\end{array}$ & $\begin{array}{l}6.90 \\
6.90 \\
6.90 \\
6.90 \\
6.90 \\
6.90 \\
6.90 \\
6.90\end{array}$ & $\begin{array}{l}\text { y } \\
y \\
y \\
y \\
y \\
y \\
y \\
y\end{array}$ & \\
\hline Namutuakit volcanics & 7.78 & 5.42 & 50.07 & 13.20 & 4 & 17 & 6.90 & $y$ & \\
\hline $\begin{array}{l}\text { Lower Simbara Basalt, alkaline basalt } \\
\text { Lower Simbara Basalt, alkaline basalt } \\
\text { Lower Simbara Basalt, nephelinite }\end{array}$ & $\begin{array}{l}2.64 \\
2.31 \\
3.35\end{array}$ & $\begin{array}{l}0.706 \\
1.09 \\
1.35 \\
\end{array}$ & $\begin{array}{l}47.56 \\
45.01 \\
41.93 \\
\end{array}$ & $\begin{array}{l}3.35 \\
3.40 \\
4.70\end{array}$ & $\begin{array}{l}8 \\
9 \\
9\end{array}$ & & $\begin{array}{l}12.00 \\
12.00 \\
12.00 \\
\end{array}$ & $\begin{array}{l}y \\
y \\
y\end{array}$ & \\
\hline $\begin{array}{l}\text { Athi plains (Kapiti?) phonolite } \\
\text { Kapiti phonolite }\end{array}$ & $\begin{array}{l}7.63 \\
6.88\end{array}$ & $\begin{array}{l}5.13 \\
5.41\end{array}$ & $\begin{array}{l}57.94 \\
54.81\end{array}$ & $\begin{array}{l}12.76 \\
12.29\end{array}$ & $\begin{array}{l}11 \\
11\end{array}$ & & $\begin{array}{l}13.10 \\
13.10\end{array}$ & $\begin{array}{l}\mathrm{y} \\
\mathrm{y}\end{array}$ & \\
\hline $\begin{array}{l}\text { Kishalduga } \\
\text { Kishalduga } \\
\text { Kishalduga } \\
\text { Kishalduga }\end{array}$ & $\begin{array}{l}4.16 \\
2.68 \\
3.53 \\
3.54\end{array}$ & $\begin{array}{l}2.41 \\
3.01 \\
1.83 \\
2.05\end{array}$ & $\begin{array}{l}46.11 \\
46.29 \\
45.96 \\
47.39\end{array}$ & $\begin{array}{l}6.57 \\
5.69 \\
5.36 \\
5.59\end{array}$ & $\begin{array}{l}4 \\
4 \\
4 \\
4\end{array}$ & $\begin{array}{l}1 \\
2 \\
3 \\
4\end{array}$ & $\begin{array}{l}15.20 \\
15.20 \\
15.20 \\
15.20\end{array}$ & $\begin{array}{l}y \\
y \\
y \\
y\end{array}$ & \\
\hline
\end{tabular}


Composition of Rift Volcanics

\begin{tabular}{|c|c|c|c|c|c|c|c|c|c|}
\hline Unit name & $\mathrm{Na} 2 \mathrm{O}$ & $\mathrm{K} 2 \mathrm{O}$ & $\mathrm{SiO} 2$ & Total alkalis & source & sample \# & $\begin{array}{c}\text { age } \\
(\max )\end{array}$ & $\begin{array}{c}\text { In study } \\
\text { area }\end{array}$ & $\begin{array}{l}\text { Relation to } \\
\text { study area }\end{array}$ \\
\hline Kishalduga & 2.71 & 1.17 & 44.85 & 3.88 & 4 & 5 & 15.20 & $y$ & \\
\hline Kishalduga & 4.25 & 1.78 & 44.53 & 6.03 & 4 & 6 & 15.20 & $y$ & \\
\hline Kishalduga & 0.88 & 0.63 & 40.65 & 1.51 & 4 & 7 & 15.20 & $y$ & \\
\hline Kishalduga & 2.79 & 1.53 & 41.67 & 4.32 & 4 & 8 & 15.20 & $y$ & \\
\hline Kishalduga & 7.69 & 4 & 41.89 & 11.69 & 4 & 9 & 15.20 & $y$ & \\
\hline Kishalduga & 7.29 & 5.48 & 44.38 & 12.77 & 4 & 10 & 15.20 & $y$ & \\
\hline$\overline{\text { Lisudwa }}$ & 2.23 & 1.13 & 45.07 & 3.36 & 4 & 11 & 15.20 & $y$ & \\
\hline Lisudwa & 4.4 & 2.65 & 44.78 & 7.05 & 4 & 13 & 15.20 & $y$ & \\
\hline Lisudwa Volcanics, alkaline basalt & 2.21 & 1.172 & 44.84 & 3.38 & 8 & & 15.20 & $y$ & \\
\hline Lisudwa Volcanics, nephelinite & 1.57 & 0.66 & 44.08 & 2.23 & 9 & & 15.20 & $\mathrm{y}$ & \\
\hline alkali basalt, rogati river, Kikuyu & 2.63 & 0.94 & 43.50 & 3.57 & 11 & & & $y$ & \\
\hline Nephelinite (w. of Ngong) & 5.00 & 2.19 & 38.80 & 7.19 & 11 & & & $\mathrm{y}$ & \\
\hline
\end{tabular}

\begin{tabular}{|c|c|c|c|c|c|c|c|c|}
\hline Lengai natrocarbonatite & 31.79 & 8.51 & 0.19 & 40.30 & 7 & 0.00 & $\mathrm{n}$ & South \\
\hline Mosonik basanite & 4.19 & 1.7 & 41.93 & 5.89 & 6 & 2* & $\mathrm{n}$ & South \\
\hline Mosonik foidite & 8.43 & 2.7 & 43.7 & 11.13 & 6 & 2* & $\mathrm{n}$ & South \\
\hline Mosonik foidite & 12.17 & 6.16 & 43.53 & 18.33 & 6 & 2* & $\mathrm{n}$ & South \\
\hline Ngorongoro, basanite & 3.29 & 0.96 & 44.94 & 4.25 & 6 & 8* & $\mathrm{n}$ & South \\
\hline Ngorongoro, trachyte & 6.24 & 4.57 & 64.97 & 10.81 & 6 & 8* & $\mathrm{n}$ & South \\
\hline Pre-rift Second Cycle, alkaline basalt & 2.46 & 0.38 & 46.35 & 2.84 & 5 & 8.00 & $\mathrm{n}$ & North \\
\hline Pre-rift Second Cycle Volcanics, alkaline bas & 3.23 & 1 & 48.3 & 4.23 & 5 & 8.00 & $\mathrm{n}$ & North \\
\hline Pre-rift Second Cycle Volcanics, alkaline bas & 3.17 & 0.87 & 48.15 & 4.04 & 5 & 8.00 & $\mathrm{n}$ & North \\
\hline Pre-rift Second Cycle Volcanics, alkaline bas & 3.2 & 1.2 & 46.94 & 4.40 & 5 & 8.00 & $\mathrm{n}$ & North \\
\hline Pre-rift Second Cycle Volcanics, alkaline bas & 3.27 & 1.25 & 47.27 & 4.52 & 5 & 8.00 & $\mathrm{n}$ & North \\
\hline Pre-rift Second Cycle Volcanics, tholeiitic bas & 2.4 & 0.47 & 51.5 & 2.87 & 5 & 8.00 & $\mathrm{n}$ & North \\
\hline Pre-rift Second Cycle Volcanics, tholeiitic bas & 2.29 & 0.33 & 51.82 & 2.62 & 5 & 8.00 & $\mathrm{n}$ & North \\
\hline Pre-rift Second Cycle Volcanics, tholeiitic bas & 2.55 & 0.5 & 52.16 & 3.05 & 5 & 8.00 & $\mathrm{n}$ & North \\
\hline Pre-rift Second Cycle Volcanics, tholeiitic bas & 2.41 & 0.34 & 51.54 & 2.75 & 5 & 8.00 & $\mathrm{n}$ & North \\
\hline Pre-rift Second Cycle Volcanics, tholeiitic bas & 2.39 & 0.37 & 52.26 & 2.76 & 5 & 8.00 & $\mathrm{n}$ & North \\
\hline Pre-rift Second Cycle Volcanics, tholeiitic baf & 3.04 & 0.82 & 49.68 & 3.86 & 5 & 8.00 & $\mathrm{n}$ & North \\
\hline Pre-rift Second Cycle Volcanics, tholeiitic bas & 2.98 & 1 & 50.27 & 3.98 & 5 & 8.00 & $\mathrm{n}$ & North \\
\hline
\end{tabular}


Composition of Rift Volcanics

\begin{tabular}{|c|c|c|c|c|c|c|c|c|c|}
\hline Unit name & $\mathrm{Na} 2 \mathrm{O}$ & $\mathrm{K} 2 \mathrm{O}$ & $\mathrm{SiO} 2$ & Total alkalis & source & sample \# & $\begin{array}{c}\text { age } \\
(\max )\end{array}$ & $\begin{array}{c}\text { In study } \\
\text { area }\end{array}$ & $\begin{array}{l}\text { Relation to } \\
\text { study area }\end{array}$ \\
\hline Pre-rift Second Cycle Volcanics, tholeiitic bas & 3.05 & 1.05 & 51.56 & 4.10 & 5 & & 8.00 & $\bar{n}$ & North \\
\hline Pre-rift Second Cycle Volcanics, tholeiitic bas & 3.24 & 0.95 & 49.93 & 4.19 & 5 & & 8.00 & $\mathrm{n}$ & North \\
\hline Pre-rift Second Cycle Volcanics, tholeiitic bas & 2.93 & 1.11 & 51.55 & 4.04 & 5 & & 8.00 & $\mathrm{n}$ & North \\
\hline Pre-rift Second Cycle Volcanics, tholeiitic bas & 2.91 & 1.2 & 50.81 & 4.11 & 5 & & 8.00 & $\mathrm{n}$ & North \\
\hline Pre-rift Second Cycle Volcanics, tholeiitic bas & 3.05 & 1.11 & 50.69 & 4.16 & 5 & & 8.00 & $\mathrm{n}$ & North \\
\hline Pre-rift Second Cycle Volcanics, tholeiitic bas & 3.13 & 1.12 & 50.5 & 4.25 & 5 & & 8.00 & $\mathrm{n}$ & North \\
\hline Pre-rift Second Cycle Volcanics, tholeiitic bas & 3.04 & 1.23 & 50.79 & 4.27 & 5 & & 8.00 & $\mathrm{n}$ & North \\
\hline Pre-rift Second Cycle Volcanics, tholeiitic bas & 3.23 & 0.86 & 50.48 & 4.09 & 5 & & 8.00 & $\mathrm{n}$ & North \\
\hline Pre-rift Second Cycle Volcanics, tholeiitic bas & 3.07 & 1.12 & 50.46 & 4.19 & 5 & & 8.00 & $\mathrm{n}$ & North \\
\hline Pre-rift Second Cycle Volcanics, tholeiitic bas & 3.08 & 1.12 & 50.31 & 4.20 & 5 & & 8.00 & $\mathrm{n}$ & North \\
\hline Pre-rift Second Cycle Volcanics, tholeiitic bas & 3.01 & 1.25 & 51.46 & 4.26 & 5 & & 8.00 & $\mathrm{n}$ & North \\
\hline Pre-rift Second Cycle Volcanics, tholeiitic bas & 3.06 & 0.97 & 49.96 & 4.03 & 5 & & 8.00 & $\mathrm{n}$ & North \\
\hline Pre-rift Second Cycle Volcanics, tholeiitic bas & 3.06 & 1.05 & 49.85 & 4.11 & 5 & & 8.00 & $\mathrm{n}$ & North \\
\hline Pre-rift Second Cycle Volcanics, tholeiitic bas & 3.07 & 0.93 & 50.49 & 4.00 & 5 & & 8.00 & $\mathrm{n}$ & North \\
\hline Pre-rift Second Cycle Volcanics, tholeiitic bas & 2.91 & 1.11 & 50.49 & 4.02 & 5 & & 8.00 & $\mathrm{n}$ & North \\
\hline Pre-rift Second Cycle Volcanics, tholeiitic bas & 3.23 & 0.87 & 50.53 & 4.10 & 5 & & 8.00 & $\mathrm{n}$ & North \\
\hline Pre-rift Second Cycle Volcanics, transitional & 2.68 & 0.54 & 48.62 & 3.22 & 5 & & 8.00 & $\mathrm{n}$ & North \\
\hline Pre-rift First Cycle Volcanics, alkaline basalt & 2.85 & 0.7 & 46.19 & 3.55 & 5 & & 12.00 & $\mathrm{n}$ & North \\
\hline Pre-rift First Cycle Volcanics, alkaline basalt & 3.34 & 1.14 & 46.08 & 4.48 & 5 & & 12.00 & $\mathrm{n}$ & North \\
\hline Pre-rift First Cycle Volcanics, alkaline basalt & 3.02 & 1.08 & 45.07 & 4.10 & 5 & & 12.00 & $\mathrm{n}$ & North \\
\hline Pre-rift First Cycle Volcanics, alkaline basalt & 3.33 & 1.15 & 45.99 & 4.48 & 5 & & 12.00 & $\mathrm{n}$ & North \\
\hline Pre-rift First Cycle Volcanics, alkaline basalt & 2.9 & 0.54 & 47.79 & 3.44 & 5 & & 12.00 & $\mathrm{n}$ & North \\
\hline Pre-rift First Cycle Volcanics, alkaline basalt & 2.67 & 0.82 & 47.81 & 3.49 & 5 & & 12.00 & $\mathrm{n}$ & North \\
\hline Pre-rift First Cycle Volcanics, basanite & 3.61 & 1.14 & 45.03 & 4.75 & 5 & & 12.00 & $\mathrm{n}$ & North \\
\hline Pre-rift First Cycle Volcanics, basanite & 3.14 & 1.14 & 44.53 & 4.28 & 5 & & 12.00 & $\mathrm{n}$ & North \\
\hline Pre-rift First Cycle Volcanics, basanite & 3.36 & 1.15 & 45.15 & 4.51 & 5 & & 12.00 & $\mathrm{n}$ & North \\
\hline Pre-rift First Cycle Volcanics, basanite & 3.07 & 1.19 & 45.02 & 4.26 & 5 & & 12.00 & $\mathrm{n}$ & North \\
\hline Pre-rift First Cycle Volcanics, tholeiitic basalt & 2.59 & 0.49 & 50.02 & 3.08 & 5 & & 12.00 & $\mathrm{n}$ & North \\
\hline Pre-rift First Cycle, tholeiitic basalt & 2.35 & 0.36 & 50.4 & 2.71 & 5 & & 12.00 & $\mathrm{n}$ & North \\
\hline Pre-rift First Cycle, tholeiitic basalt & 2.61 & 0.38 & 50.88 & 2.99 & 5 & & 12.00 & $\mathrm{n}$ & North \\
\hline Pre-rift First Cycle, tholeiitic basalt & 2.59 & 0.35 & 51.22 & 2.94 & 5 & & 12.00 & $\mathrm{n}$ & North \\
\hline
\end{tabular}


Composition of Rift Volcanics

\begin{tabular}{|c|c|c|c|c|c|c|c|c|c|}
\hline Unit name & $\mathrm{Na} 2 \mathrm{O}$ & $\mathrm{K} 2 \mathrm{O}$ & $\mathrm{SiO} 2$ & Total alkalis & source & sample \# & $\begin{array}{c}\text { age } \\
(\max ) \\
\end{array}$ & $\begin{array}{c}\text { In study } \\
\text { area }\end{array}$ & $\begin{array}{l}\text { Relation to } \\
\text { study area }\end{array}$ \\
\hline Pre-rift First Cycle, tholeiitic basalt & 2.56 & 0.41 & 49.91 & 2.97 & 5 & & 12.00 & $\mathrm{n}$ & North \\
\hline Pre-rift First Cycle, transitional basalt & 2.82 & 0.5 & 48.77 & 3.32 & 5 & & 12.00 & $\mathrm{n}$ & North \\
\hline Pre-rift First Cycle, transitional basalt & 2.73 & 0.77 & 49.74 & 3.50 & 5 & & 12.00 & $\mathrm{n}$ & North \\
\hline Pre-rift First Cycle, transitional basalt & 2.72 & 0.52 & 48.15 & 3.24 & 5 & & 12.00 & $\mathrm{n}$ & North \\
\hline Basanite (Aberdare range) & 2.74 & 1.42 & 45.65 & 4.16 & 11 & & & $\mathrm{n}$ & North \\
\hline Nyeri Hill phonolite & 7.54 & 4.85 & 57.05 & 12.39 & 11 & & & $\mathrm{n}$ & North \\
\hline
\end{tabular}

* age estimated

\section{Baker 1958}

2 Baker 1975

3 Baker et al 1977

4 Crossley and Knight 1981

5 reported in GeoRoc, Bellieni et al. 1986 (8088)

6 reported in GeoRoc, Paslick et al. 1996 (7817)

7 reported in Gittins and Jago, 1998

8 reported in GeoRoc, Rogers et al. 2000, (7729)

9 reported in GeoRoc, Macdonald et al. 2001, (8029)

10 Le Roex et al. 2001

11 reported in Otando 2004 
A. Guth, MS Thesis, 2007

\section{Appendix F: Geologic Map for the Southern Kenya Rift}

The electronic map file produced for this study is available on the accompanying CD.

File name: KenyaMap.pdf

File size (digital): $178 \mathrm{MB}$

Map size: 31 inches $(78.74 \mathrm{~cm})$ wide x 36 inches $(91.44 \mathrm{~cm})$ long

A printed version of the map is also available in the back pocket of this thesis. 
A. Guth, MS Thesis, 2007

\section{Appendix G: Volcanic Gas Estimates}

Presented here are some rough estimates of the amount of carbon that could be derived from a magma body degassing under then rift valley floor. Several authors have made estimates as to the size of the magma body, the initial amount of $\mathrm{CO}_{2}$ and the amount that can potentially be degassed at depth. Using these estimates the goal was to see if such a magma body degassing could account for the carbon locked up as carbonate in the Lake Magadi trona deposit. 
A. Guth, MS Thesis, $2007 \quad$ Appendix G: Volcanic Gas Estimates

\begin{tabular}{|c|}
\hline Length of Magadi Basin $(\mathrm{km})$ \\
35.5 \\
\hline
\end{tabular}

\begin{tabular}{|r|l}
\hline Dyke zone width $(\mathrm{km})$ & Macdonald 2003 \\
2.7 & $30 \%$ max dikes from Keranen et. Al, 2004
\end{tabular}

\begin{tabular}{|c|}
\hline Dyke zone depth $(\mathrm{km})$ \\
10 \\
\hline
\end{tabular}

based on Gerlach, that degassing happens at depths less than $11 \mathrm{~km} .10 \mathrm{~km}$ is used in the calculation as magma is not present at the surface

Volume magma under Magadi Basin (cubic km)

958.5

Density of basalt melt $(\mathrm{kg} / \mathrm{km} 3)$

2.7E+12

Density of basalt $(\mathrm{kg} / \mathrm{m} 3)$

2700

CO2 content of magma (wt \%)

0.1

CO2 content of magma (decimal wt \%) 0.001

Basalt density from

(http://www.nsm. buffalo.edu/ courses/gly431/431studyl_01. html)

\section{Magma under Magadi $(\mathrm{kg})$ \\ $2.59 \mathrm{E}+15$}

Potential Mass CO2 under Magadi (kg)

$2.59 \mathrm{E}+12$

Moles of $\mathrm{CO} 2$

$5.88 \mathrm{E}+13$

Moles Carbon

$5.88 \mathrm{E}+13$

\begin{tabular}{|c|l|l|l|}
\hline Trona Area $(\mathrm{m} 2)$ & $\begin{array}{l}\text { Average Trona } \\
\text { Thickness }(\mathrm{m})\end{array}$ & $\begin{array}{l}\text { Trona Volume } \\
(\mathrm{m} 3)\end{array}$ & $\begin{array}{l}\text { Trona Mass } \\
(\mathrm{kg})\end{array}$ \\
\hline 77700000 & 25 & 1942500000 & $4.14 \mathrm{E}+12$ \\
\hline
\end{tabular}

Moles Trona

$1.83 \mathrm{E}+13$

Moles Carbon in Trona

$3.66 \mathrm{E}+13$

Potential Magma derived

Moles Carbon - Moles

Carbon locked in Trona

$2.22 \mathrm{E}+13$ 
A. Guth, MS Thesis, 2007

\section{Appendix H: Microbiology of Lake Magadi}

\section{Description of the chart columns:}

Type: Higher-order classification

Genus-Species: Genus and species classification (Note comments below)

Age $(\mathrm{ka})$ : Some of the names provided here are for microbes found in the geologic

record that got preserved in sediments around the lake. Age is included to help

discriminate between modern and ancient species.

Author and Year: Source that listed the species as living in Magadi.

Notes:

*CyanoDB claims Cyanospira is synonomous with Anabaena

* But, Iteman et al. (2002) shows high similarity in rDNA between Anabaenopsis and

Cyanospira and they might be combined into a single genus

** published as "Tindallia magadii", but name was corrected to magadiensis in 1999 by Int. J .

Syst. Bacteriol., vol 49, pg 1-3

+published as Natronoincola, "'"

$* * *$ originally Natronobacterium

++ originally Natrobacterium

Classifications obtained from "Catalogue of Life" <http://www.catalogueoflife.org/ > J une 22, 2007, when not given specifically by the reference otherwise listed. 


\begin{tabular}{|c|c|c|c|c|c|}
\hline & Phylum & Genus-Species & Age & Author & Year \\
\hline \multirow{21}{*}{ 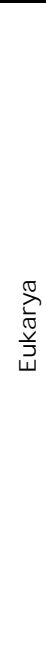 } & Bacillariophyta (Diatoms) & Anomoeoneis & $18-17 \mathrm{ka}$ & Barker et al. & 1990 \\
\hline & Bacillariophyta (Diatoms) & Anomoeoneis & $12.5-10 \mathrm{ka}$ & Barker et al. & 1990 \\
\hline & Bacillariophyta (Diatoms) & Anomoeoneis sphaerophora & recent & Barker et al. & 1990 \\
\hline & Bacillariophyta (Diatoms) & Aulacoseira & $17-12.5 \mathrm{ka}$ & Barker et al. & 1990 \\
\hline & Bacillariophyta (Diatoms) & Cyclotella & $17-12.5 \mathrm{ka}$ & Barker et al. & 1990 \\
\hline & Bacillariophyta (Diatoms) & Cyclotella & $780-300 \mathrm{ka}$ & Behr and Rohricht & 2000 \\
\hline & Bacillariophyta (Diatoms) & Epithemia & $17-12.5 \mathrm{ka}$ & Barker et al. & 1990 \\
\hline & Bacillariophyta (Diatoms) & Fragilaria & $17-12.5 \mathrm{ka}$ & Barker et al. & 1990 \\
\hline & Bacillariophyta (Diatoms) & Hantzschia & $18-17 \mathrm{ka}$ & Barker et al. & 1990 \\
\hline & Bacillariophyta (Diatoms) & Navicula & $18-17 \mathrm{ka}$ & Barker et al. & 1990 \\
\hline & Bacillariophyta (Diatoms) & Navicula & $17-12.5 \mathrm{ka}$ & Barker et al. & 1990 \\
\hline & Bacillariophyta (Diatoms) & Navicula & $12.5-10 \mathrm{ka}$ & Barker et al. & 1990 \\
\hline & Bacillariophyta (Diatoms) & Navicula & $98 \mathrm{ka}$ & Behr and Rohricht & 2000 \\
\hline & Bacillariophyta (Diatoms) & Navicula gawaniensis & recent & Barker et al. & 1990 \\
\hline & Bacillariophyta (Diatoms) & Nitzschia & $18-17 \mathrm{ka}$ & Barker et al. & 1990 \\
\hline & Bacillariophyta (Diatoms) & Nitzschia & $12.5-10 \mathrm{ka}$ & Barker et al. & 1990 \\
\hline & Bacillariophyta (Diatoms) & Rhopalodia & $18-17 \mathrm{ka}$ & Barker et al. & 1990 \\
\hline & Bacillariophyta (Diatoms) & Rhopalodia & $17-12.5 \mathrm{ka}$ & Barker et al. & 1990 \\
\hline & Bacillariophyta (Diatoms) & Stephanodiscus & $17-12.5 \mathrm{ka}$ & Barker et al. & 1990 \\
\hline & Bacillariophyta (Diatoms) & Thalassiosira & $17-12.5 \mathrm{ka}$ & Barker et al. & 1990 \\
\hline & Chlorophyta (green algae) & Chlorella minutissima & recent & reported in Baumgarte & 2003 \\
\hline \multirow{32}{*}{ 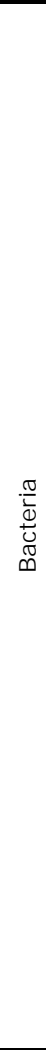 } & Actinobacteria & Micrococcus & $98 \mathrm{ka}$ & Behr and Rohricht & 2000 \\
\hline & Actinobacteria & Micromonospora & $98 \mathrm{ka}$ & Behr and Rohricht & 2000 \\
\hline & Cyanobacteria & Aphanothece & recent & Dubinin et al. & 1995 \\
\hline & Cyanobacteria & Chamaesiphon & recent & Dubinin et al. & 1995 \\
\hline & Cyanobacteria & Chroococcus & $98 \mathrm{ka}$ & Behr and Rohricht & 2000 \\
\hline & Cyanobacteria & Cyanospira* capsulatus & recent & Florenzano et al. & 1985 \\
\hline & Cyanobacteria & Cyanospira* ripkae & recent & Florenzano et al. & 1985 \\
\hline & Cyanobacteria & Entophysalis & $98 \mathrm{ka}$ & Behr and Rohricht & 2000 \\
\hline & Cyanobacteria & Gloecocapsa & $98 \mathrm{ka}$ & Behr and Rohricht & 2000 \\
\hline & Cyanobacteria & Microcoleus & $98 \mathrm{ka}$ & Behr and Rohricht & 2000 \\
\hline & Cyanobacteria & Oscillatoria & recent & Dubinin et al. & 1995 \\
\hline & Cyanobacteria & Phormidium & recent & Dubinin et al. & 1995 \\
\hline & Cyanobacteria & Phormidium & $98 \mathrm{ka}$ & Behr and Rohricht & 2000 \\
\hline & Cyanobacteria & Pleurocapsa & $98 \mathrm{ka}$ & Behr and Rohricht & 2000 \\
\hline & Cyanobacteria & Rhabdoderma & recent & Dubinin et al. & 1995 \\
\hline & Cyanobacteria & Schizothrix & $98 \mathrm{ka}$ & Behr and Rohricht & 2000 \\
\hline & Cyanobacteria & Spirulina & recent & Dubinin et al. & 1995 \\
\hline & Cyanobacteria & Spirulina platensis (see note) & recent & $\begin{array}{l}\text { Reported in Florenzano et } \\
\text { al. }\end{array}$ & 1985 \\
\hline & Cyanobacteria & Synechococcus & recent & Dubinin et al. & 1995 \\
\hline & Cyanobacteria & Synechococcus & $98 \mathrm{ka}$ & Behr and Rohricht & 2000 \\
\hline & Cyanobacteria & Synechocystis & recent & Dubinin et al. & 1995 \\
\hline & Firmicutes: Bacilli & Amphibacillus fermentum & recent & Zhilina et al. (b) & 2001 \\
\hline & Firmicutes: Bacilli & Amphibacillus tropicus & recent & Zhilina et al. (b) & 2001 \\
\hline & Firmicutes: Clostridia & Natronincola+ histidinovorans & recent & Zhilina et al. & 1998 \\
\hline & Firmicutes: Clostridia & Tindallia magadiensis** & recent & Kevbrin et al. & 1998 \\
\hline & Proteobacteria & Ectothiorhodospira & recent & Zhilina et al. & 1998 \\
\hline & Proteobacteria & Halomonas campisalis & recent & Boltyanskaya et al. & 2004 \\
\hline & Proteobacteria & Halomonas magadii & recent & $\begin{array}{l}\text { reported in Bhatnagar and } \\
\text { Bhatnagar }\end{array}$ & 2005 \\
\hline & Proteobacteria & Halorhodospira & recent & reported in Grant et al. & 1999 \\
\hline & Proteobacteria & Hyphomicrobium & $98 \mathrm{ka}$ & Behr and Rohricht & 2000 \\
\hline & Spirochaetes & Spirochaeta africana & recent & Zhilina et al. & 1996 \\
\hline & Spirochaetes & Spirochaeta alkalica & recent & Zhilina et al. & 1996 \\
\hline \multirow{4}{*}{ 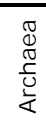 } & Halobacteroidaceae & Halonatronum saccharophilum & recent & Zhilina et al. (a) & 2001 \\
\hline & Halobacteroidaceae & Natronomonas*** & recent & reported in Grant et al. & 1999 \\
\hline & Halobacteroidaceae & Natronococcus & recent & reported in Grant et al. & 1999 \\
\hline & Halobacteroidaceae & Natrialba++ magadii & recent & reported in Grant et al. & 1999 \\
\hline
\end{tabular}

Note: noted in East African alkaline lakes in general 